UNIVERSIDADE DE SÃO PAULO

Faculdade de Zootecnia e Engenharia de Alimentos

Departamento de Engenharia de Alimentos

\title{
Utilização de solvente biorenovável nos processos de extração e desacidificação de óleos vegetais
}

Profa. Dra. Christianne Elisabete da Costa Rodrigues

Pirassununga - SP

2011 
Profa. Dra. Christianne Elisabete da Costa Rodrigues

\section{Utilização de solvente biorenovável nos processos de extração e desacidificação de óleos vegetais}

Tese apresentada à Faculdade de Zootecnia e Engenharia de Alimentos da Universidade de São Paulo, como parte das exigências do concurso para obtenção do título de LivreDocente, na área de "Equilíbrio de Fases e Processos de Separação na Indústria de Alimentos”.

Pirassununga - SP

2011 
Dados Internacionais de Catalogação na Publicação

Serviço de Biblioteca e Informação da Faculdade de Zootecnia e Engenharia de Alimentos da Universidade de São Paulo

R696u

Rodrigues, Christianne Elisabete da Costa

Utilização de solvente biorenovável nos processos de extração e desacidificação de óleos vegetais /

Christianne Elisabete da Costa Rodrigues. --

Pirassununga, 2011.

$171 \mathrm{f}$.

Tese (Livre Docência) - Faculdade de Zootecnia e Engenharia de Alimentos - Universidade de São Paulo. Departamento de Engenharia de Alimentos.

Área de Concentração: Equilíbrio de Fases e Processos de Separação na Indústria de Alimentos.

1. Extração sólido-líquido 2. Extração líquidolíquido 3. Etanol 4. Óleo de farelo de arroz 5. Óleo de soja 6. UNIQUAC. I. Título. 
"O que importa na vida não é a ponto de partida, mas a caminhada. Caminhando e semeando, no fim terás o que colther!" (Cora Coralina - 1889-1985)

Edson e Thiago, com amor! Dedico a vocês a realização deste trabalho. 


\section{"Q satisfação está no esforço feito para alcançar o objetivo, e não em tê-lo alcançado." OTahatma Sanahi (1869 - 1948)}

Agradeço a Deus pela vida, saúde, oportunidades, força, paciência, perseverança, pela minha família, por tudo!

Agradeço a toda minha família pelo incentivo e carinho!

Agradeço aos alunos dos cursos de graduação e pós-graduação em Engenharia de Alimentos da FZEA/USP por terem feito / por fazerem parte da minha vida. Obrigada pela oportunidade de ensinar!

Em ordem cronológica: Maitê Sarria Cuevas, Ramon Oliveira Beatriz, Fernanda Nóbrega de Abreu, Juliana Bonini Lopes, Bruna Rafaela Garavazo, Natalia Menegasso Longo, Vinícius Oliveira Beatriz, Cibele de Castro Silva, Poliana da Silva Arruda, Cristina Chiyoda Koshima, Maria Carolina Capellini, Cássia Maria de Oliveira, Juliane Akemi Araújo de Melo Kamimura, Tatiane Akemi Toda, Fernanda Hortense de Carvalho, Mirian Megumi Sawada, Daniel Gonçalves, Marcela Moreira, Larissa Lopes Venâncio.

Agradeço a Keila Kazue Aracava por sua disponibilidade e participação ativa em todos os trabalhos de pesquisa que são desenvolvidos no Laboratório de Engenharia de Separações, mas, principalmente, agradeço pela sua amizade!

Agradeço a amiga de longa data Cintia Bernardo Gonçalves, pela presença, companheirismo, amizade e por termos realizado o sonho de construir o Laboratório de Engenharia de Separações!

Agradeço a amiga Giovana Tommaso, pela amizade, generosidade e por termos compartilhado os momentos bons e ruins desta empreitada!

Agradeço a amiga Rosemary Carvalho, pela presença, amizade, disponibilidade, incentivo e por ter tido paciência de ler esta tese! 
Agradeço a todos os Professores da FZEA, em especial Paulo José do Amaral Sobral, Carlos Augusto Fernandes de Oliveira, Carmen Silvia Fávaro Trindade, Eliana Kamimura, Flávio Vieira Meirelles, Holmer Savastano Jr., Raul Franzolin Neto, Catarina Gomide, Elisabete Viegas, Ana Lúcia Gabas, Walter Velloso Jr., Gelson Conceição, pelo incentivo!

Agradeço a todos os Professores do ZEA, em especial Rose, Cintia, Giovana, Carmen, Marco Antonio, Mônica, Alessandra, Eliana, Maria Teresa, Rodrigo, Fernando, Samantha, Rogers, Gustavo, Cynthia, pelos bons momentos de descontração!

Agradeço a toda comunidade da FZEA/USP, professores, alunos e funcionários por, através de diferentes formas, ajudarem a realizar este trabalho!

Agradeço ao Prof. Dr. Antonio José de Almeida Meirelles da FEA/UNICAMP, pela amizade, confiança e ensinamentos, desde o início de meu doutoramento!

Agradeço aos Professores da FEQ/UNICAMP Flávio Vasconcelos da Silva e Ana Maria Frattini Fileti pelo apoio dado na implantação da disciplina de Controle de Processos na FZEA/USP.

Agradeço à FAPESP pelo fomento à pesquisa o qual possibilitou a montagem e manutenção do Laboratório de Engenharia de Separações na FZEA/USP.

Agradeço à FAPESP e ao CNPq pelas bolsas concedidas aos alunos de graduação e pós-graduação que desenvolvem seus trabalhos no Laboratório de Engenharia de Separações na FZEA/USP.

Agradeço às indústrias Irgovel/NutraCea, Granol e Cargill pelas doações de farelo de arroz, soja laminada, soja expandida e óleos de farelo de arroz, soja e girassol. 
RODRIGUES, C. E. C. Utilização de solvente biorenovável nos processos de extração e desacidificação de óleos vegetais. 2011. 171 f. Tese (Livre Docência) - Faculdade de Zootecnia e Engenharia de Alimentos, Universidade de São Paulo, Pirassuninga, 2011.

\section{Resumo}

O objetivo principal desta tese de livre docência foi estudar a viabilidade técnica do emprego de solventes alcoólicos, como substitutos do hexano, no processo de extração de óleos vegetais de matrizes sólidas. A utilização do etanol apresenta vantagens bastante atrativas do ponto de vista ambiental, uma vez que este é produzido por via biotecnológica, não gera resíduos tóxicos, apresenta menor grau de inflamabilidade e é considerado seguro para a saúde humana. Vantagens do ponto de vista econômico também são evidentes, uma vez que o etanol é produzido em larga escala no Brasil e pode ser facilmente recuperado, para posterior reutilização no processo. Neste trabalho de pesquisa duas matérias-primas oleaginosas foram estudadas, soja laminada e farelo de arroz em pellets. Na primeira etapa deste trabalho, foi realizado extenso estudo do equilíbrio sólido-líquido através da execução de quatro tipos de planejamentos de experimentos nos quais as variáveis independentes foram a temperatura (faixa de variação de 40 a $90{ }^{\circ} \mathrm{C}$ ), hidratação do solvente $(0$ a $24 \%$ de água), velocidade de agitação (100 a 250 rpm) e razão mássica solvente: sólido (2,5 a 4,5). Através da execução destes experimentos e análise estatística dos dados pode-se determinar além das condições ótimas para maximização do rendimento da extração, o comportamento dos compostos minoritários de interesse (ácidos graxos livres e compostos antioxidantes), o fenômeno de hidratação da fase extrato, os valores de densidade e viscosidade da fase extrato e o comportamento do índice de retenção. Além da análise estatística foi realizada, também, uma análise termodinâmica do processo de extração a qual possibilitou delimitar os valores das variáveis temperatura e hidratação do solvente que conferem espontaneidade ao processo de extração. Na faixa de trabalho de 40 a 60 ${ }^{\circ} \mathrm{C}$ pode-se observar que, independentemente da matéria-prima, a extração de sólidos solúveis é fortemente influenciada pelo teor de água no solvente alcoólico. $\mathrm{O}$ aumento do teor de água no etanol suprime fortemente a extração de sólidos solúveis enquanto o aumento da temperatura somente favorece o aumento do nível de extração para menores teores de água no solvente. Foi possível observar, ainda, que a hidratação da fase extrato praticamente independe da temperatura e que existe um equilíbrio entre a umidade do sólido e o nível de hidratação do solvente etanol. Em relação ao índice de retenção, foi possível observar que esta variável depende não somente das variáveis independentes estudadas, mas também da conformação do sólido. Os valores de índice de retenção para o pellet de farelo de arroz são de 30 a $58 \%$ menores que os obtidos para a soja em lâminas. A análise estatística possibilitou a seleção de condições de processo, temperatura e hidratação do etanol, que possibilitam a maximização da extração de sólidos solúveis e gama-orizanol e a minimização da retenção e da extração de acidez livre. A análise termodinâmica, realizada no intervalo de 50 a $100{ }^{\circ} \mathrm{C}$ indicou que as mudanças de entalpia e entropia no processo de extração de óleo diminuem à medida que o nível de hidratação do solvente aumenta. Em temperaturas acima de $80{ }^{\circ} \mathrm{C}$ foi possível a obtenção de valores negativos para a variação de energia livre para todos os tipos de solventes estudados. Estes resultados permitem inferir que o processo de extração usando etanol como solvente é possível, espontâneo e favorecido pelo aumento da temperatura. Em relação ao índice de retenção, os modelos estatísticos obtidos para esta resposta e, também, para a densidade e viscosidade da fase extrato propiciaram o cálculo do índice de retenção modificado através do qual foi possível observar que o hold-up de líquido aumenta com o aumento do valor da viscosidade do extrato. $\mathrm{Na}$ segunda fase do trabalho foi realizada a determinação teórica do número de estágios necessários para extração do óleo de farelo de arroz da matriz sólida utilizando o etanol como solvente. Foi observado que o número de estágios teóricos para as extrações com etanol é sempre superior em relação ao número necessário quando se utiliza hexano como solvente. Além disso, o número de contatos sucessivos aumenta à medida que a hidratação do solvente etanólico aumenta. Por outro lado, o aumento da temperatura do processo de extração possibilita a obtenção de valores similares de recuperação de óleo (fixada em 97\% neste trabalho) utilizando-se um número menor de estágios teóricos no extrator sólido-líquido (ESL). Foi realizado, também, estudo do equilíbrio líquidolíquido (ELL) de sistemas contendo óleos vegetais e solvente alcoólico na faixa de temperatura de 10 a $60^{\circ} \mathrm{C}$. Os resultados obtidos nesta etapa do estudo mostram que a solubilidade mútua dos compostos do sistema diminui com o aumento do teor de água no solvente e, por outro lado, aumenta com o aumento da temperatura do sistema. O conjunto de dados experimentais de ELL foi utilizado para ajustar os parâmetros do modelo UNIQUAC, sendo obtido desvio médio de 0,35\% entre os valores experimentais e calculados. Os parâmetros de interação estimados neste trabalho são úteis para prever a composição das fases líquidas formadas a partir do resfriamento da corrente de extrato oriunda do ESL. Foi observado que é possível recuperar o solvente com eficiência acima de $98 \%$ quando a corrente de extrato é resfriada de 80 a $25{ }^{\circ} \mathrm{C}$. O estudo do ELL é também necessário para o correto dimensionamento de extratores líquido-líquido dedicados à etapa de desacidificação do óleo vegetal. De maneira geral, pode-se inferir que o processo de extração de óleos vegetais de matrizes sólidas, com subsequente etapa de desacidificação por extração líquido-líquido, é tecnicamente viável com o uso de solvente biorenovável.

Palavras-chave: Extração sólido-líquido, Extração líquido-líquido, Etanol, Óleo de farelo de arroz, Óleo de soja, UNIQUAC. 
RODRIGUES, C. E. C. Use of biorenewable solvent in the extraction and deacidification of vegetable oils. 2011. 171 f. Thesis (Associate professorship) - Faculdade de Zootecnia e Engenharia de Alimentos, Universidade de São Paulo, Pirassuninga, 2011.

\begin{abstract}
The objective of this associate professorship thesis was to study technical feasibility of using alcoholic solvents as substitutes to hexane in the extraction of vegetable oils from solid matrices. From the environmental standpoint, the use of ethanol presents some very attractive advantages, once it may be produced by biotechnology, does not generate toxic residues, has a lower degree of flammability, and it is considered safe to human health. The economic advantages are also evident, once ethanol is produced in large scale in Brazil, and may always be recovered to the reused in the process. In this research, two oil product raw materials were analyzed: flaked soybeans and rice bran pellets. In the first phase of the research, a comprehensive study on solid-liquid equilibrium was carried out using four types of experimental designs in which the independent variables were temperature (ranging from 40 to $90{ }^{\circ} \mathrm{C}$ ), degree of hydration of the solvent ( 0 to $24 \%$ water), stirring speed (100 to $250 \mathrm{rpm}$ ), and solvent:solid mass ratio (2.5 to 4.5). By means of these trials and statistical analysis of the data, optimal conditions were determined to optimize extraction yield, as well as the behavior of minor compounds of interest (free fatty acids and antioxidant compounds), the phenomenon of extract phase hydration, density and viscosity of the extract phase, and behavior of the retention index. Besides statistical analysis, thermodynamics analysis of the extraction process was also carried out, enabling the determination of the values temperature and degree of solvent hydration, which confer spontaneity to the extraction process. It could be observed that, in the 40 to $60{ }^{\circ} \mathrm{C}$ range, no matter the raw material, extraction of soluble solids was strongly influenced by the level of water in the alcoholic solvent. Increased water concentration in ethanol strongly suppresses the extraction of soluble solids, whereas higher temperatures only favor increased extraction for lower levels of water in the solvent. Besides, it was possible to observe that hydration of the extract phase was practically independent of the temperature, and that there was a balance between the level of moisture of the solid and the degree of hydration of ethanol used as solvent. As for the retention index, it was possible to observe that this variable depended not only on the independent variables analyzed, but also on the form of the solid. Values of the retention index for rice bran pellets were 30 to $58 \%$ lower than those obtained for flaked soybeans. Statistical analysis enabled the selection of process conditions, ethanol temperature and degree of hydration, which made possible to maximize the extraction of soluble solids and gamma-oryzanol, and to minimize retention index and extraction of free acidity. Thermodynamic analysis, carried out between 50 and $100{ }^{\circ} \mathrm{C}$, indicated that changes in enthalpy and entropy in the oil extraction process decreased as the degree of hydration of the solvent increased. At temperatures above $80{ }^{\circ} \mathrm{C}$, it was possible to find negative values for the variation in free energy for all types of solvents studied. These results made it possible to infer that the extraction process using ethanol as the solvent is feasible, spontaneous and favored by the increase in temperature. As for the retention index, statistical models obtained for this response, as well as the density and viscosity of the extract phase enabled the calculation of the modified retention index, which showed that hold-up of the liquid increased together with the viscosity of the extract. In the second phase of the study, the number of stages necessary for the extraction of rice bran oil from the solid matrix using ethanol was theoretically determined. It was observed that the number of theoretical stages for the extraction with ethanol is always higher than the number necessary when hexane is used as the solvent. Besides, the number of successive contacts increased with the degree of hydration of ethanol. On the other hand, the increase in temperature in the extraction process yielded similar values for oil recovery (fixed in $97 \%$ in this study), using a lesser number of theoretical stages in the solid-liquid extractor (SLE). A liquid-liquid equilibrium (LLE) study of systems containing vegetable oils and alcoholic solvent was also carried out in the range of 10 to $60{ }^{\circ} \mathrm{C}$. Results obtained in this stage of the study showed that mutual solubility of the compounds in the system decreased with the higher level of hydration of the solvent and, on the other hand, increased with the temperature of the system. The set of LLE experimental data was used to adjust the parameters of the UNIQUAC model, which showed mean deviation of $0.35 \%$ between experimental and calculated values. Interaction parameters estimated in this study are useful to predict a composition of the liquid phases formed after the extract flow from SLE was cooled. It was possible to recover the solvent with an efficiency rate over $98 \%$ when the extract flow was cooled from 80 to $25^{\circ} \mathrm{C}$. The study of LLE is also necessary to determine the correct size of liquid-liquid extractors used in deacidification of vegetable oils. It could be inferred that, in general, the process of vegetable oil extraction from solid matrices, with subsequent deacification by liquid-liquid extraction, is technically feasible with the use of a biorenewable solvent.
\end{abstract}

Key-words: Solid-liquid extraction, Liquid-liquid extraction, Ethanol, Rice bran oil, Soybean oil, UNIQUAC model. 


\section{Lista de Figuras}

\section{CAPÍTULO 1}

Figura 1.1. Componentes de um grão de arroz (UFRGS, 2011).

Figura 1.2 - Estados produtores de milho e soja no Brasil (Olicer Cereales, 2011).

Figura 1.3 - Distribuição geográfica das usinas de processamento de cana-de-açúcar no Brasil (UNICA, 2011).

Figura 1.4 - Processamento integrado de oleaginosas (adaptado de Anderson, 2005).

Figura 1.5 - Processo de extração de óleos vegetais e recuperação do farelo desengordurado (adaptado de Anderson, 2005).

Figura 1.6 - Etapas de purificação na produção de óleos vegetais comestíveis. 42

\section{CAPÍTULO 2}

Figura 2.1 - Célula de equilíbrio em vidro pyrex utilizada para determinação dos dados de equilíbrio. A: Termômetro de resistência; B: Sonda; C: Vedação; D: Retirada de amostras; E: Septos; F: Entrada de fluido termostático; G: Saída de fluido termostático.

Figura 2.2 - Procedimento para obtenção de dados de equilíbrio sólido-líquido para sistemas de extração de óleo de soja e de farelo de arroz.

Figura 2.3 - Esquema do extrator de aço inox utilizado para determinação dos dados de equilíbrio. a) vista lateral; b) vista superior.

Figura 2.4 - Extrator de aço inox existente no Laboratório de Engenharia de Separações. a) foto de vista lateral; $b$ ) detalhe da tampa; c) detalhe do cesto. 53

Figura 2.5 - Representação esquemática do ESL com n estágios operando em contracorrente. 64

\section{CAPÍTULO 3}

Figura 3.1 - Curvas de contorno para Transferência de sólidos solúveis $\left(T_{\text {Sol }}\right)$ como função da temperatura $\left({ }^{\circ} \mathrm{C}\right)$ e teor de água no solvente (\% em massa) nos sistemas: a) farelo de arroz; b) soja.

Figura 3.2 - Curvas de contorno para Transferência de ácidos graxos livres $\left(T_{A G L}\right)$ como função da temperatura $\left({ }^{\circ} \mathrm{C}\right)$ e teor de água no solvente (\% em massa) nos sistemas: a) farelo de arroz; $b$ ) soja.

Figura 3.3 - Curvas de contorno para Transferência de gama-orizanol $\left(T_{\text {Oriza }}\right)$ como função da temperatura $\left({ }^{\circ} \mathrm{C}\right)$ e teor de água no solvente (\% em massa).

Figura 3.4 - Curvas de contorno para Transferência de água $\left(T_{\text {Água }}\right)$ como função da temperatura $\left({ }^{\circ} \mathrm{C}\right)$ e teor de água no solvente (\% em massa) no sistema com farelo de arroz.

Figura 3.5 - Curvas de contorno para conteúdo de água na fase extrato (Água ${ }_{F E}$ ) como função da temperatura $\left({ }^{\circ} \mathrm{C}\right)$ e teor de água no solvente (\% em massa) nos sistemas: a) farelo de arroz; b) soja.

Figura 3.6 - Curvas de contorno para índice de retenção (RI) como função da temperatura $\left({ }^{\circ} \mathrm{C}\right)$ e teor de água no solvente (\% em massa) nos sistemas: a) farelo de arroz; b) soja. 85

Figura 3.7 - Curvas de contorno para a função otimizada $(F O)$ como função da temperatura $\left({ }^{\circ} \mathrm{C}\right)$ e teor de água no solvente (\% em massa).

\section{CAPÍTULO 4}

Figura 4.1 - Variação da energia livre de Gibbs como função da temperatura. Conteúdo de água no solvente: (口) 0,06 $\pm 0,07 \%$ em massa; ( O) 1,85 $\pm 0,06 \%$ em massa; ( $\mathbf{\Delta}$ ) 5,97 $\pm 0,08 \%$ em massa; ( $\nabla) 10,39 \pm 0,01 \%$ em massa; ( •) 12,56 $\pm 0,81 \%$ em massa.

Figura 4.2 - Curvas de contorno para Rendimento de extração (Rend) como função da temperatura $\left({ }^{\circ} \mathrm{C}\right)$ e teor de água no solvente (\% em massa) para o sistema com soja laminada.

Figura 4.3 - Curvas de contorno para Transferência de sólidos solúveis $\left(T_{\text {Sol }}\right)$ como função da temperatura $\left({ }^{\circ} \mathrm{C}\right)$

e teor de água no solvente (\% em massa) para o sistema com soja laminada. 
Figura 4.4 - Curvas de contorno para Transferência de água $\left(T_{\text {Água }}\right)$ como função da temperatura $\left({ }^{\circ} \mathrm{C}\right)$ e teor de água no solvente (\% em massa) para o sistema com soja laminada.

Figura 4.5 - Curvas de contorno para conteúdo de água na fase extrato (Água ${ }_{F E}$ ) como função da temperatura

$\left({ }^{\circ} \mathrm{C}\right)$ e teor de água no solvente (\% em massa) para o sistema com soja laminada.

Figura 4.6 - Curvas de contorno para o Índice de Retenção (RI) como função da temperatura $\left({ }^{\circ} \mathrm{C}\right)$ e teor de água no solvente (\% em massa) para o sistema com soja laminada.

Figura 4.7 - Curvas de contorno para a Densidade da fase extrato $\left(\rho_{F E}\right)$ como função da temperatura $\left({ }^{\circ} \mathrm{C}\right) e$ teor de água no solvente (\% em massa) para o sistema com soja laminada.

Figura 4.8 - Curvas de contorno para a Viscosidade da fase extrato $\left(n_{F E}\right)$ como função da temperatura $\left({ }^{\circ} \mathrm{C}\right) e$ teor de água no solvente (\% em massa) para o sistema com soja laminada.

Figura 4.9 - Curvas de contorno para Transferência de sólidos solúveis $\left(T_{\text {Sol }}\right)$ como função da temperatura $\left({ }^{\circ} \mathrm{C}\right)$ e teor de água no solvente (\% em massa) para o sistema com farelo de arroz.

Figura 4.10 - Curvas de contorno para conteúdo de água na fase extrato (Água ${ }_{F E}$ ) como função da temperatura $\left({ }^{\circ} \mathrm{C}\right)$ e teor de água no solvente $(\%$ em massa) para o sistema com farelo de arroz.

Figura 4.11 - Curvas de contorno para o Índice de Retenção $(R I)$ como função da temperatura $\left({ }^{\circ} \mathrm{C}\right)$ e teor de água no solvente (\% em massa) para o sistema com farelo de arroz.

Figura 4.12 - Curvas de contorno para retenção (RI) nos sistemas com farelo de arroz: a) como função da razão mássica solvente: farelo $(\mathrm{m} / \mathrm{m})$ e teor de água no solvente (\% em massa); $b$ ) como função da velocidade de agitação (rpm) e teor de água no solvente (\% em massa).

Figura 4.13 - Curvas de contorno para a Densidade da fase extrato $\left(\rho_{F E}\right)$ como função da temperatura $\left({ }^{\circ} \mathrm{C}\right) e$ teor de água no solvente (\% em massa) para o sistema com farelo de arroz.

Figura 4.14 - Curvas de contorno para a Viscosidade da fase extrato $\left(n_{F E}\right)$ como função da temperatura $\left({ }^{\circ} \mathrm{C}\right) e$ teor de água no solvente (\% em massa) para o sistema com farelo de arroz.

Figura 4.15 - Viscosidades $(\eta)$ e densidades $(\rho)$ como função da temperatura $\left({ }^{\circ} \mathrm{C}\right)$ para os compostos puros:

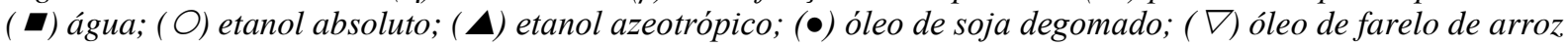
degomado.

Figura 4.16 - Índice de retenção modificado (RI*) como função da viscosidade da fase extrato ( $\left.\eta_{F E}\right)$, para diferentes conteúdos de água no solvente (\% em massa): a) Sistema com soja, ( $\boldsymbol{\square}) 0 \%$; ( O) 1,9\%; ( $\mathbf{\Delta}) 6 \%$;

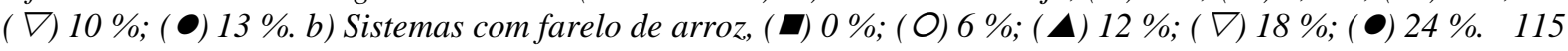

\section{CAPÍTULO 5}

Figura 5.1 - Curvas de contorno para Rendimento de extração (Rend) como função: $\left(\right.$ a) da temperatura $\left({ }^{\circ} \mathrm{C}\right) e$ teor de água no solvente (\% em massa), com $X_{3}=3,5$ e $X_{4}=175 \mathrm{rpm} ;(\mathrm{b})$ da temperatura $\left({ }^{\circ} \mathrm{C}\right)$ e razão solvente: sólido, com $X_{1}=6 \%$ em massa e $X_{4}=175 \mathrm{rpm}$.

Figura 5.2 - Curvas de contorno para Concentração de nutracêutico ( $\mathrm{mg} / \mathrm{kg}$ farelo de arroz) como função da temperatura $\left({ }^{\circ} \mathrm{C}\right)$ e teor de água no solvente (\% em massa), com $X_{3}=3,5$ e $X_{4}=175 \mathrm{rpm}$ : a) Orizanol; b) Tocóis.

Figura 5.3 - Estruturas químicas de três componentes do gama-orizanol.

\section{CAPÍTULO 6}

Figura 6.1 - Sistemas compostos por óleo de farelo de arroz degomado (1) + ácidos graxos livres (2) + solvente [etanol (3) + água (4)]: ( ( ) experimental; (- - ) calculado pelo modelo UNIQUAC. a) 6,34 \pm 0,03\% de água em massa, a 10,0 $\pm 0,1{ }^{\circ} \mathrm{C}$; b) 6,34 $\pm 0,03 \%$ de água em massa, a 35,0 $\pm 0,1{ }^{\circ} \mathrm{C} ; \mathrm{c}$ ) $18,87 \pm 0,07 \%$ de água em massa, a $35,0 \pm 0,1^{\circ} \mathrm{C}$.

Figura 6.2 - Coeficientes de distribuição dos ácidos graxos livres $\left(k_{2}\right)$ como função da temperatura, para diferentes razões óleo: solvente: a) $2: 1$; b) 1:1; c) 1:2. Exp: (O) $100 w_{4 S}=0,62 \pm 0,07 \%$; (ロ) $100 w_{4 S}=6,34 \pm$ $0,03 \%$; (4) $100 w_{4 S}=18,87 \pm 0,07 \%$; ( $) 100 w_{4 S}=28,29 \pm 0,05 \%$; (- - -) calculado pelo modelo UNIQUAC.

Figura 6.3 - Coeficientes de distribuição do gama-orizanol $\left(k_{5}\right)$ como função da temperatura, para diferentes razões óleo: solvente: a) $2: 1$; b) 1:1; c) 1:2. Exp: (0) $100 w_{4 S}=0,62 \pm 0,07 \%$; (n) $100 w_{4 S}=6,34 \pm 0,03 \%$; (4) $100 w_{4 S}=18,87 \pm 0,07 \%$; ( $\left.\boldsymbol{\nabla}\right) 100 w_{4 S}=28,29 \pm 0,05 \%$. 
Figura 6.4 - Coeficientes de distribuição dos tocóis $\left(k_{6}\right)$ como função da temperatura, para diferentes razões óleo: solvente: a) $2: 1$; b) $1: 1$; c) $1: 2$. Exp: (O) $100 w_{4 S}=0,62 \pm 0,07 \%$; (a) $100 w_{4 S}=6,34 \pm 0,03 \%$; (4) 100 $w_{4 S}=18,87 \pm 0,07 \% ;(\boldsymbol{\nabla}) 100 w_{4 S}=28,29 \pm 0,05 \%$.

Figura 6.5 - Número de estágios teóricos na ESL como função da razão mássica entre alimentação (farelo de arroz) e solvente ( $F: S)$ e temperatura de processo: a) $\left.50{ }^{\circ} \mathrm{C} ; \mathrm{b}\right) 80^{\circ} \mathrm{C}$.

Figura 6.6 - Solubilidade do solvente na fase rica em óleo $\left(100 w_{3+4}^{O P}\right):(\bullet) 100 w_{4 S}=0 \% ;(\boldsymbol{\Delta}) 100 w_{4 S}=6 \%$;

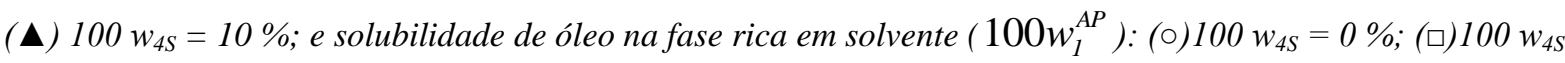
$=6 \% ;$ (4) $100 w_{4 S}=10 \%$, como função da temperatura de resfriamento para diferentes valores de F:S. (a) $e$ (d) $F: S=0,8$; (b) e (e) $F: S=1,0 ;(c) e(f) F: S=1,2$.

Figura 6.7 - Eficiência de recuperação do solvente (\%) como função da razão mássica alimentação: solvente ( F:S) e temperatura no processo de extração sólido-líquido: a) $50{ }^{\circ} \mathrm{C}$; b) $80^{\circ} \mathrm{C}$. 


\section{Lista de Tabelas}

\section{CAPÍTULO 1}

Tabela 1.1 - Conteúdo típico de óleo e proteínas em alguns materiais oleaginosos.

Tabela 1.2 - Solventes alternativos sugeridos para extração de óleos vegetais.

Tabela 1.3 - Estudos desenvolvidos com etanol como solvente alternativo para extração de óleos vegetais.

Tabela 1.4 - Métodos alternativos de desacidificação de óleos vegetais.

Tabela 1.5 - Solventes propostos para desacidificação de óleos vegetais por ELL.

\section{CAPÍTULO 2}

Tabela 2.1 - Variáveis codificadas para o primeiro planejamento. 55

Tabela 2.2 - Variáveis codificadas para o segundo planejamento. 56

Tabela 2.3 - Variáveis codificadas para o terceiro planejamento. 57

Tabela 2.4 - Balanços globais de massa para cada estágio do ESL.

\section{CAPÍTULO 3}

Tabela 3.1 - Caracterização das matérias-primas, farelo de arroz e soja laminada. 73

Tabela 3.2 - Composição em ácidos graxos dos óleos de farelo de arroz e de soja.

Tabela 3.3 - Planejamento experimental ( $2^{2}+4$ pontos axiais +3 pontos centrais) referente ao farelo de arroz. 75 Tabela 3.4 - Planejamento experimental $\left(2^{2}+4\right.$ pontos axiais +3 pontos centrais) referente à soja laminada. _ 76

Tabela 3.5 - Modelos estatísticos para a matéria-prima farelo de arroz. ___ 77

Tabela 3.6 - Modelos estatísticos para a matéria-prima soja laminada.______ 77

Tabela 3.7 - Análise de variância (ANOVA) para farelo de arroz (análise a $90 \%$ de confiança).___ 78

Tabela 3.8 - Análise de variância (ANOVA) para soja laminada (análise a $95 \%$ de confiança). ___ 78

\section{CAPÍTULO 4}

Tabela 4.1 - Efeitos da hidratação do solvente e temperatura de processo no coeficiente de distribuição do óleo de soja.

Tabela 4.2 - Parâmetros termodinâmicos do processo de extração. ____ 91

Tabela 4.3 - Planejamento experimental $\left(2^{2}+4\right.$ pontos axiais +4 pontos centrais) referente à soja laminada. _ 95

Tabela 4.4 - Modelos estatísticos para a matéria-prima soja laminada. 96

Tabela 4.5 - Análise de variância (ANOVA) para a matéria-prima soja laminada (análise a $95 \%$ de confiança).

Tabela 4.6 - Planejamento experimental $\left(2^{4}+8\right.$ pontos axiais +5 pontos centrais) referente ao farelo de arroz.

Tabela 4.7 - Modelos estatísticos para a matéria-prima farelo de arroz. 105

Tabela 4.8 - Análise de variância (ANOVA) para a matéria-prima farelo de arroz (análise a $95 \%$ de confiança). 106

\section{CAPÍTULO 5}

Tabela 5.1 - Caracterização do farelo de arroz. 119

Tabela 5.2 - Composição em ácidos graxos do óleo de farelo de arroz. 120 
Tabela 5.3 - Planejamento experimental $\left(2^{4}+8\right.$ pontos axiais +5 pontos centrais $)$ para a matéria-prima farelo de arroz.

Tabela 5.4 - Análise de Variância (ANOVA) para a matéria-prima farelo de arroz (análise a 95\% de confiança).

Tabela 5.5 - Modelos estatísticos para a matéria-prima farelo de arroz.

\section{CAPÍTULO 6}

Tabela 6.1 - Composição em ácidos graxos do óleo de farelo de arroz (OFA).

Tabela 6.2 - Provável composição em triacilgliceróis (TAG) do óleo de farelo de arroz degomado.

Tabela 6.3-Massas molares médias e parâmetros estruturais de área $\left(q_{i}{ }^{\prime}\right)$ e volume $\left(r_{i}{ }^{\prime}\right)$.

Tabela 6.4 - Dados de equilíbrio líquido-líquido para sistemas contendo óleo de farelo de arroz degomado (1)

+ ácidos graxos livres (2) + etanol (3) + água (4), em diferentes temperaturas.

Tabela 6.5 - Parâmetros para o modelo UNIQUAC.

Tabela 6.6-Desvios médios nas composições das fases. 148

Tabela 6.7 - Vazões mássicas e composições das correntes de saída do extrator sólido-líquido. 150 


\section{Sumário}

Introdução e Objetivos 16

\section{CAPÍTULO 1}

1.1. A importância nutricional dos óleos vegetais 21

1.1.1. Óleo de soja_____ 22

1.1.2. Óleo de farelo de arroz ____ 22

1.2. A importância das agroindústrias de óleos vegetais e etanol para a economia do país ___ 23

1.3. Processo de obtenção de óleos vegetais __ 26

1.3.1. Obtenção de óleos vegetais por extração com solvente ___ 28

1.3.2. A utilização potencial do etanol como extratante de óleos vegetais ____ 36

1.4. Processos de refino de óleos vegetais___ 41

1.4.1. Desacidificação de óleos vegetais por extração líquido-líquido utilizando etanol como solvente 45

\section{CAPÍTULO 2}

2.1. Material e Métodos__ 49

2.1.1. Material_____ 49

2.1.1.1. Reagentes____________ 49

2.1.1.2. Equipamentos ___ 49

2.1.2. Métodos__ 50

2.1.2.1. Caracterização das Matérias Primas _ـ 50

2.1.2.2. Determinação dos Dados de Equilíbrio Sólido-líquido___ 51

2.1.2.3. Planejamento Fatorial - Extração sólido-líquido____________________ 54

2.1.2.4. Determinação dos Dados de Equilíbrio líquido-líquido ___ 57

2.1.2.5. Análises da Fase Extrato (ESL), Fases Alcoólica e Oleosa (ELL) e matérias-primas _ 58

2.1.2.5.1. Determinação de Umidade na Soja e Farelo de arroz ___ 58

2.1.2.5.2. Determinação da Concentração de Ácidos Graxos Livres____ 58

2.1.2.5.3. Determinação da Concentração de Solvente (Etanol + Água)___ 59

2.1.2.5.4. Determinação da Concentração de Água ___ 59

2.1.2.5.5. Determinação da Composição em Ácidos Graxos Livres (Fatty acid methyl esters -

FAME) _ 59

2.1.2.5.6. Cálculo do Índice de Iodo via cromatografia gasosa ___ 60

2.1.2.5.7. Determinação da Concentração de gama-orizanol ______ 60

2.1.2.5.8. Determinação da Concentração de Vitamina E (tocóis = tocoferóis + tocotrienóis) 61

2.1.2.5.9. Determinação do conteúdo de proteína nas matérias-primas___ 61

2.1.2.5.10. Determinação da Concentração de Óleo ____________ 61

2.1.2.5.11. Determinação das propriedades físicas dos compostos puros e extratos alcoólicos:

Densidade e Viscosidade ___ 62

2.1.2.6 Cálculos de Balanço de Massa para Estimativa da Composição da Fase Rafinado e Massa

da Fase Extrato ___ 62

2.1.2.7 Cálculos dos Parâmetros Termodinâmicos do Processo de Extração_______ 63 
2.1.2.8. Simulação do processo de extração sólido-líquido 64

2.1.2.9. Procedimento de avaliação da qualidade dos dados experimentais de equilíbrio líquidolíquido 66

2.1.2.10. Procedimento de modelagem dos dados experimentais de equilíbrio líquido-líquido 67

2.1.2.11. Estudo do processo de resfriamento dos extratos etanólicos 70

\section{CAPÍTULO 3}

3.1. Considerações Iniciais 72

3.2. Resultados e Discussão 72

3.2.1. Caracterização das matérias-primas, farelo de arroz em pellets e soja laminada 72

3.2.2. Análise estatística do processo de extração 74

3.2.3. Otimização do processo de extração de óleo de farelo de arroz 86

3.3. Conclusões 87

\section{CAPÍTULO 4}

4.1. Considerações Iniciais 90

4.2. Resultados e Discussão 90

4.2.1. Análise termodinâmica do processo de extração com solvente 90

4.2.2. Análise estatística do processo de extração para a matéria-prima soja laminada 94

4.2.3. Análise estatística do processo de extração para a matéria-prima farelo de arroz 102

4.2.4. Índice de retenção e propriedades físicas 114 4.3. Conclusões 117

\section{CAPÍTULO 5}

5.1. Considerações Iniciais 119

5.2. Resultados e Discussão 119

5.3. Conclusões 135

\section{CAPÍTULO 6}

6.1. Considerações Iniciais

6.2. Resultados e Discussão

6.2.1. Dados experimentais e modelagem termodinâmica do equilíbrio líquido-líquido 137

6.2.2. Simulação do Extrator Sólido-líquido 148

6.3. Conclusões 153

\section{CAPÍTULO 7}

Conclusões Gerais 155

\section{CAPÍTULO 8}

Direcionamento da linha de pesquisa 


\section{Introdução e Objetivos}

Os óleos vegetais comestíveis constituem uma importante fonte de energia, ácidos graxos essenciais, vitaminas e antioxidantes lipossolúveis. Os processos de obtenção de óleos vegetais comestíveis, os quais compreendem, em linhas gerais, a etapa de extração e subsequentes etapas de purificação, ou refino, apresentam impacto decisivo na qualidade (odor, sabor, cor), na funcionalidade (composição em ácidos graxos, vitaminas e antioxidantes) e no custo (rendimento, equipamentos e custo energético) do produto final.

O tipo de processo de extração ao qual será submetida a matriz oleaginosa depende do teor inicial de óleo contido no material. Para as matérias-primas de interesse nesta pesquisa, farelo de arroz e soja, a utilização de extração com solvente é o caminho mais viável devido ao baixo teor de óleo disponível (cerca de 20\%) (Anderson, 2005).

O solvente mais largamente empregado na extração de óleos de matrizes oleaginosas é um destilado de petróleo contendo uma mistura de isômeros de hexano (faixa de ebulição de 65 a $71{ }^{\circ} \mathrm{C}$ ) conhecido industrialmente como hexana. A hexana pode apresentar de 45 a $70 \%$ de n-hexano, composto que é considerado como neurotoxina nos Estados Unidos da América devido sua toxicidade comprovada em altas concentrações (Hammond et al., 2005).

Inúmeros tipos de solventes têm sido propostos para substituir a hexana na extração de óleos vegetais. De fato, existe hoje um considerável interesse na substituição deste solvente por outros solventes alternativos devido a uma crescente preocupação ambiental bem como com a segurança do processo (Hammond et al., 2005; Johnson e Lusas, 1983).

A utilização de solventes alcoólicos em substituição ao hexano apresenta vantagens bastante atrativas do ponto de vista ambiental, uma vez que o solvente sugerido é produzido por via biotecnológica, não gera resíduos tóxicos, apresenta menor risco de manuseio por seu menor grau de inflamabilidade e é considerado seguro para a saúde humana. Vantagens do ponto de vista econômico também são evidentes, uma vez que o etanol é produzido em larga escala no Brasil e pode ser facilmente recuperado, para posterior reutilização no processo.

Embora algumas vantagens da substituição do hexano pelo etanol sejam evidentes existem lacunas que devem ser respondidas através de um estudo sistematizado do processo de extração sólido-líquido. 
Esta tese de livre docência teve como objetivo principal o estudo da viabilidade técnica do emprego de solventes alcoólicos, etanol absoluto ou hidratado, no processo de extração de óleos vegetais, óleos de farelo de arroz e de soja.

Para se atingir os objetivos propostos, um amplo estudo do equilíbrio de fases de sistemas compostos por farelo de arroz em pellets ou soja em lâminas e solvente alcoólico foi realizado. Os dados de equilíbrio sólido-líquido foram analisados por metodologia de superfície de resposta, permitindo o conhecimento da influência das variáveis independentes selecionadas, grau de hidratação do solvente etanólico, temperatura do processo de extração, razão mássica sólido: solvente e velocidade de agitação sobre as respostas rendimento de extração, qualidade do óleo obtido e recuperação do solvente, entre outras.

De maneira geral, o processo de extração utilizando solvente biorenovável foi investigado sob a ótica de sua capacidade em maximizar a extração de triacilgliceróis e antioxidantes naturais, gama-orizanol, tocoferóis e tocotrienóis.

Em relação à recuperação do solvente, foi verificada a viabilidade de se realizar uma pré-recuperação do solvente através de resfriamento da corrente de extrato proveniente do extrator sólido-líquido. De fato, foi verificada, também, a possibilidade de se empregar a técnica de desacidificação por extração líquido-líquido, utilizando etanol como solvente, aliada ao processo de extração do óleo da matriz oleaginosa, empregando-se o mesmo solvente alternativo. Neste tópico, dados de equilíbrio líquidolíquido para sistemas compostos por óleo vegetal + etanol, com diferentes graus de hidratação, sob diferentes condições de temperatura, foram experimentalmente determinados e correlacionados por modelo semi-empírico descritivo (UNIQUAC). Os parâmetros de interação binária obtidos são úteis para a predição do equilíbrio de fases no processo de recuperação do solvente por resfriamento da fase extrato (mistura óleo+etanol) bem como para o projeto de extratores dedicados a desacidificação de óleos.

Os assuntos abordados em cada capítulo que compõe esta tese de livre docência estão resumidos a seguir:

Capítulo 1: Este capítulo apresenta uma breve revisão da literatura acerca dos processos de obtenção de óleos vegetais por extração com solvente e dos tipos de refino aos quais os óleos podem ser submetidos para tornarem-se comestíveis. 
Capítulo 2: O capítulo 2 apresenta os Materiais e Métodos utilizados para execução do trabalho.

Capítulo 3: Neste capítulo é apresentado estudo sobre a avaliação do desempenho do etanol, com ou sem hidratação, na extração de óleos de soja e de farelo de arroz das matrizes sólidas, considerando, inicialmente, a utilização de temperaturas amenas de processo, 40 a $60{ }^{\circ} \mathrm{C}$. São apresentados resultados pertinentes a dois planejamentos fatoriais completos nos quais as variáveis teor de água no solvente etanol (0 a $20 \%$, em massa) e temperatura $\left(40\right.$ a $60{ }^{\circ} \mathrm{C}$ ) foram consideradas como variáveis independentes.

Capítulo 4: Neste capítulo da tese são apresentados resultados decorrentes da realização de dois planejamentos fatoriais completos para as matérias-primas soja laminada e farelo de arroz em pellets. Nesta fase do estudo, as temperaturas de trabalho variaram de 60 a $90{ }^{\circ} \mathrm{C}$. As respostas de interesse foram: transferências de compostos lipídicos e água, índice de retenção, além do monitoramento dos valores das propriedades físicas, densidade e viscosidade, das fases extrato geradas.

Além da análise estatística foi realizada, também, uma análise termodinâmica do processo de extração a qual possibilitou delimitar os valores das variáveis temperatura e hidratação do solvente que conferem espontaneidade ao processo de extração.

Capítulo 5: No capítulo 5 é apresentado estudo referente a influência das variáveis independentes, nível de hidratação do solvente, temperatura, razão mássica solvente: farelo e velocidade de agitação sobre a extração de compostos minoritários de interesse, gama-orizanol e tocoferóis/tocotrienóis e, também, sobre a composição, em ácidos graxos, dos óleos de farelo de arroz extraídos com etanol.

Capítulo 6: Este capítulo apresenta estudo do processo de extração de óleo de farelo de arroz, via simulação computacional, o qual permitiu a estimativa do número de estágios teóricos necessários para a extração do óleo da matriz sólida utilizando extrator contínuo operando em contracorrente. Neste capítulo são apresentados, também, dados de equilíbrio líquido-líquido para sistemas compostos por óleo de farelo de arroz degomado e solvente alcoólico. Os parâmetros de interação do modelo UNIQUAC foram ajustados aos dados experimentais tornando possível não só a simulação de 
extratores líquido-líquido dedicados à desacidificação de óleos vegetais, mas também a predição das composições das fases, rica em óleo e rica em solvente, geradas a partir do resfriamento da corrente de extrato proveniente de extratores sólido-líquido quando etanol é utilizado como solvente.

Capítulo 7: Neste capítulo foram sintetizadas as principais conclusões obtidas durante o desenvolvimento do trabalho de pesquisa.

Capítulo 8: Neste capítulo são sugeridos tópicos para serem estudados os quais denotam a continuidade dos trabalhos na linha de pesquisa "Extração alcoólica de óleos vegetais". 
CATítulo 1

\section{REVISÃo BIBLIOGRÁFICA}




\subsection{A importância nutricional dos óleos vegetais}

A alimentação da população brasileira é considerada deficiente em vitaminas e minerais tanto quantitativamente, para as classes menos favorecidas, quanto qualitativamente, mesmo para as classes mais abastadas, as quais privilegiam o sabor em detrimento do valor nutritivo. O Brasil é classificado como tendo problema de saúde pública significante, destacando a baixa incidência e ingestão insatisfatória de alimentos ricos em micronutrientes tais como ferro, ácido fólico, cálcio, vitamina $\mathrm{A}$, vitaminas do complexo $\mathrm{B}$ e vitamina $\mathrm{E}$ (IBGE, 2011a; Velásquez-Meléndez et al., 1997).

O consumo em quantidades satisfatórias destes micronutrientes é essencial para o metabolismo de carboidratos, proteínas e gorduras e, também, para a formação do sangue. Estes micronutrientes também estão relacionados com o desenvolvimento e a manutenção do bom funcionamento do organismo humano. Como o organismo humano não consegue produzir as vitaminas, é necessário ingeri-las através dos alimentos e suplementos vitamínicos (FAO, 2010; Liberato e Pinheiro-Sant'ana, 2006).

Os óleos vegetais comestíveis apresentam-se como uma das principais fontes de gordura dietária. Estes, além de suprirem energia para o corpo humano, auxiliam na absorção de vitaminas e antioxidantes lipossolúveis, sendo, também, a principal fonte de ácidos graxos mono e poliinsaturados essenciais ao bom funcionamento do organismo humano. Estudos revelam que uma dieta balanceada para um homem adulto saudável deve conter cerca de 17 gramas/dia de ácido linoléico, um ácido graxo presente em óleos de girassol, soja, farelo de arroz, e cerca de 10 miligramas/dia de vitamina E, entre outros antioxidantes (Institute of Medicine, 2005).

Além das funções de provisão de energia e fornecimento de vitaminas e antioxidantes lipossolúveis, os óleos vegetais constituem uma importante fonte de ácidos graxos, alguns considerados essenciais ao organismo. O balanço certo entre a quantidade de ácidos graxos saturados, monoinsaturados e poliinsaturados auxilia na proteção do organismo contra doenças crônicas tais como doenças cardiovasculares (FAO, 2010; Deckere e Korver, 1996). Além dos ácidos graxos essenciais, os óleos vegetais contêm componentes minoritários

insaponificáveis com características antioxidantes e vitamínicas. Óleos vegetais ricos nestes componentes minoritários são, dentre outros, os óleos de soja e de farelo de arroz. 


\subsection{1. Óleo de soja}

O óleo de soja é o segundo óleo vegetal mais consumido no mundo, sendo ultrapassado somente pelo óleo de palma. No ano de 2010 o consumo mundial de óleo de soja atingiu a marca de $29 \%$, sendo este alto consumo decorrente, principalmente, da alta qualidade do óleo e baixo custo de produção (Soystats, 2011).

O óleo de soja bruto apresenta baixa acidez livre, 0,3 a 0,7\%, se comparado aos outros tipos de óleos vegetais e pode conter altos índices $(1,9$ a 2,8\%) de fosfolipídios. Substancialmente todos os triacilgliceróis que compõem o óleo de soja contém 2 ácidos graxos insaturados sendo que o ácido linoléico pode representar $57 \%$ e o ácido linolênico $10 \%$ dos ácidos graxos totais. A matéria insaponificável do óleo de soja, cerca de $1,5 \%$ do óleo, é formada por cerca de $16 \%$ de esteróis (2000 a $4000 \mathrm{mg} / \mathrm{kg}$ ), 8,5\% de tocoferóis (600 a $3400 \mathrm{mg} / \mathrm{kg}$ ) e $26 \%$ de hidrocarbonetos (Firestone, 1999; Swern, 1964; Hammond et al., 2005).

\subsection{2. Óleo de farelo de arroz}

O óleo de farelo de arroz é um sub-produto do beneficiamento do grão de arroz o qual é constituído genericamente por $20 \%$ de casca, $70 \%$ de endosperma e $10 \%$ pelas camadas de farelo e gérmen (Figura 1.1), sendo que no farelo estão concentrados a maior parte dos lipídios (15 a 20\%) (Orthoefer, 1996; McCaskill e Zhang, 1999).

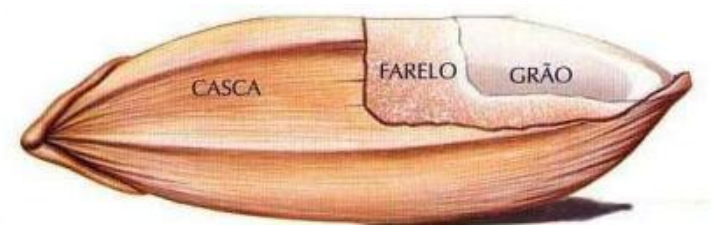

Figura 1.1. Componentes de um grão de arroz (UFRGS, 2011).

A composição típica do óleo de farelo de arroz bruto é de 68 a $71 \%$ de triacilgliceróis, 2 a 3\% de diacilgliceróis, 5 a 6\% de monoacilgliceróis, 2 a 3\% de ácidos graxos livres, 2 a 3\% de ceras, 5 a $7 \%$ de glicolipídios, 3 a 4\% de fosfolipídios e 4\% de matéria insaponificável (Orthoefer, 2005; McCaskill e Zhang, 1999).

Quanto à composição em ácidos graxos, tem-se que o ácido oléico e o linoléico constituem cerca de $80 \%$ dos ácidos graxos dos acilgliceróis (40\% de oléico e $40 \%$ de linoléico). Este óleo contém, também, quantidades detectáveis do ácido graxo $\alpha$-linolênico (1 a 3\%) e a maior quantidade de ácido graxo saturado no óleo de farelo de arroz é o ácido palmítico (17\%) (Farhoosh et al., 2011; Orthoefer, 2005; McCaskill e Zhang, 1999). 
O óleo de farelo de arroz bruto apresenta, em média, 4\% de matéria insaponificável, sendo $2 \%$ constituído por gama-orizanol, uma mistura complexa de ésteres de ácido ferúlico com fitosteróis e álcoois triterpênicos (Farhoosh et al., 2011; Lerma-García et al., 2009; Patel e Naik, 2004). Além do gama-orizanol, o óleo de farelo de arroz é um dos únicos óleos vegetais que contém níveis significativos de tocotrienóis, cerca de $1000 \mathrm{mg} / \mathrm{kg}$ (Sookwong et al., 2010). O gama-orizanol tem sido considerado um poderoso agente antioxidante e hipocolesterolêmico e os tocotrienóis, que apresentam, também, propriedade antioxidante, têm sido citados em pesquisas recentes como eficientes na prevenção de doenças cardiovasculares e algumas formas de câncer (Farhoosh et al., 2011; Lerma-García et al., 2009; McCaskill e Zhang, 1999).

\subsection{A importância das agroindústrias de óleos vegetais e etanol para a economia do país}

Segundo o Ministério do Desenvolvimento, Indústria e Comércio Exterior (Brasil, 2011a) o sistema agroindustrial brasileiro contribui com $28 \%$ do valor do Produto Interno Bruto (PIB), 36\% das exportações e 37\% dos empregos, além de ser considerado como uma liderança mundial em produtos commodities.

A indústria de óleos vegetais se destaca no setor agroindustrial pela expressividade do seu porte econômico. A variação no volume de produção de óleos vegetais, considerando o biênio 2010/2011, foi de 24,18\% (CEPEA, 2011a). Nesta indústria, a alta dos preços, paralelamente ao bom desempenho do volume processado, resulta em desempenho positivo. Segundo o CEPEA (2011b), a variação acumulada do PIB da agroindústria de óleos vegetais, no período de abril de 2010 a abril de 2011 , foi de 7,41\%.

A Figura 1.2 apresenta a distribuição geográfica das principais culturas de oleaginosas no Brasil, culturas de milho e soja. Nota-se, principalmente no caso da soja, a concentração da produção na região centro-sul, a qual se destaca por ser a região de economia mais dinâmica do país, produzindo a maior parte do PIB nos setores agrário, industrial e de serviços, além de concentrar a maior parte da população. 


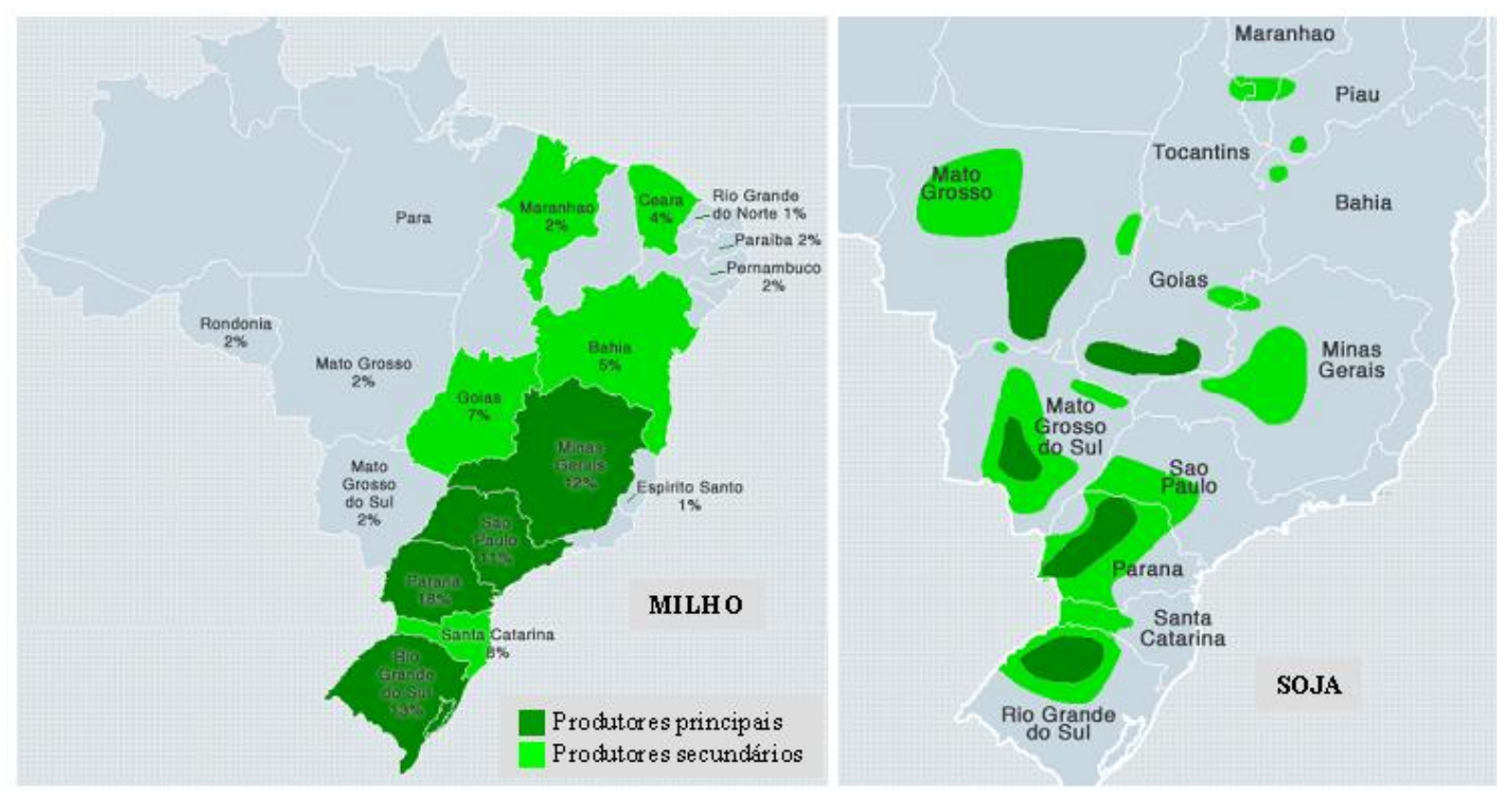

Figura 1.2 - Estados produtores de milho e soja no Brasil (Olicer Cereales, 2011).

A cultura da soja alcançou no ano de 2010 a marca de $58 \%$ de toda a produção mundial de grãos oleaginosos (Soystats, 2011), sendo o Brasil o segundo maior produtor mundial, contribuindo no ano supracitado com produção de cerca de 68,5 milhões de toneladas (IBGE, 2011b). Em relação à produção de óleo de soja, o Brasil é o quarto maior produtor e segundo maior exportador mundial, com projeção para o biênio 2011/2012 de 7 milhões de toneladas e 1,65 milhões de toneladas, respectivamente, para produção e exportação (USDA, 2011a).

No que se refere à cultura do arroz, a produção esperada no Brasil para o ano de 2011 segundo o IBGE (2011b) é 13,4 milhões de toneladas, em uma área plantada de 2,8 milhões de hectares. Notadamente o Estado do Rio Grande do Sul é o maior produtor nacional, contribuindo com cerca de 66\% da produção (IBGE, 2011b). O Brasil é o nono maior produtor de arroz do mundo, sendo que a produção no período 2010/2011, liderada pela China, atingiu a marca total de 451 milhões de toneladas (USDA, 2011b).

De acordo com Kahlon (2009), 63 a 76 milhões de toneladas de farelo de arroz são produzidas por ano no mundo, sendo que somente $10 \%$ deste montante são estabilizados e submetidos ao processo de extração de óleo de farelo de arroz (Kahlon, 2009). Desta forma, pode-se estimar que o potencial de produção de óleo de farelo de arroz no Brasil seria de cerca de 193 mil toneladas ao ano, considerando que o rendimento do farelo de arroz é de aproximadamente 8 a 10\% da produção do arroz em casca, e seu conteúdo de óleo é variável entre 14 e $18 \%$, dependendo das razões geográficas, de variedades de sementes e, também, de formas de processo de extração do óleo do farelo. 
Em relação à cana-de-açúcar, dados do Ministério da Agricultura, Pecuária e Abastecimento (Brasil, 2011b) mostram que esta é a terceira maior atividade agrícola do Brasil em termos de área de produção e de valor bruto produzido, somente perdendo para a soja e milho. Atualmente, a cana-de-açúcar ocupa cerca de 8,6 milhões de hectares em todo o país com produção de 682 milhões de toneladas (IBGE, 2011b). Na Figura 1.3 pode ser observada a distribuição geográfica das usinas de processamento de cana-de-açúcar.

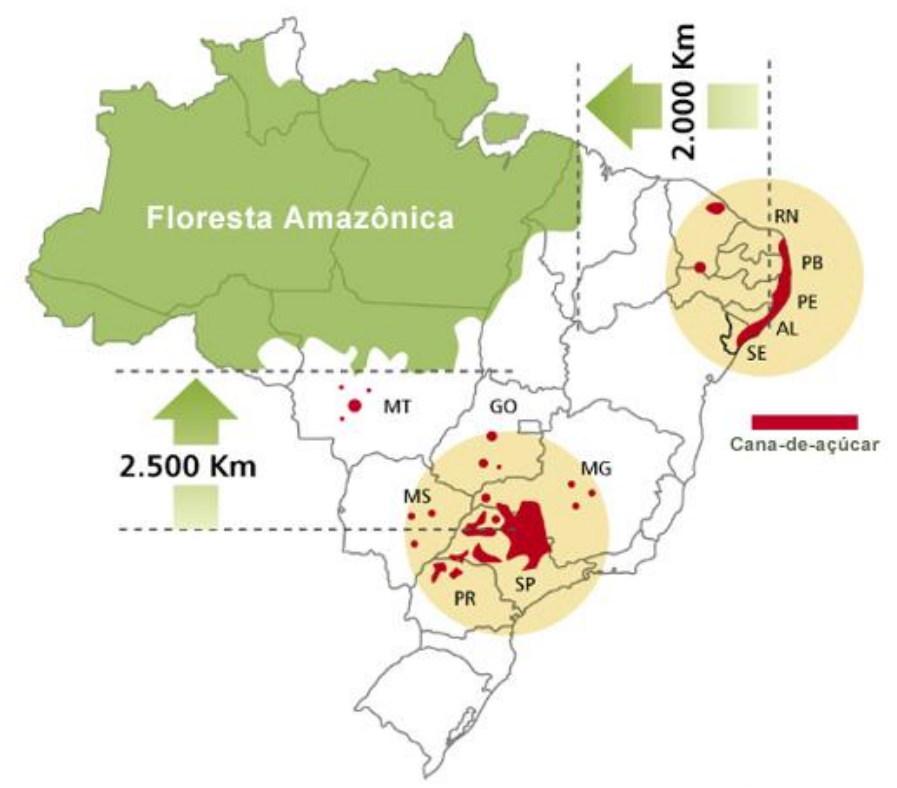

\section{Figura 1.3 - Distribuição geográfica das usinas de processamento de cana-de-açúcar no Brasil (UNICA, 2011).}

A região Centro-Sul do Brasil congrega as maiores unidades de processamento de cana-de-açúcar do país. Esta região foi responsável pela produção de cerca de 25,1 bilhões de litros de etanol na safra 2008/2009, enquanto a região Norte-Nordeste, na mesma safra, contribuiu com 2,4 bilhões de litros (UNICA, 2011). De acordo com o CEPEA (2011a), a indústria de produção de etanol registrou crescimento de 2,12\% no biênio 2010/2011.

Como pode ser observado nas Figuras 1.2 e 1.3, a região Centro-Sul detém a maioria esmagadora da produção de grãos oleaginosos e etanol do Brasil. Pode-se, desta forma, esperar um maior sinergismo entre estes dois grandes complexos agroindustriais viabilizandose tecnicamente o uso do álcool etílico no processo de extração dos óleos vegetais. Este procedimento pode ser bastante atrativo economicamente no Brasil. A adoção de tecnologia adequada pode possibilitar a substituição do hexano, a fração do petróleo utilizada atualmente para a extração dos óleos vegetais, pelo etanol, diminuindo a dependência do país em relação a este solvente fóssil. 


\subsection{Processo de obtenção de óleos vegetais}

No início da produção de óleos vegetais os estudos de otimização das diversas etapas do processo de extração e refino eram realizados de maneira isolada, com pequena ou nenhuma consideração acerca do impacto da modificação nas etapas subsequentes do processo ou na qualidade do produto final.

Nos últimos anos a ênfase mudou da otimização de etapas isoladas para a otimização da produção considerando todas as etapas integradas, produzindo com qualidade e lucratividade a maior quantidade possível de produtos com alto valor agregado. Desta forma, as sucessivas operações de purificação que compõem o refino de óleos vegetais tornaram-se mais dependentes umas das outras, sendo de extrema relevância a consideração do impacto das modificações nas etapas posteriores do processo (Anderson, 2005).

De maneira geral a produção de óleos vegetais pode ser representada por meio de um diagrama de blocos que representa o conjunto das inúmeras operações unitárias envolvidas (Figura 1.4).

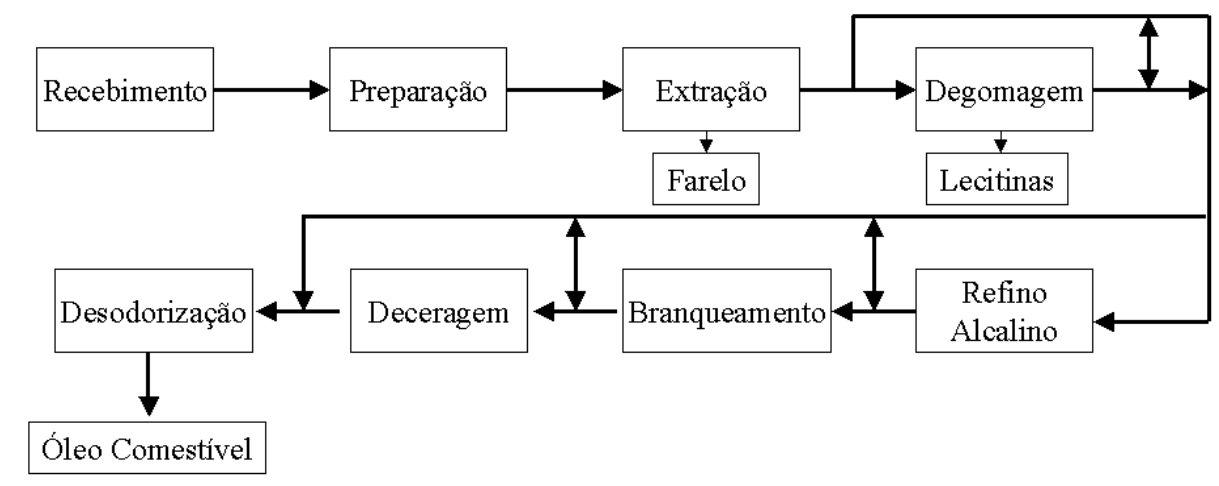

Figura 1.4 - Processamento integrado de oleaginosas (adaptado de Anderson, 2005).

A etapa de extração dos óleos vegetais a partir de sementes oleaginosas, polpa de frutos ou farelos apresenta-se como uma distinta e especializada seção dentro da área de tecnologia de óleos e gorduras (Kemper, 2005; Swern, 1964).

As diferenças nas características dos materiais oleaginosos determinam se a recuperação do óleo contido no material será realizada via prensagem mecânica ou por meio de emprego de solvente. Ambos os processos, entretanto, apresentam objetivos comuns. Primeiramente, obter um óleo ou gordura de boa qualidade e isento de impurezas; em segundo lugar, obter o óleo com alta produtividade zelando pela economia e lucratividade do processo; finalmente, produzir um resíduo de boa qualidade para consumo humano ou animal (Wakelyn e Wan, 2006). 
Os materiais vegetais, em particular, as sementes oleaginosas, apresentam grande quantidade de sólidos associada ao óleo, desta forma, uma eficiente separação deve prever uma cuidadosa redução do tamanho do material, a fim de aumentar a área de transferência de massa, seguida de um tratamento térmico e, por fim, a aplicação da pressão para separação da fase fluida.

Mesmo após uma eficiente prensagem a massa sólida pode conter uma quantidade apreciável de óleo residual, usualmente de 2,5 a 5\% em peso. No caso de sementes ou outros materiais com alto conteúdo inicial de óleo e baixo teor de sólidos, o resíduo pode conter apenas uma pequena fração do óleo total. Por outro lado, em sementes com baixo teor de óleo a torta pode conter de 15 a 20\% de óleo não extraído (Wakelyn e Wan, 2006).

Neste caso extremo, a extração do óleo com a utilização de solventes torna-se o caminho mais viável uma vez que este procedimento possibilita a redução do teor de óleo na semente para menos que 1\% (Ixtaina et al., 2011; Van Hoed et al., 2010; Kemper, 2005; Dunford e Zhang, 2003; Rosenthal et al., 1998).

O processo combinado que utiliza uma pré-prensagem seguida da extração por solvente é geralmente utilizado para sementes com alto teor de óleo (conteúdo de óleo acima de $35 \%$ ) tais como linhaça, girassol, algodão e gérmen de milho. Para a soja e farelo de arroz, matérias-primas de interesse nesta tese, emprega-se, geralmente, somente extração com solvente devido ao baixo conteúdo de óleo em relação a outros materiais oleaginosos, como mostrado na Tabela 1.1.

Tabela 1.1 - Conteúdo típico de óleo e proteínas em alguns materiais oleaginosos.

\begin{tabular}{|c|c|c|}
\hline Material & Óleo (\%) & Proteína (\%) \\
\hline Soja $^{a}$ & 21,4 & 40,7 \\
\hline Canola $^{\mathrm{b}}$ & $38-44$ & 20 \\
\hline Coco ${ }^{\mathrm{c}, \mathrm{d}}$ & 68 & 7,0 \\
\hline Gérmen de Milho $^{\mathrm{e}}$ & 30 & $23-25$ \\
\hline Linhaça $^{\mathrm{f}}$ & $35-45$ & 25 \\
\hline Farelo de Arroz ${ }^{\mathrm{g}}$ & $18-22$ & $12-16$ \\
\hline
\end{tabular}

De maneira geral, a extração por solvente apresenta algumas vantagens em relação à extração mecânica tais como maior rendimento, a produção de um resíduo isento de óleo e, devido ao mínimo pré-tratamento térmico da matriz sólida, a obtenção de um resíduo com menor nível de proteínas desnaturadas e um óleo de melhor qualidade (Wakelyn e Wan, 2006). Em relação a este último ponto, Van Hoed et al. (2010) observaram que o conteúdo de 
compostos minoritários em óleos brutos obtidos por extração com solvente é ligeiramente superior ao conteúdo observado em óleos obtidos por prensagem.

A seguir serão discutidas particularidades da extração de óleos vegetais por solvente.

\subsubsection{Obtenção de óleos vegetais por extração com solvente}

A extração por solvente pode ser definida como um processo de transporte de massa de uma fase para outra com o propósito de separar um ou mais componentes da mistura. No caso da extração de óleos vegetais, o óleo bruto é separado via solvente das proteínas e carboidratos que compõem a semente. Vários solventes têm sido usados comercialmente, mas, geralmente, o hexano é o solvente escolhido pelos processadores de óleos vegetais.

A extração de óleos vegetais por solvente envolve mecanismos de lixiviação, lavagem, difusão e diálise (Williams, 2005; Becker, 1978; Karnofsky, 1949).

O êxito da extração sólido-líquido depende, em grande parte, do tratamento prévio dado à matéria-prima oleaginosa. No caso de sementes oleaginosas, tal como a soja, na maioria das vezes estas são quebradas em 4 partes em moinhos, sendo as partículas finas e as cascas separados por aspiração. Os pedaços dos grãos são aquecidos em cozedores até $60{ }^{\circ} \mathrm{C}$ e laminados através de rolos que se movimentam com velocidade de 250 a $300 \mathrm{rpm}$. As partículas laminadas geradas apresentam de 0,3 a 0,4 $\mathrm{mm}$ de espessura e 8 a $18 \mathrm{~mm}$ de diâmetro (Kemper, 2005). Este último material, material oleaginoso laminado, já pode ser utilizado na extração, no entanto, é possível aumentar ainda mais a eficiência de transferência de massa transformando os flocos em pellets esponjosos com injeção de vapor. As lâminas oleaginosas são aquecidas a $90-110{ }^{\circ} \mathrm{C}$ e submetidas a uma diminuição de pressão abrupta o que causa uma súbita vaporização da umidade contida no material. Deste procedimento é gerado um produto tipo pellet, apresentando maior densidade e maior porosidade que o material laminado. Neste caso, os equipamentos industriais são comumente chamados de Expanders ${ }^{\circledR}$ e o material oleaginoso resultante é chamado de material expandido (Kemper, 2005).

De fato, o processo de extrusão, além de aumentar a área de contato entre sólido e solvente, também pode ser utilizado com o objetivo de desativar fatores antinutricionais presentes nos materiais oleaginosos. Em termos de processo, os materiais em pellets conferem maior facilidade de percolação e drenagem do solvente e, consequentemente, menor requerimento de energia na etapa de dessolventização do sólido (Riaz, 2005).

De maneira geral, as operações de preparo da matéria-prima distorcem as células causando a ruptura das paredes e dos esferossomas, que são os principais depósitos de 
lipídeos nas sementes e frutos oleaginosos (Rosenthal et. al., 1996). A maior parte do óleo é extraída no momento da ruptura das células sendo o mecanismo de transferência governado pelo fluxo capilar; a velocidade de transferência do óleo é particularmente dependente da viscosidade do solvente e da miscela (mistura óleo + solvente) nas condições de operação. Uma pequena quantidade de óleo residual deve ser transferida por osmose e a velocidade desta etapa depende dos tamanhos das moléculas de óleo e solvente.

A Figura 1.5 apresenta de forma simplificada a etapa de extração de óleos vegetais por solvente.

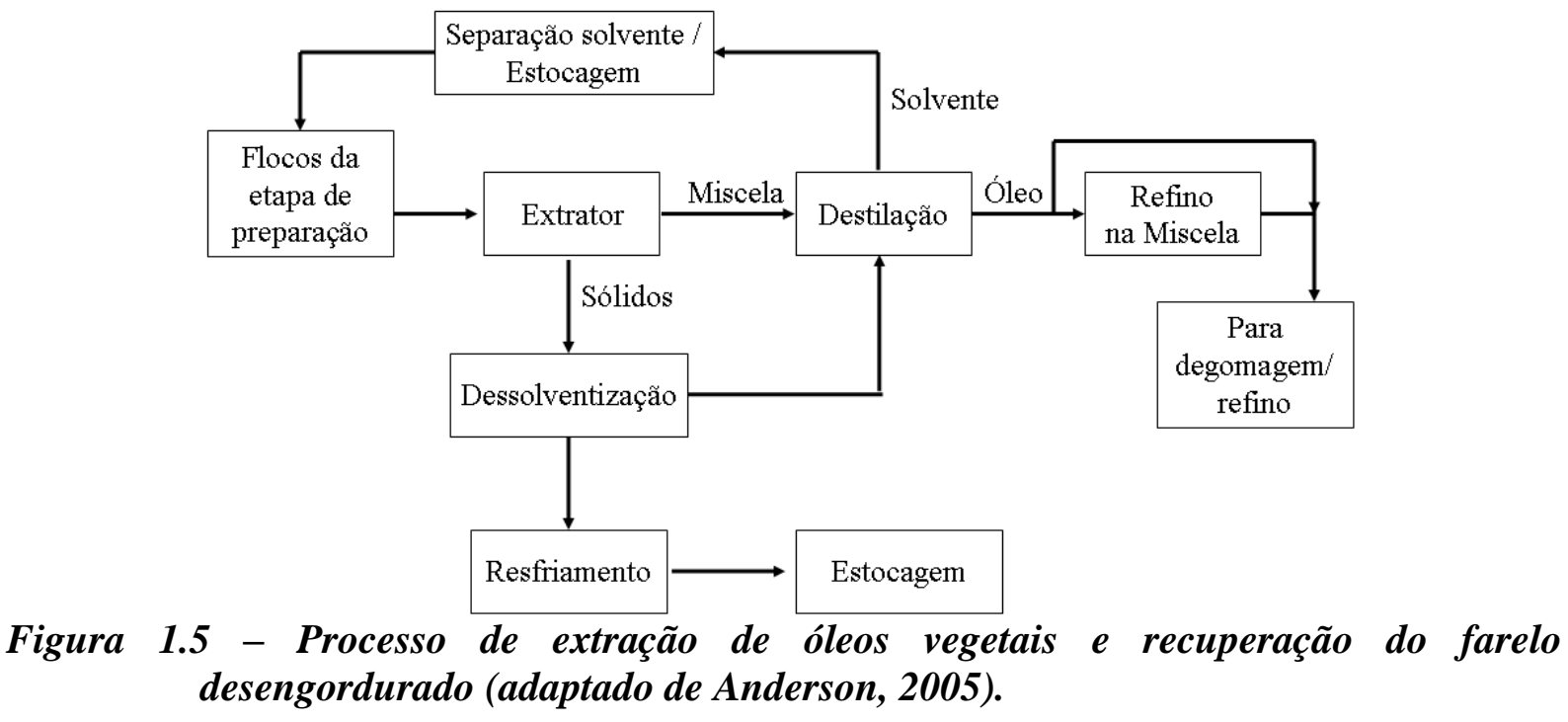

Em linhas gerais, algumas propriedades desejáveis em solventes para extração de óleos vegetais são (Johnson e Lusas, 1983):

- Alta solubilidade a elevada temperatura e baixa solubilidade a temperatura ambiente, possibilitando a separação das fases oleosa e solvente sem a necessidade de evaporação/destilação. Os alcoóis de cadeia curta exibem esta característica;

- Alta seletividade a triacilgliceróis, deixando no farelo desengordurado fosfolipídios, ceras e ácidos graxos livres, facilitando o refino posterior;

- Em alguns casos é desejável que o solvente extraia outros componentes junto com os triacilgliceróis tais como aflatoxinas, no caso do amendoim, e gossipol, no caso do algodão, viabilizando o emprego do farelo desengordurado como ração animal;

- Baixa inflamabilidade a fim de prevenir acidentes;

- Estabilidade a fim de prevenir a contaminação do óleo e do farelo;

- Inertes no contato com equipamentos a fim de minimizar gastos com manutenção;

- Alta pureza para uniformizar as características operacionais;

- Grande oferta a baixos preços. 
O solvente mais largamente empregado na extração de óleos de matrizes oleaginosas é um destilado de petróleo contendo uma mistura de isômeros de hexano (faixa de ebulição de 65 a $71{ }^{\circ} \mathrm{C}$ ) conhecido industrialmente como hexana. A hexana pode apresentar de 45 a $70 \%$ de n-hexano, além de metil-ciclopentano, 3-metil-pentano, 2-metil-pentano e ciclohexano (Wakelyn e Wan, 2006; Hammond et al., 2005).

Embora a hexana não apresente todas as propriedades supramencionadas esta se tornou o mais utilizado solvente para extração de óleos devido, principalmente, à alta estabilidade, baixa corrosão, baixo conteúdo de óleo residual e melhor odor do farelo desengordurado (Williams, 2005; Johnson e Lusas, 1983; Christensen, 1983).

A utilização da hexana como solvente para óleos vegetais apresenta evidentes desvantagens em termos de segurança ambiental, segurança do processo e para a saúde humana. O componente principal da hexana, o n-hexano, é uma neurotoxina que causa danos ao sistema nervoso central em ratos e humanos, em situação de exposição contínua por vários meses, a $500 \mathrm{mg} / \mathrm{kg}$ e $125 \mathrm{mg} / \mathrm{kg}$, respectivamente (Oh et al., 2005; Hammond et al., 2005; American Petroleum Institute, 1983). Além disso, o n-hexano é considerado perigoso à poluição do ar (hazardous air pollutant, HAP) pela Agência de Proteção Ambiental dos Estados Unidos da América (EPA) (Wakelyn e Wan, 2006).

De fato, durante o processo produtivo vapores de hexano podem ser perdidos para o ambiente, provocando subsequentes explosões em tanques de estocagem, nos extratores e nos equipamentos de recuperação do solvente (dessolventização do óleo e do farelo) (Landucci et al., 2011; Wakelyn e Wan, 2006).

Em relação à ingestão, o órgão americano Food and Drug Administration (FDA, 2011) regulamenta um resíduo menor que $25 \mathrm{mg} / \mathrm{kg}$ de $\mathrm{n}$-hexano nos óleos vegetais comestíveis, enquanto que na Europa o limite residual máximo aceitável é de $1 \mathrm{mg} / \mathrm{kg}$ (European Union, 2009).

Inúmeros tipos de solventes têm sido propostos para substituir a hexana na extração de óleos vegetais, visando uma maior segurança na manipulação e na ingestão. De fato, existe hoje um considerável interesse na substituição deste solvente por outros solventes alternativos devido a uma crescente preocupação ambiental bem como com a segurança do processo (Hammond et al., 2005).

A Tabela 1.2 apresenta uma compilação dos principais estudos envolvendo a busca por substitutos para a hexana. Os substituintes mais citados são: água com ou sem adição de enzimas, solventes halogenados (diclorometano, tricloroetileno), hidrocarbonetos terpênicos 
(limoneno), cetonas (acetona, butanona, metiletilcetona), fluidos supercríticos (dióxido de carbono), alcoóis (etanol, isopropanol), entre outros.

De maneira geral, a seleção de um solvente para o processo de extração deve levar em conta não somente a segurança da operação, mas também a disponibilidade, eficiência de extração, a qualidade do produto final, o custo, além de toxicidade, bio renovabilidade e grau de periculosidade ao meio ambiente. 
Tabela 1.2 - Solventes alternativos sugeridos para extração de óleos vegetais.

\begin{tabular}{|c|c|c|c|c|}
\hline $\begin{array}{l}\text { Tipo de } \\
\text { solvente }\end{array}$ & $\begin{array}{l}\text { Principais } \\
\text { vantagens }\end{array}$ & $\begin{array}{l}\text { Principais } \\
\text { desvantagens }\end{array}$ & Material & Autor \\
\hline Acetona & $\begin{array}{l}\text { Bom rendimento na } \\
\text { extração do óleo, } \\
\text { gossipol e } \\
\text { aflatoxinas }\end{array}$ & $\begin{array}{l}\text { Escurecimento do óleo } \\
\text { durante o } \\
\text { processamento; odor } \\
\text { desagradável do farelo }\end{array}$ & Algodão & $\begin{array}{l}\text { Vaccarino et al, } 1961 ; \\
\text { Hron e Kuk, } 1989\end{array}$ \\
\hline \multirow{7}{*}{$\begin{array}{l}\text { Água com ou sem } \\
\text { adição de enzimas }\end{array}$} & \multirow{7}{*}{$\begin{array}{l}\text { Solvente não- } \\
\text { inflamável; } \\
\text { Produção de óleo de } \\
\text { boa qualidade }\end{array}$} & \multirow{7}{*}{$\begin{array}{l}\text { Alto custo energético } \\
\text { na etapa de separação } \\
\text { do solvente e secagem } \\
\text { do farelo; Baixo } \\
\text { rendimento }\end{array}$} & Amendoim & $\begin{array}{l}\text { Wang et al., 2008; } \\
\text { Zhang et al., } 2011\end{array}$ \\
\hline & & & $\begin{array}{l}\text { Amendoim e } \\
\text { canola }\end{array}$ & $\begin{array}{l}\text { Do e Sabatini, } 2010 \text {, } \\
2011\end{array}$ \\
\hline & & & $\begin{array}{l}\text { Caroço de } \\
\text { manga, farelo } \\
\text { de arroz e soja }\end{array}$ & Gaur et al., 2007 \\
\hline & & & Farelo de arroz & $\begin{array}{l}\text { Hanmoungjai et al., } \\
\text { 2002; Monsoor et al., } \\
\text { 2003; Monsoor e } \\
\text { Proctor, 2005; } \\
\text { Amarasinghe et al., } \\
2009\end{array}$ \\
\hline & & & $\begin{array}{l}\text { Gérmen de } \\
\text { trigo }\end{array}$ & Li et al., 2011 \\
\hline & & & Girassol & Latif e Anwar, 2009 \\
\hline & & & $\begin{array}{l}\text { Não } \\
\text { especificado }\end{array}$ & Rosenthal et al., 1996 \\
\hline $\begin{array}{l}\text { Aminas primárias, } \\
\text { secundárias e } \\
\text { terciárias }\end{array}$ & $\begin{array}{l}\text { Alto poder de } \\
\text { solubilização do } \\
\text { óleo }\end{array}$ & $\begin{array}{l}\text { Farelo com resíduos } \\
\text { altamente tóxicos }\end{array}$ & Soja & Greenberg et al., 1959 \\
\hline Diclorometano & $\begin{array}{l}\text { Redução de } \\
\text { gossipol e } \\
\text { aflatoxinas no } \\
\text { farelo }\end{array}$ & Poluição ambiental & Algodão & Johnson e Lusas, 1986 \\
\hline
\end{tabular}

Avelã

Ozkal et al., 2005

Alto custo de

Dióxido de carbono supercrítico e propano supercrítico
O processo pode ser conduzido à baixa temperatura investimento; alto custo de produção
Canola

Bulley et al., 1984

Shen et al., 1996; Kuk

Farelo de arroz e Dowd, 1998; Xu e

Godber, 2000

Gergelim

Corso et al., 2010 


\begin{tabular}{|c|c|c|c|c|}
\hline \multicolumn{5}{|c|}{ Tabela 1.2 - Continuação } \\
\hline Tipo de solvente & $\begin{array}{l}\text { Principais } \\
\text { vantagens }\end{array}$ & $\begin{array}{l}\text { Principais } \\
\text { desvantagens }\end{array}$ & Material & Autor \\
\hline \multirow{4}{*}{$\begin{array}{l}\text { Dióxido de } \\
\text { carbono } \\
\text { supercrítico e } \\
\text { propano } \\
\text { supercrítico } \\
\text { (continuação) }\end{array}$} & \multirow{4}{*}{$\begin{array}{l}\text { O processo pode ser } \\
\text { conduzido à baixa } \\
\text { temperatura }\end{array}$} & \multirow{4}{*}{$\begin{array}{l}\text { Alto custo de } \\
\text { investimento; alto } \\
\text { custo de produção }\end{array}$} & $\begin{array}{l}\text { Gérmen de } \\
\text { trigo }\end{array}$ & $\begin{array}{l}\text { Taniguki et al., 1985; } \\
\text { Dunford e Zhang, } \\
2003\end{array}$ \\
\hline & & & $\begin{array}{l}\text { Gordura } \\
\text { animal e } \\
\text { gordura do } \\
\text { leite }\end{array}$ & $\begin{array}{l}\text { Hierro e Santamaria, } \\
1992\end{array}$ \\
\hline & & & $\begin{array}{l}\text { Semente de } \\
\text { uva }\end{array}$ & Sovová et al., 2001 \\
\hline & & & $\begin{array}{l}\text { Soja, girasol e } \\
\text { algodão }\end{array}$ & Stahl et al., 1980 \\
\hline
\end{tabular}

Dióxido de

carbono supercrítico

propano

supercrítico

(continuação) investimento; alto usto de produção
Solvente

\section{Etanol}

reconhecido como seguro (GRAS); biorenovável
Menor poder de solubilização em comparação com a hexana
Magne e Skau, 1953; Rao e Arnold, 1958;

Algodão Hron e Koltun, 1984; Abraham et al., 1991, 1993; Hron et al., 1994

Algodão, amendoim, Rao et al., 1955 gergelim e soja

Kaparthi e Chari,

Amendoim 1959; Fonseca e Regitano-d'Arce, 1993

Avelã

Franco et al., 2009

Babaçu, coco, oliva, palma, colza e girassol

Rao e Arnold, 1956b

Buriti

Ribeiro et al., 2010

Café e girassol Freitas e Lago, 2007

Castanha do Pará

Freitas et al., 2007

Regitano-d'Arce,

Girassol 1985, 1991; Regitano-

d'Arce et al., 1994; Sineiro et al., 1998 


\begin{tabular}{|c|c|c|c|c|}
\hline \multicolumn{5}{|c|}{ Tabela 1.2 - Continuação } \\
\hline Tipo de solvente & $\begin{array}{l}\text { Principais } \\
\text { vantagens } \\
\end{array}$ & $\begin{array}{l}\text { Principais } \\
\text { desvantagens }\end{array}$ & Material & Autor \\
\hline \multirow{6}{*}{$\begin{array}{l}\text { Etanol } \\
\text { (continuação) }\end{array}$} & \multirow{6}{*}{$\begin{array}{l}\text { Solvente } \\
\text { reconhecido como } \\
\text { seguro (GRAS); } \\
\text { biorenovável }\end{array}$} & \multirow{6}{*}{$\begin{array}{l}\text { Menor poder de } \\
\text { solubilização em } \\
\text { comparação com a } \\
\text { hexana }\end{array}$} & Milho & $\begin{array}{l}\text { Kwiatkowski e } \\
\text { Cheryan, 2002; Chien } \\
\text { et al., } 2002\end{array}$ \\
\hline & & & $\begin{array}{l}\text { Milho e } \\
\text { linhaça }\end{array}$ & Rao e Arnold, 1956a \\
\hline & & & Pinhão-manso & $\begin{array}{l}\text { Brossard-Gonzalez et } \\
\text { al., } 2010\end{array}$ \\
\hline & & & $\begin{array}{l}\text { Rosa } \\
\text { rubiginosa }\end{array}$ & Franco et al., 2007 \\
\hline & & & $\begin{array}{l}\text { Semente de } \\
\text { uva }\end{array}$ & Fernandez et al., 2010 \\
\hline & & & Soja & $\begin{array}{l}\text { Beckel et al., 1946, } \\
\text { 1948a; Arnold e } \\
\text { Choudhury, 1962; } \\
\text { Lago et al., 1985; } \\
\text { Silva e Turatti, 1991; } \\
\text { Rittner, 1992; Gandhi } \\
\text { et al., } 2003\end{array}$ \\
\hline \multirow{5}{*}{ Isopropanol } & \multirow{5}{*}{$\begin{array}{l}\text { Pode ser produzido } \\
\text { por rota } \\
\text { biorenovável } \\
\text { (Survase et al., } \\
2011 \text { ); } \\
\text { Maior poder de } \\
\text { solubilização que o } \\
\text { etanol }\end{array}$} & \multirow{5}{*}{$\begin{array}{l}\text { Menor poder de } \\
\text { solubilização em } \\
\text { comparação com a } \\
\text { hexana }\end{array}$} & Algodão & $\begin{array}{l}\text { Harris, et al., 1947, } \\
\text { 1949; Harris e } \\
\text { Hayward, 1950; } \\
\text { Zhang et al., 2002a,b }\end{array}$ \\
\hline & & & Farelo de arroz & $\begin{array}{l}\text { Proctor e Bowen, } \\
\text { 1996; Hu et al., } 1996\end{array}$ \\
\hline & & & Jojoba & Wisniak et al., 1987 \\
\hline & & & Soja & $\begin{array}{l}\text { Baker e Sullivan, } \\
\text { 1983; Seth et al., } 2010\end{array}$ \\
\hline & & & Vários & Rao e Arnold, 1957 \\
\hline Limoneno & $\begin{array}{l}\text { Solvente } \\
\text { reconhecido como } \\
\text { seguro (GRAS); } \\
\text { biorenovável }\end{array}$ & $\begin{array}{l}\text { Alto custo energético } \\
\text { na etapa de separação } \\
\text { do solvente; } \\
\text { Degradação térmica } \\
\text { do solvente durante o } \\
\text { processamento }\end{array}$ & Farelo de arroz & $\begin{array}{l}\text { Mamidipally e Liu, } \\
\text { 2004; } \\
\text { Liu e Mamidipally, } \\
2005\end{array}$ \\
\hline Tricloroetileno & $\begin{array}{l}\text { Alto poder de } \\
\text { solubilização do } \\
\text { óleo; } \\
\text { Não-inflamável }\end{array}$ & $\begin{array}{l}\text { Reação do solvente } \\
\text { com cisteína causando } \\
\text { anemia ao gado } \\
\text { alimentado com o } \\
\text { farelo }\end{array}$ & Soja & $\begin{array}{l}\text { Duncan, 1948; Beckel } \\
\text { et al., 1948b; Arnold e } \\
\text { Ppool, } 1953\end{array}$ \\
\hline & & & & \\
\hline
\end{tabular}




\begin{tabular}{|c|c|c|c|c|}
\hline $\begin{array}{l}\text { Tabela } 1.2-\text { Contin } \\
\text { Tipo de solvente }\end{array}$ & $\begin{array}{l}\text { Principais } \\
\text { vantagens }\end{array}$ & $\begin{array}{l}\text { Principais } \\
\text { desvantagens }\end{array}$ & Material & Autor \\
\hline $\begin{array}{l}\text { Solvente misto } \\
\text { (isohexano e } \\
\text { etanol; isohexano e } \\
\text { isopropanol) }\end{array}$ & $\begin{array}{l}\text { Alto poder de } \\
\text { solubilização do } \\
\text { óleo; } \\
\text { Extração de } \\
\text { gossipol }\end{array}$ & $\begin{array}{l}\text { Dificuldade de } \\
\text { manipulação e } \\
\text { recuperação de } \\
\text { solventes mistos em } \\
\text { atividade industrial }\end{array}$ & Algodão & Kuk e Hron, 1998 \\
\hline $\begin{array}{l}\text { Solvente misto } \\
\text { (etanol com ácido } \\
\text { fosfórico ou } \\
\text { cítrico) }\end{array}$ & $\begin{array}{l}\text { Maximização da } \\
\text { capacidade de } \\
\text { extração de } \\
\text { aflatoxinas além da } \\
\text { extração de gossipol }\end{array}$ & $\begin{array}{l}\text { Dificuldade de } \\
\text { manipulação e } \\
\text { recuperação de } \\
\text { solventes mistos em } \\
\text { atividade industrial }\end{array}$ & Algodão & Hron et al., 1992 \\
\hline $\begin{array}{l}\text { Solvente misto } \\
\text { (hexano com ácido } \\
\text { acético) }\end{array}$ & $\begin{array}{l}\text { Maximização da } \\
\text { capacidade de } \\
\text { extração de lipídeos } \\
\text { e fosfolipideos }\end{array}$ & $\begin{array}{l}\text { Dificuldade de } \\
\text { manipulação e } \\
\text { recuperação de } \\
\text { solventes mistos em } \\
\text { atividade industrial }\end{array}$ & Soja & $\begin{array}{l}\text { Bhagya e Srinivas, } \\
1992\end{array}$ \\
\hline $\begin{array}{l}\text { Solvente misto } \\
\text { (acetona e hexano) }\end{array}$ & $\begin{array}{l}\text { Aumento da } \\
\text { capacidade de } \\
\text { extração de gossipol }\end{array}$ & $\begin{array}{l}\text { Farelo com odor ruim } \\
\text { devido à presença da } \\
\text { acetona }\end{array}$ & Algodão & Kuk et al., 2005 \\
\hline
\end{tabular}

\begin{tabular}{|c|c|c|c|c|}
\hline $\begin{array}{l}\text { Vários (etanol, } \\
\text { hexano e dióxido } \\
\text { de carbono } \\
\text { supercrítico) }\end{array}$ & $\begin{array}{l}\mathrm{CO}_{2} \text { permite } \\
\text { extração de orizanol } \\
\text { e tocoferol; Etanol } \\
\text { permite extração de } \\
\text { orizanol }\end{array}$ & $\begin{array}{l}\text { Etanol e hexano não } \\
\text { extraem tocoferol }\end{array}$ & Farelo de arroz & Imsanguan et al., 2008 \\
\hline $\begin{array}{l}\text { Vários (Isohexano } \\
\text { e heptano) }\end{array}$ & $\begin{array}{l}\text { Maior segurança de } \\
\text { manipulação e } \\
\text { ingestão se } \\
\text { comparado ao } \\
\text { hexano }\end{array}$ & $\begin{array}{l}\text { Baixo ponto de } \\
\text { ebulição do isohexano; } \\
\text { Alto ponto de ebulição } \\
\text { do heptano }\end{array}$ & Algodão & Wan et al., 1995 \\
\hline $\begin{array}{l}\text { Vários (Hexano, } \\
\text { etanol e } \\
\text { isopropanol) }\end{array}$ & $\begin{array}{l}\text { Etanol e } \\
\text { isopropanol são } \\
\text { biorenováveis } \\
\text { (Survase et al., } \\
\text { 2011) }\end{array}$ & $\begin{array}{l}\text { Etanol e isopropanol } \\
\text { são menos voláteis } \\
\text { que hexano, o que } \\
\text { pode aumentar o gasto } \\
\text { energético }\end{array}$ & Algodão & Abraham et al., 1988 \\
\hline
\end{tabular}

Etanol e isopropanol foram estudados na década de 1980 como potenciais substitutos da hexana. Ambos solventes apresentaram viabilidade técnica em termos de rendimento de extração, no entanto, estes solventes não apresentaram viabilidade econômica, naquela oportunidade, nos Estados Unidos da América, região onde ficou concentrada a maior parte dos estudos (Wakelyn e Wan, 2006).

Atualmente, no Brasil, o emprego do etanol como extratante de óleos vegetais torna-se interessante, uma vez que este solvente apresenta grande disponibilidade a baixo custo. Em relação à hexana este solvente apresenta a vantagem de ser menos agressivo ao meio 
ambiente, uma vez que é produzido por via biotecnológica, não gera resíduos tóxicos e é considerado seguro para a saúde humana (solvente GRAS, geralmente reconhecido como seguro).

O item 1.3.2 apresenta um maior detalhamento em relação à utilização do etanol como solvente para óleos vegetais.

\subsubsection{A utilização potencial do etanol como extratante de óleos vegetais}

Estudos de utilização do etanol como solvente para obtenção de óleos vegetais têm sido realizados desde o início do século 20 (Hron et al., 1982; Johnson e Lusas, 1983). É reportado que os japoneses utilizaram industrialmente a extração de óleo de soja com etanol na década de 30 (Sato e Ito, 1932) descontinuando a produção devido ao alto custo do etanol em relação ao hexano.

Na patente de autoria de Sato e Ito (1932) os inventores reportam a possibilidade de utilização de álcool etílico (hidratado ou não) para a solubilização de óleo de soja contido na matriz oleaginosa. Eles descrevem como principal vantagem, tanto operacional como econômica, a separação do solvente do óleo extraído pelo simples resfriamento da miscela.

De maneira geral os trabalhos apresentam dados de solubilidade de óleo vegetal e etanol em diferentes temperaturas (Freitas e Lago, 2007; Freitas et al., 2007; Silva e Turatti, 1991; Regitano-d'Arce, 1991; Regitano-d'Arce, 1985; Rao e Arnold, 1958; Rao e Arnold, 1956b; Rao e Arnold, 1956a; Rao et al., 1955; Magne e Skau, 1953) e comparação entre o método de extração com solvente biorenovável e solvente tradicional (hexana) ou prensagem (Brossard-González et al., 2010; Ribeiro et al., 2010; Ferreira-Dias et al., 2003; Sineiro et al., 1998; Abraham et al., 1988, 1993; Hron e Koltun, 1984).

A Tabela 1.3 apresenta uma compilação dos estudos que empregaram etanol como solvente para óleos vegetais. 
Tabela 1.3 - Estudos desenvolvidos com etanol como solvente alternativo para extração de óleos vegetais.

\begin{tabular}{|c|c|c|c|c|}
\hline $\begin{array}{l}\text { Matéria- } \\
\text { prima }\end{array}$ & $\begin{array}{l}\text { Condições de } \\
\text { processo }\end{array}$ & Objetivos & Principais conclusões & Autor \\
\hline \multirow{8}{*}{ Algodão } & $\begin{array}{l}\text { Etanol } 99,94 \mathrm{e} \\
90 \% / 30^{\circ} \mathrm{C}\end{array}$ & $\begin{array}{l}\text { Estudo do equilíbrio de } \\
\text { fases. Comparação entre } \\
\text { etanol e isopropanol }\end{array}$ & $\begin{array}{l}\text { Solubilidade de óleo no } \\
\text { isopropanol é maior; o } \\
\text { aumento do teor de água no } \\
\text { etanol facilita a separação de } \\
\text { fases }\end{array}$ & $\begin{array}{l}\text { Magne e } \\
\text { Skau, } 1953\end{array}$ \\
\hline & $\begin{array}{l}\text { Etanol 96\% / } 78 \\
{ }^{\circ} \mathrm{C}\end{array}$ & $\begin{array}{l}\text { Determinação de } \\
\text { velocidade de extração }\end{array}$ & $\begin{array}{l}\text { Foi possível a obtenção de } \\
\text { óleo de cor clara e farelo } \\
\text { isento de gossipol }\end{array}$ & $\begin{array}{l}\text { Rao e Arnold, } \\
1958\end{array}$ \\
\hline & $\begin{array}{l}\text { Etanol 95\% / } 79 \\
{ }^{\circ} \mathrm{C}\end{array}$ & $\begin{array}{l}\text { Extração com etanol aliada } \\
\text { à desacidificação com } \\
\text { álcali }\end{array}$ & $\begin{array}{l}\text { Resfriamento da miscela e } \\
\text { desacidificação da fase rica } \\
\text { em óleo com soda cáustica }\end{array}$ & $\begin{array}{l}\text { Hron e } \\
\text { Koltun, } 1984\end{array}$ \\
\hline & $\begin{array}{l}\text { Etanol } 95 \% / 75 \\
{ }^{\circ} \mathrm{C} \text {; } \\
\text { Isopropanol } 91 \% \\
/ 78^{\circ} \mathrm{C} ; \\
\text { Hexano } 60{ }^{\circ} \mathrm{C}\end{array}$ & $\begin{array}{l}\text { Comparação da } \\
\text { solubilidade de óleo em } \\
\text { hexano, isopropanol e } \\
\text { etanol; Cálculo teórico do } \\
\text { número de estágios }\end{array}$ & $\begin{array}{l}\text { Para extração com hexano } \\
\text { são necessários } 7 \text { estágios } \\
\text { enquanto a extração com } \\
\text { etanol ou isopropanol requer } \\
8 \text { estágios }\end{array}$ & $\begin{array}{l}\text { Abraham et } \\
\text { al., } 1988\end{array}$ \\
\hline & $\mathrm{NE}$ & $\begin{array}{l}\text { Estudo teórico para } \\
\text { avaliação econômica }\end{array}$ & $\begin{array}{l}\text { A miscela pobre em óleo } \\
\text { obtida do resfriamento é } \\
\text { purificada por osmose } \\
\text { reversa e é utilizada como } \\
\text { solvente }\end{array}$ & $\begin{array}{l}\text { Abraham et } \\
\text { al., } 1991\end{array}$ \\
\hline & $\begin{array}{l}\text { Etanol } 92 \% \\
\text { Isopropanol } 88 \%\end{array}$ & $\begin{array}{l}\text { Determinação da umidade } \\
\text { crítica (UC) das lâminas de } \\
\text { algodão }\end{array}$ & $\begin{array}{l}\mathrm{UC}=3 \% \text { para etanol } 92 \% \\
\mathrm{UC}=6 \% \text { para isopropanol } \\
88 \%\end{array}$ & $\begin{array}{l}\text { Abraham et } \\
\text { al., } 1993\end{array}$ \\
\hline & Etanol 95\% & $\begin{array}{l}\text { Extração de aflatoxinas e } \\
\text { gossipol em dois estágios }\end{array}$ & $\begin{array}{l}\text { Extração de gossipol com } \\
\text { etanol } 95 \% \text { a temperatura } \\
\text { ambiente e extração de } \\
\text { aflatoxinas e óleo com etanol } \\
\text { a } 78^{\circ} \mathrm{C}\end{array}$ & $\begin{array}{l}\text { Hron et al., } \\
1994\end{array}$ \\
\hline & $\begin{array}{l}\text { Etanol } 99 \% / 15 \\
25,35 \text { e } 45^{\circ} \mathrm{C} \\
\text { Hexano } 15,25 \\
35 \text { e } 45^{\circ} \mathrm{C}\end{array}$ & $\begin{array}{l}\text { Determinação do } \\
\text { rendimento da extração }\end{array}$ & $\begin{array}{l}\text { Os solventes avaliados } \\
\text { apresentaram eficiência de } \\
\text { extração semelhante }\end{array}$ & $\begin{array}{l}\text { Saxena et al., } \\
2011\end{array}$ \\
\hline $\begin{array}{l}\text { Algodão, } \\
\text { amendoim, } \\
\text { gergelim e } \\
\text { soja }\end{array}$ & $\begin{array}{l}\text { Etanol 99, 98, } 95 \\
\text { e } 91,5 \%\end{array}$ & $\begin{array}{l}\text { Determinação de } \\
\text { temperatura crítica }\end{array}$ & $\begin{array}{l}\text { Temperatura crítica aumenta } \\
\text { com o aumento da } \\
\text { hidratação do solvente }\end{array}$ & $\begin{array}{l}\text { Rao et al., } \\
1955\end{array}$ \\
\hline \multirow[b]{2}{*}{ Amendoim } & $\begin{array}{l}\text { Etanol } 95,5 \mathrm{e} \\
98,9 \% / 77^{\circ} \mathrm{C}\end{array}$ & $\begin{array}{l}\text { Torta oriunda da } \\
\text { prensagem foi submetida à } \\
\text { extração com solvente }\end{array}$ & $\begin{array}{l}\text { Etanol } 95,5 \% \text { possibilita } \\
\text { obtenção de óleo de melhor } \\
\text { coloração; sugere-se secar o } \\
\text { sólido (umidade }<1 \% \text { ) }\end{array}$ & $\begin{array}{l}\text { Kaparthi e } \\
\text { Chari, } 1959\end{array}$ \\
\hline & $\begin{array}{l}\text { Etanol 99, 96, } 93 \\
\text { e } 90 \%\end{array}$ & $\begin{array}{l}\text { Comportamento de } \\
\text { aflatoxina B1 adicionada } \\
\text { ao farelo }\end{array}$ & $\begin{array}{l}\text { A eficiência de remoção de } \\
\text { aflatoxinas aumenta com o } \\
\text { aumento da hidratação }\end{array}$ & $\begin{array}{l}\text { Fonseca e } \\
\text { Regitano- } \\
\text { d'Arce, } 1993\end{array}$ \\
\hline (con & & & & \\
\hline
\end{tabular}




\begin{tabular}{|c|c|c|c|c|}
\hline $\begin{array}{l}\text { Matéria- } \\
\text { prima }\end{array}$ & $\begin{array}{l}\text { Condições de } \\
\text { processo }\end{array}$ & Objetivos & Principais conclusões & Autor \\
\hline $\begin{array}{l}\text { Babaçu, } \\
\text { coco, oliva, } \\
\text { palma, colza } \\
\text { e girassol }\end{array}$ & $\begin{array}{l}\text { Etanol 99, 98, } 95 \\
\text { e } 91,5 \%\end{array}$ & $\begin{array}{l}\text { Determinação de } \\
\text { temperatura crítica }\end{array}$ & $\begin{array}{l}\text { Temperatura crítica aumenta } \\
\text { com o aumento da } \\
\text { hidratação do solvente }\end{array}$ & $\begin{array}{l}\text { Rao e Arnold, } \\
1956 b\end{array}$ \\
\hline Buriti & $\begin{array}{l}\text { Etanol 99\% / } 60 \\
{ }^{\circ} \mathrm{C}\end{array}$ & $\begin{array}{l}\text { Determinação do } \\
\text { rendimento da extração }\end{array}$ & $\begin{array}{l}\text { Resfriamento da miscela a } \\
10{ }^{\circ} \mathrm{C} \text { com obtenção de } \\
\text { miscela rica com } 50 \% \text { de } \\
\text { óleo e miscela pobre com } \\
4 \% \text { de óleo }\end{array}$ & $\begin{array}{l}\text { Ribeiro et al., } \\
2010\end{array}$ \\
\hline $\begin{array}{l}\text { Café e } \\
\text { girassol }\end{array}$ & $\begin{array}{l}\text { Etanol } 99,2 \% \text { / } \\
70 \text { e } 75^{\circ} \mathrm{C}\end{array}$ & $\begin{array}{l}\text { Determinação das } \\
\text { concentrações máximas de } \\
\text { óleo nas miscelas }\end{array}$ & $\begin{array}{l}\text { Concentrações máximas de } \\
11,4 \text { e } 18,6 \% \text { para café e } \\
\text { girassol, respectivamente }\end{array}$ & $\begin{array}{l}\text { Freitas e } \\
\text { Lago, } 2007\end{array}$ \\
\hline $\begin{array}{l}\text { Castanha do } \\
\text { Pará }\end{array}$ & $\begin{array}{l}\text { Etanol 99\% / } 65 \\
{ }^{\circ} \mathrm{C}\end{array}$ & $\begin{array}{l}\text { Determinação do } \\
\text { rendimento da extração }\end{array}$ & $\begin{array}{l}\text { Resfriamento da miscela a } \\
10{ }^{\circ} \mathrm{C} \text { com obtenção de } \\
\text { miscela rica com } 60,55 \% \text { de } \\
\text { óleo e miscela pobre com } \\
2,75 \% \text { de óleo }\end{array}$ & $\begin{array}{l}\text { Freitas et al., } \\
2007\end{array}$ \\
\hline \multirow{3}{*}{ Girassol } & $\begin{array}{l}\text { Etanol 90, 93, } 96 \\
\text { e } 99 \% \text { / } \\
\text { Temperatura de } \\
\text { ebulição }\end{array}$ & Rendimento da extração & $\begin{array}{l}\text { Etanol absoluto apresentou } \\
\text { rendimento de extração } \\
\text { similar ao hexano }\end{array}$ & $\begin{array}{l}\text { Regitano- } \\
\text { d'Arce, } 1985\end{array}$ \\
\hline & $\begin{array}{l}\text { Etanol } 90 \text { e } 99 \% \\
\text { / Temperatura de } \\
\text { ebulição }\end{array}$ & $\begin{array}{l}\text { Cinética de extração } \\
\text { Extração de ácido } \\
\text { clorogênico }\end{array}$ & $\begin{array}{l}\text { Etanol hidratado é mais } \\
\text { eficiente na extração do } \\
\text { ácido clorogênico }\end{array}$ & $\begin{array}{l}\text { Regitano- } \\
\text { d'Arce , } 1991\end{array}$ \\
\hline & $\begin{array}{l}\text { Etanol 96\% / } 50 \\
{ }^{\circ} \mathrm{C}\end{array}$ & $\begin{array}{l}\text { Utilização de extrator } \\
\text { pulsado }\end{array}$ & $\begin{array}{l}\text { A utilização de fluxo } \\
\text { pulsado aumenta o } \\
\text { rendimento da extração }\end{array}$ & $\begin{array}{l}\text { Sineiro et al, } \\
1998\end{array}$ \\
\hline \multirow[t]{2}{*}{ Milho } & $\begin{array}{l}\text { Etanol 70, 90, } 95 \\
\text { e } 100 \% / 25,50 \text { e } \\
70^{\circ} \mathrm{C}\end{array}$ & $\begin{array}{l}\text { Otimização do processo de } \\
\text { extração }\end{array}$ & $\begin{array}{l}\text { Extração de material lipídico } \\
\text { para etanol concentrado; } \\
\text { Extração de material não- } \\
\text { lipídico (proteína) para } \\
\text { etanol diluído }\end{array}$ & $\begin{array}{l}\text { Kwiatkowski } \\
\text { e Cheryan, } \\
2002\end{array}$ \\
\hline & $\begin{array}{l}\text { Etanol } 85 \mathrm{a} \\
100 \% / 25,50 \mathrm{e} \\
68^{\circ} \mathrm{C}\end{array}$ & $\begin{array}{l}\text { Determinação de isoterma } \\
\text { de equilíbrio de extração } \\
\text { de óleo }\end{array}$ & $\begin{array}{l}\text { O rendimento da extração } \\
\text { aumenta com o aumento da } \\
\text { temperatura e concentração } \\
\text { do etanol }\end{array}$ & $\begin{array}{l}\text { Chien et al., } \\
2002\end{array}$ \\
\hline $\begin{array}{l}\text { Milho e } \\
\text { linhaça }\end{array}$ & $\begin{array}{l}\text { Etanol 99, 98, } 95 \\
\text { e } 91,5 \%\end{array}$ & $\begin{array}{l}\text { Determinação de } \\
\text { temperatura crítica }\end{array}$ & $\begin{array}{l}\text { Temperatura crítica aumenta } \\
\text { com o aumento da } \\
\text { hidratação do solvente }\end{array}$ & $\begin{array}{l}\text { Rao e Arnold, } \\
1956 \text { a }\end{array}$ \\
\hline $\begin{array}{l}\text { Rosa } \\
\text { rubiginosa }\end{array}$ & $\begin{array}{l}\text { Etanol } 92,96 \text { e } \\
99 \% / 20,3040 \\
50 \text { e } 70{ }^{\circ} \mathrm{C}\end{array}$ & $\begin{array}{l}\text { Determinação do } \\
\text { equilíbrio de solubilidade e } \\
\text { cinética de extração }\end{array}$ & $\begin{array}{l}\text { Os autores sugerem o uso de } \\
\text { etanol hidratado devido ao } \\
\text { alto custo do etanol absoluto }\end{array}$ & $\begin{array}{l}\text { Franco et al., } \\
2007\end{array}$ \\
\hline $\begin{array}{l}\text { Pinhão- } \\
\text { manso }\end{array}$ & $\begin{array}{l}\text { Etanol 99,5\% / } \\
60-70{ }^{\circ} \mathrm{C} \\
\text { Hexano } 98,5 \% \text { / } \\
50-60{ }^{\circ} \mathrm{C} \\
\text { Prensagem } 70, \\
85 \text { e } 100{ }^{\circ} \mathrm{C}\end{array}$ & $\begin{array}{l}\text { Comparação entre os dois } \\
\text { métodos de obtenção do } \\
\text { óleo, prensagem e solvente }\end{array}$ & $\begin{array}{l}\text { A utilização de etanol como } \\
\text { solvente possibilita maior } \\
\text { rendimento que a } \\
\text { prensagem. } \\
\text { A composição dos óleos } \\
\text { obtidos, em termos de ácidos } \\
\text { graxos, foi semelhante }\end{array}$ & $\begin{array}{l}\text { Brossard- } \\
\text { Gonzalez et } \\
\text { al., } 2010\end{array}$ \\
\hline & & & & \\
\hline
\end{tabular}




\begin{tabular}{|c|c|c|c|c|}
\hline \multicolumn{5}{|c|}{ Tabela 1.3 - Continuação } \\
\hline $\begin{array}{l}\text { Matéria- } \\
\text { prima }\end{array}$ & $\begin{array}{l}\text { Condições de } \\
\text { processo }\end{array}$ & Objetivos & Principais conclusões & Autor \\
\hline $\begin{array}{l}\text { Semente de } \\
\text { uva }\end{array}$ & $\begin{array}{l}\text { Hexano, pentano, } \\
\text { acetona, } \\
\text { acetonitrila, éter } \\
\text { etílico, metanol, } \\
\text { etanol e } \\
\text { solventes mistos } \\
\text { (hexano/metanol, } \\
\text { hexano/acetona, } \\
\text { hexano/clorofór } \\
\text { mio) }\end{array}$ & $\begin{array}{l}\text { Comparação entre os dois } \\
\text { métodos de obtenção do } \\
\text { óleo, prensagem e } \\
\text { solvente. Comparação } \\
\text { entre diversos tipos de } \\
\text { solventes. }\end{array}$ & $\begin{array}{l}\text { Etanol possibilitou extração } \\
\text { de óleo com alta estabilidade } \\
\text { oxidativa }\end{array}$ & $\begin{array}{l}\text { Fernandez et } \\
\text { al., } 2010\end{array}$ \\
\hline \multirow{7}{*}{ Soja } & $\begin{array}{l}\text { Hexano } 30^{\circ} \mathrm{C} \\
\text { Etanol } 99,9 \% / \\
78^{\circ} \mathrm{C} \text {; } \\
\text { Isopropanol } \\
99,9 \% / 82^{\circ} \mathrm{C}\end{array}$ & $\begin{array}{l}\text { Montagem de equipamento } \\
\text { de laboratório para } \\
\text { extração de óleo }\end{array}$ & $\begin{array}{l}\text { A razão solvente: sólido de } \\
\text { 2,12: } 1 \text { possibilitou } 0,62 \% \text { de } \\
\text { óleo residual no farelo } \\
\text { quando etanol foi utilizado }\end{array}$ & $\begin{array}{l}\text { Beckel et al., } \\
1946\end{array}$ \\
\hline & $\begin{array}{l}\text { Etanol 95\% / } 78 \\
{ }^{\circ} \mathrm{C}\end{array}$ & $\begin{array}{l}\text { Estudo da recuperação do } \\
\text { solvente por resfriamento } \\
\text { da miscela }\end{array}$ & $\begin{array}{l}\text { Economia de calor sensível; } \\
\text { utilização de } 7 / 10 \text { da energia } \\
\text { requerida para o processo } \\
\text { com hexana }\end{array}$ & $\begin{array}{l}\text { Beckel et al., } \\
1948 \text { a }\end{array}$ \\
\hline & NE & $\begin{array}{l}\text { Estudo comparativo entre } \\
\text { etanol, isopropanol, } \\
\text { isobutanol, dicloroetano, } \\
\text { tricloroetileno, tetracloreto } \\
\text { de carbono e hexano }\end{array}$ & $\begin{array}{l}\text { O etanol forneceu óleo com } \\
\text { boa coloração e farelo de boa } \\
\text { qualidade }\end{array}$ & $\begin{array}{l}\text { Beckel et al., } \\
1948 b\end{array}$ \\
\hline & $\begin{array}{l}\text { Etanol 99, 98, } 95 \\
\text { e } 90 \% / 71^{\circ} \mathrm{C}\end{array}$ & $\begin{array}{l}\text { Monitoramento de cor e } \\
\text { índice de iodo do óleo } \\
\text { extraído }\end{array}$ & $\begin{array}{l}\text { Foi observada pequena } \\
\text { diferença na qualidade do } \\
\text { óleo extraído com os } \\
\text { solventes com diferentes } \\
\text { teores de água }\end{array}$ & $\begin{array}{l}\text { Arnold e } \\
\text { Choudhury, } \\
1962\end{array}$ \\
\hline & $\begin{array}{l}\text { Etanol 88, } 91 \text { e } \\
94 \% / 66,70 \text { e } 74 \\
{ }^{\circ} \mathrm{C}\end{array}$ & Rendimento da extração & $\begin{array}{l}\text { Aumento da extração de } \\
\text { material não lipídico com } \\
\text { diminuição da concentração } \\
\text { do etanol; apontou } \\
\text { dificuldade na etapa de } \\
\text { dessolventização do farelo }\end{array}$ & $\begin{array}{l}\text { Silva e } \\
\text { Turatti, } 1991\end{array}$ \\
\hline & $\mathrm{NE}$ & $\begin{array}{l}\text { Avaliação teórica do } \\
\text { processo de substituição de } \\
\text { hexano por etanol }\end{array}$ & $\begin{array}{l}\text { Sugere a utilização de } \\
\text { extratores em batelada } \\
\text { devido à pressurização do } \\
\text { sistema }\end{array}$ & Rittner, 1992 \\
\hline & $\mathrm{NE}$ & $\begin{array}{l}\text { Avaliação de diversos } \\
\text { solventes: etanol, iso e n- } \\
\text { propanol, heptano, hexano; } \\
\text { alcoóis hidratados e } \\
\text { misturas azeotrópicas de } \\
\text { hexano ou heptano e } \\
\text { alcoóis }\end{array}$ & $\begin{array}{l}\text { A composição dos óleos e } \\
\text { farelos obtidos com os } \\
\text { diferentes solventes foi } \\
\text { similar aos obtidos com } \\
\text { hexano }\end{array}$ & $\begin{array}{l}\text { Gandhi et al., } \\
2003\end{array}$ \\
\hline
\end{tabular}

NE: não especificado.

Com base nas informações apresentadas na Tabela 1.3, pode-se inferir que a maioria dos trabalhos realizados com etanol abordou o tema com base na comparação entre os valores 
de rendimento de extração possibilitados pelo solvente alternativo e pelos métodos tradicionais, extração com hexano ou prensagem.

De fato, percebe-se que um estudo sistematizado que compreenda, não somente o impacto das variáveis operacionais nas características dos produtos, mas também a avaliação de possíveis mudanças no projeto de equipamentos e na configuração do processo de obtenção de óleos vegetais como um todo é extremamente relevante.

Uma variável de projeto que deve ser estudada para permitir a correta avaliação da viabilidade da mudança de solvente é o índice de retenção, o qual é definido como a quantidade de solução que fica aderida ao material insolúvel após o processo de extração (liquid hold-up) (Takeuchi et al., 2009).

O valor do índice de retenção impacta de forma decisiva no número de estágios necessários para realizar a extração (volume do extrator) e, também, na etapa de recuperação do solvente aderido ao farelo desengordurado (etapa de dessolventização). De maneira geral, a retenção depende da viscosidade da solução extrato e da afinidade físico-química entre a solução e a matriz sólida (Wisniak et al., 1987).

Em estudo sobre a extração de óleo de jojoba utilizando hexano e isopropanol, Wisniak et al. (1987) mostraram que os valores de índice de retenção para o solvente isopropanol são sempre superiores aos obtidos para o solvente hexano.

Outro aspecto importante que deve ser levado em conta é o comportamento dos compostos lipídicos minoritários durante o processo de extração com solvente alternativo. Estudos recentes mostram testes comparativos entre hexano, isopropanol, acetato de etila, metanol, diclorometano, acetonitrila e ácido acético na extração do óleo de farelo de arroz (Imsanguan et al., 2008; Xu e Godber, 2000; Proctor e Bowen, 1996; Hu et al., 1996). Em linhas gerais, os estudos mostram uma capacidade similar de extração de óleo e de orizanol, comparando-se os resultados obtidos para hexano e isopropanol, e uma maior capacidade de extração de vitamina E para este último tipo de solvente (Hu et al., 1996). A maior capacidade de extração de vitaminas apresentada pelo isopropanol pode ser responsável pelo maior estabilidade oxidativa do óleo obtido via isopropanol (Proctor e Bowen, 1996).

Ainda no contexto do comportamento dos compostos minoritários, Regitano-d'Arce (1991, 1985) avaliou a influência da hidratação do solvente etanol na extração do ácido clorogênico. A autora observou que a extração do composto fenólico aumentou com o aumento da hidratação do solvente enquanto a miscela pobre, ou seja, a fase rica em solvente resultante do abaixamento da temperatura foi enriquecida em tocoferóis (Regitano-d'Arce, 1991, 1985). 
Além destes aspectos, a característica apresentada pelo etanol de apresentar alta solubilidade de triacilgliceróis a elevada temperatura e baixa solubilidade a temperatura ambiente, possibilitando a separação das fases oleosa e solvente sem a necessidade de evaporação/destilação, deve ser totalmente explorada.

De maneira geral, pode-se inferir que a característica de miscibilidade parcial entre óleo vegetal e etanol abre uma possibilidade adicional de se aliar a extração alcoólica à técnica de desacidificação de óleos vegetais por extração líquido-líquido. De fato, sugere-se que a mistura óleo - solvente, oriunda do extrator sólido-líquido, seja resfriada com a subsequente formação de duas fases líquidas, possibilitando nesta etapa uma pré-recuperação do solvente sem gasto energético. Em seguida, a fase rica em óleo é submetida ao processo de desacidificação por extração líquido-líquido.

Aspectos relevantes em relação a este processo alternativo de refino de óleos vegetais são discutidos no item a seguir.

\subsection{Processos de refino de óleos vegetais}

Refino é um termo genérico utilizado para denominar as etapas de purificação dos óleos vegetais brutos com o intuito de remover substâncias indesejáveis. Resumidamente, as etapas que compõem o processamento de óleos vegetais são: preparação e extração mecânica e/ou com solvente, degomagem, branqueamento, desacidificação por via física (refino físico) ou por adição de soda cáustica (refino químico ou alcalino) e desodorização. A Figura 1.6 apresenta de forma simplificada as principais etapas de purificação que compõem a produção de óleos vegetais comestíveis. 


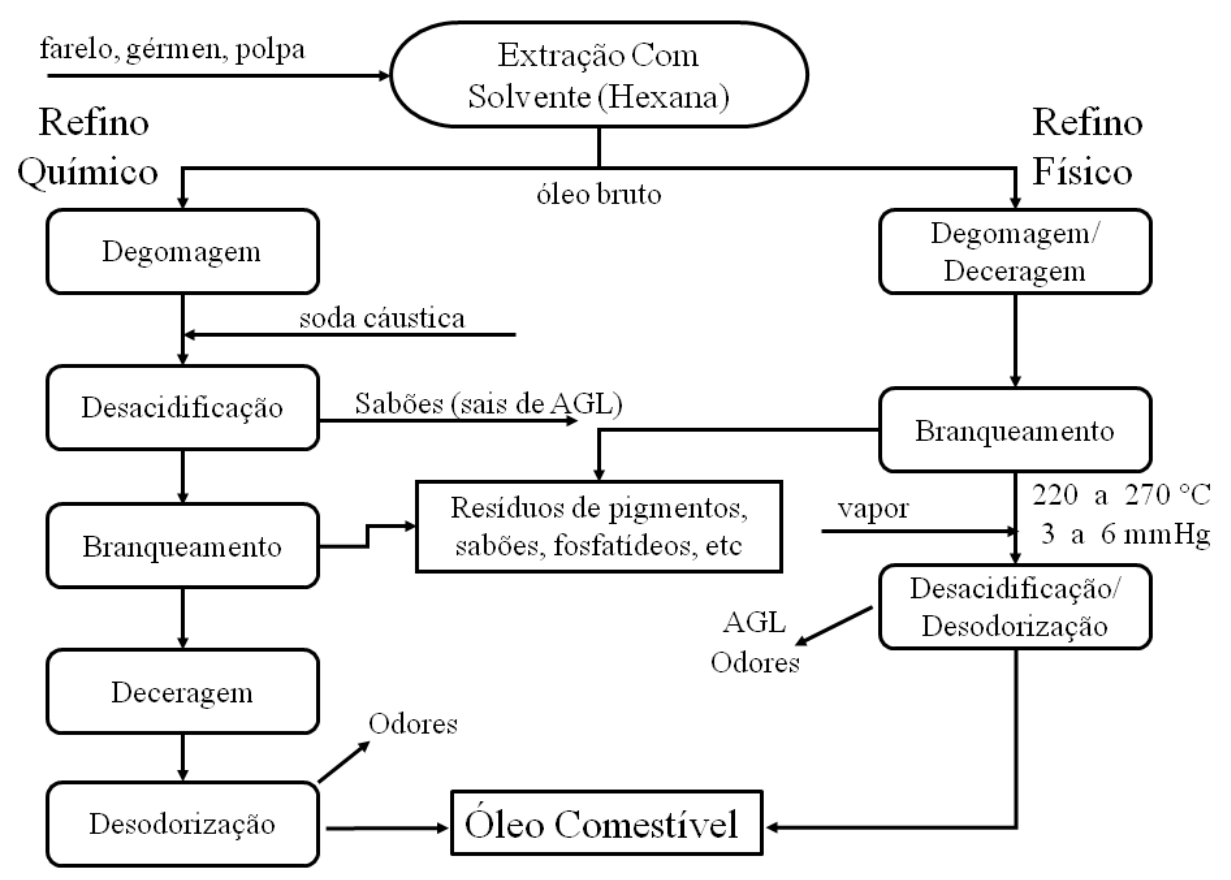

Figura 1.6 - Etapas de purificação na produção de óleos vegetais comestiveis.

A remoção dos ácidos graxos livres (desacidificação) é o passo mais importante do processo de refino, principalmente porque o rendimento do óleo neutro nesta etapa tem um efeito significativo no custo do processo.

Além da remoção dos ácidos graxos livres, os processos de refino visam à remoção de fosfolipídios, pigmentos, ceras e traços de metais. Entretanto, a permanência no óleo refinado de algumas substâncias tais como esteróis, tocoferóis e tocotrienóis é altamente desejável devido a suas características antioxidantes e com valor de vitamina (Kim et al., 1985).

A desacidificação, ou seja, a remoção dos ácidos graxos livres tem sido realizada, predominantemente, por neutralização destes compostos com soda cáustica, no denominado refino químico, convertendo-os em sabões, os quais são insolúveis no óleo na temperatura de operação, sendo removidos posteriormente por meio de centrifugação ou decantação. A temperatura de operação pode variar de 50 a $90{ }^{\circ} \mathrm{C}$ dependendo da composição do óleo e do álcali utilizado (Wakelyn e Wan, 2006; Antoniassi et al., 1998; Hartman, 1971).

O refino químico é um processo versátil e bem conhecido que pode ser aplicado para qualquer óleo bruto, porém, quanto maior a porcentagem de ácidos graxos livres no óleo bruto, maior a perda de óleo neutro, a qual ocorre devido à saponificação e alta emulsibilidade do óleo no sabão formado (Antoniassi et al., 1998). As perdas de óleo neutro, para óleos brutos de milho com conteúdos de ácidos graxos livres entre 8 e 14\%, podem atingir de 15 a 25\%, no refino alcalino, de acordo com Leibovitz e Ruckenstein (1983) e cerca de 14\%, em refinarias brasileiras, para óleos com 4\% de acidez (Antoniassi et al., 1998). 
Além do refino químico, algumas refinarias têm utilizado o processo denominado refino físico para a desacidificação de óleos. Neste tipo de procedimento as etapas de branqueamento, desodorização e desacidificação ocorrem conjuntamente pela ação de elevadas temperaturas, que causam a degradação térmica e a volatilização de compostos. De fato, este processo baseia-se na diferença considerável entre os pontos de ebulição dos ácidos graxos livres (AGL) e dos triacilgliceróis (TAG) nas condições de operação, as quais requerem baixas pressões, 3 a $6 \mathrm{mmHg}$, e altas temperaturas, de 220 a $270{ }^{\circ} \mathrm{C}$, dependendo do óleo (Antoniassi et al., 1998; Hartman, 1971).

O refino físico pode ser economicamente vantajoso para óleos com altos teores de ácidos graxos livres, entretanto, este tipo de processo só é aplicável para óleos com baixo teor de fosfolipídios (ou que tenham passado pela etapa de remoção destes compostos, etapa de degomagem, apresentando no máximo $10 \mathrm{mg} / \mathrm{kg}$ de fosfolipídios) e para óleos onde as condições extremas de operação, baixas pressões e altas temperaturas, não tenham impacto negativo na qualidade final do produto (Antoniassi et al., 1998). A desacidificação pelo método físico não é tão efetiva quanto à desacidificação alcalina (Carr, 1978) e a qualidade do produto final é sempre determinada pela qualidade do óleo bruto (Cvengros, 1995). Por outro lado, o refino físico apresenta como principal vantagem, em relação ao refino químico, o baixo consumo de água e pequena geração de efluentes.

Em relação ao óleo de farelo de arroz (OFA), o refino geralmente consiste das etapas de deceragem, degomagem, desacidificação por neutralização com álcali (refino químico), branqueamento e desodorização (Orthoefer, 2005), no entanto algumas refinarias nos Estados Unidos, Japão e Brasil utilizam o método físico para refino deste óleo. De acordo com Orthoefer (1996), as perdas de óleo neutro no refino químico do OFA são consideravelmente altas se comparadas a outros óleos vegetais com conteúdos similares de ácidos graxos livres (12 a 40\% para óleo bruto com 5\% de acidez livre). Este fato é devido, principalmente, ao efeito sinergético das ceras e do $\gamma$-orizanol que maximiza a perda de óleo neutro, assim como a presença de ésteres parciais e compostos oxidados (Orthoefer, 2005; Mishira et al., 1988; Krishna, 1993).

O método químico de desacidificação é o mais empregado para o refino do óleo de soja, com ou sem etapa prévia de degomagem. De fato, o óleo de soja pode apresentar altos teores de fosfolipídios, fator que dificulta o emprego do refino físico uma vez que estes compostos, sob as condições extremas de temperatura, podem causar o escurecimento do óleo e a geração de odores desagradáveis (Hammond et al., 2005). A neutralização com álcali, além de eliminar os ácidos graxos livres através da reação de saponificação, promove a 
remoção de pigmentos naturais, fosfolipídios e substâncias mucilaginosas por adsorção no sabão formado.

Processos alternativos para desacidificação de óleos vegetais têm sido sistematicamente propostos na literatura. A Tabela 1.4 apresenta as principais contribuições relativas a cada tecnologia.

Um processo alternativo de desacidificação de óleos vegetais é a técnica por extração líquido-líquido. A razão potencial deste processo está no fato de consumir menor quantidade de energia, pois é realizado a temperatura ambiente e pressão atmosférica. Estas condições brandas de operação são, também, muito favoráveis para óleos que não aceitam as temperaturas altas do refino físico $\left(220\right.$ a $\left.270{ }^{\circ} \mathrm{C}\right)$ (Hamm, 1983). Além da economia de energia, a extração líquido-líquido apresenta vantagem em relação ao refino químico, pois não gera sabões e minimiza a perda de óleo neutro (Rodrigues, 2004; Rodrigues et al., 2007a).

Tabela 1.4 - Métodos alternativos de desacidificação de óleos vegetais.

\begin{tabular}{|c|c|c|}
\hline Método & Fundamento / Características & Autor \\
\hline \multirow[b]{2}{*}{$\begin{array}{l}\text { Desacidificação } \\
\text { biológica ou } \\
\text { biorefino }\end{array}$} & $\begin{array}{l}\text { Microorganismos removem e/ou assimilam AGL } \\
\text { para seu próprio crescimento }\end{array}$ & $\begin{array}{l}\text { Cho et al., 1990; Bhosle e } \\
\text { Subramanian, } 2005\end{array}$ \\
\hline & $\begin{array}{l}\text { Lipases esterificam os AGL com os grupos } \\
\text { hidroxila já presentes no óleo ou em grupos } \\
\text { hidroxila de substâncias adicionadas, como o } \\
\text { glicerol }\end{array}$ & Sengupta e Bhattacharyya, 1992 \\
\hline $\begin{array}{l}\text { Extração líquido- } \\
\text { líquido }\end{array}$ & $\begin{array}{l}\text { Diferença de solubilidade dos AGL e dos TAG em } \\
\text { um solvente apropriado }\end{array}$ & $\begin{array}{l}\text { Thomopoulos, 1971; Pina e } \\
\text { Meirelles, 2000; Rodrigues, 2004; } \\
\text { Rodrigues et al., 2007a; Meirelles } \\
\text { et al., } 2009\end{array}$ \\
\hline $\begin{array}{l}\text { Fluido supercrítico } \\
\left(\mathrm{CO}_{2}\right)\end{array}$ & $\begin{array}{l}\text { Alta seletividade, baixa perda de óleo neutro e } \\
\text { pode ser conduzido sob condições amenas de } \\
\text { temperatura }\end{array}$ & $\begin{array}{l}\text { Manan et al., 2009; Vaszquez et } \\
\text { al., } 2009\end{array}$ \\
\hline Membranas & $\begin{array}{l}\text { Separação com base na diferença entre as massas } \\
\text { molares dos AGL e TAG. Processo com ou sem a } \\
\text { utilização de solventes; membranas porosas ou } \\
\text { não-porosas }\end{array}$ & $\begin{array}{l}\text { Jala et al., 2011; Coutinho et al., } \\
2009\end{array}$ \\
\hline $\begin{array}{l}\text { Reesterificação } \\
\text { química }\end{array}$ & $\begin{array}{l}\text { Reesterificação dos AGL sob condições de alta } \\
\text { temperatura, atmosfera inerte, com ou sem o uso } \\
\text { de catalisadores }\end{array}$ & $\begin{array}{l}\text { Ebewele et al., 2010; Gingras, } \\
2000\end{array}$ \\
\hline $\begin{array}{l}\text { Resinas de troca } \\
\text { iônica }\end{array}$ & $\begin{array}{l}\text { Resinas básicas: adsorção dos AGL nos sítios de } \\
\text { caráter básico. Resinas ácidas: esterificação dos } \\
\text { AGL nos sítios, na presença de etanol ou metanol, } \\
\text { produzindo biodiesel }\end{array}$ & $\begin{array}{l}\text { Jamal e Boulanger, 2010; Pirola et } \\
\text { al., 2010; Cren et al., 2009, 2010; } \\
\text { Cren e Meirelles, } 2005\end{array}$ \\
\hline
\end{tabular}

No contexto deste trabalho de pesquisa, a técnica de extração líquido-líquido (ELL) apresenta uma vantagem adicional em relação aos outros processos citados na Tabela 1.4 e, também, em relação aos processos tradicionais. 
A técnica de desacidificação por ELL poderia ser associada à etapa de extração do óleo com etanol, pois, de acordo com trabalhos publicados na literatura, o etanol é um solvente capaz de extrair seletivamente ácidos graxos livres presentes no óleo durante o contato entre as fases líquidas óleo e solvente. Desta forma, após a etapa de extração sólidolíquido, com subsequente abaixamento da temperatura e geração de duas fases líquidas, seria possível conduzir a etapa de remoção dos AGL, também utilizando o solvente biorenovável.

\subsubsection{Desacidificação de óleos vegetais por extração líquido-líquido utilizando etanol como solvente}

De acordo com Thomopoulos (1971), a diferença de solubilidade dos ácidos graxos livres e dos triacilgliceróis neutros em um solvente apropriado é a base da extração líquidolíquido aplicada a desacidificação de óleos vegetais. Outro aspecto relevante é a facilidade de recuperação posterior do solvente, presente nas fases extrato e rafinado, para sua reutilização no processo. Estas etapas subsequentes de processamento são facilitadas devido à diferença entre os pontos de ebulição do solvente, dos triacilgliceróis e dos ácidos graxos livres (Pina e Meirelles, 2000).

Dados experimentais de equilíbrio de fases de sistemas compostos por óleos vegetais, ácidos graxos livres e solventes são necessários para o correto projeto de equipamentos dedicados a desacidificação de óleos por extração líquido-líquido em escala industrial.

Na Tabela 1.5 estão mostrados os estudos mais relevantes relacionados à desacidificação de óleos por extração líquido-líquido (ELL) utilizando diferentes solventes. 
Tabela 1.5 - Solventes propostos para desacidificação de óleos vegetais por ELL.

\begin{tabular}{|c|c|c|c|}
\hline Óleo & Solvente & Temperatura & Autor \\
\hline Algodão & Etanol com 0, 6, 12 e $19 \%$ de água & $25^{\circ} \mathrm{C}$ & $\begin{array}{l}\text { Rodrigues et } \\
\text { al., } 2005 \mathrm{a}\end{array}$ \\
\hline $\begin{array}{l}\text { Alho, } \\
\text { semente de } \\
\text { uva e } \\
\text { gergelim }\end{array}$ & Etanol com $0,6,12$ e $18 \%$ de água & $25^{\circ} \mathrm{C}$ & $\begin{array}{l}\text { Rodrigues et } \\
\text { al., } 2006 \mathrm{a}\end{array}$ \\
\hline $\begin{array}{l}\text { Amendoim e } \\
\text { caroço de } \\
\text { abacate }\end{array}$ & Etanol com 0,6 e $12 \%$ de água & $25^{\circ} \mathrm{C}$ & $\begin{array}{l}\text { Rodrigues e } \\
\text { Meirelles, } 2008\end{array}$ \\
\hline Babaçu & Etanol com $0,5,10,20$ e $30 \%$ de água & $30^{\circ} \mathrm{C}$ & $\begin{array}{l}\text { Reipert et al., } \\
2011\end{array}$ \\
\hline Canola & $\begin{array}{l}\text { Metanol, etanol, isopropanol, n-propanol e etanol com } \\
5 \% \text { de água }\end{array}$ & 20 e $30^{\circ} \mathrm{C}$ & $\begin{array}{l}\text { Batista et al., } \\
\text { 1999a }\end{array}$ \\
\hline $\begin{array}{l}\text { Castanha do } \\
\text { Pará e } \\
\text { macadâmia }\end{array}$ & Etanol com 0,6 e $12 \%$ de água & $25^{\circ} \mathrm{C}$ & $\begin{array}{l}\text { Rodrigues et } \\
\text { al., } 2005 b\end{array}$ \\
\hline \multirow{2}{*}{$\begin{array}{l}\text { Farelo de } \\
\text { arroz }\end{array}$} & Etanol com $0,2,6,10$ e $12 \%$ de água & $25^{\circ} \mathrm{C}$ & $\begin{array}{l}\text { Rodrigues et } \\
\text { al., } 2003\end{array}$ \\
\hline & Etanol com $0,3,6,10$ e $12 \%$ de água & $25^{\circ} \mathrm{C}$ & $\begin{array}{l}\text { Rodrigues et } \\
\text { al., } 2004\end{array}$ \\
\hline \multirow{3}{*}{ Girassol } & Etanol e metanol & 30 e $40{ }^{\circ} \mathrm{C}$ & $\begin{array}{l}\text { Mohsen-Nia e } \\
\text { Khodayari, } \\
2008\end{array}$ \\
\hline & Etanol com $0,5,18$ e $29 \%$ água & 10,25 e $60^{\circ} \mathrm{C}$ & $\begin{array}{l}\text { Cuevas et al., } \\
2009\end{array}$ \\
\hline & Etanol com $0,6,12$ e $18 \%$ água & $25^{\circ} \mathrm{C}$ & $\begin{array}{l}\text { Cuevas et al., } \\
2010\end{array}$ \\
\hline \multirow{3}{*}{ Milho } & Etanol com $5,8,12$ e $18 \%$ de água & $25^{\circ} \mathrm{C}$ & $\begin{array}{l}\text { Gonçalves et } \\
\text { al., } 2002\end{array}$ \\
\hline & Etanol e metanol & 30 e $40^{\circ} \mathrm{C}$ & $\begin{array}{l}\text { Mohsen-Nia e } \\
\text { Dargahi, } 2007\end{array}$ \\
\hline & Etanol com 5\% água & 25,35 e $45^{\circ} \mathrm{C}$ & $\begin{array}{l}\text { Mohsen-Nia et } \\
\text { al., } 2007\end{array}$ \\
\hline $\begin{array}{l}\text { Oleína e } \\
\text { estearina de } \\
\text { palma }\end{array}$ & Etanol com 0,5 e $10 \%$ de água & 25,45 e $50^{\circ} \mathrm{C}$ & $\begin{array}{l}\text { Silva et al., } \\
2011\end{array}$ \\
\hline Palma & Etanol com 0,6 e $12 \%$ de água & $45^{\circ} \mathrm{C}$ & $\begin{array}{l}\text { Gonçalves e } \\
\text { Meirelles, } 2004\end{array}$ \\
\hline $\begin{array}{l}\text { Pinhão } \\
\text { manso }\end{array}$ & Etanol com 0,2 e $4 \%$ de água & $\begin{array}{l}15,25,35 \text { e } 45 \\
{ }^{\circ} \mathrm{C}\end{array}$ & $\begin{array}{l}\text { Silva et al., } \\
2010 \text { b }\end{array}$ \\
\hline $\begin{array}{l}\text { Semente de } \\
\text { uva }\end{array}$ & Etanol com 0,4 e 5,58\% de água & $10,17,5$ e $25^{\circ} \mathrm{C}$ & $\begin{array}{l}\text { Sanaiotti et al., } \\
2008\end{array}$ \\
\hline \multirow{2}{*}{ Soja } & Etanol com $0,5,18$ e $30 \%$ água & $50^{\circ} \mathrm{C}$ & $\begin{array}{l}\text { Rodrigues et } \\
\text { al., 2007b }\end{array}$ \\
\hline & Etanol com $5,10,15$ e $18 \%$ água & $30^{\circ} \mathrm{C}$ & $\begin{array}{l}\text { Mohsen-Nia et } \\
\text { al., } 2008\end{array}$ \\
\hline
\end{tabular}




\begin{tabular}{|c|c|c|c|}
\hline \multicolumn{4}{|c|}{ Tabela 1.5 - Continuação } \\
\hline Óleo & Solvente & Temperatura & Autor \\
\hline \multirow{3}{*}{$\begin{array}{l}\text { Soja } \\
\text { (continuação) }\end{array}$} & Etanol com $0,5,18$ e $30 \%$ água & 25,30 e $50^{\circ} \mathrm{C}$ & $\begin{array}{l}\text { Chiyoda et al., } \\
2010\end{array}$ \\
\hline & Etanol com $5,8,11$ e $14 \%$ água & $25^{\circ} \mathrm{C}$ & $\begin{array}{l}\text { Sanaiotti et al., } \\
2010\end{array}$ \\
\hline & Líquidos iônicos ou polietilenoglicol & 25,50 e $70^{\circ} \mathrm{C}$ & $\begin{array}{l}\text { Manic et al., } \\
2011\end{array}$ \\
\hline Soja e jojoba & $\begin{array}{l}\text { Formamida, n-metilformamida, n-dimetilformamida, } \\
\text { dimetilsulfóxido, 1,2-butanodiol, e 2-buteno-1,4-diol }\end{array}$ & $25^{\circ} \mathrm{C}$ & $\begin{array}{l}\text { Apelblat et al., } \\
1996\end{array}$ \\
\hline
\end{tabular}

Diversos tipos de solventes têm sido sugeridos na literatura (Manic et al., 2011; Mohsen-Nia e Dargahi, 2007; Batista et al., 1999a; Apelblat et al., 1996) sendo que os alcoóis de cadeia curta, com destaque para o etanol, apresentam os resultados mais promissores. De fato, o etanol é sugerido como o melhor solvente para o processo devido apresentar baixa toxicidade, facilidade de recuperação e bons valores de seletividade e coeficiente de distribuição para os ácidos graxos livres.

Com o objetivo de se aliar a técnica de ELL à etapa de extração do óleo da matriz sólida, a verificação do comportamento de outras variáveis dependentes, além da partição dos ácidos graxos livres, faz-se necessária para permitir uma configuração ótima do processo. É necessário conhecer como a partição dos ácidos graxos livres e dos compostos minoritários de interesse, compostos vitamínicos e antioxidantes, é influenciada pela temperatura de processo, por exemplo.

Estas informações, aliadas ao estudo da recuperação do solvente pelo resfriamento da fase extrato permitirão aperfeiçoar o processo integrado de extração e desacidificação de óleos vegetais utilizando etanol como solvente. 
CATÍtULO 2

MATERIAIS E MÉTODOS 


\subsection{Material e Métodos}

\subsubsection{Material}

- $\quad$ Soja laminada (Cargill, Mairinque / SP, Brasil)

- $\quad$ Farelo de arroz em pellets (Irgovel/Nutracea, Pelotas / RS, Brasil)

- $\quad$ Óleo de farelo de arroz degomado (Irgovel/Nutracea, Pelotas / RS, Brasil)

- $\quad$ Óleo de soja degomado (Cargill, Mairinque / SP, Brasil)

\subsubsection{Reagentes}

- $\quad$ Etanol absoluto (Merck, Darmstadt, Alemanha, min 99,8\%)

- $\quad$ Etanol Hidratado (Merck, Darmstadt, Alemanha, min. 96\%)

- $\quad$ Etanol Hidratado (Ecibra, São Paulo / SP, Brasil, min. 95\%)

- $\quad$ Éter Etílico para análise (Vetec, Rio de Janeiro / RJ, Brasil)

- $\quad$ Hidróxido de Sódio (J T Baker, Phillipsburg, EUA)

- $\quad$ Azul de bromotimol (Synth, Diadema / SP, Brasil)

- Solução Karl Fischer isenta de piridina (Sigma-Aldrich, St. Louis, EUA)

- $\quad$ Metanol para análise (Merck, Darmstadt, Alemanha)

- $\quad$ Clorofórmio para análise (Synth, Diadema / SP, Brasil)

- Hexano para cromatografia (Mallincrkrodt, Phillipsburg, EUA)

- $\quad$ Reagente de esterificação $\mathrm{BF}_{3}$ (Merck, Darmstadt, Alemanha)

- $\quad$ n-Heptano (Tedia, HPLC/Spectro, Fairfield, EUA)

- $\quad$ Éter de petróleo (Synth, Diadema / SP, Brasil)

- $\quad \gamma$-orizanol padrão (Tsuno Rice Fine Chemicals Co., Wakayama, Japão, 99\%)

- $\quad \alpha$-tocoferol padrão (Sigma-Aldrich, St. Louis, EUA, 99\%)

- $\quad$ Cloreto férrico (J T Baker, Phillipsburg, EUA)

- $\quad$ Bipiridina (J T Baker, Phillipsburg, EUA)

- $\quad$ Tolueno (Ultimar, Mallinckrodt Chemicals, Hazelwood, EUA)

- $\quad$ EDTA padrão (Leco, St. Joseph, Michigan, EUA)

\subsubsection{Equipamentos}

- $\quad$ Banho termostático digital (Tecnal, modelo TE-184, Piracicaba / SP, Brazil)

- Balança analítica eletrônica (Adam, modelo PW 254, Milton Keynes, Inglaterra)

- Balança semi-analítica eletrônica (Adam, modelo PGW 1502i, Milton Keynes, Inglaterra) 
- $\quad$ Termômetro padrão com precisão $0,1{ }^{\circ} \mathrm{C}$ (Alla France, Chemillé, França)

- $\quad$ Estufa a vácuo (Tecnal, modelo TE-395, Piracicaba / SP, Brazil)

- $\quad$ Agitador magnético (IKA, modelo Lab disc IP65, Staufen, Alemanha)

- $\quad$ Titulador Karl Fischer (Metrohm, modelo 787 KF Titrino, Herisan, Suiça)

- $\quad$ Titulador automático (Metrohm, modelo Titrino 848, Herisan, Suiça)

- $\quad$ Bureta digital (Metrohm, modelo Dosimat 775, Herisan, Suiça)

- $\quad$ Células de equilíbrio de vidro pyrex (FGG, São Paulo / SP, Brasil)

- $\quad$ Extrator Soxhlet (Tecnal, modelo TE 188/6, Piracicaba / SP, Brazil)

- $\quad$ Estufa de convecção forçada (Nova Orgânica, modelo N 035/3, São Paulo / SP, Brasil)

- Cromatógrafo (Shimadzu, modelo GC 2010 AF com injetor automático modelo AOC 20i, Japão)

- $\quad$ Rotaevaporador (Tecnal, modelo TE 211, Piracicaba / SP, Brazil)

- $\quad$ Extrator em aço inoxidável (Tecnal, modelo TE-139-E4, Piracicaba / SP, Brazil)

- Viscosímetro (Anton Paar, modelo AMVn, Graz, Áustria)

- Densímetro (Anton Paar, modelo DMA 4500, Graz, Áustria)

- $\quad$ Espectrofotômetro (Shimadzu UV-Visível, UV 1650 PC, Japão)

- Determinador de proteína (Leco, modelo FP-528, St. Joseph, Michigan, EUA)

- $\quad$ Deionizador de água (MilliporeDirect-Q3-UV, Molheim, França)

- Centrífuga refrigerada (Thermo Electron Corp., modelo CR3i, França)

\subsubsection{Métodos}

\subsubsection{Caracterização das Matérias Primas}

A soja laminada (Cargill) e o farelo de arroz em pellets (gentilmente cedido pela Irgovel/Nutracea) foram caracterizados em termos do teor de lipídeos por extração em aparelho Soxhlet (método Am 2-93, AOCS, 1998) utilizando-se éter de petróleo como solvente. Um valor médio foi calculado com base em seis repetições para cada matériaprima estudada.

Os materiais também foram caracterizados em termos de umidade (AOCS, Ac 241, 1998), proteína total (AOCS, Ba 4e, 1998) e acidez livre por titulação com álcali (IUPAC, método a frio 2201, 1979). 
O farelo de arroz e a soja laminada foram, também, submetidos ao método de extração a frio proposto por Bligh e Dyer (1959). Os óleos obtidos neste procedimento, bem como o óleo vegetal utilizado no estudo do equilíbrio líquido-líquido (óleo de farelo de arroz degomado) foram caracterizados em termos de umidade pelo método AOCS (1998), acidez livre (método 2201 da IUPAC, 1979) e perfil de ácidos graxos através de cromatografia gasosa dos ésteres metílicos de ácidos graxos (métodos Ce 162(97) e Ce 2-66(97) da AOCS, 1998).

No caso dos estudos envolvendo o óleo de farelo de arroz, este foi também caracterizado em termos de: teor de $\gamma$-orizanol, determinado por espectrofotometria (Seetharamaiah e Prabhakar, 1986) e teor de tocóis (tocoferóis e tocotrienóis), através da metodologia colorimétrica sugerida por Emmerie e Engel (Parrish, 1980).

\subsubsection{Determinação dos Dados de Equilíbrio Sólido-líquido}

Os dados de equilíbrio sólido-líquido foram determinados de duas maneiras distintas:

- em células de equilíbrio construídas em vidro pyrex (Silva et al., 1997) (Figura 2.1), no caso dos dados obtidos até a temperatura de $60{ }^{\circ} \mathrm{C}$ (capítulo 3). As células são encamisadas podendo ser conectadas a um banho termostático e seladas, com o intuito de evitar perdas de massa por evaporação.

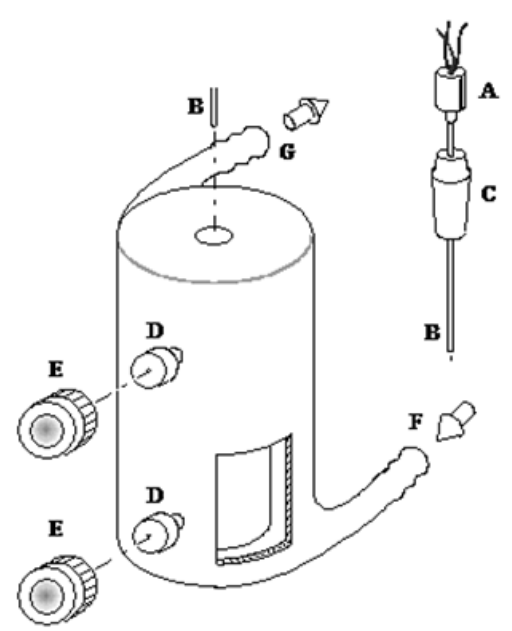

Figura 2.1 - Célula de equilíbrio em vidro pyrex utilizada para determinação dos dados de equilíbrio. A: Termômetro de resistência; B: Sonda; C: Vedação; D: Retirada de amostras; E: Septos; F: Entrada de fluido termostático; G: Saída de fluido termostático. 
Neste caso os sistemas sólido-líquido foram obtidos adicionando-se massas conhecidas da soja laminada ou do farelo de arroz (acondicionada/o em invólucro, resistente ao ataque pelo solvente orgânico e temperatura, e permeável ao solvente e ao extrato). A proporção mássica utilizada foi de 4,5: 1 (solvente: sólido) para a soja e 3: 1 (solvente: sólido) para o farelo de arroz. As soluções de etanol hidratado foram preparadas através de adição de água deionizada ao etanol absoluto.

Os dados de equilíbrio sólido-líquido foram obtidos de acordo com o procedimento mostrado na Figura 2.2. Quantidades pré-estipuladas de sólido e solvente (teor de água especificado pelo planejamento experimental) foram pesadas em béqueres e transferidas para a célula. As células foram submetidas à agitação magnética durante 24 horas.

A soja laminada ou o pellet de farelo de arroz foram acondicionados em invólucro o qual permitiu o contato da lâmina ou pellet com o solvente, preservando sua forma geométrica, não permitindo o esfarelamento da/o mesma/o. A temperatura da célula foi mantida constante durante todo o experimento, em valor pré-estipulado (especificado pelo planejamento experimental), através do banho termostático.

Após este tratamento, amostras da fase extrato foram extraídas com o auxílio de seringas e submetidas, imediatamente, às análises.

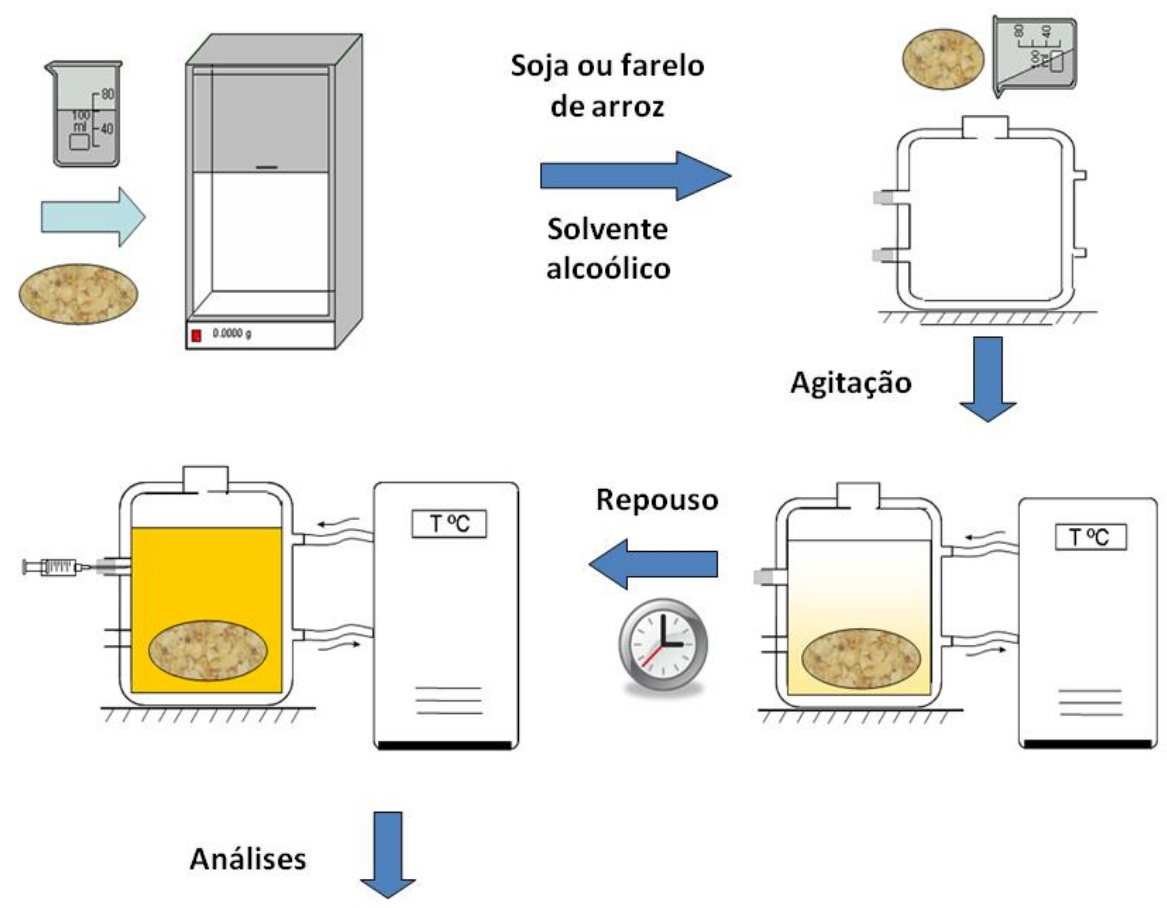

Figura 2.2 - Procedimento para obtenção de dados de equilíbrio sólido-líquido para sistemas de extração de óleo de soja e de farelo de arroz. 
- em extrator de aço inoxidável (Figuras 2.3 e 2.4), no caso das extrações realizadas a temperaturas superiores a $60{ }^{\circ} \mathrm{C}$ (capítulos 4 e 5). O tampo do equipamento é dotado de manômetro, válvula de escape (sistema de segurança) e rotor. O Extrator é vedado hermeticamente, evitando perdas de massa por evaporação. Os controles da temperatura e da rotação são feitos por controladores próprios do equipamento.

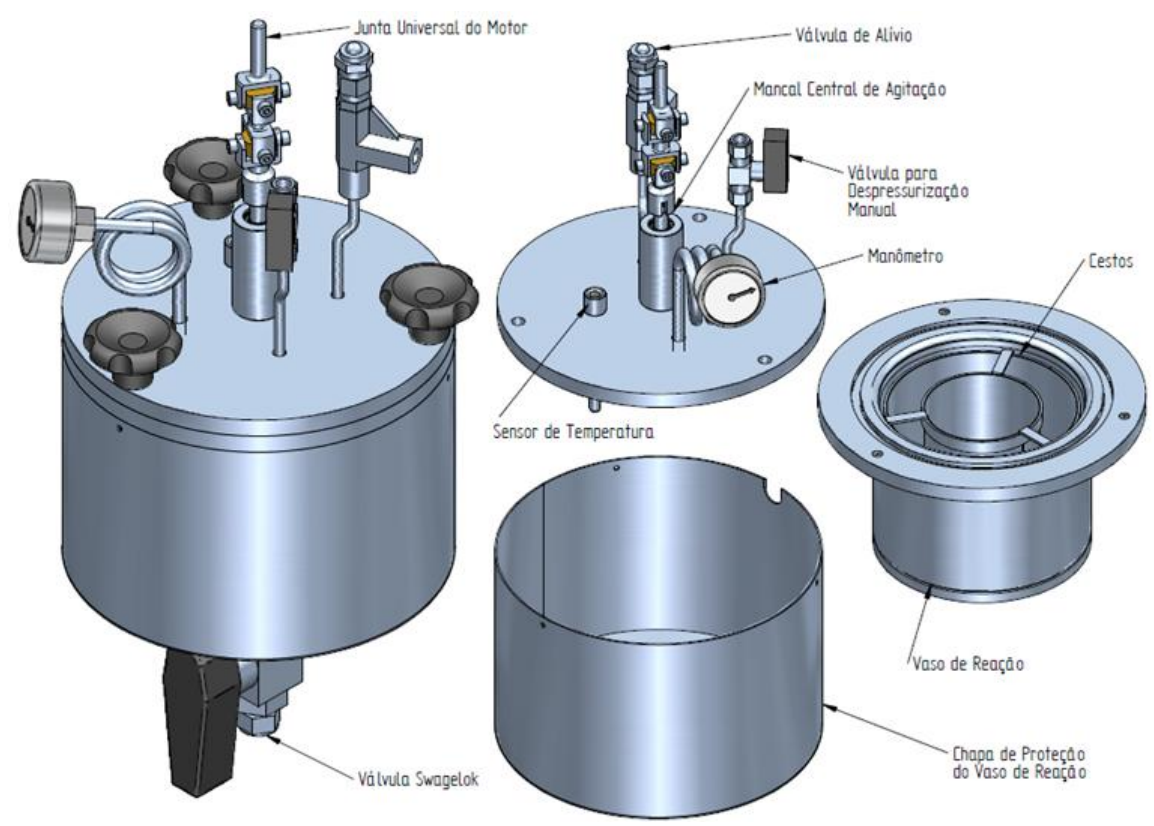

Figura 2.3 - Esquema do extrator de aço inox utilizado para determinação dos dados de equilíbrio. a) vista lateral; b) vista superior.

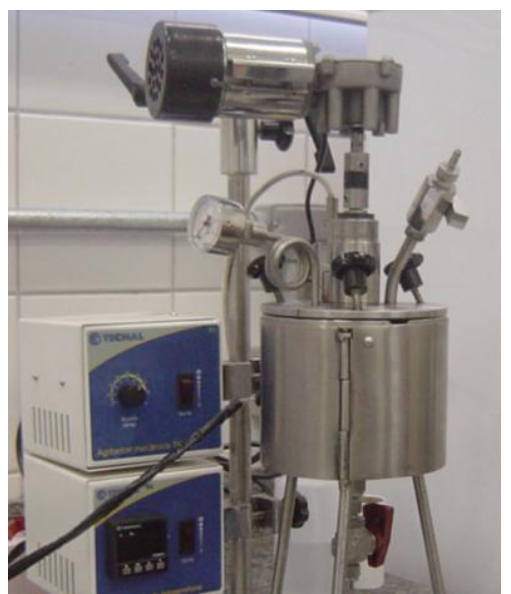

a)

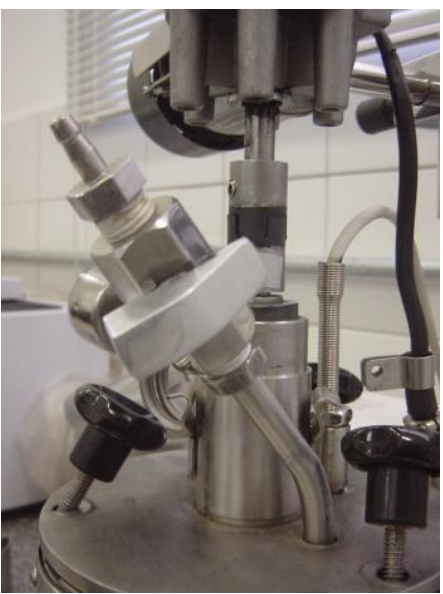

b)

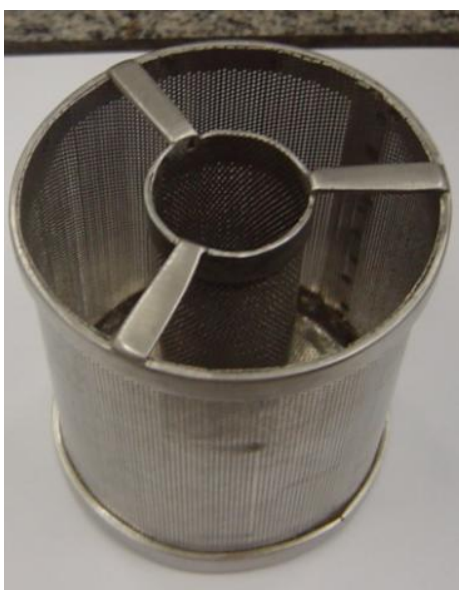

c)

Figura 2.4 - Extrator de aço inox existente no Laboratório de Engenharia de Separações. a) foto de vista lateral; b) detalhe da tampa; c) detalhe do cesto. 
Os sistemas sólido-líquido foram obtidos adicionando-se massas conhecidas de farelo de arroz em pellets ou soja laminada (acondicionado/a em suporte de aço inox, resistente ao ataque pelo solvente orgânico e temperatura, e permeável ao solvente e ao extrato). A proporção mássica entre solvente e sólido foi especificada pelo planejamento experimental. As soluções de etanol hidratado foram preparadas através de adição de água deionizada ao etanol absoluto.

As quantidades pré-estipuladas de sólido e solvente foram pesadas no suporte de aço inox e em béquer, respectivamente, por diferença, e transferidas para o extrator. $\mathrm{O}$ extrator foi submetido à agitação até a temperatura atingir o valor desejado (velocidade e temperatura especificadas pelo planejamento experimental) e mantido sob agitação constante por três horas.

Após este tratamento, amostras da fase extrato foram retiradas pela válvula localizada na parte inferior do vaso e colocadas em tubos com etanol absoluto, para a diluição da mesma. A diluição realizada com etanol absoluto (Merck) foi realizada para evitar a separação de fases com o abaixamento da temperatura. Deve-se enfatizar que o fator de diluição foi considerado nos cálculos das concentrações de todos os componentes. Amostras sem diluição foram separadas para a análise de composição em ácidos graxos livres por cromatografia, densidade e viscosidade. As amostras diluídas foram submetidas às análises, como descrito no item 2.1.2.5.

\subsubsection{Planejamento Fatorial - Extração sólido-líquido}

Três diferentes delineamentos experimentais foram utilizados para possibilitar a obtenção de modelos quadráticos para as diferentes respostas de interesse. A equação 2.1 apresenta a forma genérica da resposta como função dos efeitos lineares, quadráticos e de interação das variáveis independentes:

$$
y_{i}=\beta_{0} \pm \sum \beta_{i} X_{i} \pm \sum \beta_{i i} X_{i}^{2} \pm \sum \beta_{i j} X_{i} X_{j}
$$

Onde $y_{\mathrm{i}}$ é a resposta, $\mathrm{X}_{\mathrm{i}}$ e $\mathrm{X}_{\mathrm{j}}$ são as variáveis, $\beta_{0}$ é o termo constante, $\beta_{\mathrm{i}}$ é o coeficiente dos termos lineares, $\beta_{\mathrm{ii}}$ é o coeficiente do termos quadráticos, e $\beta_{\mathrm{ij}}$ é o coeficiente dos termos de interação. 
Foram realizados os seguintes tipos de delineamentos experimentais:

- O primeiro tipo, consistindo de 11 experimentos planejados para se obter um modelo quadrático composto de $2^{2}$ experimentos mais uma configuração estrela (ou pontos axiais) com três repetições no ponto central foi aplicado para as matérias-primas farelo de arroz e soja laminada. Os resultados referentes a estes planejamentos estão apresentados no Capítulo 3.

A Tabela 2.1 apresenta as variáveis codificadas utilizadas nestes estudos.

Tabela 2.1 - Variáveis codificadas para o primeiro planejamento.

\begin{tabular}{cccccc}
\hline & $\mathbf{- 1 , 4 1 4}$ & $\mathbf{- 1}$ & $\mathbf{0}$ & $\mathbf{+ 1}$ & $\mathbf{+ 1 , 4 1 4}$ \\
\hline $\mathrm{X}_{1}{ }^{\mathrm{a}}$ & 0,04 & 2,97 & 10,02 & 17,45 & 20,01 \\
$\mathrm{X}_{2}{ }^{\mathrm{b}}$ & 40 & 42,9 & 50 & 57,1 & 60 \\
\hline
\end{tabular}

Para a execução destes planejamentos os dados de equilíbrio sólido-líquido foram determinados de acordo com a metodologia descrita no item 2.1.2.2 (em células de equilíbrio construídas em vidro pyrex), fixando-se a razão mássica solvente: farelo em 4,5: 1, para a soja laminada e 3: 1, para o farelo de arroz.

As porcentagens experimentais de transferência de sólidos solúveis $\left(T_{\text {Sol }}\right)$, transferência de acidez livre $\left(T_{A G L}\right)$, transferência de orizanol $\left(T_{\text {Oriza }}\right)$ e transferência de água ( $\left.T_{\text {Água }}\right)$ foram calculadas através da equação 2.2 (adaptada de Rodrigues et al., 2006b).

$T_{i}(\%)=100 \frac{m^{F E} w_{i}^{F E}}{m^{\text {farelo }} w_{i}^{\text {farelo }}}$

Onde $m$ é a massa, $w$ é a fração mássica, $F E$ é a fase extrato e $i$ é sólido solúvel, ácido graxo livre, $\gamma$-orizanol ou água. Neste caso, a massa da fase extrato foi determinada por balanço de massa (procedimento descrito no item 2.1.2.6).

A resposta porcentagem de água na fase extrato (Água ${ }_{\mathrm{FE}}$ ) foi avaliada para cada dado experimental de acordo com a metodologia apresentada no item 2.1.2.5.4. A retenção, ou seja, quantidade de fase extrato retida na fase rafinado (RI, expressa como massa de solução aderida por massa de sólido inerte) foi avaliada através da quantificação da massa de fase rafinado, $F R$, para cada experimento realizado. 
- O segundo tipo, consistindo de 11 experimentos planejados para se obter um modelo quadrático composto de $2^{2}$ experimentos mais uma configuração estrela (ou pontos axiais) com quatro repetições no ponto central foi aplicado para a matéria-prima soja laminada. Os resultados referentes a este planejamento estão apresentados no Capítulo 4.

A Tabela 2.2 apresenta as variáveis codificadas utilizadas neste estudo.

Tabela 2.2 - Variáveis codificadas para o segundo planejamento.

\begin{tabular}{cccccc}
\hline & $\mathbf{- 1 , 4 1 4}$ & $\mathbf{- 1}$ & $\mathbf{0}$ & $\mathbf{+ 1}$ & $\mathbf{+ 1 , 4 1 4}$ \\
\hline $\mathrm{X}_{1}{ }^{\mathrm{a}}$ & 0,14 & 1,89 & 5,96 & 10,40 & 13,13 \\
$\mathrm{X}_{2}{ }^{\mathrm{b}}$ & 60 & 64,4 & 75 & 85,6 & 90 \\
\hline
\end{tabular}

a conteúdo de água no solvente (\% em massa). ${ }^{b}$ temperatura $\left({ }^{\circ} \mathrm{C}\right)$.

Para a execução deste planejamento os dados de equilíbrio sólido-líquido foram determinados de acordo com a metodologia descrita no item 2.1.2.2 (em células de equilíbrio construídas em aço inox), fixando-se a razão mássica solvente: farelo em 2,8: 1.

O rendimento da extração (Rend) foi calculado como massa de óleo (g) por massa de soja laminada $(100 \mathrm{~g})$. As porcentagens experimentais de transferência de água $\left(T_{\text {Água }}\right)$, transferência de sólidos solúveis $\left(T_{S o l}\right)$ e transferência de acidez livre $\left(T_{A G L}\right)$ foram calculadas através da equação 2.2. Em adição, foram também monitoradas as respostas: porcentagem de água na fase extrato (Água $\mathrm{FE}$ ), índice de retenção (RI) e propriedades físicas da fase extrato, densidade $\left(\rho_{\mathrm{FE}}\right)$ e viscosidade $\left(\eta_{\mathrm{FE}}\right)$.

- O terceiro tipo de planejamento experimental consistiu de 29 experimentos para se obter um modelo quadrático composto de 16 experimentos mais uma configuração estrela (ou pontos axiais) com cinco repetições no ponto central. Optou-se por realizar este planejamento fatorial completo com o intuito de investigar o efeito de quatro variáveis de processo nas seguintes respostas: porcentagens experimentais de transferência de sólidos solúveis $\left(T_{S o l}\right)$, transferência de acidez livre $\left(T_{A G L}\right)$, transferência de água $\left(T_{\hat{A} g u a}\right)$, porcentagem de água na fase extrato (Água $\mathrm{FE}$ ), índice de retenção (RI) e propriedades físicas da fase extrato, densidade $\left(\rho_{\mathrm{FE}}\right)$ e viscosidade $\left(\eta_{\mathrm{FE}}\right)$. Este terceiro planejamento experimental foi aplicado para a matériaprima farelo de arroz.

Além das respostas supramencionadas foram também avaliados o rendimento da extração (Rend) (massa de óleo (g) por massa de farelo de arroz (100 g)) e concentrações de 
compostos nutracêuticos, Oriza e Tocóis (massa de nutracêutico (mg) por massa de farelo de $\operatorname{arroz}(1000 \mathrm{~g}))$.

O planejamento fatorial completo para as 4 variáveis de processo analisadas (teor de água no solvente alcoólico, temperatura de extração, velocidade de rotação e razão solvente: farelo) consiste de cinco diferentes níveis, como apresentado na Tabela 2.3 (Capítulos 4 e 5).

Tabela 2.3 - Variáveis codificadas para o terceiro planejamento.

\begin{tabular}{cccccc}
\hline & $\mathbf{- 2}$ & $\mathbf{- 1}$ & $\mathbf{0}$ & $\mathbf{+ 1}$ & $\mathbf{+ 2}$ \\
\hline $\mathrm{X}_{1}{ }^{\mathrm{a}}$ & 0 & 6 & 12 & 18 & 24 \\
$\mathrm{X}_{2}{ }^{\mathrm{b}}$ & 60,0 & 67,5 & 75,0 & 82,5 & 90,0 \\
$\mathrm{X}_{3}{ }^{\mathrm{c}}$ & $2,5: 1$ & $3,0: 1$ & $3,5: 1$ & $4,0: 1$ & $4,5: 1$ \\
$\mathrm{X}_{4}{ }^{\mathrm{d}}$ & 100,0 & 137,5 & 175,0 & 212,5 & 250,0 \\
\hline${ }^{\mathrm{a}}$ conteúdo de água no solvente (\% em massa). ${ }^{\mathrm{b}}$ temperatura $\left({ }^{\circ} \mathrm{C}\right) .{ }^{\mathrm{c}}$ razão mássica solvente: farelo $(\mathrm{m} / \mathrm{m}) .{ }^{\mathrm{d}}$ \\
velocidade de agitação (rpm).
\end{tabular}

Os dados experimentais, provenientes dos três tipos de planejamentos, foram

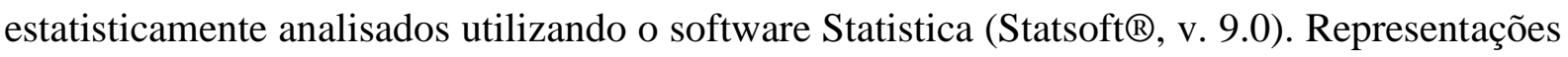
gráficas da equação 2.1 na forma de curvas de contorno (OriginLab®, v. 8.0) foram usadas para descrever os efeitos individuais e de interação das variáveis independentes testadas sobre as respostas (Box et al., 1978; Khuri e Cornell, 1987).

A capacidade descritiva e preditiva dos modelos estatísticos obtidos foi avaliada através do desvio relativo médio (DRM) (equação 2.3).

$\operatorname{DRM}(\%)=\left[\sum_{i=1}^{n}\left(\frac{\left|y_{i}^{e x}-y_{i}^{\text {calc }}\right|}{y_{i}^{e x}}\right)\right] \cdot \frac{100}{n}$

Onde $y_{i}$ representa a resposta, $n$ é o número de experimentos, ex e calc estão relacionados aos dados experimentais e calculados pelos modelos estatísticos, respectivamente.

\subsubsection{Determinação dos Dados de Equilíbrio líquido-líquido}

Os dados de equilíbrio líquido-líquido foram determinados para sistemas constituídos por óleo de farelo de arroz degomado e solvente, em tubos de centrífuga de polipropileno com tampa (Capítulo 6). 
Os ensaios foram realizados, segundo metodologia descrita por Rodrigues et al. (2003). Os tubos de centrífuga foram dispostos em béqueres, previamente tarados em balança analítica (precisão 0,0001g) e, cuidadosamente, receberam de acordo com a razão mássica óleo:solvente pré-estipulada, uma massa conhecida de óleo e solvente. Imediatamente o tubo foi vedado e agitado manualmente por aproximadamente 10 minutos.

Em seguida os tubos foram centrifugados por 15 minutos com rotação de $4500 \mathrm{~g}$ (temperatura controlada de $25^{\circ} \mathrm{C}$ ) em centrífuga de bancada com controle de temperatura.

Transcorridas as etapas de preparo, os sistemas foram mantidos por 6 horas em banho termostático, o qual permite o controle da temperatura em $\pm 0,1^{\circ} \mathrm{C}$.

Após o período de repouso, as fases oleosa e alcoólica foram retiradas, com o auxilio de seringas descartáveis, e então submetidas às análises.

Foram determinados os sistemas contendo óleo de farelo de arroz degomado / etanol / água $\left(0,62 ; 6,34 ; 18,87\right.$ ou $28,29 \%$ em massa), a 10,35 ou $60 \pm 0,1{ }^{\circ} \mathrm{C}$, em três diferentes razões mássicas óleo:solvente (2:1, 1:1, 1:2), totalizando 27 linhas de amarração.

\subsubsection{Análises da Fase Extrato (ESL), Fases Alcoólica e Oleosa (ELL) e matérias- primas}

\subsection{Determinação de Umidade na Soja e Farelo de arroz}

O teor de umidade nas matérias-primas foi determinado pelo método oficial (AOCS Ac 2-41, 1998) em estufa de convecção forçada, a $130{ }^{\circ} \mathrm{C}$ por 3 horas.

\subsection{Determinação da Concentração de Ácidos Graxos Livres}

A concentração dos ácidos graxos livres foi determinada por titulação com hidróxido de sódio $(\mathrm{NaOH})$ pelo método a frio 2201 da IUPAC (1979). Em recipiente fechado de 200 $\mathrm{mL}$, pesou-se de 2,0 a 2,5 g de amostra, da fase extrato, contida na seringa. Dissolveu-se a amostra em cerca de $65 \mathrm{~mL}$ de solvente (1:1 em volume de álcool etílico 95\% e éter etílico). Vale ressaltar que amostra do solvente utilizado na titulação foi titulada potenciometricamente com $\mathrm{NaOH}$, sendo o volume de titulante, gasto para neutralização, anotado. A solução (amostra + solvente) foi titulada com solução padronizada de $\mathrm{NaOH}$, potenciometricamente e sob agitação constante. A equação genérica para a reação é:

$$
\mathrm{CH}_{3}\left(\mathrm{CH}_{2}\right)_{\mathrm{n}} \mathrm{COOH}+\mathrm{NaOH} \rightarrow \mathrm{CH}_{3}\left(\mathrm{CH}_{2}\right)_{\mathrm{n}} \mathrm{COO}^{-} \mathrm{Na}^{+}+\mathrm{H}_{2} \mathrm{O}
$$

A concentração mássica de ácido graxo livre presente foi calculada segundo a equação: 


$$
A G L(\%)=\frac{\mathrm{V}_{\mathrm{NaOH}}^{*}(\mathrm{~mL}) \cdot \mathrm{N}_{\mathrm{NaOH}}(\mathrm{eq} / \mathrm{L}) \cdot \mathrm{MM}_{\mathrm{AGL}}(\mathrm{g} / \mathrm{gmol})}{10 \cdot \mathrm{M}_{\mathrm{amostra}}(\mathrm{g})}
$$

Onde: $\mathrm{V}_{\mathrm{NaOH}}^{*}(\mathrm{~mL})$ é o volume de $\mathrm{NaOH}$ gasto na titulação da amostra; $\mathrm{N}_{\mathrm{NaOH}}$ é a normalidade do titulante; $\mathrm{MM}_{\mathrm{AGL}}$ é a massa molar média dos ácidos graxos livres; $\mathrm{M}_{\mathrm{amostra}}$ é a massa de amostra. Todas as análises foram realizadas no mínimo em triplicata.

\subsection{Determinação da Concentração de Solvente (Etanol + Água)}

A concentração de solvente (etanol + água) foi determinada, em quintuplicata, por evaporação em estufa sob vácuo de $60 \mathrm{mmHg}$, a $60^{\circ} \mathrm{C}$, até peso constante. A porcentagem de solvente na fase extrato é dada pela seguinte expressão:

Solvente $(\%)=\frac{(\text { MassaInicial }- \text { Massa Final }) \cdot 100}{\text { MassaInicial }}$

\subsection{Determinação da Concentração de Água}

A concentração de água foi determinada pelo método de titulação Karl Fischer Ca 2e 55 da AOCS (1998). Amostras de extrato, de 0,01 a 0,1 g, foram tituladas com solução de Karl Fischer (KF) utilizando-se como solvente metanol/clorofórmio na proporção 4:1, em volume. O título do reagente KF utilizado foi determinado no início de cada titulação e a porcentagem mássica de água nas amostras, fornecida automaticamente pelo aparelho, é calculada através da seguinte expressão:

$$
\operatorname{Água}(\%)=\frac{\left(\mathrm{V}_{\mathrm{KF}} \cdot \text { Título }_{\mathrm{KF}}\right) \cdot 100}{\mathrm{M}_{\text {amostra }}}
$$

Todas as análises foram realizadas pelo menos em triplicata.

\subsection{Determinação da Composição em Ácidos Graxos Livres (Fatty acid methyl esters - FAME)}

Os óleos vegetais foram analisados por cromatografia gasosa de ésteres metílicos de ácidos graxos, de acordo com o método oficial 1-62 da AOCS (1998). Esta metodologia de análise foi aplicada aos óleos obtidos através de extração alcoólica, obtidos através do método proposto por Bligh e Dyer (1959) e, também, ao utilizado no estudo do equilíbrio líquidolíquido (óleo de farelo de arroz degomado). 
Foi utilizado um cromatógrafo gasoso Shimadzu 2010 AF (Japão), com injetor automático (Shimadzu, moldelo AOC 20i, Japão) e detector de ionização de chama nas seguintes condições experimentais: coluna capilar altamente polar bis-cianopropil 0,20 $\mu \mathrm{m}$, $100 \mathrm{~m}$ x 0,25 mm i.d. (SP - 2560, Supelco, Bellefonte, PA, USA), hélio como gás de arraste (velocidade linear de $20 \mathrm{~cm} / \mathrm{seg}$ ); temperatura do injetor de $240{ }^{\circ} \mathrm{C}$, temperatura da coluna de $140{ }^{\circ} \mathrm{C}$ (5 minutos), $140 / 240^{\circ} \mathrm{C}$ (taxa de $\left.4{ }^{\circ} \mathrm{C} / \mathrm{min}\right), 240{ }^{\circ} \mathrm{C}$ (15 minutos); temperatura do detector de $240{ }^{\circ} \mathrm{C}$ e volume de injeção de 1,0 $\mu \mathrm{L}$; split 100:1. Os ácidos graxos foram identificados por comparação com padrões externos adquiridos da Supelco (Bellefonte, PA, USA) e a sua quantificação foi realizada por normalização interna.

\subsection{Cálculo do Índice de Iodo via cromatografia gasosa}

O cálculo do Índice de Iodo (IV) foi realizado através do método oficial Cd 1c-85 (97) AOCS (1998).

\subsection{Determinação da Concentração de gama-orizanol}

A quantificação de $\gamma$-orizanol, no farelo de arroz em pellets e nos extratos alcoólicos, foi realizada por espectrofotometria como sugerido por Seetharamaiah e Prabhakar (1986) utilizando-se como solvente o n-heptano para espectrofotometria. Primeiramente realizou-se uma varredura da solução de gama-orizanol em heptano em toda a faixa do espectro UVVisível para se conhecer o comprimento de onda característico onde ocorre a máxima absorção. No caso específico do solvente n-heptano este comprimento de onda é 314,6 \pm 2 nm, como citado por Tsuno Co. (1995). Uma curva de calibração (do tipo $y=a \cdot x$, onde $y$ é a absorbância, $x$ é a concentração em $\mu \mathrm{g} / \mathrm{mL}$, e $a$ é o coeficiente angular da reta) foi construída com soluções de concentrações exatamente conhecidas de gama-orizanol em heptano no comprimento de onda de máxima absorção. A quantificação de gama-orizanol foi realizada pesando-se a amostra (aproximadamente $0,01 \mathrm{~g}$ ) em um balão volumétrico de $5 \mathrm{~mL}$, completando o volume com heptano. Posteriormente a solução foi transferida para cubetas de quartzo de $1 \mathrm{~cm}$ de caminho ótico, sendo a leitura da absorbância realizada a 314,6 $\pm 2 \mathrm{~nm}$ contra o branco.

A concentração de gama-orizanol expressa em \% é dada por:

$$
\text { gama }- \text { Orizanol }(\%)=\frac{A b s}{10000} \cdot \frac{5}{a \cdot m}
$$


Onde $m$ é a massa da amostra em gramas, $A b s$ é a absorbância da amostra e $a$ é o coeficiente angular da curva de calibração.

\subsection{Determinação da Concentração de Vitamina $E$ (tocóis = tocoferóis + tocotrienóis)}

A quantificação dos tocóis totais no farelo de arroz em pellets e nos extratos alcoólicos foi realizada por espectrofotometria, de acordo com metodologia desenvolvida por EmmerieEngel (Parrish, 1980), utilizando-se como solvente o tolueno para espectrofotometria.

O método consiste na pesagem de $200 \pm 10 \mathrm{mg}$ de amostra em um balão volumétrico de $10 \mathrm{~mL}$, adição de $5 \mathrm{~mL}$ de tolueno, $3,5 \mathrm{~mL}$ de solução de 2.2'-bipiridina $(0,07 \%$ massa/volume de etanol $95 \%)$ e $0,5 \mathrm{~mL}$ de $\mathrm{FeCl}_{3} \cdot 6 \mathrm{H}_{2} \mathrm{O}(0,2 \%$ massa/volume de etanol 95 $\%$ ), completando-se o volume com etanol aquoso $95 \%$. Depois de 1 min a solução é transferida para cubetas de $1 \mathrm{~cm}$ de caminho ótico, sendo a leitura da absorbância realizada a $520 \pm 2 \mathrm{~nm}$ contra o branco.

A concentração dos tocoferóis totais expressa em $\mathrm{mg} \cdot \mathrm{kg}$ é dada por:

Tocóis $\left(m g \cdot \mathrm{kg}^{-1}\right)=\frac{A b s}{10} \cdot \frac{\text { Vbalão }}{a \cdot m}$

onde $m$ é a massa da amostra em gramas, $A b s$ é a absorbância da amostra, $a$ é o coeficiente angular da curva de calibração e Vbalão é o volume do balão utilizado.

\subsection{Determinação do conteúdo de proteína nas matérias-primas}

A determinação do teor de proteína foi realizada através da quantificação do teor de nitrogênio presente através do método oficial AOCS Ba 4e (1998), utilizando-se o determinador de proteína LECO (modelo FP-528).

Procedeu-se a análise das amostras, no mínimo em quintuplicata, e obteve-se o teor de nitrogênio presente. A quantidade de proteína foi determinada multiplicando-se o teor de nitrogênio pelo fator 6,25 .

\subsection{Determinação da Concentração de Óleo}

Tendo sido determinadas as concentrações de ácidos graxos livres (item 2.1.2.5.2), de solvente (item 2.1.2.5.3), gama-orizanol (2.1.2.5.7) (no caso dos experimentos com farelo de arroz) e tocóis (2.1.2.5.8) (no caso dos experimentos com farelo de arroz) na fase extrato, determinou-se a concentração de óleo por diferença, de acordo com a equação 2.9. 


$$
\text { Óleo(\%)=100-(AGL(\%)+Orizanol(\%)+Solvente(\%)+Tocóis(\%)) }
$$

\subsection{Determinação das propriedades físicas dos compostos puros e extratos alcoólicos: Densidade e Viscosidade}

Os dados de densidade e viscosidade, necessários para o estudo do índice de retenção, foram determinados em equipamentos da Anton Paar, Densímetro Digital de bancada e Micro Viscosímetro Automático de queda de esfera, respectivamente. Para a medida dos valores de densidade dos extratos, as amostras foram injetadas diretamente no equipamento, que após estabilização da temperatura forneceu o resultado direto da densidade. Todas essas medidas foram realizadas em triplicata. Para a medida de viscosidade, as amostras foram adicionadas em um capilar de vidro calibrado, que por sua vez foi alocado no equipamento, fornecendo os valores da medida em quadruplicata, em 3 ângulos diferentes, totalizando 12 medidas por amostra.

As determinações das densidades e viscosidades dos compostos puros - água, etanol aboluto, etanol com 6\% de água, óleo degomado de farelo de arroz e óleo degomado de soja foram realizadas em temperaturas pré-estabelecidas. Já os dados das propriedades físicas de extratos foram medidos nas mesmas temperaturas em que foram realizados os processos de extração.

\subsubsection{Cálculos de Balanço de Massa para Estimativa da Composição da Fase Rafinado e Massa da Fase Extrato}

Para os experimentos sólido-líquido realizados, foram escritos $i$ balanços independentes por componente do sistema (Marcilla et al., 1995):

$M^{P M} w_{i}^{P M}=M^{F R} w_{i}^{F R}+M^{F E} w_{i}^{F E}$

onde $\mathrm{M}^{\mathrm{PM}}$ é a massa da mistura inicial, $\mathrm{M}^{\mathrm{FE}}$ e $\mathrm{M}^{\mathrm{FR}}$ são as massas das fases extrato e rafinado, respectivamente; $w_{i}{ }^{\mathrm{PM}}$ é a fração mássica do componente $i$ na mistura inicial e $w_{i}{ }^{\mathrm{FE}} \mathrm{e}$ $w_{i}{ }^{\mathrm{FR}}$ são as frações mássicas do componente $i$ nas fases extrato e rafinado, respectivamente.

Através destas $i$ equações, foi possível calcular os valores de $w_{i}^{\mathrm{FR}}$ e $\mathrm{M}^{\mathrm{FE}}$ com base nos valores experimentais de $w_{i}{ }^{\mathrm{FE}}$ e $\mathrm{M}^{\mathrm{FR}}$, pelo método dos mínimos quadrados, como descrito a seguir:

- Se M é a matriz formada pelos valores de $w_{i}{ }^{\mathrm{PM}}, \mathbf{B}$ é a matriz transformação (composta pelos valores de $\left.w_{i}^{\mathrm{FE}} \mathrm{e} w_{i}{ }^{\mathrm{FR}}\right)$ e $\mathbf{P}$ é a matriz formada pela massa de cada fase $\left(\mathrm{M}^{\mathrm{FR}} \mathrm{e}\right.$ $\mathrm{M}^{\mathrm{FE}}$ ), o sistema pode ser escrito como

$\mathbf{M}=\mathbf{B} . \mathbf{P}$ 
Cálculos matemáticos levam à seguinte expressão:

$$
\mathbf{P}=\left(\mathbf{B}^{T} \mathbf{B}\right)^{-1} \mathbf{B}^{T} \mathbf{M}
$$

Onde $\mathbf{B}^{T}$ é a matriz transposta de $\mathbf{B}$ e $\left(\mathbf{B}^{T} \mathbf{B}\right)^{-1}$ é a matriz inversa de $\left(\mathbf{B}^{T} \mathbf{B}\right)$. Desta forma, os valores de $\mathrm{M}^{\mathrm{FE}} \mathrm{e} w_{i}{ }^{\mathrm{FR}}$ que minimizam os erros do sistema podem ser calculados.

Vale ressaltar que $\mathrm{M}^{\mathrm{FR}}$ foi avaliado para cada sistema e, pelo balanço de massa global, $M^{P M}=M^{F R}+M^{F E}$

Os desvios $\delta$ entre a soma $\left(\mathrm{M}^{\mathrm{FE}}+\mathrm{M}^{\mathrm{FR}}\right)$ e $\mathrm{M}^{\mathrm{PM}}$, foram calculados de acordo com a expressão:

$$
\delta=\left(\frac{\left|\left(M^{F R}+M^{F E}\right)-M^{P M}\right|}{M^{P M}}\right) \cdot 100
$$

Os desvios $\left(\delta_{\mathrm{i}}\right)$ para cada componente do sistema podem ser calculados através da equação 2.15 ,

$$
\delta_{i}=\left(\frac{\left|\left(M^{F R} w_{i}^{F R}+M^{F E} w_{i}^{F E}\right)-M^{P M} w_{i}^{P M}\right|}{\left(M^{P M} w_{i}^{P M}\right)}\right) \cdot 100
$$

\subsubsection{Cálculos dos Parâmetros Termodinâmicos do Processo de Extração}

A análise termodinâmica do processo de extração foi realizada para a matéria-prima soja laminada. Nesta etapa do estudo foram consideradas as seguintes variáveis: teor de água no solvente $(0,2,6,10,12 \%$ de água em massa) e temperatura $(50,60,64,4,75,85,6,90$ e $100{ }^{\circ} \mathrm{C}$ ). Para cada condição pré-estabelecida de hidratação do solvente e temperatura foi determinado o coeficiente de distribuição dos sólidos solúveis definido pela equação 2.16.

$$
k_{\text {Sol }}=\frac{w_{S o l}^{F E}}{w_{\text {Sol }}^{F R}}
$$

Onde $w_{S o l}{ }^{\mathrm{FE}}$ e $w_{S o l}{ }^{\mathrm{FR}}$ são as frações mássicas do pseudo-componente sólidos solúveis nas fases extrato e rafinado, respectivamente, na condição de equilíbrio.

As variações de entalpia $\left(\Delta \mathrm{H}^{\circ}\right)$ e entropia $\left(\Delta \mathrm{S}^{\circ}\right)$ do processo de extração foram calculadas a partir da equação de van’t Hoff (equação 2.17) (Poling et al., 2001).

$\ln k=-\frac{\Delta H^{\circ}}{R T}+\frac{\Delta S^{\circ}}{R}$

Onde $\mathrm{R}$ é a constante universal dos gases $\left(8,3145 \mathrm{E}-3 \mathrm{~kJ} \cdot \mathrm{mol}^{-1} \cdot \mathrm{K}^{-1}\right)$, T é a temperatura absoluta (K), $k$ é o coeficiente de distribuição.

A variação da energia livre de Gibbs $\left(\Delta \mathrm{G}^{\mathrm{o}}\right)$ do processo de extração foi calculada a partir da expressão da energia livre de Gibbs (equação 2.18). 
$\Delta G^{\circ}=\Delta H^{\circ}-T \Delta S^{\circ}$

\subsubsection{Simulação do processo de extração sólido-líquido}

A simulação do processo de extração de óleo de farelo de arroz, utilizando etanol como solvente, foi realizada através da resolução simultânea do conjunto de equações de balanço de massa e equilíbrio.

Através da resolução destas equações foi possível calcular os fluxos mássicos e composições, em termos de sólidos inertes, solvente e óleo de farelo de arroz de todas as correntes que entram e saem de cada estágio do equipamento. Desta forma, dentro da unidade de extração, os cálculos foram realizados estágio a estágio, o que permite a determinação do número de estágios requerido para se atingir um determinado valor de lipídio residual na fase sólida.

A resolução do extrator sólido-líquido (ESL) foi tratada de forma matematicamente simplificada uma vez que o objetivo principal foi a determinação da composição da fase extrato que deixa o equipamento (corrente $\mathrm{E}_{1}$ na representação esquemática do ESL mostrada na Figura 2.5). Esta fase extrato foi submetida a um processo subsequente de resfriamento, o que permitiu a geração de duas fases líquidas, uma fase rica em óleo e outra rica em etanol, possibilitando uma pré-recuperação do solvente em um flash líquido-líquido.

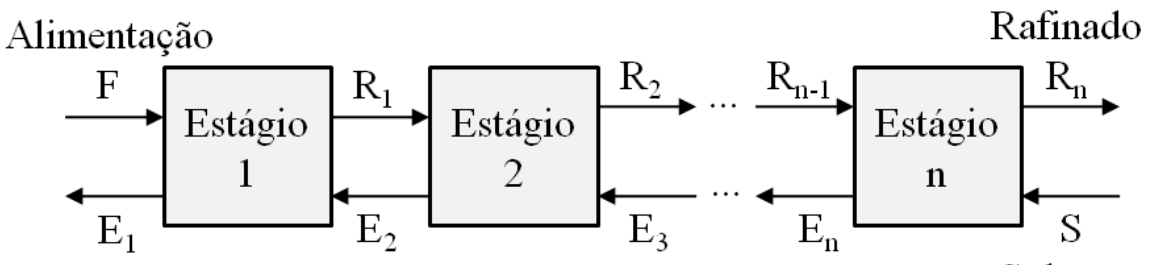

Extrato

Solvente

\section{Figura 2.5 - Representação esquemática do ESL com n estágios operando em contracorrente.}

Para a simulação do processo de extração sólido-líquido foram realizadas as seguintes considerações:

- utilização de extrator contínuo com modo de operação em contracorrente;

- as correntes de saída de cada estágio deixam o estágio em situação de equilíbrio.

As considerações abaixo citadas permitem satisfazer o balanço de energia:

- sistema isotérmico com temperaturas de operação de 50,0 ou $80,0^{\circ} \mathrm{C}$;

- sistema isobárico com pressão de operação de 101,3 kPa; 
- calor de mistura do soluto no solvente é negligenciável.

Em relação às correntes de entrada do extrator foram assumidas as seguintes condições:

- corrente de entrada chamada de "alimentação" (F), alimentada ao extrator no estágio $\mathrm{n}^{\circ} 1 \mathrm{com}$ vazão mássica de farelo de arroz de $1000 \mathrm{~kg} \cdot \mathrm{h}^{-1}$;

- farelo de arroz alimentado ao extrator apresenta, em fração mássica, a seguinte composição: 0,20 de óleo (designado como componente $c$ ), 0,71 de sólidos inertes (designado como $a$ ) e 0,09 de umidade;

- corrente de entrada contendo solvente puro (S), alimentada ao extrator no estágio $\mathrm{n}$.

- consideração de três diferentes valores de razão alimentação: solvente (F:S): 0,8; 1,0 e 1,2 ;

- avaliação de quatro tipos de solventes: hexano, etanol absoluto e etanol hidratado (com 6 ou $10 \%$ de água, em massa);

A recuperação do óleo de farelo de arroz foi fixada em $97 \%$.

No procedimento de simulação, o índice de retenção (RI) foi considerado constante ao longo dos estágios do equipamento de extração. Para as simulações considerando hexano como solvente, o valor de RI de 0,39 kg de líquido / $\mathrm{kg}$ de sólido foi utilizado de acordo com estudos prévios publicados por Rittner (1992) e Almeida et al. (2010).

Em relação ao etanol, os modelos estatísticos sugeridos nos capítulos 3 e 4 desta tese foram utilizados para estimar RI e o teor de água na fase extrato para as temperaturas de processo de 50,0 e $80,0^{\circ} \mathrm{C}$, respectivamente.

O balanço global de massa para os estágios 1 a n foi escrito de acordo com a equação 2.19:

$F+S=R_{n}+E_{1}$

Para cada estágio do extrator, os balanços de massa foram escritos como mostrado na Tabela 2.4. 
Tabela 2.4 - Balanços globais de massa para cada estágio do ESL.

\begin{tabular}{|c|c|c|c|}
\hline Estágio & \multicolumn{2}{|c|}{ Balanço global $^{\mathbf{a}}$} & Equação \\
\hline 1 & $F+E_{2}=R_{1}+E_{1}$ & $F-E_{1}=R_{1}-E_{2}=\Delta$ & $(2.20)$ \\
\hline 2 & $R_{1}+E_{3}=R_{2}+E_{2}$ & $R_{1}-E_{2}=R_{2}-E_{3}=\Delta$ & $(2.21)$ \\
\hline 3 & $R_{2}+E_{4}=R_{3}+E_{3}$ & $R_{2}-E_{3}=R_{3}-E_{4}=\Delta$ & $(2.22)$ \\
\hline $\mathrm{n}$ & $R_{n-1}+S=R_{n}+E_{n}$ & $R_{n-1}-E_{n}=R_{n}-S=\Delta$ & $(2.23)$ \\
\hline
\end{tabular}

${ }^{a} \mathrm{~F}, \mathrm{E}, \mathrm{R}, \mathrm{S}$ são vazões mássicas das correntes de alimentação, extrato, rafinado e solvente e $\Delta$ é a vazão mássica interestágio.

O balanço de massa para o soluto (óleo de farelo de arroz, componente $c$ ), generalizado e válido para qualquer estágio $\mathrm{i} \geq 1$, foi escrito como mostrado na equação 2.24.

$w_{c}^{E_{i+1}}=\frac{w_{c}^{R_{i}} \cdot R_{i}-w_{c}^{\Delta} \cdot \Delta}{E_{i+1}}$

Onde $w_{c}^{E_{i+1}}, w_{c}^{R_{i}}$ e $w_{c}^{\Delta}$ são as frações mássicas do soluto (óleo de farelo de arroz, $c$ ) nas correntes de extrato no estágio $i+1$, rafinado no estágio i e corrente $\Delta$, calculada de acordo com as equações 2.20 a 2.23 .

A relação de equilíbrio entre as correntes de saída de cada estágio foi considerada de acordo com a equação 2.25 .

$w_{c}^{R_{i}}=w_{c}^{E_{i}} \cdot\left(1-w_{a}^{R_{i}}\right)$

Onde $w_{c}^{R_{i}}$ e $w_{c}^{E_{i}}$ são as frações mássicas do soluto (óleo de farelo de arroz, $c$ ) nas correntes de rafinado e extrato no estágio $\mathrm{i} ; w_{a}^{R_{i}}$ é a fração mássica do sólido inerte (componente $a$ ) na corrente de rafinado no estágio i.

\subsubsection{Procedimento de avaliação da qualidade dos dados experimentais de equilíbrio} líquido-líquido

Com o objetivo de testar a validade dos resultados experimentais de equilíbrio líquidolíquido, o procedimento desenvolvido por Marcilla et al. (1995) foi adotado. De acordo com o procedimento foram escritos $i$ balanços independentes por componente do sistema, como mostrado a seguir:

$M^{P M} w_{i}^{P M}=M^{F O} w_{i}^{F O}+M^{F A} w_{i}^{F A}$ 
Onde $M^{P M}$ é a massa da mistura inicial, $M^{F O}$ e $M^{F A}$ são as massas das fases oleosa e alcoólica, respectivamente, $w_{i}^{P M}$ é a fração mássica do componente $i$ na mistura inicial e $w_{i}^{F A}$ e $w_{i}^{F O}$ são as frações mássicas do componente $i$ nas fases alcoólica e oleosa, respectivamente.

Através destas $i$ equações, foi possível calcular os valores de $M^{F O}$ e $M^{F A}$, com base nos valores experimentais de $w_{i}^{F A}$ e $w_{i}^{F O}$, pelo método dos mínimos quadrados: se $\mathbf{M}$ é a matriz formada pelos valores de $w_{i}^{P M}$, B é a matriz transformação (composta pelos valores de $w_{i}^{F A} \mathrm{e}$ $\left.w_{i}^{F O}\right)$ e $\mathbf{P}$ é a matriz formada pela massa de cada fase $\left(M^{F O}\right.$ e $\left.M^{F A}\right)$, o sistema pode ser escrito como,

$\mathbf{M}=\mathbf{B} . \mathbf{P}$

Cálculos matemáticos levam a seguinte expressão,

$\mathbf{P}=\left(\mathbf{B}^{T} \mathbf{B}\right)^{-1} \mathbf{B}^{T} \mathbf{M}$

Onde $\mathbf{B}^{T}$ é a matriz transposta de $\mathbf{B}$ e $\left(\mathbf{B}^{T} \mathbf{B}\right)^{-1}$ é a matriz inversa de $\left(\mathbf{B}^{T} \mathbf{B}\right)$. Desta forma, os valores de $M^{F O}$ e $M^{F A}$ (matriz $\mathbf{P}$ ) que minimizam os erros do sistema podem ser calculados. Os desvios $\delta$ entre a soma $\left(M^{O P}+M^{A P}\right)$ e $M^{O C}$, foram calculados de acordo com a expressão:

$\delta=\left(\frac{\left|\left(M^{F A}+M^{F O}\right)-M^{P M}\right|}{M^{P M}}\right) \cdot 100$

Os desvios $\left(\delta_{\mathrm{i}}\right)$ para cada componente do sistema podem ser calculados através da equação 2.30,

$\delta_{i}=\left(\frac{\left|\left(M^{F O} w_{i}^{F O}+M^{F A} w_{i}^{F A}\right)-M^{P M} w_{i}^{P M}\right|}{\left(M^{P M} w_{i}^{P M}\right)}\right) \cdot 100$

\subsubsection{Procedimento de modelagem dos dados experimentais de equilíbrio líquido- líquido}

Os dados experimentais de equilíbrio líquido-líquido, determinados em diferentes temperaturas para sistemas contendo óleo de farelo de arroz degomado e solvente foram utilizados para ajustar os parâmetros de interação do modelo UNIQUAC (Abrams e Prausnitz, 1975).

Os ajustes foram realizados considerando os sistemas compostos por óleo vegetal $\left(100 w_{1}\right)+$ ácidos graxos livres $\left(100 w_{2}\right)+$ etanol $\left(100 w_{3}\right)+$ água $\left(100 w_{4}\right)$, como um sistema pseudo-quaternário.

Os sistemas foram considerados compostos por um triacilglicerol simples com massa molar média do óleo vegetal, um ácido graxo representativo com massa molar média 
calculada de acordo com a composição em ácidos graxos do óleo vegetal, além de etanol e água.

Nos sistemas com óleo de farelo de arroz degomado, gama-orizanol e tocóis foram incorporados ao pseudo-componente óleo. Desta forma, parâmetros de interação entre os compostos nutracêuticos e demais componentes do sistema não foram avaliados nesta tese.

Tradicionalmente o modelo UNIQUAC é definido utilizando-se como unidade as frações molares. Neste trabalho o modelo termodinâmico foi utilizado em frações mássicas devido à utilização deste tipo de unidade ser mais conveniente no caso de sistemas onde os componentes apresentam diferenças significativas de massas molares. Este tipo de abordagem foi primeiramente utilizado por Oishi e Prausnitz (1978) para o cálculo dos coeficientes de atividade de solventes em soluções poliméricas utilizando os métodos UNIQUAC e UNIFAC. $\mathrm{Na}$ área de sistemas graxos este procedimento tem sido extensivamente utilizado com os modelos UNIQUAC e NRTL (Batista et al., 1999b; Cuevas et al., 2009; Rodrigues et al., 2005a, 2006a, 2007b).

O modelo UNIQUAC, utilizando fração mássica como unidade de concentração, adquire a forma apresentada abaixo no cálculo do coeficiente de atividade $\left(\gamma_{i}^{w}\right)$ :

$$
\begin{aligned}
& \gamma_{i}^{w}=\frac{\gamma_{i}}{M_{i}\left(\sum_{j=1}^{K} \frac{w_{j}}{M_{j}}\right)} \\
& \ln \gamma_{i}=\ln \gamma_{i}^{C}+\ln \gamma_{i}^{R} \\
& \ln \gamma_{i}^{C}=\frac{\ln \varphi_{i}^{\prime}}{\ln \left(w_{i} / \zeta \bar{M}_{i}\right)}+1-\frac{\zeta \bar{M}_{i} \varphi_{i}^{\prime}}{w_{i}}+\frac{z}{2} \bar{M}_{i} q_{i}^{\prime} \ln \frac{\theta_{i}^{\prime}}{\varphi_{i}^{\prime}}-\frac{z}{2} \bar{M}_{i} q_{i}^{\prime}\left(1-\frac{\varphi_{i}^{\prime}}{\theta_{i}^{\prime}}\right)
\end{aligned}
$$

Onde $\quad \zeta=\sum_{j=1}^{n} \frac{w_{j}}{\bar{M}_{j}}$

$$
\theta_{i}^{\prime}=\frac{q_{i}^{\prime} w_{i}}{\sum_{j} q_{j}^{\prime} w_{j}} ; \quad \varphi_{i}^{\prime}=\frac{r_{i}^{\prime} w_{i}}{\sum_{j} r_{j}^{\prime} w_{j}}
$$

e $\quad r_{i}^{\prime}=\frac{1}{\bar{M}_{i}} \sum_{j}^{C} x_{j} \sum_{k}^{G} v_{k}^{(i)} R_{k} ; \quad q_{i}^{\prime}=\frac{1}{\overline{M_{i}}} \sum_{j}^{C} x_{j} \sum_{k}^{G} v_{k}^{(i)} Q_{k}$

$\mathrm{Na}$ equação 2.36, $\mathrm{v}_{\mathrm{k}}{ }^{(\mathrm{i})}$ representa o número de grupos $\mathrm{k}$ na molécula do componente $\mathrm{i}$, Mi representa a massa molar do composto i, $G$ representa o número total de grupos, e $R_{k}$ e $Q_{k}$ representam os parâmetros de van der Waals obtidos de Magnussen et al. (1981). 
A contribuição residual para o cálculo do coeficiente de atividade é dada pela equação 2.37 .

$$
\ln \gamma_{i}^{R}=\bar{M}_{i} q_{i}^{\prime}\left[1-\ln \left(\sum_{j} \theta_{j}^{\prime} \tau_{j i}\right)-\sum_{j} \frac{\theta_{i}^{\prime} \tau_{i j}}{\sum_{k} \theta_{k}^{\prime} \tau_{k j}}\right]
$$

Sendo que os parâmetros $\tau_{i j}$ e $\tau_{j i}$ são definidos de acordo com as equações 2.38 e 2.39, considerando-se a dependência da temperatura.

$$
\begin{array}{lll}
\tau_{i j}=\exp \left(-\frac{a_{i j}}{T}\right) & \text { e } & \tau_{j i}=\exp \left(-\frac{a_{j i}}{T}\right) \\
a_{i j}=A_{0, i j}+A_{l, i j} T & \text { e } & a_{j i}=A_{0, j i}+A_{l, j i} T
\end{array}
$$

De acordo com a equação 2.39 tem-se quarto parâmetros ajustáveis para cada par de components $\left(A_{0, i j}, A_{0, j i}, A_{l, i j}\right.$ e $\left.A_{l, j i}\right)$. O procedimento para estimativa destes parâmetros baseouse na minimização da função objetivo de composições $(\mathrm{FO}(w))$, utilizando o Método Simplex Modificado, conforme sugerido por Stragevitch e d'Ávila (1997) (equação 2.40).

$$
F O(w)=\sum_{m=1}^{D} \sum_{n=1}^{N} \sum_{i=1}^{K-1}\left[\left(\frac{w_{i, n, m}^{F O, e x p}-w_{i, n, m}^{F O, \text { calc }}}{\sigma_{w_{i n n m}^{F O}}}\right)^{2}+\left(\frac{w_{i, n, m}^{F A, e x p}-w_{i, n, m}^{F A, \text { calc }}}{\sigma_{w_{i, n, m}^{F A}}}\right)^{2}\right]
$$

onde $D$ é o número total de bancos de dados (diagramas de equilíbrio), $N$ é o número total de linhas de amarração (tie-lines) em cada sistema, e $K$ é o número total de componentes no banco de dados $m$. $w$ é a fração mássica, os subscritos $i, n$ e $m$ são componente, linha de amarração e número do banco de dados, respectivamente, e os sobrescritos $F O$ e $F A$ representam as duas fases, oleosa e alcoólica, respectivamente; ex e calc se referem às concentrações experimentais e calculadas. $\sigma_{w_{i m m}^{F O}}$ e $\sigma_{w_{i m m}^{F A}}$ são os desvios padrões observados na composição das duas fases líquidas.

Os desvios entre as composições experimentais e calculadas em ambas as fases foram calculados de acordo com a equação 2.41 .

$$
\Delta w=100 \sqrt{\frac{\sum_{n=1}^{N} \sum_{i=1}^{K}\left[\left(w_{i, n}^{F O, e x p}-w_{i, n}^{F O, \text { calc }}\right)^{2}+\left(w_{i, n}^{F A, \text { exp }}-w_{i, n}^{F A, \text { calc }}\right)^{2}\right]}{2 N K}}
$$




\subsubsection{Estudo do processo de resfriamento dos extratos etanólicos}

Foi realizado o estudo do processo de resfriamento dos extratos etanólicos provenientes das extrações sólido-líquido estudadas via simulação, conforme procedimento descrito no item 2.1.2.8.

A corrente de extrato $E_{1}$ proveniente de cada processo de extração sólido-líquido (Figura 2.5) foi submetida a um processo de resfriamento o qual possibilitou a geração de duas fases líquidas, uma fase rica em óleo (OP, do inglês oil phase) e outra rica em solvente alcoólico (AP, alcoholic phase).

Os valores das composições das fases geradas foram estimados através de cálculos flash líquido-líquido, utilizando os parâmetros de interação do modelo termodinâmico UNIQUAC. Estes parâmetros foram ajustados aos dados experimentais de equilíbrio líquidolíquido conforme procedimento descrito no item 2.1.2.10.

Os componentes dos sistemas graxos utilizados para o ajuste dos parâmetros foram nomeados da seguinte forma: óleo de farelo de arroz degomado (1), ácidos graxos livres (2), etanol (3) e água (4).

No processo de resfriamento da corrente de extrato, o conteúdo de solvente na fase rica em óleo $\left(100 w_{3+4}^{O P}\right)$ e o conteúdo de óleo na fase rica em solvente $\left(100 w_{1}^{A P}\right)$ foram calculados considerando que a corrente de extrato $\left(\mathrm{E}_{1}\right)$ deixa o extrator sólido-líquido a 50,0 ou $80,0^{\circ} \mathrm{C}$ antes de ser resfriada para uma das três temperaturas estudadas $(35,0 ; 25,0$ ou 15,0 $\left.{ }^{\circ} \mathrm{C}\right)$. 
CATÍTULO 3

Análise do Processo de Extração de Óleos de Farelo de ARroz E SOJA COM ETANOL NA FAIXA DE Temperatura de 40 A $60{ }^{\circ} \mathrm{C}$. 


\subsection{Considerações Iniciais}

Como demonstrado no primeiro capítulo desta tese, o etanol pode ser utilizado como extratante de óleos vegetais em substituição ao hexano. Neste trabalho, o objetivo principal foi a avaliação do desempenho do etanol, com ou sem hidratação, na extração de óleos de soja e de farelo de arroz das matrizes sólidas, considerando, inicialmente, a utilização de temperaturas amenas de processo, 40 a $60^{\circ} \mathrm{C}$.

Nesta primeira fase do estudo foram realizados dois planejamentos fatoriais completos nos quais o teor de água no solvente etanol ( 0 a $20 \%$, em massa) e a temperatura $\left(40\right.$ a $\left.60{ }^{\circ} \mathrm{C}\right)$ foram considerados como variáveis independentes.

O processo de extração de óleo vegetal foi analisado tendo como objetivo a maximização da transferência de sólidos solúveis bem como a minimização da extração de ácidos graxos livres e retenção de extrato na fase rafinado. No caso do estudo envolvendo farelo de arroz foi possível, também, o monitoramento do comportamento do composto nutracêutico gama-orizanol.

Esta etapa do estudo possibilitou a publicação de dois artigos em periódicos internacionais (Rodrigues e Oliveira, International Journal of Food Science and Technology, 45, 813-820, 2010; e Rodrigues, Longo, Aracava e Garavazo, Chemical Engineering Transactions, 24, 811-816, 2011), além de três trabalhos completos em eventos nacionais (2) e internacional (1) e oito resumos em eventos.

\subsection{Resultados e Discussão}

\subsubsection{Caracterização das matérias-primas, farelo de arroz em pellets e soja laminada}

O farelo de arroz utilizado no estudo apresenta um formato cilíndrico com cerca de 5 de $\mathrm{mm}$ de diâmetro e $1 \mathrm{~cm}$ de comprimento. A soja laminada, gentilmente cedida pela Cargill, apresenta cerca de $0,5 \mathrm{~mm}$ de espessura e $1 \mathrm{~cm}^{2}$ de área. As densidades aparentes, obtidas como média de dez repetições, apresentaram os valor de $0,603 \pm 0,020 \mathrm{~g} \cdot \mathrm{cm}^{-3}$ para o farelo de arroz em pellets e $0,335 \pm 0,018 \mathrm{~g} \cdot \mathrm{cm}^{-3}$ para a soja laminada.

A Tabela 3.1 apresenta os valores médios obtidos para as diferentes caracterizações das matérias-primas. 
Tabela 3.1 - Caracterização das matérias-primas, farelo de arroz e soja laminada.

\begin{tabular}{lllllll}
\hline & \multicolumn{3}{c}{ Farelo de arroz } & \multicolumn{3}{c}{ Soja } \\
\hline & Média (\%) & $\begin{array}{l}\text { Desvio } \\
\text { Padrão }\end{array}$ & CV $(\%)^{\mathrm{b}}$ & Média (\%) & $\begin{array}{l}\text { Desvio } \\
\text { Padrão }\end{array}$ & $\mathrm{CV}(\%)^{\mathrm{b}}$ \\
\hline Umidade & 9,35 & 0,09 & 0,97 & 6,63 & 0,09 & 1,36 \\
Lipídeos totais $^{\mathrm{a}}$ & 20,03 & 0,06 & 0,30 & 18,44 & 0,18 & 3,11 \\
Acidez livre $^{\mathrm{a}}$ & 2,20 & 0,002 & 0,08 & 0,42 & 0,01 & 3,40 \\
gama-Orizanol $^{\mathrm{a}}$ & 0,47 & 0,002 & 0,41 & - & - & - \\
Proteína Bruta $^{\mathrm{a}}$ & 15,36 & 0,12 & 0,78 & 40,42 & 0,06 & 0,15 \\
\hline
\end{tabular}

${ }^{\mathrm{a}}$ Porcentagem em base seca. ${ }^{\mathrm{b}}$ Coeficiente de Variância.

Os resultados apresentados na Tabela 3.1 referentes à matéria-prima farelo de arroz estão de acordo com resultados prévios apresentados por Hu et al. (1996), Orthoefer (2005) e Lloyd et al. (2000). Para a soja, de maneira geral os resultados apresentados estão de acordo com Hammond et al. (2005). A Tabela 3.2 apresenta a composição em ácidos graxos dos óleos vegetais extraídos das matrizes sólidas seguindo a metodologia proposta por Bligh e Dyer (1959) (item 2.1.2.5.5 do Capítulo 2).

As massas molares médias da acidez livre, necessárias no cálculo da acidez livre no extrato, foram calculadas com base na composição do óleo em ácidos graxos livres (Tabela 3.2 ), apresentando o valor de $276,88 \mathrm{~g} \cdot \mathrm{mol}^{-1}$ para o óleo de farelo de arroz e $277,90 \mathrm{~g} \cdot \mathrm{mol}^{-1}$ para o óleo de soja. 
Tabela 3.2 - Composição em ácidos graxos dos óleos de farelo de arroz e de soja.

\begin{tabular}{llllllll}
\hline & & & \multicolumn{3}{c}{ Farelo de arroz } & \multicolumn{2}{c}{ Soja } \\
\hline Símbolo $^{\mathbf{a}}$ & Ácido Graxo & $\mathbf{C x : y} \mathbf{~}^{\mathbf{b}}$ & $\begin{array}{l}\mathbf{M M}^{\mathbf{c}} \\
\left(\mathbf{g} \cdot \mathbf{m o l}^{-\mathbf{1}} \mathbf{)}\right.\end{array}$ & Mássica (\%) & Molar (\%) & Mássica (\%) & Molar (\%) \\
\hline $\mathrm{M}$ & Mirístico & $\mathrm{C} 14: 0$ & 228,38 & 1,44 & 1,74 & 0,10 & 0,12 \\
$\mathrm{P}$ & Palmítico & $\mathrm{C} 16: 0$ & 256,43 & 17,73 & 19,14 & 11,36 & 12,33 \\
$\mathrm{~S}$ & Esteárico & $\mathrm{C} 18: 0$ & 284,49 & 2,30 & 2,23 & 4,15 & 4,06 \\
$\mathrm{O}$ & Oléico & $\mathrm{C} 18: 1$ & 282,47 & 35,20 & 34,51 & 22,83 & 22,49 \\
$\mathrm{Li}$ & Linoléico & $\mathrm{C} 18: 2$ & 280,45 & 37,98 & 37,50 & 52,82 & 52,42 \\
$\mathrm{Le}$ & Linolênico & $\mathrm{C} 18: 3$ & 278,44 & 2,62 & 2,61 & 7,41 & 7,41 \\
$\mathrm{~A}$ & Araquídico & $\mathrm{C} 20: 0$ & 312,54 & 0,57 & 0,51 & 0,35 & 0,31 \\
$\mathrm{Ga}$ & Gadoléico & $\mathrm{C} 20: 1$ & 310,52 & 0,34 & 0,30 & - & - \\
$\mathrm{Be}$ & Behênico & $\mathrm{C} 22: 0$ & 340,59 & 0,72 & 0,59 & 0,49 & 0,40 \\
$\mathrm{E}$ & Erúcico & $\mathrm{C} 22: 1$ & 338,58 & 0,35 & 0,28 & 0,17 & 0,14 \\
& Docosadienóico C22:2 & 336,56 & 0,33 & 0,27 & & \\
$\mathrm{Lg}$ & Lignocérico & $\mathrm{C} 24: 0$ & 368,65 & 0,42 & 0,32 & 0,20 & 0,15 \\
\hline
\end{tabular}

${ }^{a}$ Simbologia dos ácidos graxos. ${ }^{b} \mathrm{Cx}: \mathrm{y}, \mathrm{x}=$ número de carbonos e y=número de duplas ligações. ${ }^{\mathrm{c}} \mathrm{MM}=$ massa molar.

\subsubsection{Análise estatística do processo de extração}

No estudo da influência das variáveis de processo (temperatura e porcentagem mássica de água no solvente), os dados foram planejados e analisados estatisticamente, conforme mostrado no item 2.1.2.3 do Capítulo 2. A Tabela 3.3 apresenta a matriz do planejamento e as correspondentes respostas para a matéria-prima farelo de arroz. Os resultados pertinentes à soja laminada estão compilados na Tabela 3.4. 
Tabela 3.3 - Planejamento experimental $\left(2^{2}+4\right.$ pontos axiais +3 pontos centrais $)$ referente ao farelo de arroz.

\begin{tabular}{|c|c|c|c|c|c|c|c|c|c|}
\hline \multicolumn{2}{|c|}{ Variáveis Codificadas } & \multicolumn{2}{|c|}{ Variáveis Reais } & \multicolumn{6}{|c|}{ Respostas } \\
\hline $\mathrm{X}_{1}$ & $\mathrm{X}_{2}$ & $\mathrm{X}_{1}^{\mathrm{a}}$ & $\mathrm{X}_{2}{ }^{\mathrm{b}}$ & $\mathrm{T}_{\mathrm{Sol}}{ }^{\mathrm{c}}$ & $\mathrm{T}_{\mathrm{AGL}}{ }^{\mathrm{c}}$ & $\mathrm{T}_{\text {Oriza }}{ }^{\mathrm{c}}$ & $\mathrm{T}_{\text {Água }}{ }^{c}$ & Água $_{\mathrm{FE}}{ }^{\mathrm{d}}$ & $\mathrm{RI}^{\mathrm{e}}$ \\
\hline-1 & -1 & 2,97 & 42,4 & 64,44 & 23,53 & 23,40 & 16,57 & 3,89 & 0,82 \\
\hline+1 & -1 & 17,45 & 42,4 & 38,14 & 26,37 & 10,44 & 15,52 & 16,83 & 0,80 \\
\hline-1 & +1 & 2,97 & 57,1 & 65,19 & 31,72 & 27,44 & $-9,90$ & 4,23 & 1,04 \\
\hline+1 & +1 & 17,45 & 57,1 & 45,30 & 35,77 & 11,66 & $-8,58$ & 17,60 & 1,04 \\
\hline$-1,41$ & 0 & 0,04 & 50,0 & 73,64 & 23,34 & 44,14 & 78,88 & 2,67 & 0,77 \\
\hline$+1,41$ & 0 & 20,01 & 50,0 & 35,73 & 21,65 & 12,64 & $-15,04$ & 18,54 & 1,12 \\
\hline 0 & $-1,41$ & 10,02 & 40,0 & 34,16 & 24,51 & 14,74 & $-0,81$ & 9,56 & 0,92 \\
\hline 0 & $+1,41$ & 10,02 & 60,0 & 48,85 & 34,80 & 19,62 & $-7,24$ & 10,62 & 0,92 \\
\hline 0 & 0 & 10,02 & 50,0 & 47,90 & 31,58 & 15,15 & $-4,03$ & 11,19 & 0,92 \\
\hline 0 & 0 & 10,02 & 50,0 & 49,80 & 30,32 & 15,45 & $-1,65$ & 11,52 & 0,94 \\
\hline 0 & 0 & 10,02 & 50,0 & 51,13 & 32,67 & 15,84 & 0,45 & 11,85 & 0,93 \\
\hline
\end{tabular}

${ }^{\mathrm{a}}$ Conteúdo de água no solvente (\% em massa). ${ }^{\mathrm{b}}$ Temperatura $\left({ }^{\circ} \mathrm{C}\right) .{ }^{\mathrm{c}}$ Transferência $(\%)$ (calculada de acordo com equação 2.2 , capítulo 2$) .{ }^{\mathrm{d}}$ Água na fase extrato $(\%$ em massa). ${ }^{\text {e }}$ Retenção (massa de solução aderida por massa de sólido inerte). 
Tabela 3.4 - Planejamento experimental $\left(2^{2}+4\right.$ pontos axiais +3 pontos centrais $)$ referente à soja laminada.

\begin{tabular}{|c|c|c|c|c|c|c|c|}
\hline \multicolumn{2}{|c|}{ Variáveis Codificadas } & \multicolumn{2}{|c|}{ Variáveis Reais } & \multicolumn{4}{|c|}{ Respostas } \\
\hline $\mathrm{X}_{1}$ & $\mathrm{X}_{2}$ & $\mathrm{X}_{1}^{\mathrm{a}}$ & $\mathrm{X}_{2}{ }^{\mathrm{b}}$ & $\mathrm{T}_{\mathrm{Sol}}^{\mathrm{c}}$ & $\mathrm{T}_{\mathrm{AGL}}{ }^{\mathrm{c}}$ & Água $_{\mathrm{FE}}{ }^{\mathrm{d}}$ & $\mathrm{RI}^{\mathrm{e}}$ \\
\hline-1 & -1 & 2,97 & 42,4 & 61,40 & 33,39 & 4,65 & 1,40 \\
\hline+1 & -1 & 17,45 & 42,4 & 38,78 & 41,24 & 17,97 & 1,62 \\
\hline-1 & +1 & 2,97 & 57,1 & 97,18 & 43,16 & 4,46 & 1,28 \\
\hline+1 & +1 & 17,45 & 57,1 & 51,52 & 39,16 & 16,54 & 1,61 \\
\hline$-1,41$ & 0 & 0,04 & 50,0 & 90,09 & 46,05 & 1,55 & 1,27 \\
\hline$+1,41$ & 0 & 20,01 & 50,0 & 43,83 & 34,61 & 18,33 & 1,56 \\
\hline 0 & $-1,41$ & 10,02 & 40,0 & 36,88 & 37,89 & 11,23 & 1,62 \\
\hline 0 & $+1,41$ & 10,02 & 60,0 & 62,98 & 42,22 & 10,43 & 1,55 \\
\hline 0 & 0 & 10,02 & 50,0 & 49,02 & 33,80 & 9,94 & 1,52 \\
\hline 0 & 0 & 10,02 & 50,0 & 47,66 & 33,18 & 10,23 & 1,48 \\
\hline 0 & 0 & 10,02 & 50,0 & 50,38 & 31,26 & 10,23 & 1,45 \\
\hline
\end{tabular}

${ }^{\mathrm{a}}$ Conteúdo de água no solvente (\% em massa). ${ }^{\mathrm{b}}$ Temperatura $\left({ }^{\circ} \mathrm{C}\right) .{ }^{\mathrm{c}}$ Transferência $(\%)$ (calculada de acordo com equação 2.2 , capítulo 2$) .{ }^{\mathrm{d}}$ Água na fase extrato $(\%$ em massa). ${ }^{\text {e }}$ Retenção (massa de solução aderida por massa de sólido inerte). 
A análise estatística dos resultados experimentais permitiu a obtenção de modelos como função das variáveis estatisticamente significativas. Para o planejamento referente ao farelo de arroz, os modelos estatísticos representados pelas equações 3.1 a 3.6 estão dispostos na Tabela 3.5. Estes modelos representam a transferência de sólidos solúveis (\%), de AGL (\%), de gama-orizanol (\%), transferência de água (\%), teor de água no extrato (\%, em massa) e o índice de retenção (em $\mathrm{kg}$ de extrato / $\mathrm{kg}$ de fibras), respectivamente.

Tabela 3.5 - Modelos estatísticos para a matéria-prima farelo de arroz.

\begin{tabular}{lc}
\hline \multicolumn{1}{c}{ Modelo $^{\text {a }}$} & Equação \\
\hline$T_{\text {Sol }}(\%)=49,61-12,48 X_{1}+3,83 X_{1}^{2}+3,59 X_{2}-2,76 X_{2}^{2}$ \\
$T_{A G L}(\%)=31,41-3,66 X_{1}^{2}+4,02 X_{2}$ \\
$T_{\text {Oriza }}(\%)=15,21-9,16 X_{1}+5,40 X_{1}^{2}+1,52 X_{2}-0,70 X_{1} X_{2}$ \\
$T_{\text {Agua }}(\%)=-1,74-22,92 X_{1}+14,19 X_{1}^{2}-3,78 X_{2}^{2}$ \\
Água $_{F E}(\%)=11,16+6,09 X_{1}-0,53 X_{2}^{2}$ \\
$R I(k g / k g)=0,93+0,12 X_{1}$
\end{tabular}

${ }^{a} \mathrm{X}_{1}$ e $\mathrm{X}_{2}$ são variáveis codificadas.

A Tabela 3.6 apresenta os modelos estatísticos referentes à matéria-prima soja. Os modelos estatísticos representados pelas equações 3.7 a 3.10 são referentes às respostas transferência de sólidos solúveis (\%), de AGL (\%), teor de água no extrato (\%, em massa) e a retenção (em kg de extrato / kg de fibras), respectivamente.

Tabela 3.6 - Modelos estatísticos para a matéria-prima soja laminada.

\begin{tabular}{l}
\hline \multicolumn{1}{c}{ Modelo $^{\text {a }}$} \\
\hline$T_{S o l}(\%)=50,32-16,74 X_{1}+9,56 X_{1}^{2}+10,70 X_{2}-5,76 X_{2}^{2}$ \\
$T_{A G L}(\%)=32,75-1,54 X_{1}+3,56 X_{1}^{2}+1,73 X_{2}+3,43 X_{2}^{2}-2,96 X_{1} X_{2}$ \\
$A ́ g u a_{F E}(\%)=10,16+6,15 X_{1}-0,35 X_{2}+0,47 X_{2}^{2}$ \\
$R I(k g / k g)=1,49+0,12 X_{1}$ \\
${ }^{a} X_{1}$ e $X_{2}$ são variáveis codificadas.
\end{tabular}

As Tabelas 3.7 e 3.8 apresentam as análises de variância (ANOVA) para as respostas referentes à extração de óleo de farelo de arroz e de soja, respectivamente. 
Tabela 3.7 - Análise de variância (ANOVA) para farelo de arroz (análise a 90 \% de confiança).

\begin{tabular}{|c|c|c|c|c|c|c|}
\hline \multirow{2}{*}{ Fonte de variação } & $\mathrm{T}_{\text {Sol }}(\%)$ & $\mathrm{T}_{\mathrm{AGL}}(\%)$ & $\mathrm{T}_{\text {Oriza }}(\%)$ & $\mathrm{T}_{\text {Agua }}(\%)$ & Água & RI \\
\hline & $\mathrm{SQ}^{\mathrm{a}}$ & $\mathrm{SQ}^{\mathrm{a}}$ & $\mathrm{SQ}^{\mathrm{a}}$ & $\mathrm{SQ}^{\mathrm{a}}$ & $\mathrm{SQ}^{\mathrm{a}}$ & $\mathrm{SQ}^{\mathrm{a}}$ \\
\hline Regressão & 1474,0 & 212,0 & 872,1 & 5422,8 & 298,8 & 0,114 \\
\hline Resíduos & 96,6 & 39,1 & 73,8 & 1100,1 & 4,0 & 0,0013 \\
\hline Total & 1570,6 & 251,1 & 945,9 & 6833,1 & 302,8 & 0,115 \\
\hline $\mathrm{F}$ valor ( $\mathrm{F}$ tabelado) & $22,9(3,2)$ & $21,7(3,1)$ & $17,7(3,2)$ & $11,5(5,3)$ & $298,8(3,1)$ & $792,9(3,4)$ \\
\hline $\mathrm{CC}^{\mathrm{b}}$ & 0,97 & 0,92 & 0,96 & 0,92 & 0,99 & 0,99 \\
\hline $\operatorname{DRM}(\%)^{\mathrm{c}}$ & 5,60 & 5,10 & 7,80 & 183,1 & 5,53 & 5,72 \\
\hline
\end{tabular}

${ }^{\text {a }}$ Soma quadrática. ${ }^{b}$ Coeficiente de correlação. ${ }^{~}$ Desvio relativo médio (calculado de acordo com equação 2.3, capítulo 2).

Tabela 3.8 - Análise de variância (ANOVA) para soja laminada (análise a $95 \%$ de confiança).

\begin{tabular}{|c|c|c|c|c|}
\hline \multirow{2}{*}{ Fonte de variação } & $\mathrm{T}_{\text {Sol }}(\%)$ & $\mathrm{T}_{\mathrm{AGL}}(\%)$ & Água $\mathrm{FE}$ & RI \\
\hline & $\mathrm{SQ}^{\mathrm{a}}$ & $\mathrm{SQ}^{\mathrm{a}}$ & $\mathrm{SQ}^{\mathrm{a}}$ & $\mathrm{SQ}^{\mathrm{a}}$ \\
\hline Regressão & 3840,1 & 214,5 & 304,2 & 0,117 \\
\hline Total & 3899,6 & 239,7 & 305,6 & 0,161 \\
\hline $\mathrm{F}$ valor ( $\mathrm{F}$ tabelado) & $96,8(4,5)$ & $6,1(3,7)$ & $533,8(4,4)$ & $23,8(5,1)$ \\
\hline $\operatorname{DRM}(\%)^{\mathrm{c}}$ & 11,12 & 5,01 & 3,02 & 3,42 \\
\hline
\end{tabular}

${ }^{\mathrm{a}}$ Soma quadrática. ${ }^{\mathrm{b}}$ Coeficiente de correlação. ${ }^{\mathrm{c}}$ Desvio relativo médio (calculado de acordo com equação 2.3, capítulo 2). 
Como pode ser observado na Tabela 3.7, cinco das seis respostas analisadas para os sistemas com farelo de arroz apresentaram altos valores de coeficientes de correlação e valores aceitáveis de desvio relativo médio, para o nível de $90 \%$ de confiança.

As respostas transferência de sólidos solúveis, de ácidos graxos livres, de orizanol, água no extrato e retenção apresentaram valores calculados para o teste $\mathrm{F}$ muito maiores do que os correspondentes valores de $\mathrm{F}$ tabelados, o que mostra que as regressões para as respostas supramencionadas são estatisticamente significativas. Como regra prática, um modelo apresenta significância estatística quando o valor de F calculado é de três a cinco vezes maior que o valor de $\mathrm{F}$ tabelado. Isto torna as regressões além de significativas passíveis de serem utilizadas como preditivas (Box et al., 1978; Khuri e Cornell, 1987).

Em relação à resposta transferência de água, um baixo valor para o teste $\mathrm{F}$ foi obtido o que indica que o modelo apresentado na equação 3.4 (Tabela 3.6) deve ser utilizado somente para fins qualitativos.

No caso do sistema com soja, vide Tabela 3.8, pode-se observar que a resposta $\mathrm{T}_{\text {Sol }}$ apresentou um bom coeficiente de correlação, além disso, o teste $\mathrm{F}$ mostra que a regressão é estatisticamente significativa para o ajuste realizado uma vez que, o valor de F calculado apresentou-se 21,5 vezes maior que o valor de F tabelado, para o nível de 95\% de confiança. O mesmo tipo de resultado foi observado para as respostas Retenção e Água no extrato (\%). Pode-se observar na Tabela 3.8 que as análises de variância mostram que os modelos são válidos e preditivos.

Com relação ao resultado apresentado para a resposta $T_{\mathrm{AGL}}$, nota-se que o coeficiente de correlação obtido é razoável, no entanto, realizando-se o teste F observa-se que o valor de F calculado é apenas 1,6 vezes maior que o valor de $\mathrm{F}$ tabelado, fato que denota a regressão como não-preditiva.

Através dos modelos apresentados nas Equações 3.1 a 3.10 (Tabelas 3.6 e 3.7) foi possível gerar curvas de contorno que representam a influência de diferentes níveis de temperatura e conteúdos de água no solvente etanólico nas porcentagens de transferência de sólidos solúveis, AGL, gama-orizanol, água e nas respostas teor de água no extrato e retenção (Figuras 3.1 a 3.6, respectivamente). 


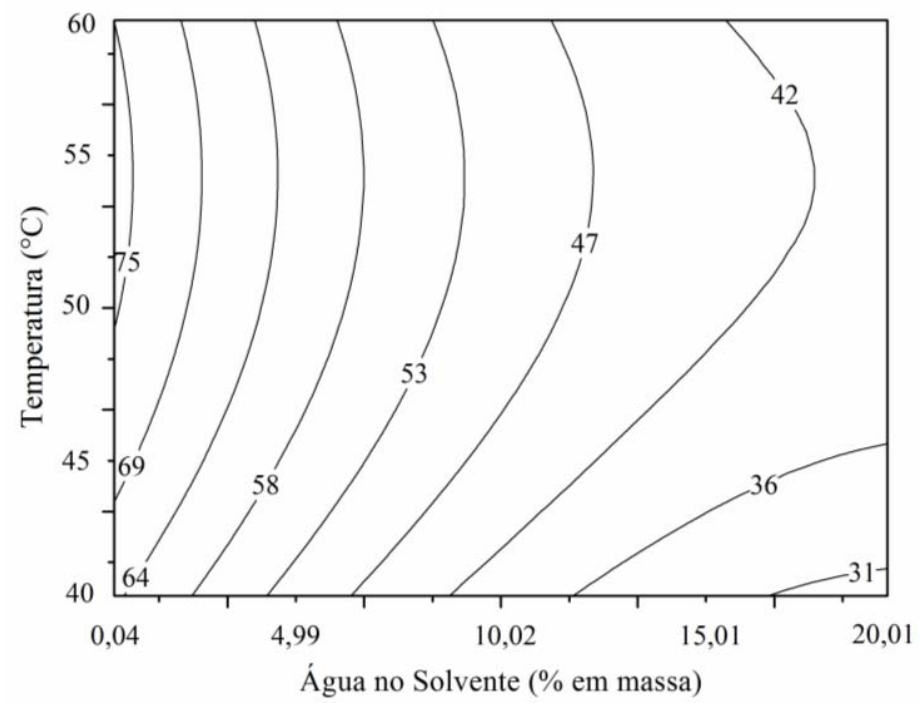

a)

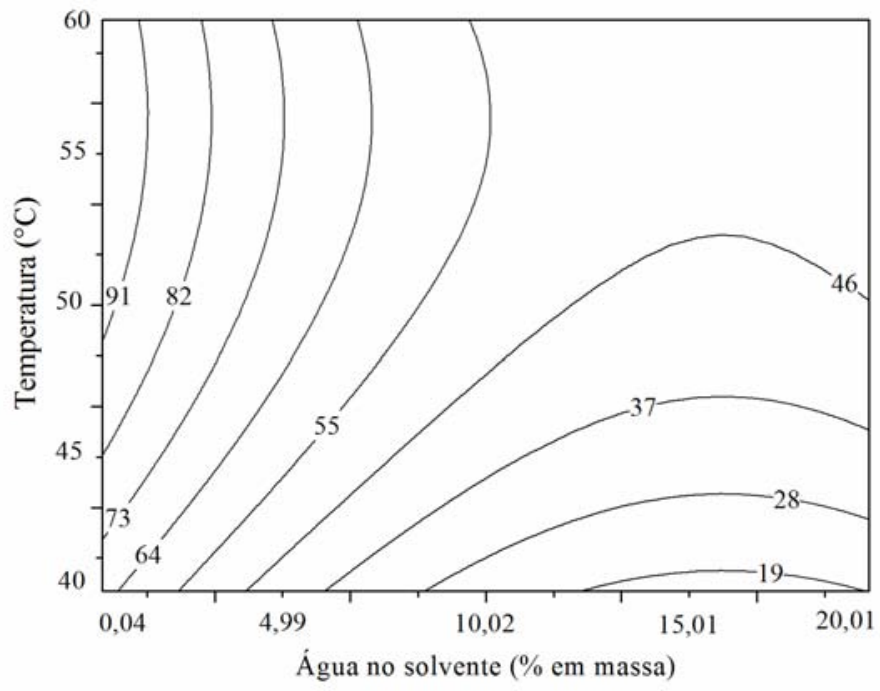

b)

Figura 3.1 - Curvas de contorno para Transferência de sólidos solúveis $\left(T_{\text {Sol }}\right)$ como função da temperatura $\left({ }^{\circ} \mathrm{C}\right)$ e teor de água no solvente (\% em massa) nos sistemas: a) farelo de arroz; b) soja.

Na Figura 3.1 pode ser observado que a transferência de sólidos solúveis $\left(\mathrm{T}_{\text {Sol }}\right)$, independentemente do tipo de matriz sólida (pellet de farelo de arroz (a) ou soja laminada (b)) é fortemente influenciada pelo teor de água no solvente etanólico. De fato, o aumento do teor de água no etanol suprime fortemente a extração de sólidos solúveis enquanto o aumento da temperatura somente favorece o aumento do nível de extração dos sólidos solúveis para menores teores de água no solvente.

A Figura 3.2 mostra que a extração de ácidos graxos livres (AGL), de maneira geral, aumenta com o incremento da temperatura. 


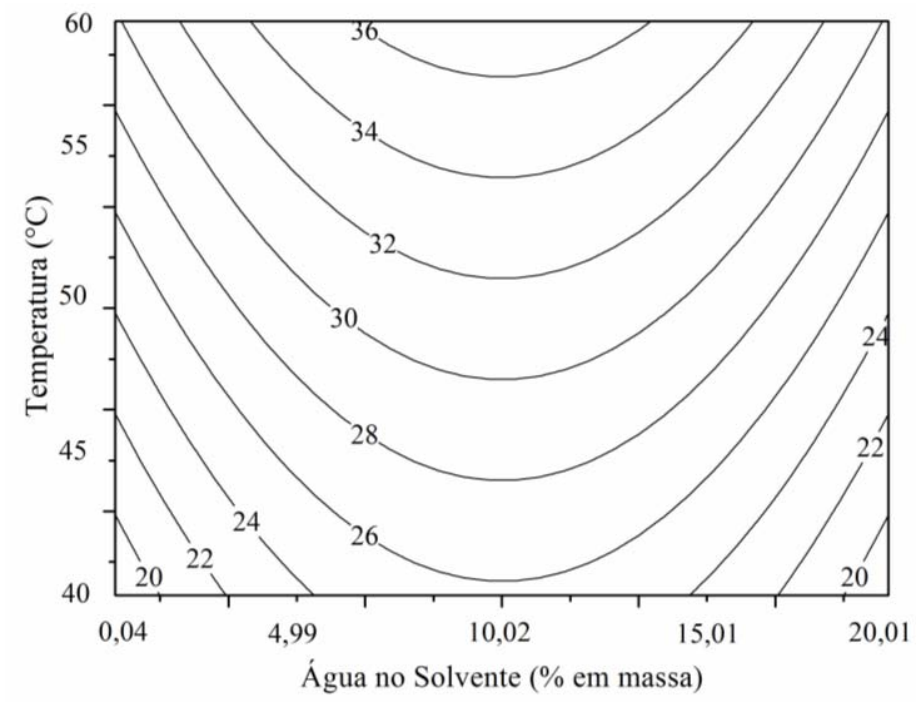

a)

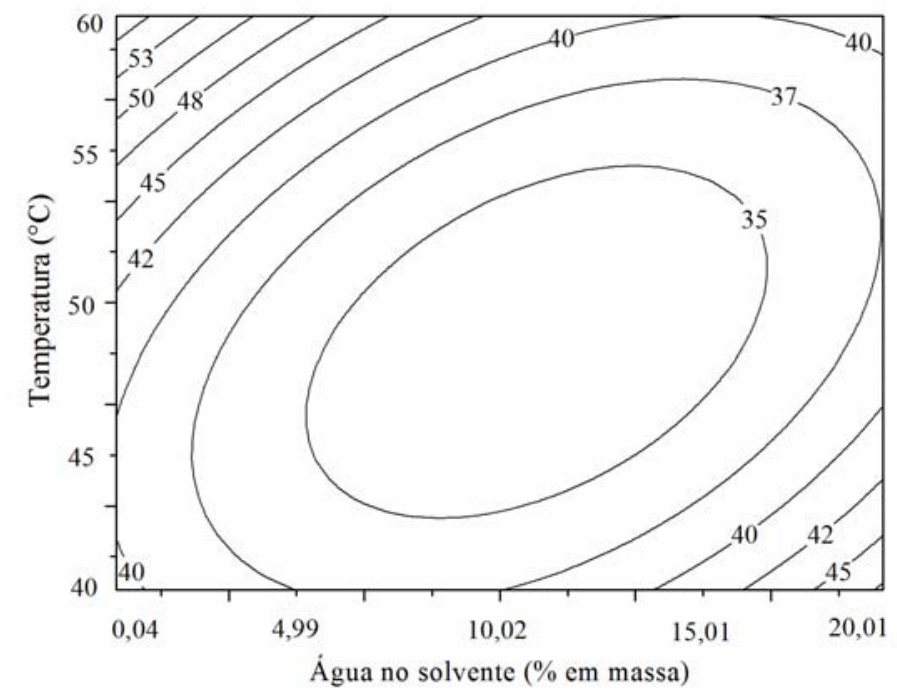

b)

Figura 3.2 - Curvas de contorno para Transferência de ácidos graxos livres $\left(T_{A G L}\right)$ como função da temperatura $\left({ }^{\circ} \mathrm{C}\right)$ e teor de água no solvente (\% em massa) nos sistemas: a) farelo de arroz; b) soja.

Na Figura 3.3 pode-se observar como a temperatura e o teor de água no solvente afetam a transferência de gama-orizanol. Nota-se que a presença da água no solvente desfavorece a extração do composto nutracêutico. Observa-se, também, que para altos teores de água no etanol a influência da temperatura é minimizada. 


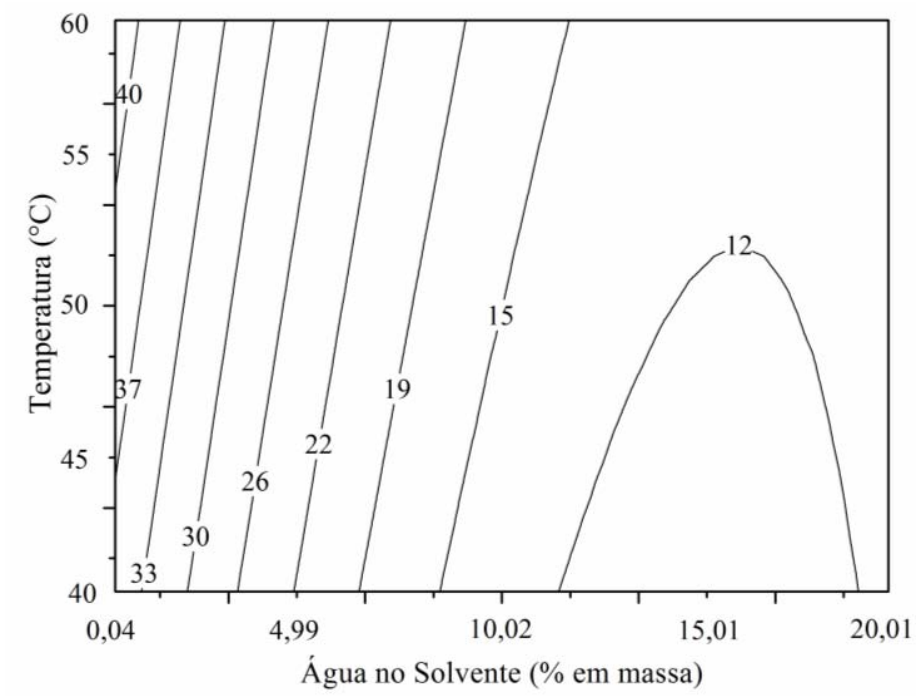

Figura 3.3 - Curvas de contorno para Transferência de gama-orizanol $\left(\boldsymbol{T}_{\text {Oriza }}\right)$ como função da temperatura $\left({ }^{\circ} \mathrm{C}\right)$ e teor de água no solvente (\% em massa).

Com base nos resultados mostrados nas Figuras 3.1 e 3.3, pode-se inferir que a força de interação intermolecular entre a água e etanol e, consequentemente, entre etanol e óleo ou etanol e orizanol, está intimamente associada à extensão do efeito da temperatura. Assim, pode-se propor que, para altos níveis de água no solvente, um aglomerado molecular é formado, proveniente de uma variedade de configurações de pontes de hidrogênio entre etanol e água, resultando em um efeito moderado da temperatura sobre o comportamento do sistema graxo. Este tipo de comportamento do sistema graxo, em relação ao teor de hidratação do solvente e temperatura foi previamente observado em trabalho publicado por Cuevas et al. (2009) e, também, está de acordo com publicações de Sanaiotti et al. (2008) e Silva et al. (2010a).

Chiyoda et al. (2010) propuseram que o óleo vegetal, por ser constituído por uma variedade de compostos não-polares, pode sofrer solvatação hidrofóbica em solventes com altos conteúdos de água. Em sistemas contendo solventes hidratados, a hidratação hidrofóbica do óleo pode estar associada com o insignificante efeito da temperatura sobre a solubilidade do óleo (Okamoto et al., 1998; Tominaga et al., 1990).

A Figura 3.4 apresenta a analise estatística referente à resposta transferência de água no sistema com farelo de arroz. Na Figura 3.5 pode-se observar a dependência do conteúdo de água na fase extrato como função das variáveis independentes, para ambos os sistemas estudados, farelo de arroz e soja. 


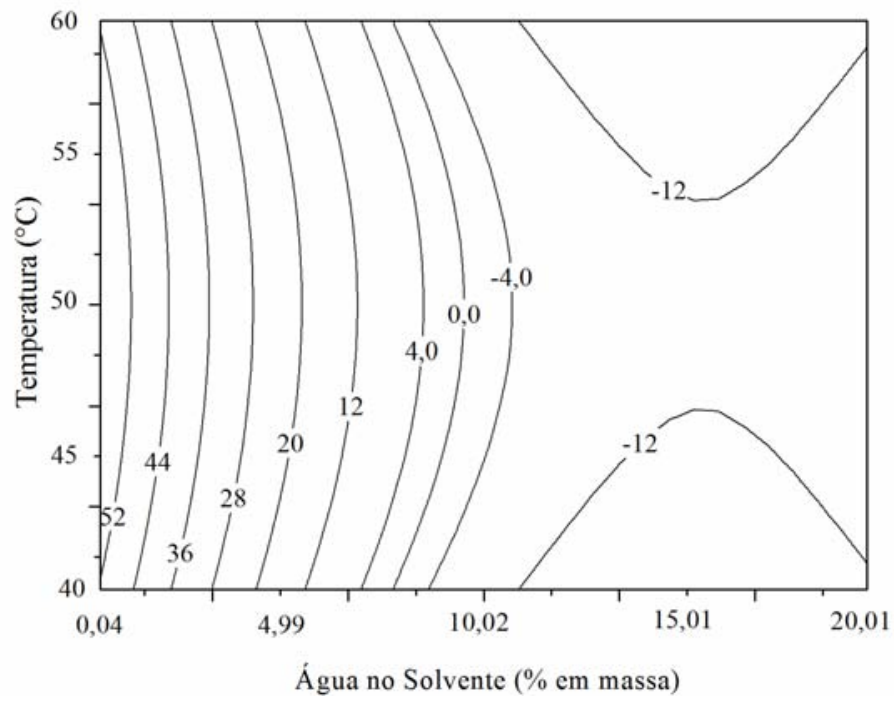

Figura 3.4 - Curvas de contorno para Transferência de água $\left(T_{\text {Água }}\right)$ como função da temperatura $\left({ }^{\circ} \mathrm{C}\right)$ e teor de água no solvente (\% em massa) no sistema com farelo de arroz. 


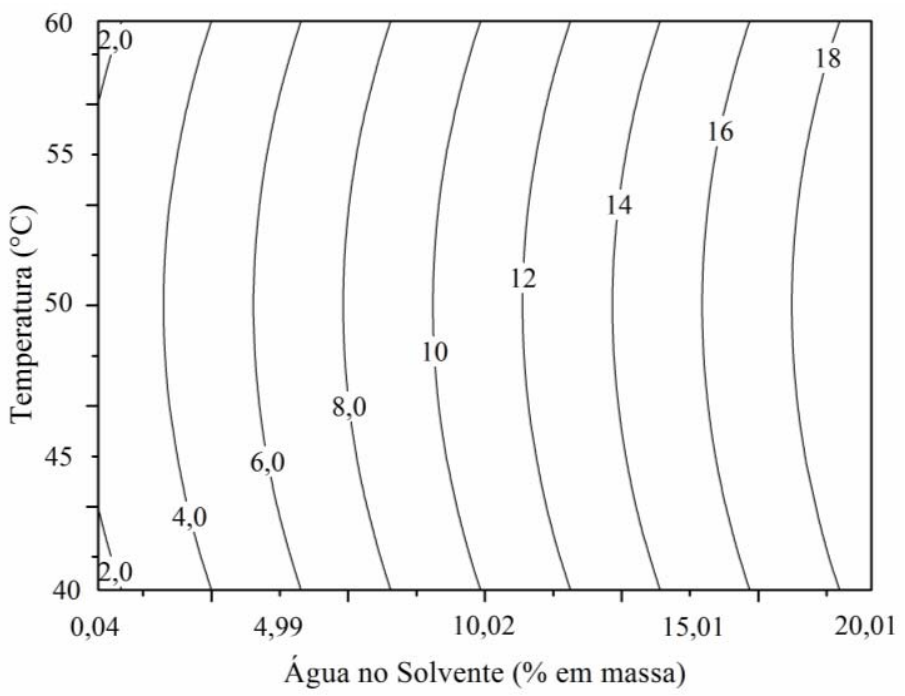

a)

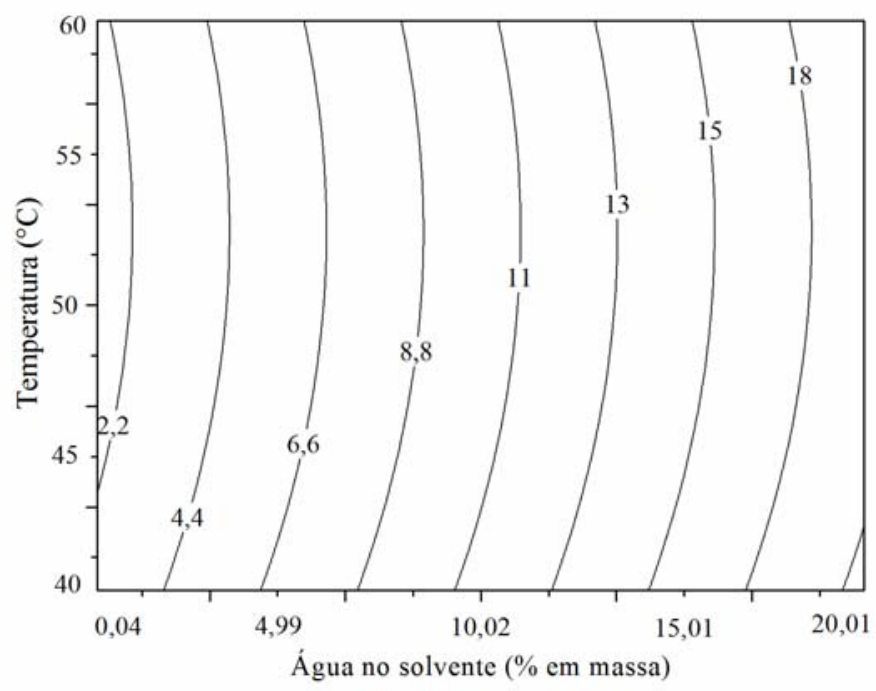

b)

Figura 3.5 - Curvas de contorno para conteúdo de água na fase extrato (Água ${ }_{F E}$ ) como função da temperatura $\left({ }^{\circ} \mathrm{C}\right)$ e teor de água no solvente (\% em massa) nos sistemas: a) farelo de arroz; b) soja.

Nota-se que o processo de transferência de água, do farelo para o extrato, praticamente independe da temperatura (vide Figuras 3.4 e 3.5). De fato, o que pode ser observado é que existe um equilíbrio entre a umidade contida no sólido e o teor de água no solvente utilizado. Nota-se que o etanol absoluto, quando é utilizado para a extração do óleo, extrai maior quantidade de água contida na estrutura sólida do que um solvente etanólico com alto teor de água.

Este fenômeno de hidratação do solvente etanólico foi previamente reportado por Abraham et al. (1993) e Franco et al. (2007), para as matérias-primas algodão e Rosa rubiginosa, respectivamente. Vale ressaltar que neste trabalho as matérias-primas farelo de 
arroz em pellets e soja laminada foram utilizadas sem secagem prévia o que permitiu a visualização do fenômeno de hidratação do solvente.

Na Figura 3.6 pode-se observar que o índice de retenção (RI), teor de solução aderida às fibras, é somente dependente do conteúdo de água no solvente. Nota-se, de maneira geral, que a retenção aumenta com o aumento do teor de água no solvente.

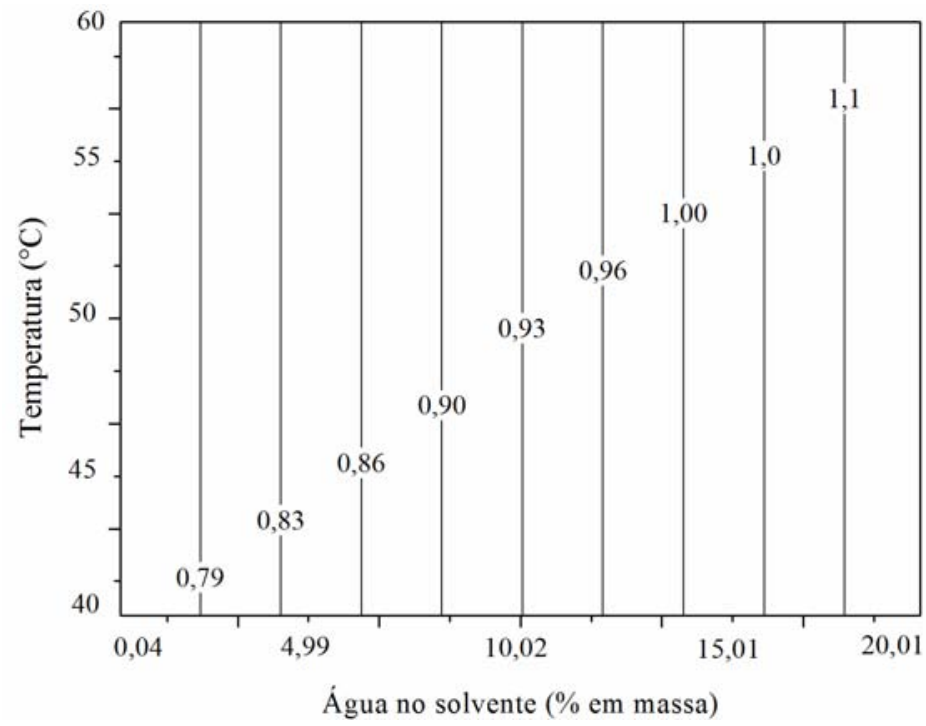

a)

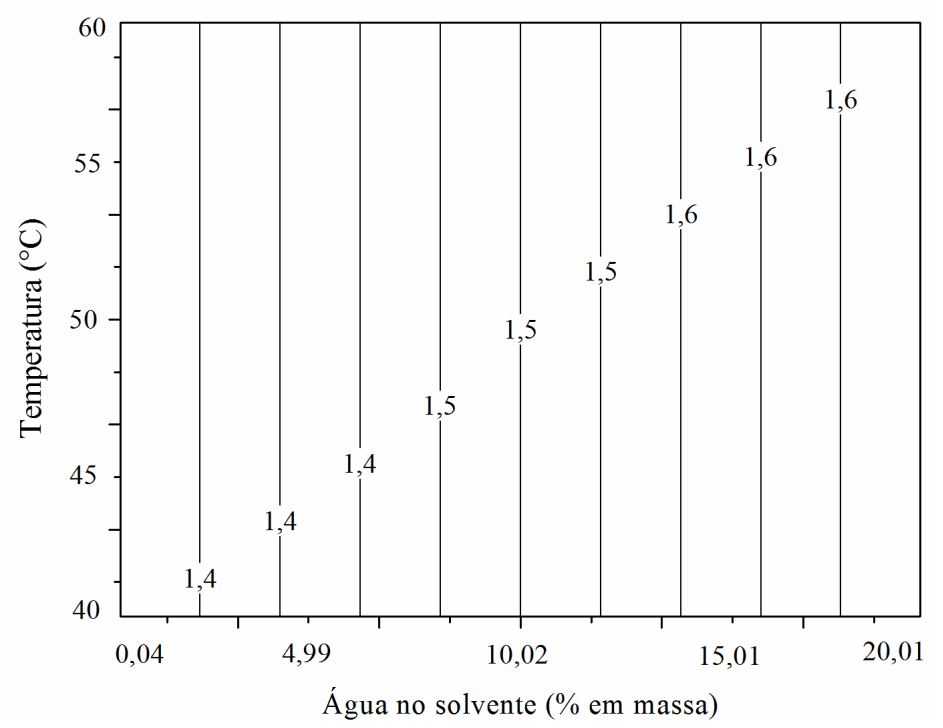

b)

Figura 3.6 - Curvas de contorno para índice de retenção (RI) como função da temperatura $\left({ }^{\circ} \mathrm{C}\right)$ e teor de água no solvente (\% em massa) nos sistemas: a) farelo de arroz; b) soja.

Na Figura 3.6 é possível observar, ainda, que os valores de retenção para os sistemas com soja laminada são sempre superiores aos valores determinados para os sistemas com 
farelo de arroz em pellets. Estes resultados podem estar relacionados aos diferentes prétratamentos sofridos industrialmente pelas matérias-primas utilizadas neste trabalho. De acordo com Rittner (1992), a retenção em sistemas contendo soja laminada e hexano é cerca de 1,4 vezes maior se comparada a sistemas contendo soja em pellets e o mesmo solvente fóssil.

Infelizmente, dados para o índice de retenção em sistemas contendo farelo de arroz e etanol não estão disponíveis na literatura. No entanto, Rittner (1992) e Wisniak et al. (1987) publicaram dados de hold-up de líquido para sistemas de extração de óleo de soja e de jojoba, respectivamente. Rittner (1992) e Wisniak et al. (1987) observaram que os valores de hold-up de líquido para o etanol absoluto e isopropanol, respectivamente, são sempre superiores aos valores obtidos para o solvente hexano.

Desta forma, pode-se inferir que há uma forte atração entre o álcool (solvente polar) e a superfície do material sólido submetido ao processo de extração (Rittner, 1992). Uma vez que a polaridade do solvente aumenta com o aumento do nível de hidratação, pode-se inferir que as forças atrativas entre o solvente e o sólido aumentam, elevando o nível de solução aderida às fibras.

De fato, é importante enfatizar que o índice de retenção, ou hold-up de líquido, é uma variável de projeto que impacta de forma decisiva no número de estágios necessários para realizar a extração (volume do extrator) e, também, na etapa de recuperação do solvente aderido ao farelo (etapa de dessolventização do farelo).

\subsubsection{Otimização do processo de extração de óleo de farelo de arroz}

Com o objetivo de verificar qual a região de operação mais indicada para se obter um máximo de extração de sólidos solúveis e gama-orizanol e valores mínimos de extração de acidez livre e retenção, uma função objetivo otimizada (FO) pode ser proposta como uma divisão entre as respostas que devem ser maximizadas pelas respostas que devem ser minimizadas (equação 3.11).

$$
F O=\frac{\left(T_{\text {Sol }} \cdot T_{\text {Oriza }}\right)}{\left(T_{A G L} \cdot R I\right)}
$$

A Figura 3.7 apresenta a FO como função do nível de hidratação no solvente e temperatura de extração.

Pode-se observar na Figura 3.7 que para maximizar a extração dos sólidos solúveis totais bem como de gama-orizanol, simultaneamente minimizando a extração da acidez livre e 
a retenção, é necessário utilizar solventes com baixos teores de água, independentemente da temperatura do processo.

Analisando-se as Figuras 3.4, 3.5 e 3.7, simultaneamente, pode-se inferior que o nível ótimo de hidratação do solvente apresenta-se na faixa de 5 a $10 \%$, em massa. Para esta faixa de composição a função objetivo apresenta valores, em unidades arbitrárias, de 30 a $75 \%$. Deve-se ressaltar que a escolha desta faixa de operação leva em consideração, também, a etapa de recuperação do solvente etanólico contido na fase extrato. Teores de água no solvente de 5 a $10 \%$, em massa, viabilizam a recuperação do etanol presente na fase extrato por destilação simples.

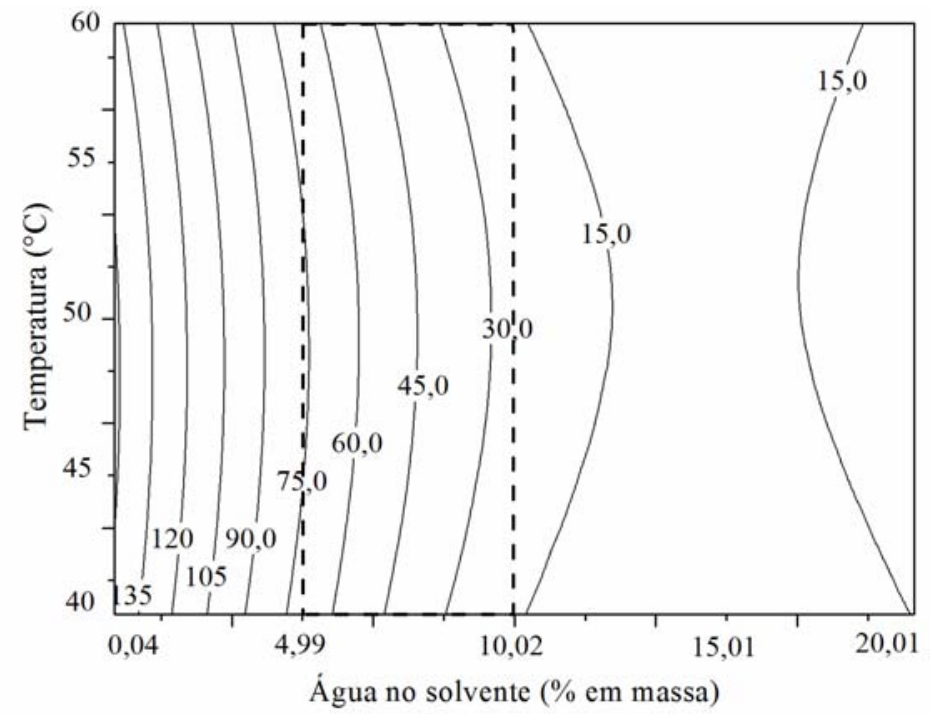

Figura 3.7 - Curvas de contorno para a função otimizada (FO) como função da temperatura $\left({ }^{\circ} \mathrm{C}\right)$ e teor de água no solvente (\% em massa).

\subsection{Conclusões}

Nesta primeira etapa do estudo foram apresentados resultados experimentais referentes a extração de óleo de farelo de arroz e de soja, em um estágio de equilíbrio, utilizando-se etanol com diferentes graus de hidratação como solvente ( 0 a $20 \%$, em massa) na faixa de temperatura de 40 a $60{ }^{\circ} \mathrm{C}$.

O planejamento dos experimentos permitiu a obtenção de modelos estatísticos através de metodologia de superfície de resposta para ambos os sistemas estudados. De maneira geral pode-se observar que, independentemente da matéria-prima, a extração de sólidos solúveis é fortemente influenciada pelo teor de água no solvente alcoólico. O aumento do teor de água no etanol suprime fortemente a extração de sólidos solúveis enquanto o aumento da temperatura somente favorece o aumento do nível de extração dos sólidos solúveis para menores teores de água no solvente. 
Foi possível observar que a hidratação da fase solvente praticamente independe da temperatura, na faixa de trabalho considerada neste capítulo $\left(40\right.$ a $\left.60^{\circ} \mathrm{C}\right)$. De fato, observa-se que existe um equilíbrio entre a umidade do sólido e o nível de hidratação do solvente etanol.

Em relação ao índice de retenção, pode-se observar que esta variável depende não somente do nível de hidratação do solvente, mas também da conformação do sólido. Os valores para RI para o pellet de farelo de arroz são de 30 a $44 \%$ menores que os obtidos para a soja em lâminas.

A análise estatística possibilitou a seleção de condições de processo, temperatura e hidratação do etanol, que possibilitem a maximização da extração de sólidos solúveis e gamaorizanol e a minimização da retenção e da extração de acidez livre. De maneira geral, a regressão não-linear apresentou desvio médio de $5 \%$. 


\section{CAPÍTULO 4}

\section{ANÁliSE TERMODINÂMICA do}

Processo de Extração Alcoólica E INFLUÊNCIA DE VARIÁVEIS DE

Processo no Índice de Retenção e Propriedades Físicas: FaiXa de Temperatura de 60 A $90{ }^{\circ} \mathrm{C}$. 


\subsection{Considerações Iniciais}

Neste capítulo da tese foi realizada uma análise termodinâmica do processo de extração para a matéria-prima soja laminada, a qual possibilitou delimitar os valores das variáveis temperatura e hidratação do solvente que conferem espontaneidade ao processo de extração.

Além da análise termodinâmica são apresentados resultados decorrentes da realização de dois planejamentos fatoriais completos para as matérias-primas soja laminada e farelo de arroz em pellets. Para a primeira matéria-prima foi realizado um planejamento considerando duas variáveis, teor de água no solvente etanol (0 a $13 \%$, em massa) e uma faixa de temperatura $\left(60\right.$ a $\left.90{ }^{\circ} \mathrm{C}\right)$ mais elevada que a utilizada no capítulo 3 .

No caso do planejamento experimental para a matéria-prima farelo de arroz, quatro variáveis independentes foram consideradas, teor de água no solvente alcoólico (0 a $24 \%$, em massa), temperatura de extração $\left(60\right.$ a $\left.90{ }^{\circ} \mathrm{C}\right)$, velocidade de agitação do extrator (100 a 250 rpm) e razão solvente: farelo (2,5 a 4,5).

Nesta fase do trabalho as respostas de interesse foram: transferências de compostos lipídicos e água, além do monitoramento dos valores das propriedades físicas, densidade e viscosidade, das fases extrato geradas. Estas informações foram correlacionadas com as respostas de índice de retenção possibilitando o cálculo do índice de retenção modificado.

Esta etapa do estudo do processo de extração possibilitou a publicação de um artigo em periódico internacional (Rodrigues, Aracava e Abreu, International Journal of Food Science and Technology, 45, 2407, 2414) além de dois trabalhos completos em eventos internacionais.

\subsection{Resultados e Discussão}

\subsubsection{Análise termodinâmica do processo de extração com solvente}

Neste capítulo da tese é realizada a análise termodinâmica do processo de extração de óleo de soja utilizando solvente. Para isso, foram determinados experimentalmente os coeficientes de distribuição do óleo de soja, calculados de acordo com a equação 2.17 (Capítulo 2), os quais são mostrados na Tabela 4.1. 
Tabela 4.1 - Efeitos da hidratação do solvente e temperatura de processo no coeficiente de distribuição do óleo de soja.

\begin{tabular}{|c|c|c|c|c|c|}
\hline \multirow[b]{3}{*}{ Temperatura $\left({ }^{\circ} \mathbf{C}\right)$} & \multicolumn{5}{|c|}{ Coeficiente de distribuição do óleo $\left(k_{\text {óleo }}\right)^{a}$} \\
\hline & \multicolumn{5}{|c|}{ Conteúdo de água no solvente $(\% \text { em massa })^{b}$} \\
\hline & $0,06 \pm 0,07$ & $1,85 \pm 0,06$ & $5,97 \pm 0,08$ & $10,39 \pm 0,01$ & $12,56 \pm 0,81$ \\
\hline 50,0 & $1,52 \pm 0,12$ & $1,05 \pm 0,07$ & $0,46 \pm 0,03$ & $0,28 \pm 0,01$ & n.d. ${ }^{\mathrm{c}}$ \\
\hline 60,0 & $2,82 \pm 0,20$ & $2,61 \pm 0,08$ & $0,94 \pm 0,07$ & $0,36 \pm 0,03$ & $0,40 \pm 0,01$ \\
\hline 64,4 & $3,94 \pm 0,28$ & $3,46 \pm 0,07$ & $1,34 \pm 0,09$ & $0,46 \pm 0,03$ & $0,45 \pm 0,02$ \\
\hline 75,0 & $13,94 \pm 0,42$ & $5,92 \pm 0,41$ & $3,31 \pm 0,23$ & $1,02 \pm 0,07$ & $0,86 \pm 0,05$ \\
\hline 85,6 & $48,47 \pm 1,45$ & $17,31 \pm 0,87$ & n.d. & $1,95 \pm 0,14$ & $1,44 \pm 0,07$ \\
\hline 90,0 & n.d. & n.d. & $6,91 \pm 0,21$ & n.d. & $1,55 \pm 0,03$ \\
\hline 100,0 & n.d. & n.d. & n.d. & $4,95 \pm 0,21$ & n.d. \\
\hline
\end{tabular}

${ }^{\mathrm{a}, \mathrm{b}}$ Valor médio \pm desvio padrão $(\%) .{ }^{\mathrm{c}}$ não determinado.

Os dados apresentados na Tabela 4.1 permitiram graficar os valores do logaritmo natural do coeficiente de partição do óleo versus o inverso da temperatura absoluta. Estes dados foram submetidos a ajuste linear sendo obtidos altos valores para os coeficientes de correlação dos modelos lineares (maiores que 0,99) para todas as condições experimentais estudadas (equação 2.17, Capítulo 2).

As variações de entalpia $\left(\Delta \mathrm{H}^{\circ}\right)$ e entropia $\left(\Delta \mathrm{S}^{\circ}\right)$ foram obtidas dos coeficientes angulares e lineares, respectivamente, das respectivas regressões lineares. A Tabela 4.2 apresenta os resultados obtidos.

Tabela 4.2 - Parâmetros termodinâmicos do processo de extração.

\begin{tabular}{ccc}
\hline $\begin{array}{c}\text { Conteúdo de água no solvente } \\
\left(\boldsymbol{\%} \text { em massa) }{ }^{\mathbf{a}}\right.\end{array}$ & $\Delta \mathbf{H}^{\mathbf{o}}\left(\mathbf{J} \cdot \mathbf{m o l}^{\mathbf{- 1}}\right)$ & $\Delta \mathbf{S}^{\mathbf{o}}\left(\mathbf{J} \cdot \mathbf{m o l}^{\left.\mathbf{1} \cdot \mathbf{K}^{\mathbf{1}}\right)}\right.$ \\
\hline $0,06 \pm 0,07$ & 95392,12 & 296,27 \\
$1,85 \pm 0,06$ & 72091,28 & 223,66 \\
$5,97 \pm 0,08$ & 68288,79 & 204,89 \\
$10,39 \pm 0,01$ & 60476,35 & 174,28 \\
$12,56 \pm 0,81$ & 48221,80 & 136,85 \\
\hline
\end{tabular}

${ }^{\mathrm{a}}$ Valor médio \pm desvio padrão $(\%)$. 
Como pode ser observado na Tabela 4.2, as mudanças de entalpia e entropia foram positivas para todos os solventes estudados, o que indica a natureza endotérmica do processo de extração de óleos.

De acordo com a teoria de dissolução aplicada à extração com solventes (Johnson e Lusas, 1983), o processo de dissolução envolve a mistura de duas ou mais substancias ocasionando um aumento na desordem e, consequentemente, a ocorrência de uma variação positiva da entropia. Os resultados apresentados na Tabela 4.2 mostram que a variação da entropia diminuiu com o aumento do conteúdo de água no solvente. De fato, para altos conteúdos de água no solvente é esperado um menor número de moléculas de óleo transferindo-se da fase sólida para a fase líquida e, consequentemente, uma menor desordem. Os valores dos coeficientes de distribuição mostrados na Tabela 4.1 reforçam este comportamento. Os valores positivos para a variação da entropia estão de acordo com trabalhos prévios publicados por Liauw et al. (2008), Meziane e Kadi (2008) e Topallar e Geçgel (2000).

Ibemesi e Attah (1990) reportaram variação na entalpia na faixa de 4-13,5 $\mathrm{kJ} \cdot \mathrm{mol}^{-1}$, para o processo de extração de óleo de semente de melão utilizando diferentes solventes. Topallar e Geçgel (2000) determinaram a variação de entalpia de $11,2 \mathrm{~kJ} \cdot \mathrm{mol}^{-1}$ para o processo de extração de óleo de semente de girassol utilizando como solventes soluções de hexano acidificadas. Meziane e Kadi (2008) estudaram o processo de extração de óleo a partir da torta resultante da prensagem de azeitonas. Neste estudo os autores utilizaram como solvente etanol com $6 \%$ água, sendo determinada uma variação entálpica de $12,91 \mathrm{~kJ} \cdot \mathrm{mol}^{-1}$.

Pode ser observado que os resultados de variação de entalpia reportados por estes autores (Topallar e Geçgel, 2000; Liauw et al., 2008; Meziane e Kadi, 2008; Ibemesi e Attah, 1990) são menores que os resultados obtidos neste trabalho (Tabela 4.2). As diferenças podem ser explicadas pelas diferentes razões sólido/solvente utilizadas nestes trabalhos: $60 \mathrm{~g}$ de sólido para $300 \mathrm{~mL}$ de solvente (Ibemesi e Attah, 1990); 10 g sólido para $200 \mathrm{~mL}$ de solvente (Topallar e Geçgel, 2000); $1 \mathrm{~g}$ de sólido para $5 \mathrm{~mL}$ de solvente (Liauw et al., 2008). De fato, as razões sólido/solvente variaram de 1:5 para 1:20 (massa:volume), enquanto neste trabalho foi utilizada uma razão de 1:2,8 (em massa). Liauw et al. (2008) reportam valores para variação de entalpia na faixa de 75-115 kJ· $\mathrm{mol}^{-1}$, razão sólido:solvente de 1:5, para o processo de extração de óleo de nim (Neem oil) usando etanol como solvente.

Na Tabela 4.2 pode ser observado que os valores de variação de entalpia decrescem à medida que o teor de água no solvente aumenta. De fato, seria esperado que solventes com alto conteúdo de água apresentassem altos valores de variação de entalpia. 
De acordo com a teoria da dissolução (Johnson e Lusas, 1983), o fenômeno de extração compreende três etapas, duas endotérmicas e uma exotérmica. Primeiramente, as moléculas do soluto são separadas em moléculas isoladas em um processo endotérmico. Nesta etapa, quando as moléculas do soluto são apolares, o montante requerido de energia é pequeno. Em seguida, as moléculas são dispersas no solvente. De fato, as moléculas do solvente precisam se dissociar para acomodar as moléculas de soluto, e a energia requerida para esta etapa aumenta à medida que as interações intermoleculares aumentam. Para esta segunda etapa, seria esperado um aumento no requerimento de energia com o aumento do nível de hidratação do solvente.

Em adição, a quantidade de energia requerida para o processo será tão maior quanto maior a molécula de soluto, uma vez que mais ligações intermoleculares entre as moléculas de solvente deverão ser rompidas para permitir a acomodação das moléculas de solvente. $\mathrm{Na}$ terceira etapa, a qual se caracteriza como um processo exotérmico, as moléculas dispersas de soluto interagem com as moléculas de solvente liberando energia. A quantidade de energia liberada aumenta de acordo com o tipo de interação soluto-solvente (quantidade baixa para moléculas de solvente e soluto apolares e quantidade de energia alta para sistemas nos quais as moléculas de soluto são solvatadas pelas moléculas de solvente).

Com base nestas informações, pode-se inferir que solventes com baixo teor de água são mais efetivos na extração de óleo devido ocasionarem maiores variações de entropia, o que resulta em variações negativas de energia livre (equação 2.18 do Capítulo 2). A Figura 4.1 apresenta a variação da energia livre como função da temperatura para todos os solventes estudados. 


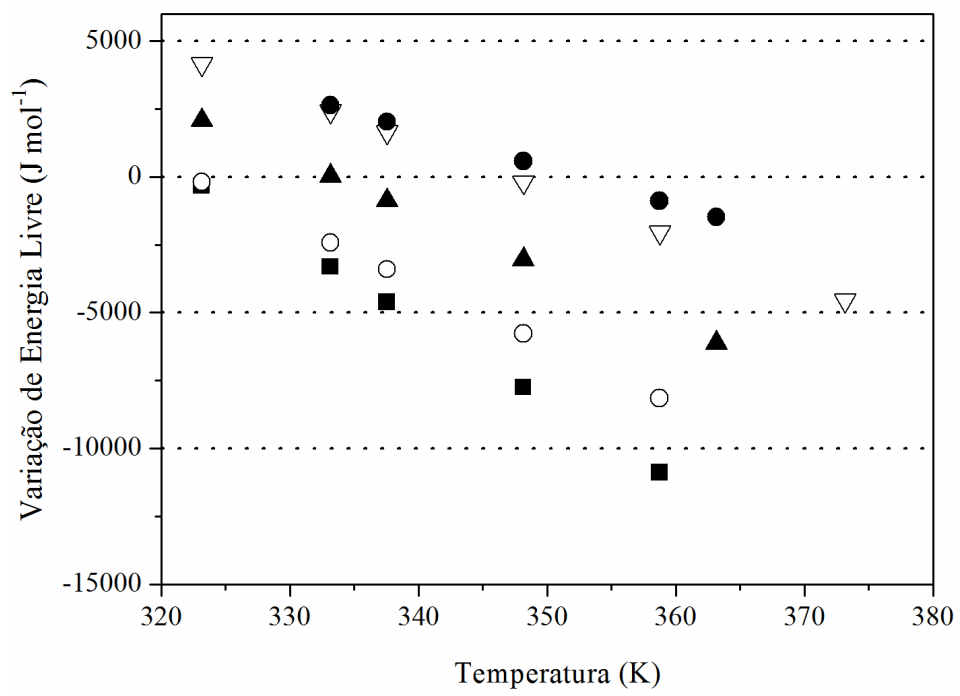

Figura 4.1 - Variação da energia livre de Gibbs como função da temperatura. Conteúdo de água no solvente: ( $\square$ ) 0,06 $\pm 0,07 \%$ em massa; (O) 1,85 $\pm 0,06 \%$ em massa; ( $\triangle$ ) 5,97 $\pm 0,08 \%$ em massa; ( $\nabla)$ 10,39 $\pm 0,01 \%$ em massa; ( $) 12,56 \pm 0,81$ $\%$ em massa.

Através da Figura 4.1 pode ser observado que para os solventes com baixo teor de água foram observadas variações negativas para a energia livre, para todas as condições experimentais estudadas. Em relação ao solvente com cerca de 6\% de água em massa, etanol grau azeotrópico, pode ser observado que para utilizá-lo como solvente a temperatura do processo deve ser superior a $333,15 \mathrm{~K}\left(60{ }^{\circ} \mathrm{C}\right)$. Pode-se inferir que sob condições de maior temperatura, o termo entrópico torna-se dominante e, consequentemente, o processo de dissolução torna-se espontâneo (equação 2.18). Para baixos valores de temperatura, o termo dominante é o termo entálpico e a dissolução, para os sistemas contendo altos conteúdos de água, não é espontânea.

\subsubsection{Análise estatística do processo de extração para a matéria-prima soja laminada}

Para a matéria-prima soja laminada foi realizado um planejamento experimental consistindo de 11 experimentos planejados para se obter um modelo quadrático composto de $2^{2}$ experimentos mais uma configuração estrela (ou pontos axiais) com quatro repetições no ponto central (Tabela 2.2 do Capítulo 2).

A Tabela 4.3 apresenta todas as combinações das variáveis estudadas na análise estatística e as correspondentes respostas. 
Tabela 4.3 - Planejamento experimental $\left(2^{2}+4\right.$ pontos axiais +4 pontos centrais $)$ referente à soja laminada.

\begin{tabular}{|c|c|c|c|c|c|c|c|c|c|c|c|c|}
\hline \multirow[t]{2}{*}{$\operatorname{Exp}$} & \multicolumn{2}{|c|}{$\begin{array}{c}\text { Variáveis } \\
\text { codificadas }\end{array}$} & \multicolumn{2}{|c|}{$\begin{array}{c}\text { Variáveis } \\
\text { reais }\end{array}$} & \multicolumn{8}{|c|}{ Respostas } \\
\hline & $\mathbf{X}_{1}$ & $X_{2}$ & $\mathrm{X}_{1}{ }^{\mathrm{a}}$ & $\mathbf{X}_{2}{ }^{b}$ & Rend $^{c}$ & $T_{\text {Água }}{ }^{d}$ & $\mathbf{T}_{\text {Sol }}{ }^{d}$ & $T_{\mathrm{AGL}}{ }^{d}$ & Água $_{F E}{ }^{e}$ & $R^{f}{ }^{f}$ & $\rho_{\mathrm{FE}} \mathrm{g}$ & $\eta_{F E}^{h}$ \\
\hline 1 & -1 & -1 & 1,89 & 64,4 & 17,51 & 22,98 & 83,93 & 43,89 & 3,51 & 1,09 & 0,7677 & 0,6334 \\
\hline 2 & +1 & -1 & 10,40 & 64,4 & 7,90 & $-18,08$ & 38,38 & 39,60 & 10,23 & 1,28 & 0,7779 & 0,7038 \\
\hline 3 & -1 & +1 & 1,89 & 85,6 & 20,07 & 24,33 & 96,49 & 44,88 & 3,51 & 1,03 & 0,7507 & 0,4706 \\
\hline 4 & +1 & +1 & 10,40 & 85,6 & 15,07 & $-16,52$ & 73,29 & 48,93 & 10,30 & 1,22 & 0,7650 & 0,5417 \\
\hline 5 & $-1,414$ & 0 & 0,14 & 75,0 & 19,79 & 59,29 & 95,75 & 43,65 & 2,11 & 0,99 & 0,7561 & 0,5265 \\
\hline 6 & $+1,414$ & 0 & 13,13 & 75,0 & 10,67 & $-11,74$ & 51,77 & 38,13 & 14,34 & 1,26 & 0,7804 & 0,6579 \\
\hline 7 & 0 & $-1,414$ & 6,02 & 60,0 & 11,77 & $-3,93$ & 56,29 & 45,43 & 7,23 & 1,20 & 0,7770 & 0,7183 \\
\hline 8 & 0 & $+1,414$ & 5,96 & 90,0 & 18,69 & 1,92 & 91,65 & 48,27 & 7,37 & 1,08 & 0,7560 & 0,4857 \\
\hline 9 & 0 & 0 & 6,02 & 75,0 & 17,21 & $-1,34$ & 82,93 & 39,31 & 7,33 & 1,15 & 0,7677 & 0,5888 \\
\hline 10 & 0 & 0 & 5,91 & 75,0 & 16,56 & $-2,04$ & 79,72 & 44,23 & 7,26 & 1,21 & 0,7673 & 0,5875 \\
\hline 11 & 0 & 0 & 5,91 & 75,0 & 16,95 & $-0,80$ & 81,72 & 42,66 & 7,22 & 1,13 & 0,7673 & 0,5872 \\
\hline 12 & 0 & 0 & 5,96 & 75,0 & 16,80 & $-0,98$ & 80,92 & 42,73 & 7,46 & 1,16 & 0,7676 & 0,5894 \\
\hline
\end{tabular}


A análise estatística dos resultados experimentais apresentados na Tabela 4.3 permitiu a obtenção de modelos, equações 4.1 a 4.7, apresentados na Tabela 4.4. Estes modelos representam o rendimento da extração (g óleo / 100 g soja laminada), a transferência de água (\%), a transferência de sólidos solúveis $(\%)$, teor de água no extrato (\%, em massa), a retenção (em $\mathrm{kg}$ de extrato $/ \mathrm{kg}$ de fibras) e as densidades $\left(\mathrm{g} \cdot \mathrm{cm}^{-3}\right)$ e viscosidades $(\mathrm{mPa} \cdot \mathrm{s})$ das fases extrato, respectivamente, como função das variáveis estatisticamente significativas para o planejamento referente à matéria-prima soja laminada.

Tabela 4.4 - Modelos estatísticos para a matéria-prima soja laminada.

\begin{tabular}{|c|c|}
\hline Modelo $^{\text {a }}$ & Equação \\
\hline Rend $(g$ óleo/loo g soja $)=16,9-3,4 X_{1}-0,9 X_{1}^{2}+2,4 X_{2}-0,9 X_{2}^{2}+1,2 X_{1} X_{2}$ & $(4.1)$ \\
\hline$T_{\text {Agua }}(\%)=-1,4-22,8 X_{1}+10,5 X_{1}^{2}+1,4 X_{2}-1,9 X_{2}^{2}$ & $(4.2)$ \\
\hline$T_{\text {Sol }}(\%)=81,3-16,6 X_{1}-5,0 X_{1}^{2}+12,3 X_{2}-3,4 X_{2}^{2}$ & (4.3) \\
\hline $\operatorname{Água}_{F E}(\%)=7,3+3,9 X_{1}+0,2 X_{1}^{2}-0,2 X_{2}^{2}$ & (4.4) \\
\hline$R I(\mathrm{~kg} / \mathrm{kg})=1,2+0,09 X_{1}-0,04 X_{2}$ & $(4.5)$ \\
\hline$\rho_{F E}\left(g \cdot \mathrm{cm}^{-3}\right)=0,77+0,0074 X_{1}-0,0075 X_{2}$ & (4.6) \\
\hline$\eta_{F E}(m P a \cdot s)=0,59+0,041 X_{1}-0,082 X_{2}$ & (4.7) \\
\hline
\end{tabular}

Com relação à resposta $\mathrm{T}_{\mathrm{AGL}}$ não foi possível a obtenção de um modelo estatístico uma vez que as variações impostas às variáveis independentes não afetaram significativamente os resultados. O valor médio obtido para a resposta transferência de ácidos graxos livres foi de $(43,5 \pm 3,3) \%$.

A Tabela 4.5 apresenta a análise de variância (ANOVA) para as respostas referentes à extração de óleo de soja. Nesta Tabela pode-se observar que os coeficientes de correlação para os modelos referentes à extração de óleo de soja variaram de 97 to $99 \%$ e os valores dos desvios relativos médios, calculados de acordo com a equação 2.3, foram aceitáveis (não maiores que 4,63\%) para as respostas rendimento, transferência de sólidos solúveis, teor de água no extrato e índice de retenção.

Com relação à resposta transferência de água, foi obtido baixo valor para o teste $\mathrm{F}$, além de um alto DRM, o que indica que o modelo apresentado na equação 4.2 deve ser utilizado 
somente para fins qualitativos. $\mathrm{O}$ mesmo tipo de comportamento para $\mathrm{T}_{\text {Água }}$ foi observado para o sistema com farelo de arroz no Capítulo 3, na faixa de temperatura de 40 a $60{ }^{\circ} \mathrm{C}$ (equação 3.4).

Através dos modelos apresentados nas Equações 4.1 a 4.7 (Tabela 4.4) foi possível gerar curvas de contorno que representam a influência das variáveis independentes selecionadas nas diferentes respostas.

As curvas de contorno referentes às respostas rendimento de extração, transferência de sólidos solúveis e transferência de água são apresentadas nas Figuras 4.2 a 4.4, respectivamente.

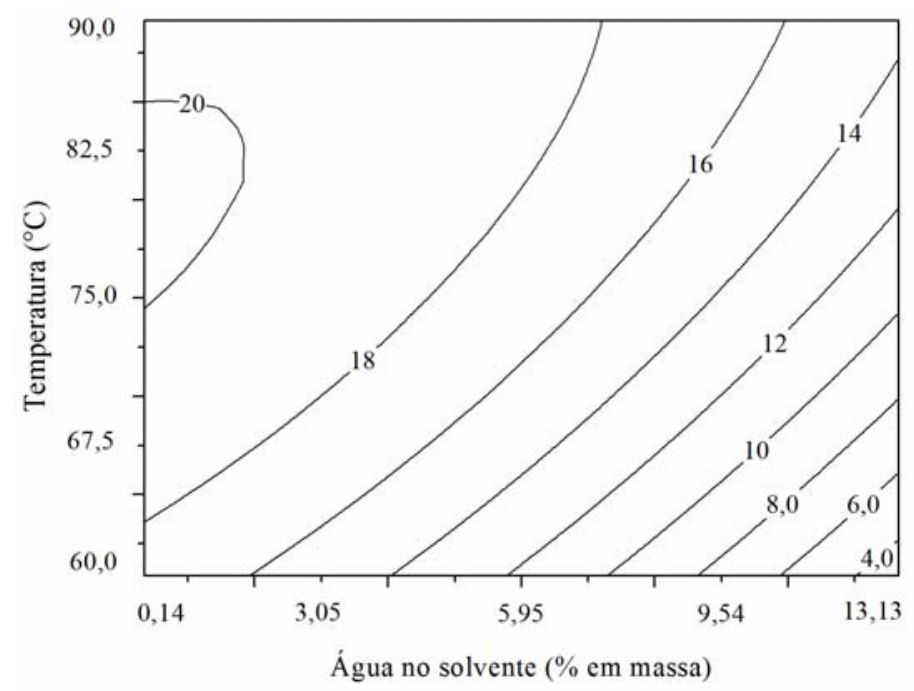

Figura 4.2 - Curvas de contorno para Rendimento de extração (Rend) como função da temperatura $\left({ }^{\circ} \mathrm{C}\right)$ e teor de água no solvente (\% em massa) para o sistema com soja laminada.

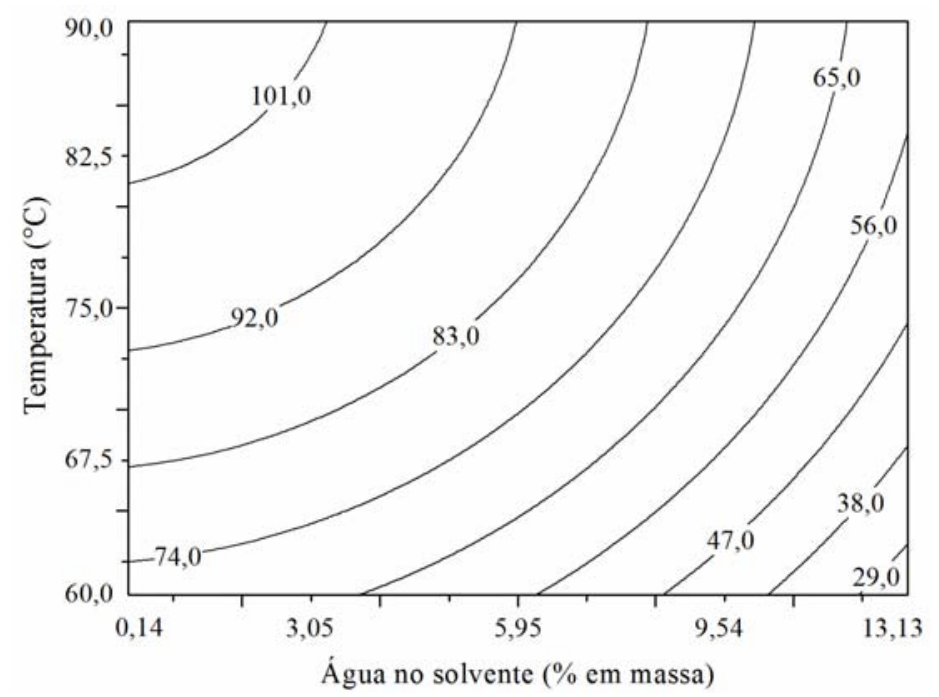

Figura 4.3 - Curvas de contorno para Transferência de sólidos solúveis $\left(T_{\text {Sol }}\right)$ como função da temperatura $\left({ }^{\circ} \mathrm{C}\right)$ e teor de água no solvente (\% em massa) para o sistema com soja laminada. 
Tabela 4.5 - Análise de variância (ANOVA) para a matéria-prima soja laminada (análise a $95 \%$ de confiança).

\begin{tabular}{|c|c|c|c|c|c|c|c|}
\hline \multirow{2}{*}{ Fonte de variação } & Rend. & $\mathbf{T}_{\text {Agua }}(\%)$ & $\mathbf{T}_{\text {Sol }}(\%)$ & Água $_{F E}$ & $\mathbf{R I}$ & $\rho_{\mathrm{FE}}$ & $\eta_{F E}$ \\
\hline & $\mathbf{S Q}^{\mathbf{a}}$ & $\mathbf{S Q}^{\mathbf{a}}$ & $\mathbf{S Q}^{\mathbf{a}}$ & $\mathbf{S Q}^{\mathbf{a}}$ & $\mathbf{S Q}^{\mathbf{a}}$ & $\mathbf{S Q}^{\mathbf{a}}$ & $\mathbf{S Q}^{\mathbf{a}}$ \\
\hline Regressão & 154,67 & 4818,13 & 3639,0 & 119,3 & 0,079 & 0,00088 & 0,067 \\
\hline Total & 156,57 & 5132,55 & 3751,2 & 122,8 & 0,084 & 0,00091 & 0,067 \\
\hline $\mathrm{F}$ valor ( $\mathrm{F}$ tabelado) & $259,95(5,1)$ & $39,10(6,2)$ & $43,1(4,1)$ & $93,5(4,1)$ & $792,9(4,3)$ & $127,7(4,3)$ & $521,1(4,3)$ \\
\hline $\operatorname{DRM}(\%)^{\mathrm{c}}$ & 1,42 & 49,74 & 4,15 & 4,63 & 1,29 & 0,16 & 1,00 \\
\hline
\end{tabular}

${ }^{\text {a }}$ Soma quadrática. ${ }^{b}$ Coeficiente de correlação. ${ }^{c}$ Desvio relativo médio (calculado de acordo com equação 2.3, capítulo 2). 


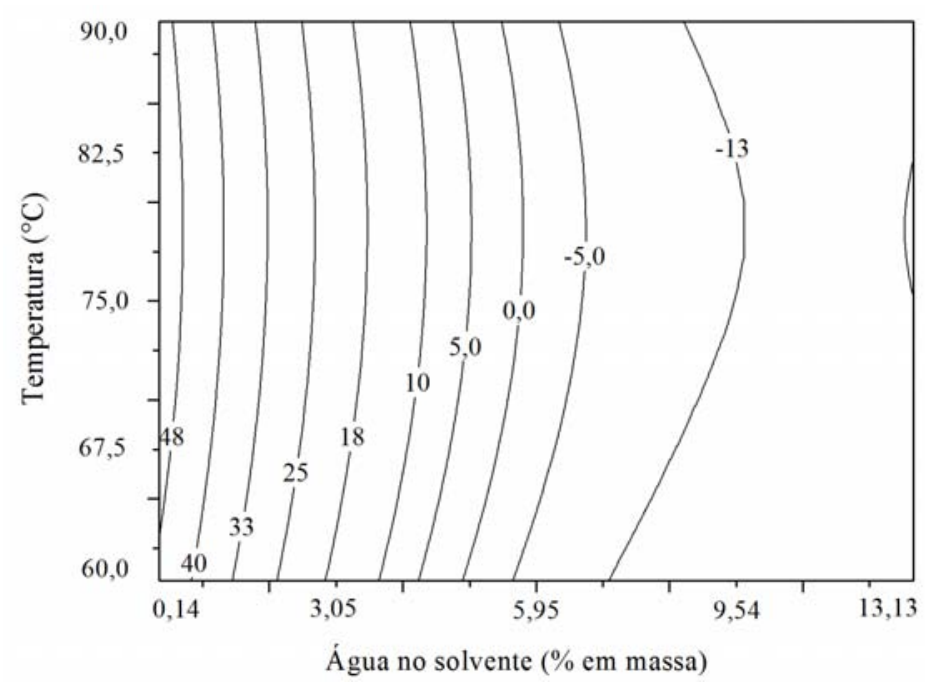

Figura 4.4 - Curvas de contorno para Transferência de água ( $T_{\text {Água }}$ ) como função da temperatura $\left({ }^{\circ} \mathrm{C}\right)$ e teor de água no solvente (\% em massa) para o sistema com soja laminada.

Na Figura 4.2 pode-se observar que o rendimento da extração é fortemente influenciado pelo teor de água no solvente. À medida que a hidratação do etanol aumenta o rendimento da extração diminui. Porém, pode-se observar que a temperatura apresenta efeito positivo sobre o rendimento da extração independentemente do teor de água no solvente. Esta observação é reforçada pelas curvas de contorno para Transferência de sólidos solúveis $\left(\mathrm{T}_{\text {Sol }}\right)$ apresentadas na Figura 4.3.

Em relação ao comportamento da resposta transferência de água, Figura 4.4, nota-se que esta resposta não é dependente da temperatura, assim como previamente observado no capítulo 3 para a matéria-prima farelo de arroz, na faixa de temperatura de 40 a $60{ }^{\circ} \mathrm{C}$ (Figura 3.4).

Na Figura 4.5 pode ser observada a dependência do conteúdo de água na fase extrato como função das variáveis independentes. 


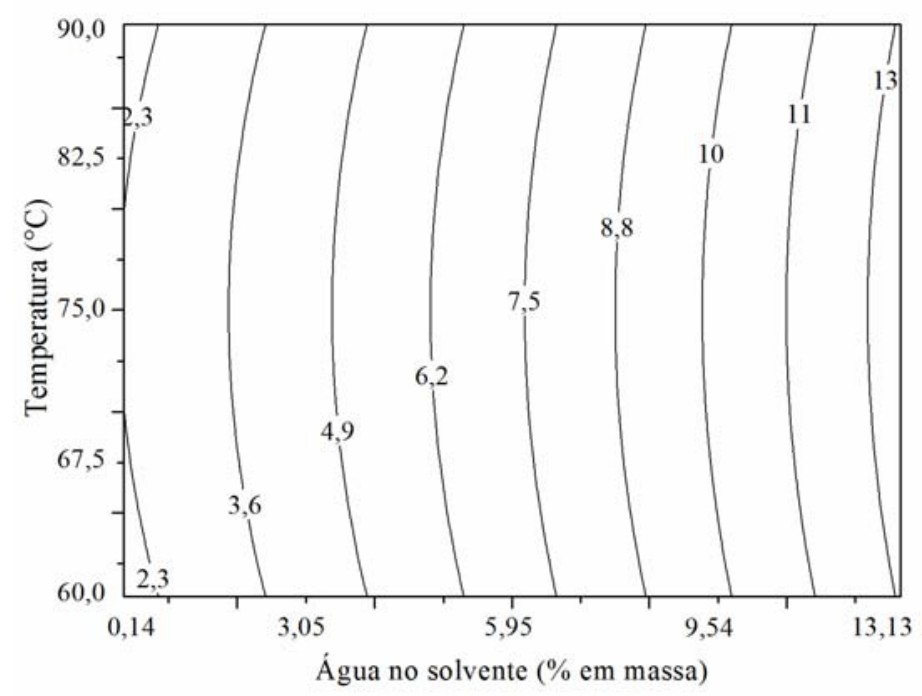

Figura 4.5 - Curvas de contorno para conteúdo de água na fase extrato (Água ${ }_{F E}$ ) como função da temperatura $\left({ }^{\circ} \mathrm{C}\right)$ e teor de água no solvente (\% em massa) para o sistema com soja laminada.

Através da análise conjunta das Figuras 4.1 a 4.5 pode-se inferir sobre a melhor associação entre as variáveis independentes, objetivando a maximização do rendimento da extração e minimização da hidratação da fase extrato.

De acordo com a Figura 4.1, temperaturas de processo acima de $80{ }^{\circ} \mathrm{C}(353,15 \mathrm{~K})$ garantem a espontaneidade do processo de extração, independentemente do teor de água na fase solvente. Na Figura 4.2 pode ser observado que para temperaturas de processo maiores que 80 ${ }^{\circ} \mathrm{C}$ foram obtidos valores de rendimento de extração maiores que $14 \%$, para toda a faixa de hidratação de solvente estudada ( 0 a $13 \%$ em massa).

Em adição, uma análise conjunta das Figuras 4.2 e 4.4 permite inferir que o nível ótimo de hidratação do solvente é cerca de 6\%, em massa, o que ocasiona um rendimento de extração para o sistema com soja laminada de $18 \mathrm{~g}$ de óleo / $100 \mathrm{~g}$ de soja laminada, em um estágio de equilíbrio. De fato, como comentado no capítulo 3, a escolha desta condição de operação também leva em conta a etapa de recuperação do solvente presente na fase extrato. A utilização de etanol com cerca de $6 \%$ de água como solvente possibilita a recuperação do solvente presente na fase extrato por destilação simples.

Em relação ao índice de retenção para os sistemas com a matéria-prima soja laminada, o comportamento desta resposta, como função do conteúdo de água no solvente e temperatura, é apresentado na Figura 4.6. 


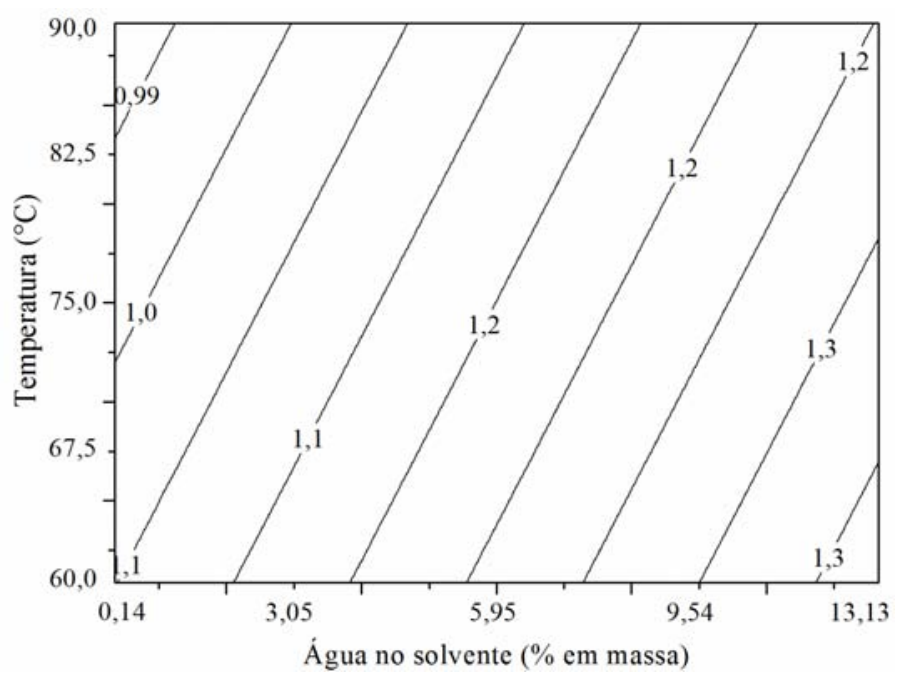

Figura 4.6 - Curvas de contorno para o Índice de Retenção (RI) como função da temperatura $\left({ }^{\circ} \mathrm{C}\right)$ e teor de água no solvente (\% em massa) para o sistema com soja laminada.

De maneira geral, como já observado no capítulo 3 (Figura 3.6, a e b, para sistemas com faelo de arroz e soja, respectivamente), nota-se que a retenção aumenta com o aumento do nível de hidratação do solvente.

Porém é possível observar que na faixa de temperatura de 60 a $90{ }^{\circ} \mathrm{C}$ o efeito da temperatura torna-se estatisticamente significativo. É possível inferir que o aumento da temperatura, para sistemas com baixo teor de água no solvente, acarreta em uma diminuição da quantidade de solução aderida à fase rafinado.

Em relação ao comportamento das densidades e viscosidades das fases extrato, equações 4.6 e 4.7, pode-se observar que os valores das propriedades físicas aumentam com o aumento do teor de água na fase solvente. Entretanto, à medida que a temperatura de processo aumenta os valores das propriedades físicas, densidade e viscosidade, diminuem (Figuras 4.7 e 4.8, respectivamente). 


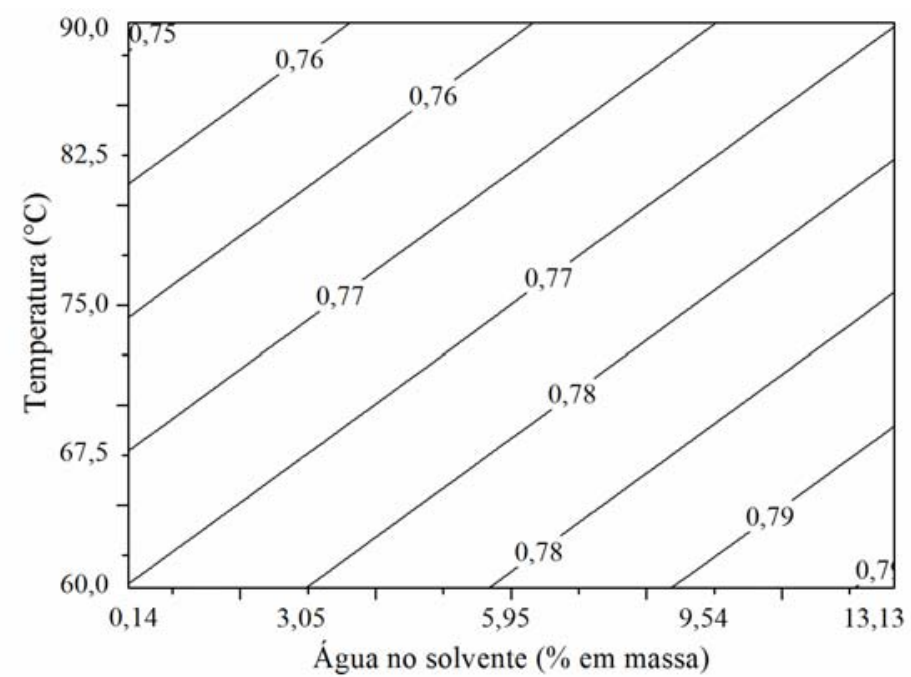

Figura 4.7 - Curvas de contorno para a Densidade da fase extrato $\left(\rho_{F E}\right)$ como função da temperatura $\left({ }^{\circ} \mathrm{C}\right)$ e teor de água no solvente (\% em massa) para o sistema com soja laminada.

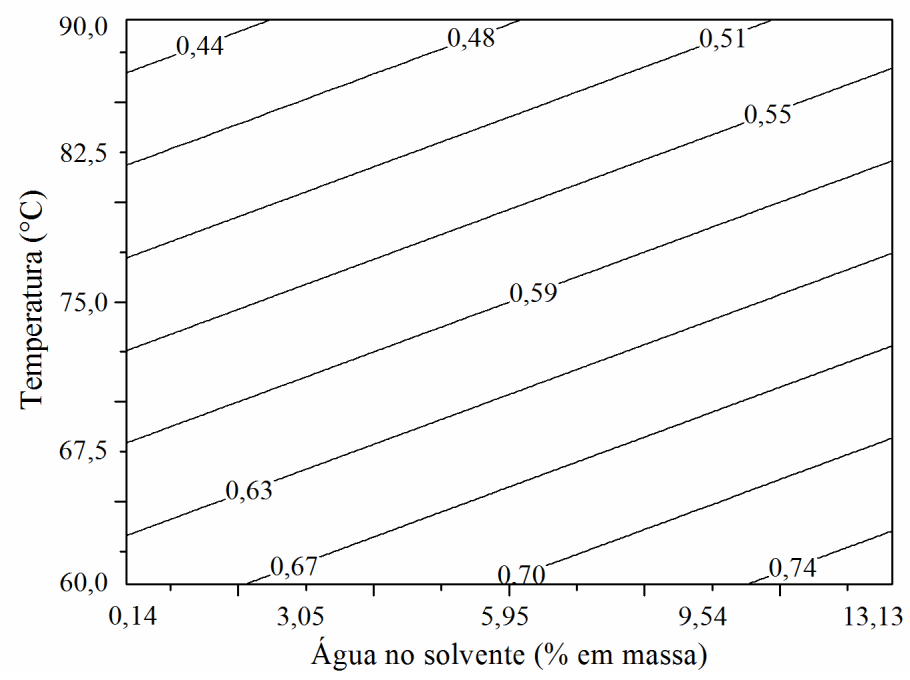

Figura 4.8 - Curvas de contorno para a Viscosidade da fase extrato $\left(n_{F E}\right)$ como função da temperatura $\left({ }^{\circ} \mathrm{C}\right)$ e teor de água no solvente (\% em massa) para o sistema com soja laminada.

\subsubsection{Análise estatística do processo de extração para a matéria-prima farelo de arroz}

Para a matéria-prima farelo de arroz em pellets foi realizado um planejamento experimental consistindo de 29 experimentos planejados para se obter um modelo quadrático composto de $2^{4}$ experimentos mais uma configuração estrela (ou pontos axiais) com cinco repetições no ponto central (Tabela 2.3 do Capítulo 2).

A Tabela 4.6 apresenta todas as combinações das variáveis estudadas na análise estatística e as correspondentes respostas. 
Tabela 4.6 - Planejamento experimental $\left(2^{4}+8\right.$ pontos axiais +5 pontos centrais $)$ referente ao farelo de arroz.

\begin{tabular}{|c|c|c|c|c|c|c|c|c|c|c|c|c|c|c|}
\hline \multirow[t]{2}{*}{$\operatorname{Exp}$} & \multicolumn{4}{|c|}{ Variáveis codificadas } & \multicolumn{4}{|c|}{ Variáveis reais } & \multicolumn{6}{|c|}{ Respostas } \\
\hline & $\mathbf{X}_{1}$ & $\mathbf{X}_{2}$ & $\mathbf{X}_{\mathbf{3}}$ & $\mathbf{X}_{4}$ & $\mathbf{X}_{1}^{\mathrm{a}}$ & $\mathbf{X}_{2}^{\mathbf{b}}$ & $\mathbf{X}_{3}{ }^{c}$ & $X_{4}^{d}$ & $\mathbf{T}_{\text {Sol }}{ }^{\mathrm{e}}$ & $\mathbf{T}_{\mathrm{AGL}}{ }^{\mathrm{e}}$ & Água $_{F E}$ f & $\mathbf{R I}^{\mathrm{g}}$ & $\rho_{\mathrm{FE}}{ }^{\mathrm{h}}$ & $\eta_{F E}^{i}$ \\
\hline 1 & -1 & -1 & -1 & -1 & 6 & 67,5 & 3 & 137,5 & 74,27 & 31,35 & 6,83 & 0,77 & 0,76921 & 0,6531 \\
\hline 3 & -1 & -1 & 1 & -1 & 6 & 67,5 & 4 & 137,5 & 78,53 & 38,23 & 6,19 & 0,71 & 0,76579 & 0,6436 \\
\hline 4 & -1 & -1 & 1 & 1 & 6 & 67,5 & 4 & 212,5 & 82,67 & 33,09 & 6,84 & 0,67 & 0,76753 & 0,6465 \\
\hline 6 & -1 & 1 & -1 & 1 & 6 & 82,5 & 3 & 212,5 & 95,86 & 37,10 & 7,21 & 0,41 & 0,75850 & 0,5583 \\
\hline 7 & -1 & 1 & 1 & -1 & 6 & 82,5 & 4 & 137,5 & 98,87 & 31,28 & 6,09 & 0,74 & 0,75489 & 0,5557 \\
\hline 8 & -1 & 1 & 1 & 1 & 6 & 82,5 & 4 & 212,5 & 96,58 & 29,55 & 6,20 & 0,78 & 0,75497 & 0,5533 \\
\hline 9 & 1 & -1 & -1 & -1 & 18 & 67,5 & 3 & 137,5 & 42,56 & 30,41 & 18,01 & 1,03 & 0,79322 & 0,7306 \\
\hline 12 & 1 & -1 & 1 & 1 & 18 & 67,5 & 4 & 212,5 & 42,08 & 28,48 & 20,28 & 1,06 & 0,79749 & 0,7278 \\
\hline 13 & 1 & 1 & -1 & -1 & 18 & 82,5 & 3 & 137,5 & 44,53 & 26,25 & 21,96 & 1,11 & 0,79155 & 0,5983 \\
\hline 14 & 1 & 1 & -1 & 1 & 18 & 82,5 & 3 & 212,5 & 49,76 & 35,81 & 18,35 & 1,03 & 0,78309 & 0,5901 \\
\hline 15 & 1 & 1 & 1 & -1 & 18 & 82,5 & 4 & 137,5 & 49,32 & 32,43 & 22,13 & 1,16 & 0,79089 & 0,5916 \\
\hline 16 & 1 & 1 & 1 & 1 & 18 & 82,5 & 4 & 212,5 & 53,03 & 36,81 & 17,27 & 0,96 & 0,77913 & 0,5829 \\
\hline 17 & 0 & 0 & 0 & 0 & 12 & 75 & 3,5 & 175 & 66,61 & 30,24 & 12,28 & 0,85 & 0,77429 & 0,6155 \\
\hline 18 & 0 & 0 & 0 & 0 & 12 & 75 & 3,5 & 175 & 67,18 & 32,74 & 12,98 & 0,88 & 0,77604 & 0,6130 \\
\hline 19 & 0 & 0 & 0 & 0 & 12 & 75 & 3,5 & 175 & 68,96 & 32,62 & 12,41 & 0,87 & 0,77482 & 0,6164 \\
\hline
\end{tabular}




\section{Tabela 4.6 (continuação)}

\begin{tabular}{|c|c|c|c|c|c|c|c|c|c|c|c|c|c|c|}
\hline \multirow[t]{2}{*}{ Exp } & \multicolumn{4}{|c|}{ Variáveis codificadas } & \multicolumn{4}{|c|}{ Variáveis reais } & \multicolumn{6}{|c|}{ Respostas } \\
\hline & $\mathbf{X}_{1}$ & $\mathbf{X}_{2}$ & $\mathbf{X}_{\mathbf{3}}$ & $\mathbf{X}_{4}$ & $\mathbf{X}_{1}^{\mathrm{a}}$ & $\mathbf{X}_{2}^{\mathbf{b}}$ & $\mathbf{X}_{3}{ }^{\mathbf{c}}$ & $X_{4}^{d}$ & $\mathbf{T}_{\text {Sol }}{ }^{e}$ & $\mathbf{T}_{\mathrm{AGL}}{ }^{\mathrm{e}}$ & Água $_{F E}{ }^{f}$ & RI $^{g}$ & $\rho_{\mathrm{FE}}{ }^{\mathrm{h}}$ & $\eta_{\mathrm{FE}}{ }^{\mathrm{i}}$ \\
\hline 20 & 0 & 0 & 0 & 0 & 12 & 75 & 3,5 & 175 & 73,52 & 35,53 & 12,44 & 0,88 & 0,77522 & 0,6130 \\
\hline 22 & -2 & 0 & 0 & 0 & 0 & 75 & 3,5 & 175 & 88,68 & 31,01 & 4,39 & 0,67 & 0,75723 & 0,5649 \\
\hline 23 & 2 & 0 & 0 & 0 & 24 & 75 & 3,5 & 175 & 46,24 & 32,34 & 22,82 & 1,24 & 0,79877 & 0,6775 \\
\hline 25 & 0 & 2 & 0 & 0 & 12 & 90 & 3,5 & 175 & 84,72 & 31,24 & 12,27 & 0,81 & 0,76393 & 0,5182 \\
\hline 26 & 0 & 0 & -2 & 0 & 12 & 75 & 2,5 & 175 & 60,26 & 29,19 & 12,49 & 0,51 & 0,77632 & 0,6305 \\
\hline 27 & 0 & 0 & 2 & 0 & 12 & 75 & 4,5 & 175 & 65,07 & 30,92 & 12,29 & 0,83 & 0,77320 & 0,6123 \\
\hline 28 & 0 & 0 & 0 & -2 & 12 & 75 & 3,5 & 100 & 58,29 & 32,45 & 11,78 & 0,84 & 0,77274 & 0,6184 \\
\hline
\end{tabular}


Na Tabela 4.7 são apresentadas as equações 4.8 a 4.12, as quais representam os modelos estatísticos para a transferência de sólidos solúveis (\%), de AGL (\%), teor de água no extrato (\%, em massa), retenção (em $\mathrm{kg}$ de extrato / $\mathrm{kg}$ de fibras) e as densidades $\left(\mathrm{g} \cdot \mathrm{cm}^{-3}\right)$ e viscosidades $(\mathrm{mPa} \cdot \mathrm{s})$ das fases extrato, referentes ao planejamento para a matéria-prima farelo de arroz.

Tabela 4.7 - Modelos estatísticos para a matéria-prima farelo de arroz.

\begin{tabular}{|c|c|}
\hline Modelo $^{\text {a }}$ & Equação \\
\hline$T_{\text {Sol }}(\%)=66,6-16,7 X_{1}+6,9 X_{2}+1,2 X_{3}+1,2 X_{4}-3,7 X_{1} X_{2}-0.9 X_{1} X_{3}+0,7 X_{2} X_{3}$ & $(4.8)$ \\
\hline Água $_{F E}(\%)=12,5+5,7 X_{1}+0,4 X_{1}^{2}+0,3 X_{1} X_{2}-0,4 X_{1} X_{4}-0,3 X_{2} X_{3}-0,7 X_{2} X_{4}$ & (4.9) \\
\hline $\begin{array}{l}R I(K g / K g)=0,8+0,2 X_{1}+0,03 X_{1}^{2}-0,006 X_{2}-0,001 X_{2}^{2}+0,05 X_{3}-0,03 X_{4} \\
+0,03 X_{1} X_{2}+0,02 X_{2} X_{3}-0,02 X_{2} X_{4}+0,02 X_{3} X_{4}\end{array}$ & $(4.10)$ \\
\hline $\begin{array}{l}\rho_{F E}\left(g \cdot \mathrm{cm}^{-3}\right)=0,77+0,013 X_{1}+0,00094 X_{1}^{2}-0,0051 X_{2}-0,00088 X_{3}-0,00049 X_{4} \\
\quad+0,00076 X_{1} X_{2}+0,00064 X_{1} X_{3}-0,00098 X_{1} X_{4}-0,00058 X_{2} X_{3} \\
\quad-0,0018 X_{2} X_{4}\end{array}$ & (4.11) \\
\hline $\begin{array}{l}\eta_{F E}(m P a \cdot s)=0,62+0,026 X_{1}+0,0019 X_{1}^{2}-0,057 X_{2}+0,0068 X_{2}^{2}-0,0024 X_{3} \\
\quad+0,0019 X_{3}^{2}-0,00094 X_{4}+0,0015 X_{4}^{2}-0,0077 X_{1} X_{2}+0,0011 X_{1} X_{3} \\
\quad-0,0026 X_{1} X_{4}+0,0030 X_{3} X_{4}\end{array}$ & $(4.12)$ \\
\hline
\end{tabular}

Como observado no item 4.2.2 para a soja, no caso do farelo de arroz também não foi possível a obtenção de um modelo estatístico para a resposta $\mathrm{T}_{\mathrm{AGL}}$. Neste caso, o valor médio obtido foi de $(32,5 \pm 3,5) \%$.

A Tabela 4.8 apresenta a análise de variância (ANOVA) para as respostas referentes à extração de óleo de farelo de arroz. Nesta Tabela nota-se que os valores para os desvios relativos médios não ultrapassaram 7,7\% e os coeficientes de correlação foram elevados (92 a 98 \%). Em adição, todos os valores de F calculados foram maiores que os respectivos tabelados, indicando que os modelos podem ser utilizados para fins preditivos (Box et al., 1978; Khuri e Cornell, 1987). 
Capítulo 4-Análise do Processo de Extração na faixa de temperatura de 60 a $90^{\circ} \mathrm{C}$

Tabela 4.8 - Análise de variância (ANOVA) para a matéria-prima farelo de arroz (análise a $95 \%$ de confiança).

\begin{tabular}{|c|c|c|c|c|c|}
\hline \multirow{2}{*}{ Fonte de variação } & $\mathrm{T}_{\text {Sol }}(\%)$ & Água $_{\text {FE }}$ & $\mathbf{R I}$ & $\rho_{\mathrm{FE}}$ & $\eta_{\mathrm{FE}}$ \\
\hline & $\mathbf{S Q}^{\mathbf{a}}$ & $\mathbf{S Q}^{\mathbf{a}}$ & $\mathbf{S Q}^{\mathbf{a}}$ & $\mathbf{S Q}^{\mathbf{a}}$ & $\mathbf{S Q}^{\mathbf{a}}$ \\
\hline Regressão & 8115,18 & 804,41 & 0,83 & 0,0047 & 0,097 \\
\hline Resíduos & 864,87 & 30,98 & 0,15 & 0,00014 & 0,0011 \\
\hline Total & 8980,05 & 835,39 & 0,97 & 0,0048 & 0,098 \\
\hline F valor (F tabelado) & $28,2(2,5)$ & $95,2(2,6)$ & $10,0(2,4)$ & $60,7(2,5)$ & $117,6(2,4)$ \\
\hline $\mathrm{CC}^{\mathrm{b}}$ & 0,95 & 0,98 & 0,92 & 0,99 & 0,99 \\
\hline $\operatorname{DRM}(\%)^{\mathrm{c}}$ & 7,64 & 7,17 & 7,66 & 0,23 & 0,75 \\
\hline
\end{tabular}

${ }^{a}$ Soma quadrática. ${ }^{b}$ Coeficiente de correlação. ${ }^{c}$ Desvio relativo médio (calculado de acordo com equação 2.3, capítulo 2). 
Através dos modelos apresentados nas Equações 4.8 a 4.12 (Tabela 4.7) foi possível gerar curvas de contorno que representam a influência das variáveis independentes selecionadas nas diferentes respostas.

A transferência de sólidos solúveis como função das variáveis independentes é apresentada na Figura 4.9. Nesta análise as variáveis razão mássica solvente: farelo e velocidade de agitação foram mantidas no nível zero do planejamento experimental (Tabela 4.6), ou seja, 3,5:1 and $175 \mathrm{rpm}$, respectivamente.

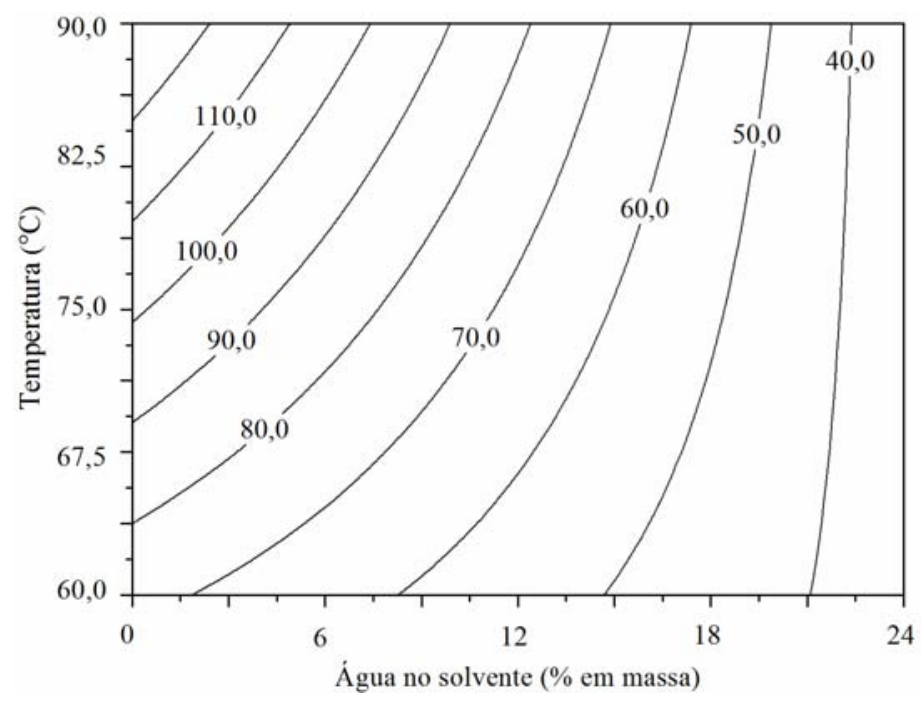

Figura 4.9 - Curvas de contorno para Transferência de sólidos solúveis $\left(T_{\text {Sol }}\right)$ como função da temperatura $\left({ }^{\circ} \mathrm{C}\right)$ e teor de água no solvente (\% em massa) para o sistema com farelo de arroz.

Através da observação das curvas de contorno apresentadas na Figura 4.9 é possível sugerir que o efeito da variável independente temperatura somente torna-se importante para situações nas quais o conteúdo de água no solvente não ultrapassa $15 \%$. Para maiores teores de hidratação do solvente, o aumento da temperatura não promove aumento significativo na extração de óleo. Este tipo de comportamento foi previamente observado no capítulo 3, para as matérias-primas farelo de arroz e soja, em condições mais amenas de temperatura, 40 a 60 ${ }^{\circ} \mathrm{C}$ (Figura 3.1).

A comparação entre as Figuras 4.3 e 4.9, para soja e farelo de arroz, respectivamente, corrobora as observações anteriores. Na Figura 4.3 pode-se observar um efeito positivo da temperatura sobre a extração de sólidos solúveis, independentemente do teor de água no solvente (menores que 13\%).

Em artigo publicado em 1983, Johnson e Lusas comentam que a solubilidade dos óleos vegetais em etanol é dependente da temperatura de processo e hidratação do solvente. 
Os autores reportam que o óleo de soja é miscível com etanol absoluto, em qualquer proporção, em temperaturas acima de $70{ }^{\circ} \mathrm{C}$. No caso da utilização de etanol hidratado, a solubilidade do óleo é fortemente reduzida e uma completa miscibilidade não é possível, mesmo no ponto de ebulição do solvente (Johnson e Lusas, 1983).

Folegatti-Romero et al. (2010) publicaram dados de solubilidade mútua em sistemas contendo óleo de soja ou de farelo de arroz e etanol absoluto. Os autores mostram que as temperaturas críticas de solução para os sistemas binários óleo vegetal/solvente são $69,1{ }^{\circ} \mathrm{C}$ para o sistema com soja e $66,9^{\circ} \mathrm{C}$ para o sistema com óleo de farelo de arroz.

Rao et al. (1955) determinaram valores para solubilidade de óleo de soja e óleo de amendoim em solventes com 0,2 e 4,6 \% de água. Para estes sistemas, os valores determinados para as temperaturas críticas foram 67,78 e $90{ }^{\circ} \mathrm{C}$, respectivamente, para o óleo de soja e 70,80 , e $95^{\circ} \mathrm{C}$, respectivamente, para o óleo de amendoim.

Na Figura 4.3 é possível visualizar que para temperaturas de processo entre 75 e $80^{\circ} \mathrm{C}$ é possível transferir para a fase extrato todo o óleo de soja disponível na matriz sólida quando etanol absoluto é utilizado como solvente.

A temperatura de $75{ }^{\circ} \mathrm{C}$ é relativamente próxima aos valores propostos por FolegattiRomero et al. (2010) e Rao et al. (1955), com desvios relativos de 7,9 e 10,7\%, respectivamente, para a matéria-prima soja.

No caso da matéria-prima farelo de arroz (Figura 4.9) pode-se observar que a $75^{\circ} \mathrm{C}$, para o sistema com etanol absoluto, é possível transferir $100 \%$ de todo o óleo contido na matriz sólida para a fase extrato. Da mesma forma que o comentado anteriormente para a soja, a temperatura de $75^{\circ} \mathrm{C}$ é relativamente próxima ao valor proposto por Folegatti-Romero et al. (2010), com desvio relativo de 10,8\%. Considerando que os óleos de farelo de arroz e amendoim apresentam grande similaridade em termos de composição em ácidos graxos, pode-se comparar os dados de solubilidade determinados por Rao et al. (1955) com os apresentados na Figura 4.9, com desvio relativo de 6,7\%.

De fato, é importante enfatizar que o mecanismo de extração do óleo da matriz sólida envolve uma sequência de etapas: a transferência do solvente sobre a superfície sólida, a penetração do solvente na matriz sólida por difusão, dissolução do soluto, difusão da solução composta por soluto e solvente para a superfície, e transferência da solução a partir da superfície para o seio da solução, por convecção natural ou forçada (Takeuchi et al., 2009).

No entanto, os dados publicados por Folegatti-Romero et al. (2010) e Rao et al. (1955) são exclusivamente baseadas na dissolução do óleo. Portanto, diferenças são esperadas na temperatura necessária para garantir a completa dissolução do óleo. 
Na Figura 4.10 pode-se observar a dependência do conteúdo de água na fase extrato como função das variáveis independentes.

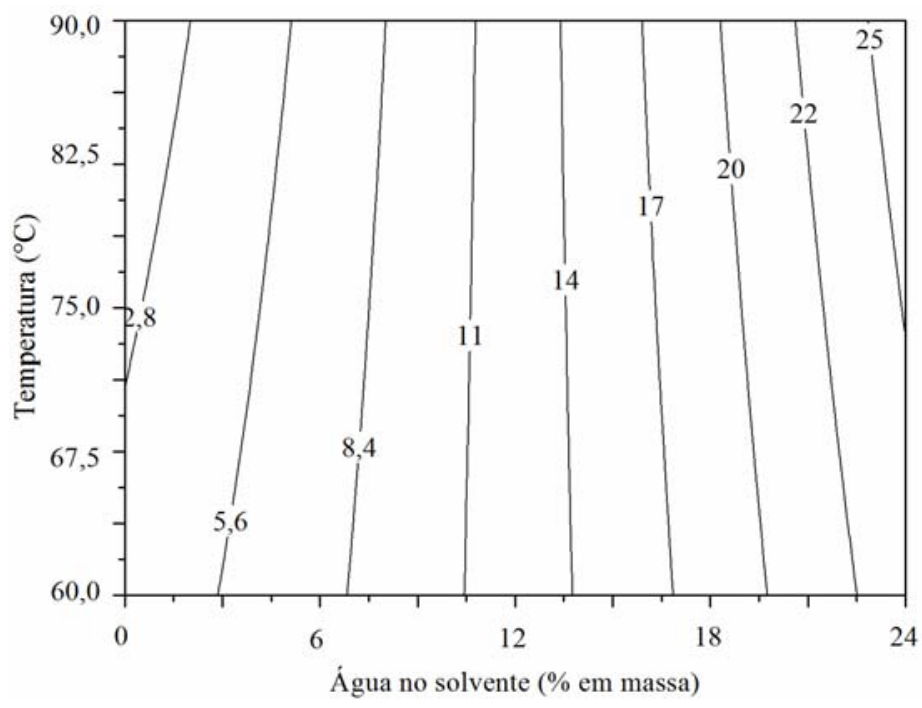

Figura 4.10 - Curvas de contorno para conteúdo de água na fase extrato (Água ${ }_{F E}$ ) como função da temperatura $\left({ }^{\circ} \mathrm{C}\right)$ e teor de água no solvente (\% em massa) para o sistema com farelo de arroz.

O comportamento da resposta conteúdo de água na fase extrato (Figura 4.10) corrobora os comentários prévios sobre a baixa influência da temperatura sobre o processo de hidratação da fase extrato (Figuras 3.4, 4.4 e 4.5).

De fato, pode-se concluir que o processo de hidratação da fase extrato depende somente da umidade inicial do sólido e do nível de água presente no solvente, para uma ampla faixa de temperatura 40 a $90{ }^{\circ} \mathrm{C}$.

O comportamento do índice de retenção como função do conteúdo de água no solvente e temperatura, é apresentado na Figura 4.11. Nesta análise os valores das variáveis razão mássica solvente: farelo e velocidade de agitação foram mantidos no nível zero do planejamento experimental (vide Tabela 4.7), ou seja, 3,5:1 e $175 \mathrm{rpm}$, respectivamente. 


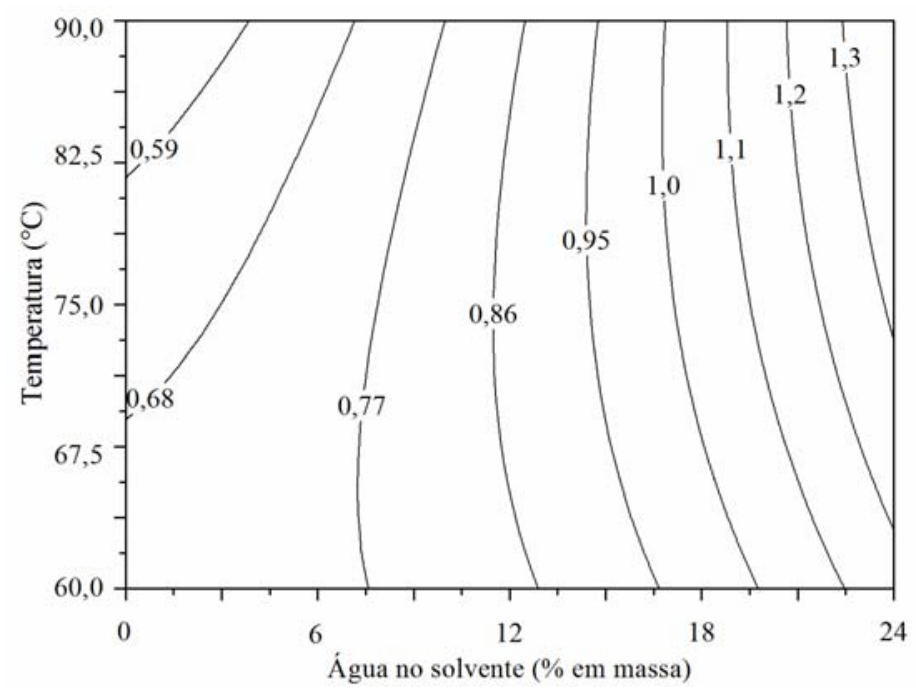

Figura 4.11 - Curvas de contorno para o Índice de Retenção (RI) como função da temperatura $\left({ }^{\circ} \mathrm{C}\right)$ e teor de água no solvente (\% em massa) para o sistema com farelo de arroz.

De maneira geral, como já observado no capítulo 3, nota-se que a retenção aumenta com o aumento do nível de hidratação do solvente. No entanto, como previamente observado na Figura 4.6, na faixa de temperatura de 60 a $90{ }^{\circ} \mathrm{C}$ o efeito da temperatura torna-se estatisticamente significativo sendo possível observar uma diminuição da quantidade de solução aderida à fase rafinado com o aumento da temperatura, para sistemas com baixo teor de água no solvente (valores menores que 6\% de água no etanol).

A Figura 4.12, (a) e (b), apresenta a dependência do índice de retenção em relação às variáveis razão mássica solvente: farelo e teor de água no solvente e velocidade de agitação (rpm) e teor de água no solvente, respectivamente. Nestes casos, os valores das outras variáveis independentes foram mantidos no nível zero.

É possível observar que a retenção aumenta à medida que a oferta de solvente no sistema aumenta. Por outro lado, nota-se que o aumento da velocidade de agitação acarreta em uma redução no hold-up de líquido. 


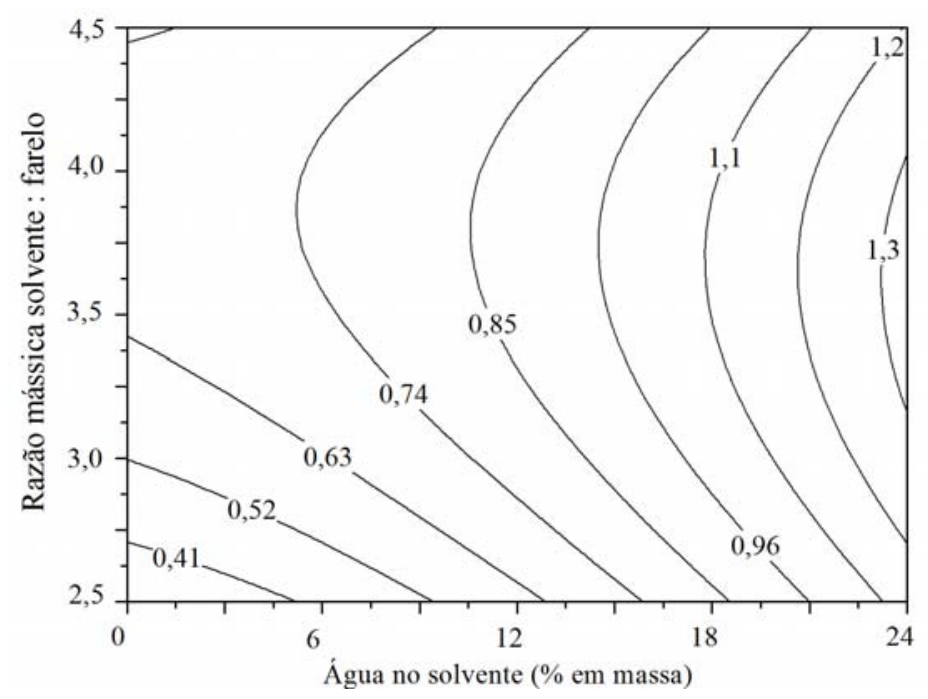

a)

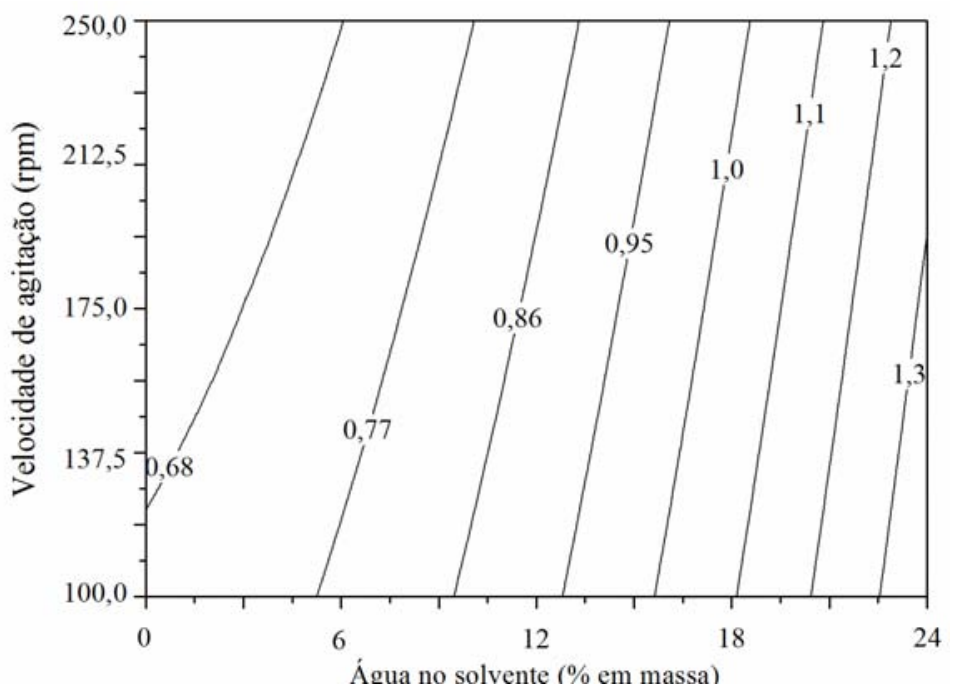

b)

Figura 4.12 - Curvas de contorno para retenção (RI) nos sistemas com farelo de arroz: a) como função da razão mássica solvente: farelo $(\mathrm{m} / \mathrm{m})$ e teor de água no solvente (\% em massa); b) como função da velocidade de agitação (rpm) e teor de água no solvente (\% em massa).

As Figuras 4.13 e 4.14 apresentam as curvas de contorno para as respostas densidade e viscosidade da fase extrato como função do conteúdo de água no solvente e temperatura. Nesta análise os valores das variáveis razão mássica solvente: farelo e velocidade de agitação foram mantidos no nível zero do planejamento experimental (vide Tabela 4.6), ou seja, 3,5:1 e $175 \mathrm{rpm}$, respectivamente. 


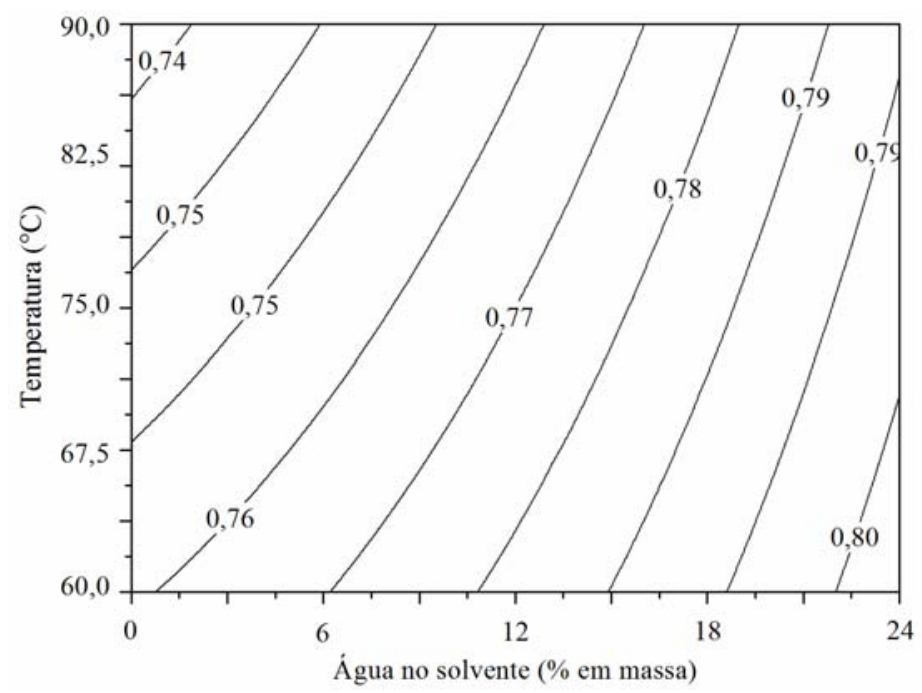

Figura 4.13 - Curvas de contorno para a Densidade da fase extrato $\left(\rho_{F E}\right)$ como função da temperatura $\left({ }^{\circ} \mathrm{C}\right)$ e teor de água no solvente (\% em massa) para o sistema com farelo de arroz.

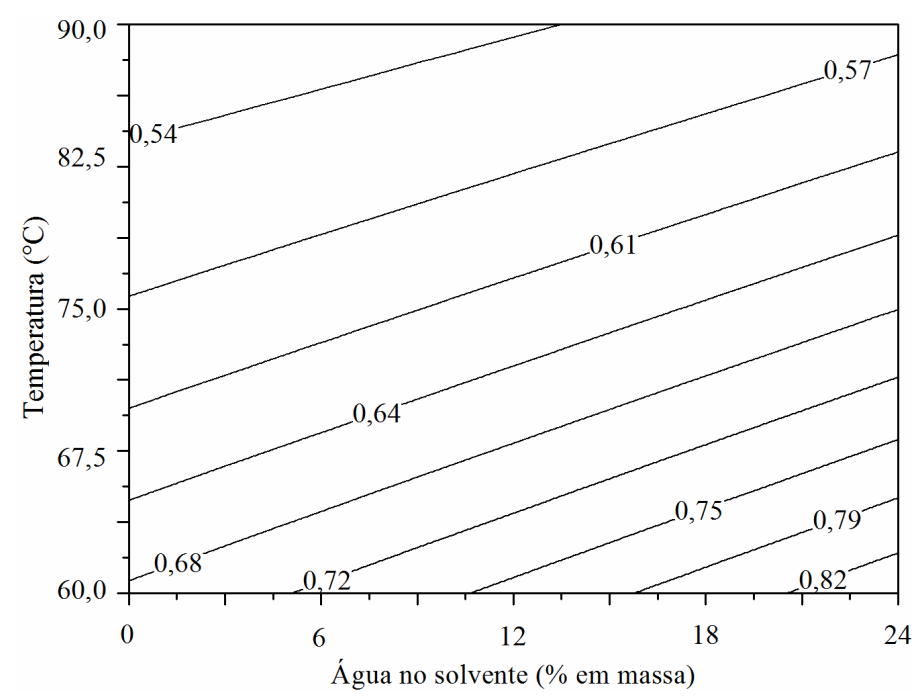

Figura 4.14 - Curvas de contorno para a Viscosidade da fase extrato $\left(n_{F E}\right)$ como função da temperatura $\left({ }^{\circ} \mathrm{C}\right)$ e teor de água no solvente $(\%$ em massa) para o sistema com farelo de arroz.

Os valores das propriedades físicas, densidade e viscosidade da fase extrato, aumentam com o aumento do teor de água na fase solvente e, por outro lado, os valores diminuem à medida que a temperatura de processo aumenta. Os resultados apresentados para a matéria-prima farelo de arroz estão de acordo com os resultados prévios apresentados para a matéria-prima soja (Figuras 4.7 e 4.8 ).

Os comportamentos observados para as propriedades físicas estão de acordo com as dependências da densidade e viscosidade dos compostos puros em relação à temperatura, como pode ser observado na Figura 4.15. De fato, esta figura apresenta as densidades e 
viscosidades dos compostos puros - água, etanol absoluto, etanol com 6\% de água em massa e óleos degomados de soja e farelo de arroz - como função da temperatura.
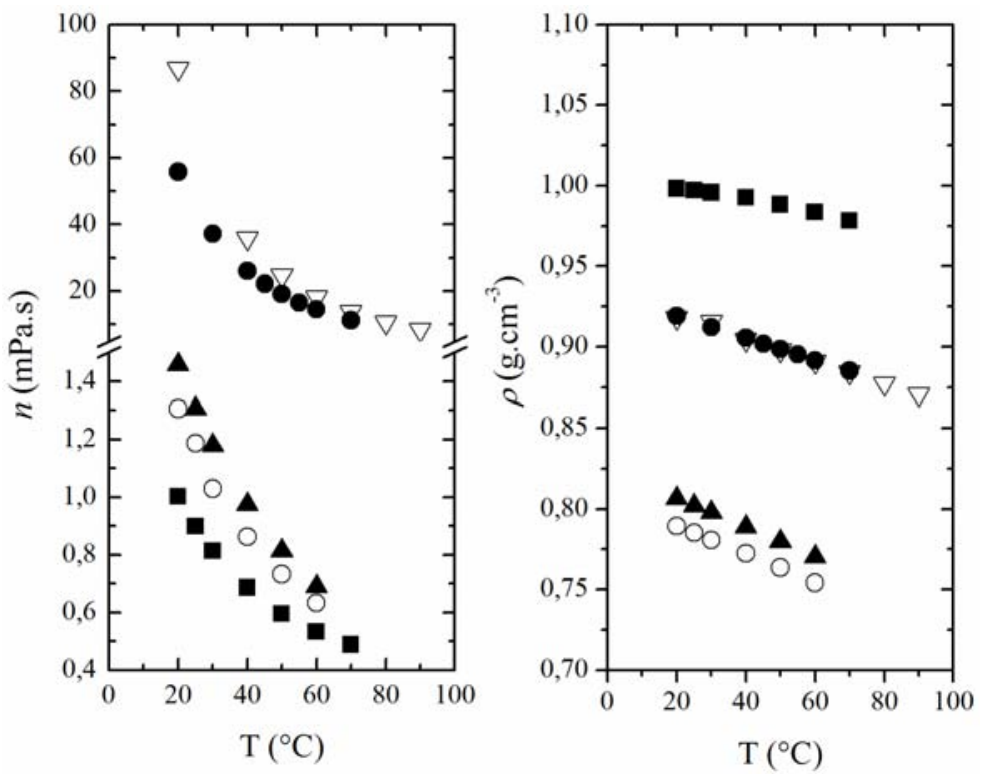

Figura 4.15 - Viscosidades $(\eta)$ e densidades $(\rho)$ como função da temperatura $\left({ }^{\circ} \mathrm{C}\right)$ para os

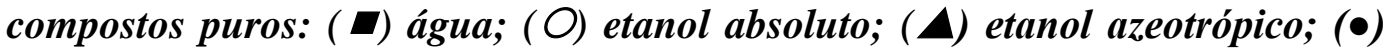
óleo de soja degomado; ( $\nabla)$ óleo de farelo de arroz degomado.

Na Figura 4.15 é possível notar que, embora a água apresente valores de viscosidade menores que os apresentados pelo etanol absoluto, os valores de viscosidade para o etanol com 6\% de água (etanol azeotrópico) são maiores do que os obtidos para os outros compostos puros (água e etanol absoluto). Estes resultados estão de acordo com dados publicados por Belda et al. (2004). Neste trabalho, os autores sugerem que este comportamento está baseado no fenômeno de solvatação do álcool. Fenômeno resultante de pontes de hidrogênio formadas entre moléculas de etanol e água, o que resulta em um aumento do volume molar da nova estrutura formada. De acordo com os autores, este aumento do volume molar acarreta em um aumento da viscosidade e densidade do sistema. 


\subsection{4. Índice de retenção e propriedades físicas}

Alguns trabalhos disponíveis na literatura relacionam o índice de retenção com as propriedades físicas da fase extrato (Kocatas e Cornell, 1954; Wisniak et al., 1987). Wisniak et al. (1987) estudaram o processo de extração de óleo de jojoba utilizando hexano e isopropanol como solventes. Neste trabalho, os autores propuseram, baseando-se em trabalho prévio de Kocatas e Cornell (1954), que o índice de retenção é inversamente proporcional à velocidade mássica com que o líquido (extrato) deixa o leito. Por outro lado, o índice de retenção é proporcional a $\left(\eta \cdot \rho^{-2}\right)$, onde $\eta$ é a viscosidade dinâmica da solução e $\rho$ é sua densidade. Wisniak et al. (1987) propuseram o uso de um índice de retenção modificado (RI*) o qual pode permitir um melhor entendimento do comportamento da variável índice de retenção. $\mathrm{O}$ índice de retenção modificado pode ser definido de acordo com a equação 4.13.

$$
R I^{*}=\frac{(R I) \cdot \eta}{\rho_{F E}^{2}}
$$

Onde RI é o índice de retenção, e $\rho_{F E}$ e $\eta_{F E}$ são a densidade e viscosidade da fase extrato, respectivamente.

Neste capítulo, dados de índice de retenção modificado (RI*) foram calculados com base nos modelos estatísticos obtidos para as respostas índice de retenção, densidade e viscosidade, para as duas matérias-primas de interesse, soja laminada e farelo de arroz (equações 4.5, 4.6 e 4.7 para a soja laminada, e equações $4.10,4.11$ e 4.12 para a matériaprima farelo de arroz).

Para o cálculo do índice de retenção modificado, os valores de temperatura foram variados para cada teor de água no solvente. No caso da matéria-prima farelo de arroz, os valores das variáveis razão mássica solvente: farelo e velocidade de agitação foram mantidas no nível codificado zero.

A Figura 4.16, (a) e (b), apresenta os valores dos índices de retenção modificados como função da viscosidade da fase extrato para diferentes níveis de água no solvente. 


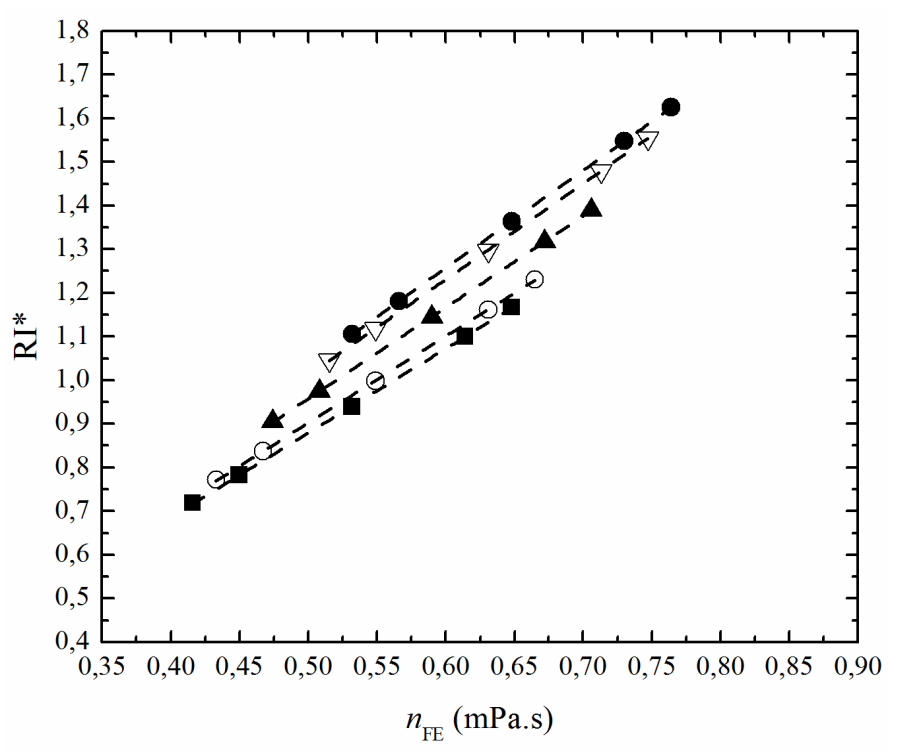

a)

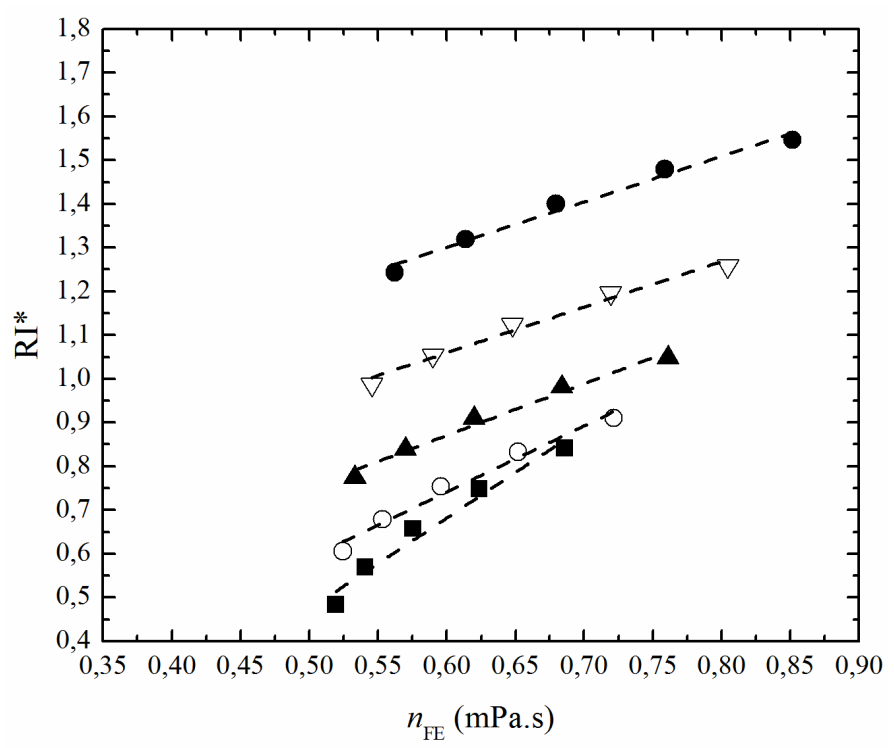

b)

Figura 4.16 - Índice de retenção modificado ( $\left.R I^{*}\right)$ como função da viscosidade da fase extrato $\left(\eta_{F E}\right)$, para diferentes conteúdos de água no solvente (\% em massa): a)

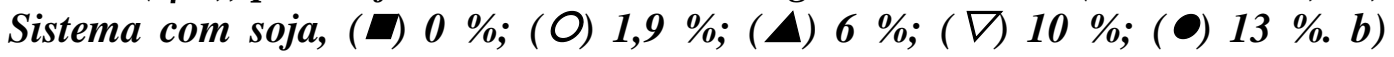

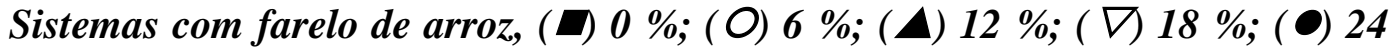
$\%$.

De acordo com a Figura 4.16, pode-se perceber que a relação entre o índice de retenção modificado e a viscosidade da fase extrato é linear para todos os solventes estudados, sendo obtidos altos coeficientes de correlação (maiores que 0,99 ) para todas as situações.

Esta relação linear permite inferir que o índice de retenção modificado aumenta com o aumento da viscosidade da fase extrato, independentemente da quantidade de água adicionada 
ao etanol. Desta forma, é possível concluir que o comportamento do índice de retenção está associado às propriedades físicas investigadas, densidade e viscosidade.

Estes comentários estão de acordo com resultados prévios publicados por Wisniak et al. (1987) e Zhang et al. (2002a). Os últimos autores estudaram a eficiência do isopropanol na extração de óleo de algodão. Foi observado que o hold-up de líquido (índice de retenção) tende a aumentar à medida que o conteúdo de óleo residual no material sólido diminui, em outras palavras, o índice de retenção aumenta à medida que a viscosidade da fase extrato aumenta (Zhang et al., 2002a).

Na Figura 4.16 é possível notar que o índice de retenção modificado (RI*) aumenta à medida que aumenta o teor de água no solvente, como previamente observado nas Figuras 4.6 e 4.11, em relação ao índice de retenção (RI) para soja e farelo de arroz, respectivamente. Pode-se sugerir, neste caso, que solventes com alto conteúdo de água apresentam maior polaridade, o que resulta em maior interação com a porção hidrofílica do sólido, proteínas e carboidratos.

De maneira geral, os valores de índice de retenção obtidos neste estudo variaram de 0,41 a 1,24 para o farelo de arroz, e de 0,99 a 1,28 para a soja (RI expresso como massa de líquido / massa de sólido).

No caso dos pellets de farelo de arroz, os valores determinados neste trabalho são superiores aos reportados para a extração de óleo de pellets de soja utilizando hexano como solvente (0,39 kg de líquido / kg de sólido) e próximos aos reportados para a extração de óleo de pellets de soja utilizando etanol azeotrópico como solvente $(0,43 \mathrm{~kg}$ de líquido / $\mathrm{kg}$ de sólido) (Rittner, 1992).

Os resultados obtidos neste trabalho são, também, próximos aos reportados por Zhang et al. (2002a) para a extração de óleo de algodão, de pellets e lâminas, utilizando álcool isopropílico hidratado (5 \% de água) como solvente $(0,49$ e $1,13 \mathrm{~kg}$ de líquido / $\mathrm{kg}$ de sólido, respectivamente) (Zhang et al., 2002a).

No capítulo 3 desta tese foram apresentados dados de índice de retenção para sistemas com farelo de arroz e soja, onde o processo de extração foi investigado na faixa de temperatura de 40 a $60{ }^{\circ} \mathrm{C}$. Foram relatados valores de índice de retenção que variaram de 0,77 to $1,12 \mathrm{~kg}$ de líquido / $\mathrm{kg}$ de sólido para sistemas com farelo de arroz e 1,27 to 1,62 kg de líquido / kg de sólido para sistemas com soja. Naquele estudo observou-se que o índice de retenção, no intervalo de 40 a $60{ }^{\circ} \mathrm{C}$, somente era dependente do nível de hidratação do solvente. 
Esta informação, associada aos resultados apresentados neste capítulo, mostra que o efeito da temperatura sobre o índice de retenção, principalmente para sistemas com baixo teor de água no solvente, é proeminente somente para temperaturas de processo acima de $60{ }^{\circ} \mathrm{C}$.

\subsection{Conclusões}

Neste capítulo da tese foi realizada a análise termodinâmica do processo de extração alcoólica de óleo de soja. Esta análise indicou que as mudanças de entalpia e entropia no processo de extração do óleo diminuem à medida que o nível de hidratação do solvente aumenta. Em temperaturas acima de $80{ }^{\circ} \mathrm{C}$ foi possível a obtenção de valores negativos para a variação de energia livre para todos os tipos de solventes estudados. Estes resultados permitem inferir que o processo de extração usando etanol como solvente é possível e espontâneo, sendo favorecido pelo aumento da temperatura.

Os dois tipos de planejamento de experimentos apresentados neste capítulo propiciaram a obtenção de modelos estatísticos preditivos para predição de transferência de compostos lipídicos, transferência de água, propriedades físicas e índice de retenção. A metodologia de superfície de resposta em conjunto com a análise estatística propiciou a seleção de faixas de valores ótimos para as variáveis independentes consideradas no estudo objetivando a maximização do rendimento da extração.

Foi possível observar que a utilização de valores de hidratação do solvente até $6 \%$ e temperaturas acima de $80{ }^{\circ} \mathrm{C}$ permite obter bons valores em termos de rendimento da extração.

Os modelos estatísticos obtidos para as respostas índice de retenção, densidade e viscosidade da fase extrato propiciaram, ainda, o cálculo do índice de retenção modificado através do qual foi possível observar que o índice de retenção aumenta com o aumento do valor da viscosidade da fase extrato. 


\section{CATÍTULO 5}

\section{INFLUÊNCIA DAS VARIÁVEIS DE}

Processo na Extração de Compostos NutracêUTICOS E COMPOSIÇÃO EM ÁCIDOS GRAXOS DO Óleo EXTRAído 


\subsection{Considerações Iniciais}

Neste capítulo é apresentado estudo referente à influência das variáveis independentes, nível de hidratação do solvente ( 0 to $24 \%$, em massa), temperatura (60 a $90{ }^{\circ} \mathrm{C}$ ), razão mássica solvente: farelo (2.5:1 a 4.5:1) e velocidade de agitação (100 a $250 \mathrm{rpm}$ ) sobre a extração de compostos minoritários de interesse, gama-orizanol e tocoferóis/tocotrienóis (nomeados de tocóis neste trabalho) e, também, sobre a composição, em ácidos graxos, dos óleos de farelo de arroz extraídos com etanol.

Esta etapa do estudo do processo de extração possibilitou a publicação de um artigo em periódico internacional (Oliveira, Oliveira, Aracava e Rodrigues, Food and Bioproducts Processing, no prelo, 2011), além de trabalhos resumidos em eventos nacionais.

\subsection{Resultados e Discussão}

A Tabela 5.1 apresenta os valores médios obtidos para as diferentes caracterizações do farelo de arroz utilizado nesta etapa do estudo.

Tabela 5.1 - Caracterização do farelo de arroz.

\begin{tabular}{cccc}
\hline & Média & Desvio padrão & CV (\%) ${ }^{\mathbf{c}}$ \\
\hline Umidade $^{\mathrm{a}}$ & 9,62 & 0,43 & 4,81 \\
Lipídeos totais $^{\mathrm{a}}$ & 22,20 & 0,06 & 0,30 \\
Proteína bruta $^{\mathrm{a}}$ & 15,04 & 0,18 & 1,20 \\
gama-Orizanol $^{\mathrm{b}}$ & 12.510 & 51 & 0,41 \\
Tocóis $^{\mathrm{b}}$ & 334 & 14 & 4,20 \\
${ }^{\text {a }}$ Porcentagem em base seca. $^{\mathrm{b}}$ Valores expressos como mg de nutracêutico / $\mathrm{kg}$ de farelo de arroz úmido. $^{\text {c }}$ \\
Coeficiente de Variância.
\end{tabular}

Os resultados apresentados na Tabela 5.1 estão de acordo com resultados prévios apresentados por Hu et al. (1996), Orthoefer (2005) e Lloyd et al. (2000).

A Tabela 5.2 apresenta a composição em ácidos graxos para o óleo de farelo de arroz extraído através da metodologia proposta por Bligh e Dyer (1959). Na Tabela 5.2 também pode ser observada a composição em ácidos graxos do óleo de farelo de arroz (Oryza sativa) publicada por Firestone (1999). Pode-se notar a similaridade entre a composição da literatura e a obtida no presente trabalho. 
Tabela 5.2 - Composição em ácidos graxos do óleo de farelo de arroz.

\begin{tabular}{|c|c|c|c|c|}
\hline Ácido graxo & $C x: y^{a}$ & $\begin{array}{c}\text { Massa molar } \\
\left(\mathrm{g} \cdot \mathrm{mol}^{-1}\right)\end{array}$ & $\begin{array}{c}\text { Bligh-Dyer } \\
\text { Massa }(\%)\end{array}$ & $\begin{array}{l}\text { Literatura }^{c} \\
\text { Massa (\%) }\end{array}$ \\
\hline Miristico & C14:0 & 228,38 & $0,85 \pm 0,71$ & $0,50-0,70$ \\
\hline Palmítico & C16:0 & 256,43 & $17,07 \pm 0,82$ & $16,00-28,00$ \\
\hline Palmitoleico & C16:1 & 254,41 & $0,00 \pm 0,00$ & 0,50 \\
\hline Estearico & C18:0 & 284,49 & $2,00 \pm 0,35$ & $2,00-4,00$ \\
\hline Oleico & C18:1 & 282,47 & $38,17 \pm 0,33$ & $38,00-48,00$ \\
\hline Linoleico & C18:2 & 280,45 & $37,48 \pm 0,70$ & $16,00-36,00$ \\
\hline Linolenico & C18:3 & 278,44 & $2,29 \pm 0,39$ & $0,20-2,20$ \\
\hline Araquidico & C20:0 & 312,54 & $0,60 \pm 0,03$ & $0,50-0,80$ \\
\hline Gadoleico & C20:1 & 310,52 & $0,40 \pm 0,07$ & $0,30-0,50$ \\
\hline Behenico & C22:0 & 340,59 & $0,36 \pm 0,42$ & $0,10-0,50$ \\
\hline Erucico & $\mathrm{C} 22: 1$ & 338,58 & $0,37 \pm 0,05$ & - \\
\hline Lignocerico & $\mathrm{C} 24: 0$ & 368,65 & $0,40 \pm 0,02$ & $0,00-0,50$ \\
\hline \multicolumn{3}{|c|}{ Massa molar média $\left(\mathrm{g} \cdot \mathrm{mol}^{-1}\right)$} & $277,8 \pm 0,7$ & $274,9 \pm 0,9$ \\
\hline \multicolumn{3}{|c|}{ Índice de iodo } & $104,1 \pm 0,7$ & $86,75 \pm 3,48$ \\
\hline \multicolumn{3}{|c|}{ Razão entre os ácidos graxos insaturados e saturados } & $3,70 \pm 0,48$ & $3,30 \pm 0,04$ \\
\hline \multicolumn{3}{|c|}{ Razão entre os ácidos linoleico e palmítico } & $2,20 \pm 0,06$ & $2,14 \pm 0,01$ \\
\hline \multicolumn{3}{|c|}{ Razão entre os ácidos oleico e linoleico } & $1,02 \pm 0,10$ & $0,93 \pm 0,01$ \\
\hline
\end{tabular}

${ }^{a}$ Em Cx:y, $\mathrm{x}=$ número de carbonos e $\mathrm{y}=$ número de duplas ligações. ${ }^{\mathrm{b}}$ Óleo extraído do farelo segundo metodologia sugerida por Bligh e Dyer (1959). ${ }^{c}$ Firestone (1999).

É importante enfatizar que ambas as composições apresentadas na Tabela 5.2 foram comparadas às composições em ácidos graxos dos óleos obtidos utilizando-se o etanol como solvente, sob diferentes condições de temperatura, hidratação do solvente, razão mássica solvente: sólido e velocidade de agitação.

Para estudar o efeito destas variáveis de processo, conteúdo de água no solvente $\left(\mathrm{X}_{1}\right)$, temperatura $\left(\mathrm{X}_{2}\right)$, razão mássica solvente: sólido $\left(\mathrm{X}_{3}\right)$ e velocidade de agitação $\left(\mathrm{X}_{4}\right)$ sobre o processo de extração, foi realizado um planejamento experimental $2^{4}+8$ pontos axiais +5 pontos centrais. A Tabela 5.3 apresenta as combinações das variáveis independentes e as respostas de interesse para este capítulo da tese. 
Tabela 5.3 - Planejamento experimental $\left(2^{4}+8\right.$ pontos axiais +5 pontos centrais $)$ para a matéria-prima farelo de arroz.

\begin{tabular}{|c|c|c|c|c|c|c|c|c|c|c|c|}
\hline \multirow[t]{2}{*}{ Exp } & \multicolumn{4}{|c|}{ Variáveis codificadas } & \multicolumn{4}{|c|}{ Variáveis reais } & \multicolumn{3}{|c|}{ Respostas } \\
\hline & $\mathbf{X}_{1}$ & $\mathbf{X}_{2}$ & $\mathbf{X}_{3}$ & $\mathbf{X}_{4}$ & $\mathbf{X}_{1}{ }^{\mathrm{a}}$ & $\mathbf{X}_{2}^{\mathbf{b}}$ & $\mathbf{X}_{\mathbf{3}}^{\mathbf{c}}$ & $\mathrm{X}_{4}^{\mathrm{d}}$ & Rend $^{\mathrm{e}}$ & Oriza $^{f}$ & Tocóis $^{f}$ \\
\hline 1 & -1 & -1 & -1 & -1 & 6 & 67,5 & 3 & 137,5 & 13,83 & 3241 & 143 \\
\hline 2 & -1 & -1 & -1 & 1 & 6 & 67,5 & 3 & 212,5 & 14,36 & 2552 & 159 \\
\hline 3 & -1 & -1 & 1 & -1 & 6 & 67,5 & 4 & 137,5 & 14,57 & 3292 & 195 \\
\hline 4 & -1 & -1 & 1 & 1 & 6 & 67,5 & 4 & 212,5 & 15,35 & 2876 & 123 \\
\hline 5 & -1 & 1 & -1 & -1 & 6 & 82,5 & 3 & 137,5 & 17,15 & 3629 & 212 \\
\hline 6 & -1 & 1 & -1 & 1 & 6 & 82,5 & 3 & 212,5 & 17,77 & 3744 & 222 \\
\hline 7 & -1 & 1 & 1 & -1 & 6 & 82,5 & 4 & 137,5 & 20,05 & 3876 & 246 \\
\hline 8 & -1 & 1 & 1 & 1 & 6 & 82,5 & 4 & 212,5 & 19,55 & 3441 & 201 \\
\hline 9 & 1 & -1 & -1 & -1 & 18 & 67,5 & 3 & 137,5 & 8,69 & 2326 & 200 \\
\hline 10 & 1 & -1 & -1 & 1 & 18 & 67,5 & 3 & 212,5 & 10,70 & 2626 & 193 \\
\hline 11 & 1 & -1 & 1 & -1 & 18 & 67,5 & 4 & 137,5 & 9,54 & 2766 & 198 \\
\hline 12 & 1 & -1 & 1 & 1 & 18 & 67,5 & 4 & 212,5 & 8,56 & 2052 & 217 \\
\hline 13 & 1 & 1 & -1 & -1 & 18 & 82,5 & 3 & 137,5 & 9,09 & 1807 & 252 \\
\hline 14 & 1 & 1 & -1 & 1 & 18 & 82,5 & 3 & 212,5 & 10,15 & 1527 & 261 \\
\hline 15 & 1 & 1 & 1 & -1 & 18 & 82,5 & 4 & 137,5 & 10,06 & 4152 & 238 \\
\hline 16 & 1 & 1 & 1 & 1 & 18 & 82,5 & 4 & 212,5 & 10,89 & 3862 & 271 \\
\hline 17 & 0 & 0 & 0 & 0 & 12 & 75 & 3,5 & 175 & 12,58 & 3005 & 166 \\
\hline 18 & 0 & 0 & 0 & 0 & 12 & 75 & 3,5 & 175 & 12,59 & 2852 & 164 \\
\hline 19 & 0 & 0 & 0 & 0 & 12 & 75 & 3,5 & 175 & 12,87 & 2596 & 184 \\
\hline
\end{tabular}




\section{Tabela 5.3 (continuação)}

\begin{tabular}{|c|c|c|c|c|c|c|c|c|c|c|c|}
\hline \multirow[t]{2}{*}{$\operatorname{Exp}$} & \multicolumn{4}{|c|}{ Variáveis codificadas } & \multicolumn{4}{|c|}{ Variáveis reais } & \multicolumn{3}{|c|}{ Respostas } \\
\hline & $\mathbf{X}_{1}$ & $\mathbf{X}_{2}$ & $\mathbf{X}_{\mathbf{3}}$ & $\mathbf{X}_{4}$ & $\mathbf{X}_{1}{ }^{a}$ & $\mathbf{X}_{2}^{\mathbf{b}}$ & $\mathbf{X}_{3}{ }^{\mathrm{c}}$ & $X_{4}^{d}$ & $\operatorname{Rend}^{\mathrm{e}}$ & Oriza $^{f}$ & Tocóis $^{f}$ \\
\hline 20 & 0 & 0 & 0 & 0 & 12 & 75 & 3,5 & 175 & 13,72 & 2500 & 178 \\
\hline 21 & 0 & 0 & 0 & 0 & 12 & 75 & 3,5 & 175 & 13,01 & 2086 & 150 \\
\hline 22 & -2 & 0 & 0 & 0 & 0 & 75 & 3,5 & 175 & 17,98 & 4164 & 135 \\
\hline 23 & 2 & 0 & 0 & 0 & 24 & 75 & 3,5 & 175 & 9,45 & 2708 & 221 \\
\hline 24 & 0 & -2 & 0 & 0 & 12 & 60 & 3,5 & 175 & 9,06 & 1848 & 109 \\
\hline 25 & 0 & 2 & 0 & 0 & 12 & 90 & 3,5 & 175 & 17,18 & 3667 & 224 \\
\hline 26 & 0 & 0 & -2 & 0 & 12 & 75 & 2,5 & 175 & 12,30 & 2113 & 162 \\
\hline 27 & 0 & 0 & 2 & 0 & 12 & 75 & 4,5 & 175 & 13,22 & 2908 & 160 \\
\hline 28 & 0 & 0 & 0 & -2 & 12 & 75 & 3,5 & 100 & 11,89 & 2554 & 138 \\
\hline 29 & 0 & 0 & 0 & 2 & 12 & 75 & 3,5 & 250 & 12,52 & 2927 & 163 \\
\hline
\end{tabular}

${ }^{\mathrm{a}}$ Conteúdo de água no solvente $\left(\%\right.$ em massa). ${ }^{\mathrm{b}}$ Temperatura $\left({ }^{\circ} \mathrm{C}\right) .{ }^{\mathrm{c}}$ razão mássica solvente: farelo $(\mathrm{m} / \mathrm{m}) .{ }^{\mathrm{d}}$ velocidade de agitação (rpm). ${ }^{\mathrm{e}} \mathrm{g}$ óleo $/ 100 \mathrm{~g}$ farelo de arroz. ${ }^{\mathrm{f}}$ mg de nutracêutico / kg de farelo de arroz. 
Na Tabela 5.4 é apresentada a análise de variância (ANOVA), a qual foi utilizada para determinar os parâmetros significativos que influenciam as respostas de interesse.

Os dados apresentados na Tabela 5.3 foram analisados estatisticamente, sendo que a significância (considerando $95 \%$ de confiança) de cada coeficiente foi determinada através dos valores de F e p. Os correspondentes valores de p sugerem que $\mathrm{X}_{1}, \mathrm{X}_{2}$ e $\mathrm{X}_{3}$ e as interações entre estas variáveis apresentam-se como termos significativos dos modelos, com valores de p menores que 0,05 . Outros termos, tais como $\mathrm{X}_{4}$ e as interações considerando esta variável, foram insignificantes para as respostas de interesse (rendimento da extração e concentração de orizanol e tocóis).

Na Tabela 5.4, pode-se observar que os coeficientes de correlação variaram de 80 a $97 \%$ enquanto os desvios relativos médios apresentaram valores aceitáveis (menores que 12\%). Desta forma, pode-se concluir que os modelos estatísticos ajustados representam a real relação entre as variáveis independentes avaliadas.

Em relação ao teste $\mathrm{F}$, pode-se observar que para a resposta Rendimento da extração (Rend), foi obtido um valor de 50,55. Este valor é maior que o tabelado $(2,55)$, o que denota que o modelo ajustado (equação 5.1, Tabela 5.5) para a resposta Rend pode ser utilizado para fins preditivos (Box et al., 1978; Khuri e Cornell, 1987).

O mesmo procedimento de análise foi utilizado para as outras respostas. As equações 5.2 e 5.3, apresentadas na Tabela 5.5, mostram os modelos codificados empíricos para as respostas Concentração de Oriza e de Tocóis (mg de nutracêutico $/ \mathrm{kg}$ de farelo de arroz). 
Tabela 5.4 - Análise de Variância (ANOVA) para a matéria-prima farelo de arroz (análise a $95 \%$ de confiança).

\begin{tabular}{|c|c|c|c|c|c|c|c|c|c|c|c|c|}
\hline \multirow{2}{*}{ Fonte de variação } & \multicolumn{4}{|c|}{ Rend } & \multicolumn{4}{|c|}{ Oriza } & \multicolumn{4}{|c|}{ Tocóis } \\
\hline & $\mathbf{S Q}^{\mathbf{a}}$ & MQ $^{b}$ & $\mathbf{G L}^{\mathrm{c}}$ & Teste $^{\mathrm{d}^{\mathrm{d}}}$ & $\mathbf{S Q}^{\mathbf{a}}$ & MQ $^{b}$ & $\mathbf{G L}^{\mathbf{c}}$ & Teste $F^{\mathbf{e}}$ & $\mathbf{S Q}^{\mathbf{a}}$ & MQ $^{b}$ & $G_{L^{c}}$ & Teste $F^{f}$ \\
\hline Regressão & 287,5 & 47,91 & 6,00 & 50,55 & 10930780 & 1821797 & 6,00 & 10,96 & 32814 & 10938 & 3,00 & 15,08 \\
\hline Resíduos & 20,85 & 0,95 & 22,00 & 5,13 & 3656912 & 166223 & 22,00 & 1,40 & 18137 & 726 & 25,00 & 4,65 \\
\hline Total & 308,3 & & 28,00 & & 14587693 & & 28,00 & & 50951 & & 28,00 & \\
\hline $\mathrm{CC}^{\mathrm{g}}$ & 0,97 & & & & 0,87 & & & & 0,80 & & & \\
\hline $\operatorname{DRM}(\%)^{\mathrm{h}}$ & 5,83 & & & & 11,59 & & & & 11,70 & & & \\
\hline
\end{tabular}

${ }^{a}$ Soma quadrática. ${ }^{\mathrm{b}}$ Média quadrática. ${ }^{c}$ Graus de liberdade. ${ }^{\mathrm{d}} \mathrm{F}_{0,95 ; 6 ; 22}=2,55 .{ }^{\mathrm{e}} \mathrm{F}_{0,95 ; 6 ; 22}=2,55 .{ }^{\mathrm{f}} \mathrm{F}_{0,95 ; 3 ; 25}=2,99 .{ }^{\mathrm{g}}$ Coeficiente de correlação. ${ }^{\mathrm{h}}$ Desvio relativo médio. 
Tabela 5.5 - Modelos estatísticos para a matéria-prima farelo de arroz.

\begin{tabular}{cc}
\hline Modelo $^{\text {a }}$ & Equação \\
\hline Rend(g óleo / $100 \mathrm{~g}$ farelo de arroz $)=13,06-3,00 X_{1}+1,47 X_{2}$ \\
$+0,36 X_{3}-0,86 X_{1} X_{2}-0,37 X_{1} X_{3}+0,37 X_{2} X_{3}$ \\
Oriza $(\mathrm{mg} / \mathrm{kg}$ farelo de arroz $)=2710-352 X_{1}+213 X_{1}^{2}+331 X_{2}+269 X_{3}$ \\
$+264 X_{1} X_{3}+274 X_{2} X_{3}$ \\
Tocóis $(m g / k g$ farelo de arroz $)=183+21 X_{1}+8 X_{1}^{2}+29 X_{2}$
\end{tabular}

${ }^{\mathrm{a}} \mathrm{X}_{1}, \mathrm{X}_{2}, \mathrm{X}_{3}$ e $\mathrm{X}_{4}$ são variáveis codificadas.

Através dos modelos apresentados nas Equações 5.1 a 5.3 (Tabela 5.5) foi possível gerar curvas de contorno que representam a influência das variáveis independentes selecionadas nas diferentes respostas. 


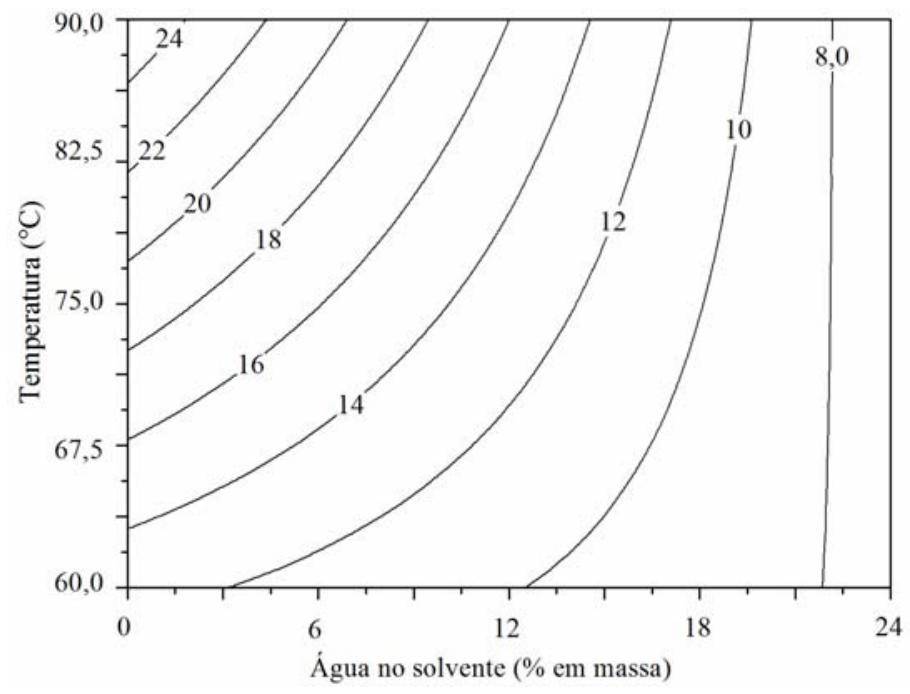

a)

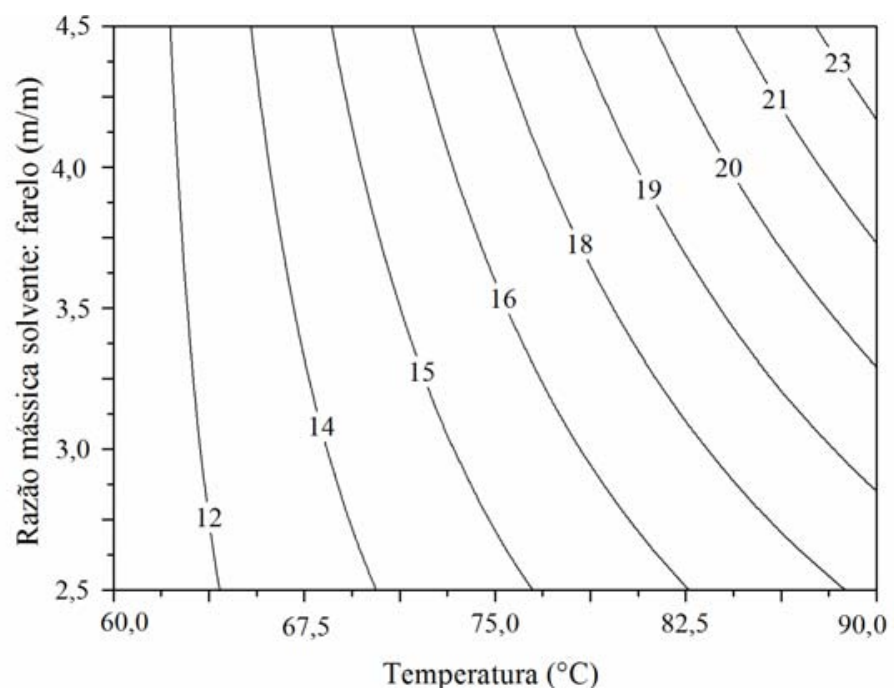

b)

Figura 5.1 - Curvas de contorno para Rendimento de extração (Rend) como função: (a) da temperatura $\left({ }^{\circ} \mathrm{C}\right)$ e teor de água no solvente $(\% \mathrm{em}$ massa), com $X_{3}=3,5$ e $X_{4}=175 \mathrm{rpm}$; (b) da temperatura $\left({ }^{\circ} \mathrm{C}\right)$ e razão solvente: sólido, com $X_{1}=6 \%$ em massa e $X_{4}=175 \mathrm{rpm}$.

Na Figura 5.1 (a) pode ser observado que o rendimento da extração é fortemente influenciado pelo conteúdo de água no solvente, como previamente observado na Figura 4.2 (Capítulo 4) para a matéria-prima soja laminada. Nesta análise os valores das variáveis razão solvente: farelo $\left(\mathrm{X}_{3}\right)$ e velocidade de agitação $\left(\mathrm{X}_{4}\right)$ foram mantidos no nível zero codificado, ou 3,5 : 1 e $175 \mathrm{rpm}$, respectivamente.

Mudanças na temperatura de processo e razão solvente: farelo revelaram que a variável independente razão solvente: farelo somente é importante em situações onde altas temperaturas são utilizadas (Figura 5.1 (b)). Neste caso, a velocidade de agitação 
foi mantida no nível zero e a hidratação do solvente no nível -1 (etanol com $6 \%$ de água em massa).

Dados de rendimento de extração de óleo de farelo de arroz (OFA) utilizando diferentes solventes são disponíveis na literatura. Proctor et al. (1994) estudaram a extração de OFA utilizando hexano como solvente em temperatura ambiente. Os autores obtiveram rendimento de aproximadamente 19,30\% de óleo, a partir de farelo com 21,25\% de óleo disponível, utilizando $20 \mathrm{~mL}$ de solvente para $2 \mathrm{~g}$ de farelo.

Em um trabalho subsequente, Proctor e Bowen (1996) compararam os desempenhos dos solventes hexano e isopropanol, sob as mesmas condições do trabalho anterior. Neste caso, o isopropanol apresentou o melhor desempenho, uma vez que possibilitou a extração de $100 \%$ de óleo comparado aos $92 \%$ para o hexano.

De fato, é importante enfatizar que os autores utilizaram altas razões solvente: farelo, 6,6:1 e 7,9:1 para hexano e isopropanol, respectivamente, considerando as densidades dos solventes a $25^{\circ} \mathrm{C}$.

No presente trabalho, foi possível obter um máximo rendimento de 20,05, que corresponde a 99\% do óleo disponível na matriz sólida utilizando um menor valor de razão solvente: sólido (condições experimentais referentes ao experimento 7 na Tabela 5.3).

Liu e Mamidipally (2005) realizaram estudo de extração de óleo de farelo de arroz utilizando limoneno como solvente. As extrações foram conduzidas utilizandose o solvente em seu ponto de ebulição $\left(162,8{ }^{\circ} \mathrm{C}\right)$ para diferentes razões solvente: sólido (de 2:1 até 5:1), obtendo-se um rendimento máximo de 22,98, que corresponde a $81 \%$. De fato, o solvente proposto pelos autores, devido ao alto ponto de ebulição, pode conduzir a um alto consumo de energia, se comparado ao hexano ou etanol.

A Figura 5.2 mostra as curvas de contorno para as respostas Concentração de Oriza e de Tocóis (mg de nutracêutico / kg de farelo de arroz), respectivamente. 


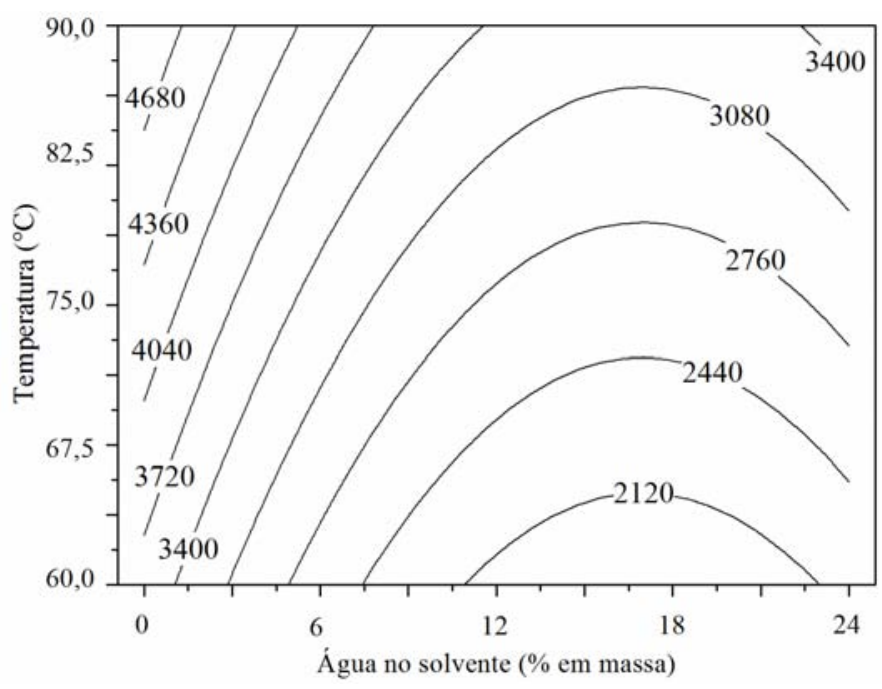

a)

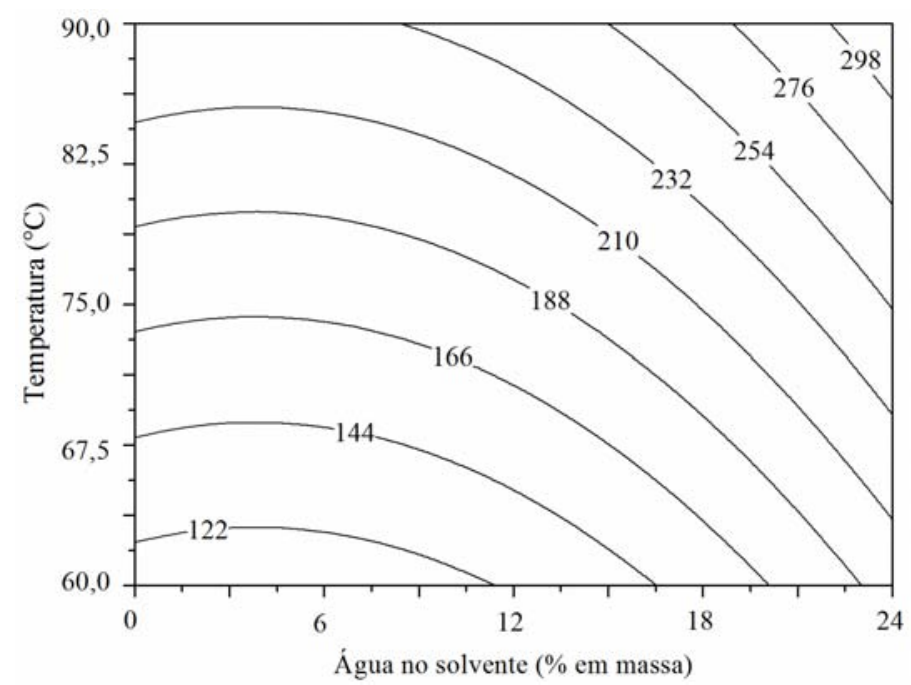

b)

Figura 5.2 - Curvas de contorno para Concentração de nutracêutico (mg / $\mathrm{kg}$ farelo de arroz) como função da temperatura $\left({ }^{\circ} \mathrm{C}\right)$ e teor de água no solvente (\% em massa), com $X_{3}=3,5$ e $X_{4}=175$ rpm: a) Orizanol; b) Tocóis.

$\mathrm{Na}$ Figura 5.2 (a) pode-se observar como as variáveis independentes temperatura e teor de hidratação do solvente afetam a extração de gama-orizanol. Nesta análise, os valores das variáveis razão solvente: sólido e velocidade de agitação foram mantidos no nível codificado zero. Pode-se observar que solventes com alto conteúdo de água mostram-se menos efetivos na extração do composto nutracêutico. É possível obervar, ainda, que o efeito da temperatura é minimizado quando solventes altamente hidratados são utilizados. 
Resultados semelhantes foram reportados no capítulo 3, no estudo do processo de extração de OFA considerando o intervalo de temperatura de 40 a $60{ }^{\circ} \mathrm{C}$ (Figura 3.3). Desta forma, pode-se inferir que altos conteúdos de água no solvente resultam em um moderado efeito da temperatura sobre o equilíbrio de fases de sistemas graxos, mesmo quando altos valores de temperatura de processo são utilizados.

Imsanguan et al. (2008) estudaram o processo de extração de gama-orizanol do farelo de arroz utilizando fluido supercrítico e extração com solvente a pressão ambiente. Neste trabalho foi possível notar que a temperatura apresentou-se como um importante fator, afetando a concentração de orizanol, tanto para o hexano como para o etanol. Os autores obtiveram extratos com $7349 \mathrm{mg}$ de orizanol $/ \mathrm{kg}$ de farelo de arroz e $9414 \mathrm{mg}$ de orizanol/kg de farelo de arroz, em base seca, para os solventes hexano e etanol, respectivamente, usando um alto valor de razão solvente: sólido, 100 $\mathrm{mL}$ para $1 \mathrm{~g}$, nas temperaturas entre 55 e $60{ }^{\circ} \mathrm{C}$ e concluíram que o etanol mostrou-se mais eficiente que o hexano para a extração do orizanol. De fato, este comportamento pode ser explicado pela polaridade relativamente alta da molécula de orizanol (consistindo de alcoóis triterpênicos e fitoesteróis esterificados com ácido ferúlico), onde a polaridade do solvente pode afetar significativamente a extração do orizanol do farelo de arroz (Xu e Godber, 2000). Estruturas de três componentes do orizanol são mostradas na Figura 5.3.

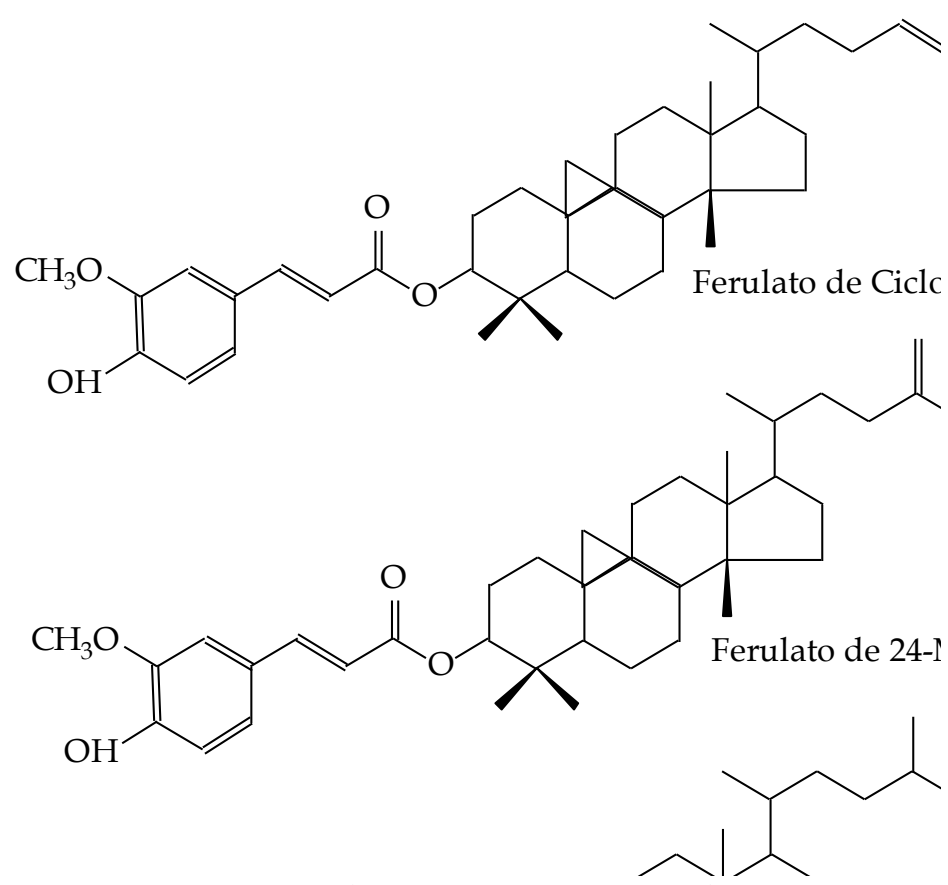

Figura 5.3 - Estruturas químicas de três componentes do gama-orizanol. 
$\mathrm{Na}$ Tabela 5.3 pode-se verificar que foram obtidos extratos contendo de 1527 a $4164 \mathrm{mg}$ de orizanol/kg de farelo de arroz, que corresponde a valores de 12,2 a 33,3 $\%$ do total de orizanol disponível, em um estágio de equilíbrio. Com base neste resultado, pode-se inferir que a total transferência do orizanol, do farelo para a fase extrato, pode ser controlada e maximizada pelo número de contatos sucessivos com o solvente.

Na Figura 5.2 (b), o comportamento dos tocóis é mostrado como função do conteúdo de água no solvente e da temperatura, mantendo-se os valores das variáveis razão solvente: sólido e velocidade de agitação nos níveis codificados como zero. Pode-se observar que a extração deste composto nutracêutico é favorecida pelo aumento da hidratação do solvente e da temperatura de extração.

Zigoneanu et al. (2008) observaram que isopropanol, a $40{ }^{\circ} \mathrm{C}$ com razão solvente: sólido de 3: 1, apresenta-se mais eficiente que o hexano na extração de vitamina E (tocoferóis e tocotrienóis) do farelo de arroz. Os autores obtiveram $87 \mathrm{mg}$ de vitamina $\mathrm{E} / \mathrm{kg}$ de farelo de arroz para isopropanol e $53 \mathrm{mg}$ de vitamina $\mathrm{E} / \mathrm{kg}$ de farelo de arroz para hexano. No presente trabalho, valores de 123 a $271 \mathrm{mg}$ de tocóis/kg de farelo de arroz foram obtidos usando-se etanol como solvente.

De fato, as Figuras 5.2, (a) e (b), mostram que orizanol e tocóis comportam-se de maneiras diferentes no processo de extração. É observada uma maior transferência de tocóis, da matriz sólida para o solvente, em relação à transferência de orizanol. Esta diferença pode ser atribuída a diferenças estruturais entre estas duas classes de moléculas. Os tocóis são menos hidrofóbicos que o gama-orizanol (Abidi et al., 2002); de fato, eles são compostos por moléculas pequenas que contém cadeias insaturadas na série de tocotrienóis e um menor número de substituições metila, quando comparadas às moléculas que compõem a mistura orizanol (Batista et al., 2009).

As estruturas dos tocoferóis e tocotrienóis (tocóis) são mostradas na Figura 5.4 . 
<smiles>[R1]c1c([R])c2c(c([R])c1O)CC[C@@](C)(CCCC(C)CCCCC)O2</smiles>

Tocoferol

$\mathrm{R}_{1}$

$\mathrm{R}_{1} \quad \mathrm{R}_{2} \quad \mathrm{R}_{3}$

$\begin{array}{lccc}\alpha & \text { Metil } & \text { Metil } & \text { Metil } \\ \beta & \text { Metil } & \text { Hidrogênio } & \text { Metil } \\ \gamma & \text { Hidrogênio } & \text { Metil } & \text { Metil } \\ \delta & \text { Hidrogênio } & \text { Hidrogênio } & \text { Metil }\end{array}$

Figura 5.4 - Estrutura química dos tocóis.

Monsoor e Proctor (2005) estudaram a aplicação de água deionizada como extratante de óleo de farelo de arroz em temperaturas de 20 a $60{ }^{\circ} \mathrm{C}$. Os autores observaram que a extração de tocotrienóis $(19-27 \%)$ e tocoferóis $(10-17 \%)$ foi maior que a extração de orizanol $(8-9 \%)$. Estes resultados corroboram os comentários prévios.

Em adição ao estudo da influência das variáveis de processo no rendimento e extração de compostos nutracêuticos, foi também realizado estudo para investigar a influência do solvente biorenovável na composição em ácidos graxos dos óleos extraídos.

De fato, existe um consenso entre os cientistas que a ingestão de gordura influencia fortemente o risco de doenças cardiovasculares, tais como doenças cardíacas coronarianas. No entanto, a composição qualitativa das gorduras ingeridas na dieta desempenha um importante papel na modificação deste risco (Deckere e Korver, 1996).

De acordo com a Organização Mundial da Saúde (OMS, 2010), o consumo de ácidos graxos saturados, principalmente os ácidos mirístico e palmítico, está 
diretamente relacionado ao risco de doenças cardiovasculares. Estes ácidos graxos, com 12-16 carbonos têm um grande efeito no aumento do nível da lipoproteína de baixa densidade (LDL) no plasma sanguíneo. Por outro lado, a OMS recomenda que as dietas devem prover quantidades adequadas de ácidos graxos poliinsaturados e, também, ácido oléico.

Neste contexto, pode-se inferir que o perfil de ácidos graxos no óleo de farelo de arroz apresenta um bom balanço em termos da razão entre ácidos graxos insaturados e saturados e, também, em termos da razão entre ácido linoléico e ácido palmítico e entre oléico e linoléico (Tabela 5.2).

Para se avaliar o efeito das variáveis independentes sobre a composição em ácidos graxos dos óleos extraídos em cada condição experimental, os extratos provenientes de cada tratamento foram submetidos à análise de ésteres metílicos de ácidos graxos (GC-FAME), e os dados foram analisados estatisticamente utilizando a análise de variância (ANOVA) e o teste de Tukey (software SAS®, versão 9.2).

A Tabela 5.6 apresenta os valores médios das massas molares, índices de iodo calculados e as razões mássicas entre ácidos graxos insaturados e saturados, ácidos linoléico e palmítico e ácidos oléico e linoléico.

Com base na análise estatística apresentada na Tabela 5.6, pode-se observar que não existem diferenças estatisticamente significativas entre as composições dos óleos obtidos segundo os experimentos planejados, óleo obtido via metodologia proposta por Bligh e Dyer (1959) e composição de óleo de farelo de arroz comercial, extraído com hexano (Firestone, 1999).

De fato, os óleos extraídos com etanol apresentaram composição típica de óleo de farelo de arroz (Oryza sativa) (Firestone, 1999) sem nenhuma mudança significativa na composição. De maneira geral, o processo de extração utilizando etanol como solvente permite a obtenção de óleo de farelo de arroz com alto valor para a razão entre ácidos graxos insaturados e saturados (acima de 4,0:1), alto valor para a razão entre ácidos linoléico e palmítico (acima de 2,7:1) além de valor de razão mássica entre o ácidos linoléico e oléico próximo a 1. 
Tabela 5.6 - Propriedades químicas dos extratos.

\begin{tabular}{cccccc}
\hline Exp $^{\mathrm{a}}$ & MM $\left(\mathbf{g} \cdot \mathbf{m o l}^{-1}\right)$ & $\mathbf{I V}$ & Insaturados $/$ Saturados & Linoléico / Palmítico & Oléico / Linoléico \\
\hline 1 & $276,3 \pm 0,1^{\mathrm{abc}}$ & $103,8 \pm 0,2^{\mathrm{abc}}$ & $3,57 \pm 0,03^{\mathrm{abcdef}}$ & $1,94 \pm 0,02^{\mathrm{abc}}$ & $0,97 \pm 0,00^{\mathrm{abc}}$ \\
2 & $276,2 \pm 0,3^{\mathrm{bc}}$ & $103,1 \pm 0,2^{\mathrm{abc}}$ & $3,49 \pm 0,02^{\mathrm{abcdefg}}$ & $1,90 \pm 0,01^{\mathrm{abc}}$ & $0,98 \pm 0,00^{\mathrm{abc}}$ \\
3 & $275,7 \pm 0,0^{\mathrm{bc}}$ & $103,3 \pm 0,2^{\mathrm{abc}}$ & $3,34 \pm 0,00^{\mathrm{bcdefg}}$ & $1,80 \pm 0,01^{\mathrm{bc}}$ & $0,95 \pm 0,00^{\mathrm{abcd}}$ \\
4 & $276,1 \pm 0,3^{\mathrm{bc}}$ & $103,3 \pm 0,2^{\mathrm{abc}}$ & $3,46 \pm 0,03^{\mathrm{abcdefg}}$ & $1,90 \pm 0,02^{\mathrm{abc}}$ & $0,97 \pm 0,00^{\mathrm{abc}}$ \\
5 & $276,2 \pm 0,2^{\mathrm{abc}}$ & $102,3 \pm 0,1^{\mathrm{bc}}$ & $3,35 \pm 0,04^{\mathrm{bcdefg}}$ & $1,84 \pm 0,02^{\mathrm{abc}}$ & $0,96 \pm 0,00^{\mathrm{abc}}$ \\
6 & $276,2 \pm 0,3^{\mathrm{bc}}$ & $103,0 \pm 0,2^{\mathrm{abc}}$ & $3,44 \pm 0,01^{\mathrm{abcdefg}}$ & $1,88 \pm 0,01^{\mathrm{abc}}$ & $0,96 \pm 0,01^{\mathrm{abc}}$ \\
7 & $275,8 \pm 0,6^{\mathrm{bc}}$ & $101,4 \pm 0,4^{\mathrm{bc}}$ & $3,20 \pm 0,03^{\text {defg }}$ & $1,77 \pm 0,04^{\mathrm{c}}$ & $0,99 \pm 0,01^{\mathrm{abc}}$ \\
8 & $275,7 \pm 0,5^{\mathrm{bc}}$ & $100,6 \pm 0,4^{\mathrm{bc}}$ & $3,07 \pm 0,00^{\mathrm{fg}}$ & $1,75 \pm 0,01^{\mathrm{c}}$ & $1,01 \pm 0,00^{\mathrm{abc}}$ \\
9 & $275,9 \pm 0,0^{\mathrm{bc}}$ & $103,6 \pm 0,9^{\mathrm{abc}}$ & $3,42 \pm 0,04^{\mathrm{bcdefg}}$ & $1,84 \pm 0,07^{\mathrm{abc}}$ & $0,94 \pm 0,03^{\mathrm{abcd}}$ \\
10 & $276,1 \pm 0,1^{\mathrm{bc}}$ & $105,9 \pm 0,6^{\mathrm{abc}}$ & $3,55 \pm 0,05^{\mathrm{abcdef}}$ & $1,98 \pm 0,00^{\mathrm{abc}}$ & $0,85 \pm 0,02^{\mathrm{cdef}}$ \\
11 & $276,1 \pm 0,8^{\mathrm{bc}}$ & $95,1 \pm 3,9^{\mathrm{cd}}$ & $3,13 \pm 0,19^{\mathrm{efg}}$ & $1,57 \pm 0,07^{\mathrm{c}}$ & $1,07 \pm 0,04^{\mathrm{ab}}$ \\
12 & $276,5 \pm 1,9^{\mathrm{abc}}$ & $110,8 \pm 13,7^{\mathrm{ab}}$ & $3,95 \pm 1,13^{\mathrm{ab}}$ & $2,65 \pm 1,34^{\mathrm{a}}$ & $0,71 \pm 0,24^{\mathrm{ef}}$ \\
13 & $278,8 \pm 3,1^{\mathrm{a}}$ & $99,1 \pm 8,9^{\mathrm{c}}$ & $3,90 \pm 0,12^{\mathrm{abcd}}$ & $2,02 \pm 0,17^{\mathrm{abc}}$ & $0,78 \pm 0,06^{\mathrm{def}}$ \\
14 & $276,4 \pm 0,1^{\mathrm{abc}}$ & $104,6 \pm 0,1^{\mathrm{abc}}$ & $3,66 \pm 0,02^{\mathrm{abcdef}}$ & $1,93 \pm 0,00^{\mathrm{abc}}$ & $0,93 \pm 0,00^{\mathrm{bcd}}$ \\
15 & $275,8 \pm 0,1^{\mathrm{bc}}$ & $105,6 \pm 0,8^{\mathrm{abc}}$ & $3,47 \pm 0,14^{\mathrm{abcdefg}}$ & $1,92 \pm 0,05^{\mathrm{abc}}$ & $0,89 \pm 0,01^{\mathrm{cd}}$
\end{tabular}




\section{Tabela 5.6 (continuação)}

\begin{tabular}{|c|c|c|c|c|c|}
\hline $\operatorname{Exp}^{a}$ & $\mathrm{MM}\left(\mathrm{g} \cdot \mathrm{mol}^{-1}\right)$ & IV & Insaturados / Saturados & Linoléico / Palmítico & Oléico / Linoléico \\
\hline $18^{\mathrm{b}}$ & n.d. & n.d. & n.d. & n.d. & n.d. \\
\hline 19 & $274,4 \pm 0,6^{\mathrm{c}}$ & $96,0 \pm 5,0^{\mathrm{cd}}$ & $2,79 \pm 0,38^{\mathrm{g}}$ & $1,54 \pm 0,16^{\mathrm{c}}$ & $0,91 \pm 0,04^{\mathrm{bcd}}$ \\
\hline 20 & $276,6 \pm 0,2^{\mathrm{abc}}$ & $102,0 \pm 0,2^{b c}$ & $3,43 \pm 0,00^{\text {abcdefg }}$ & $1,86 \pm 0,01^{\mathrm{abc}}$ & $0,94 \pm 0,00^{\mathrm{abcd}}$ \\
\hline $21^{\mathrm{b}}$ & n.d. & n.d. & n.d. & n.d. & n.d. \\
\hline 22 & $276,1 \pm 0,2^{b c}$ & $105,1 \pm 0,1^{\mathrm{abc}}$ & $3,69 \pm 0,03^{\text {abcdef }}$ & $2,03 \pm 0,04^{\mathrm{abc}}$ & $0,96 \pm 0,01^{\mathrm{abc}}$ \\
\hline 23 & $277,4 \pm 0,7^{\mathrm{ab}}$ & $95,5 \pm 1,8^{\text {cd }}$ & $3,45 \pm 0,10^{\text {abcdefg }}$ & $1,59 \pm 0,05^{\mathrm{c}}$ & $1,07 \pm 0,06^{\mathrm{ab}}$ \\
\hline $24^{\mathrm{b}}$ & n.d. & n.d. & n.d. & n.d. & n.d. \\
\hline 25 & $276,0 \pm 0,3^{b c}$ & $102,5 \pm 0,6^{b c}$ & $3,23 \pm 0,03^{\text {cdefg }}$ & $1,79 \pm 0,03^{b c}$ & $0,88 \pm 0,02^{\text {cde }}$ \\
\hline 26 & $276,1 \pm 0,7^{\mathrm{bc}}$ & $100,3 \pm 1,6^{\mathrm{bc}}$ & $3,16 \pm 0,02^{\operatorname{defg}}$ & $1,74 \pm 0,05^{\mathrm{c}}$ & $0,95 \pm 0,03^{\mathrm{abcd}}$ \\
\hline 27 & $276,0 \pm 0,1^{b c}$ & $101,4 \pm 0,9^{b c}$ & $3,29 \pm 0,10^{\text {bcdefg }}$ & $1,77 \pm 0,02^{\mathrm{c}}$ & $0,90 \pm 0,01^{\mathrm{bcd}}$ \\
\hline 28 & $275,9 \pm 0,2^{\mathrm{bc}}$ & $103,2 \pm 0,6^{\mathrm{abc}}$ & $3,28 \pm 0,04^{\text {bcdefg }}$ & $1,85 \pm 0,02^{\mathrm{abc}}$ & $0,90 \pm 0,01^{\mathrm{bcd}}$ \\
\hline 29 & $276,6 \pm 0,4^{\mathrm{abc}}$ & $114,4 \pm 0,3^{\mathrm{a}}$ & $4,01 \pm 0,01^{\mathrm{ab}}$ & $2,64 \pm 0,02^{\mathrm{ab}}$ & $0,68 \pm 0,01^{\mathrm{f}}$ \\
\hline Bligh-Dyer ${ }^{c}$ & $277,8 \pm 0,7^{\mathrm{abc}}$ & $104,1 \pm 0,7^{\mathrm{abc}}$ & $3,70 \pm 0,48^{\text {abcdefg }}$ & $2,20 \pm 0,06^{\mathrm{abc}}$ & $1,02 \pm 0,10^{\mathrm{abcd}}$ \\
\hline Literatura ${ }^{c}$ & $274,9 \pm 0,9^{\mathrm{bc}}$ & $86,8 \pm 3,5^{\mathrm{d}}$ & $3,30 \pm 0,04^{\text {bcdefg }}$ & $2,14 \pm 0,01^{\mathrm{abc}}$ & $0,93 \pm 0,01^{\mathrm{bcd}}$ \\
\hline
\end{tabular}

Valores médios \pm desvio padrão. Médias na mesma coluna com diferentes sobrescritos são significativamente diferentes (p < 0,05). ${ }^{a}$ Experimentos 1 a 29 da Tabela 5.3. ${ }^{\mathrm{b}}$ Resultados não disponíveis para os experimentos 18,21 e $24 .{ }^{\mathrm{c}}$ Dados da Tabela 5.2. 


\subsection{Conclusões}

Neste capítulo, através do delineamento experimental e da análise por superfície de resposta, foi possível a obtenção de modelos polinomiais quadráticos que podem ser utilizados para prever o rendimento da extração em termos de óleo de farelo de arroz e compostos nutracêuticos, gama-orizanol e tocóis, considerando etanol como solvente.

Dentro das condições operacionais investigadas, o ponto ótimo de extração foi obtido utilizando-se $6 \%$ de água no solvente, $82{ }^{\circ} \mathrm{C}, 4$ partes de solvente para 1 parte de farelo de arroz e 137,5 rpm, sendo possível a obtenção de 20,05 g de óleo/100 g de farelo de arroz (ou 99,9\% de todo o óleo disponível).

O nível de compostos nutracêuticos presente no óleo extraído pode ser controlado através da seleção do tipo de solvente e da temperatura do processo, sendo possível obter valores de 123 a $271 \mathrm{mg}$ de tocóis/kg de farelo de arroz e 1527 a $4164 \mathrm{mg}$ de orizanol/kg de farelo de arroz. Os resultados obtidos mostram que é possível obter óleo de farelo de arroz enriquecido com compostos nutracêuticos utilizando-se o solvente biorenovável.

Em adição, os resultados referentes ao perfil químico dos extratos indicam que o óleo extraído com etanol apresenta composição típica de óleo de farelo de arroz (Oryza sativa) independentemente das condições experimentais utilizadas. 


\title{
CATÍtULO 6
}

\section{EQUILÍBRIO LÍQUIDO-LÍQUIDO DE} SISTEMAS COMPOSTOS POR ÓLEO VEGETAL E SOLVENTES AlCoÓlicos:

\author{
APlicaÇão na Extração e
}

DESACIDIFICAÇÃO DE ÓLEO DE

FARELO DE ARROZ 


\subsection{Considerações Iniciais}

Nesta segunda fase do trabalho foi realizado estudo via simulação computacional do processo de extração de óleo de farelo de arroz. Este estudo permitiu a estimativa do número de estágios teóricos necessários para a extração do óleo da matriz sólida utilizando extrator contínuo operando em contracorrente.

Foram considerados os seguintes cenários: quatro tipos de solventes - hexano, etanol absoluto e etanol hidratado (com 6 ou 10\% de água, em massa), três diferentes valores de razão alimentação: solvente (F:S) - 0,8, 1,0 e 1,2, dois diferentes valores de temperatura - 50 e $80^{\circ} \mathrm{C}$ e um valor de recuperação do óleo de farelo de arroz fixado em $97 \%$.

Em relação às simulações utilizando etanol, os modelos estatísticos sugeridos nos capítulos 3 e 4 desta tese foram utilizados para estimar o índice de retenção e o teor de água na fase extrato para as temperaturas de processo de 50,0 e $80,0{ }^{\circ} \mathrm{C}$, respectivamente. Para o hexano foram consideradas informações disponíveis na literatura e somente uma temperatura de processo foi investigada, $50^{\circ} \mathrm{C}$.

Neste capítulo são apresentados, também, dados de equilíbrio líquido-líquido para sistemas compostos por óleo de farelo de arroz degomado e solvente alcoólico. Os parâmetros de interação do modelo UNIQUAC foram ajustados aos dados experimentais tornando possível não só a simulação de extratores líquido-líquido dedicados à desacidificação de óleos vegetais, mas também a predição das composições das fases, rica em óleo e rica em solvente, geradas a partir do resfriamento da corrente de extrato proveniente de extratores sólidolíquido quando etanol é utilizado como solvente.

Esta etapa do estudo do processo de extração possibilitou a submissão de um artigo em periódico internacional (Oliveira, Garavazo e Rodrigues, Journal of Food Enginering, 2011), além de um trabalho completo em evento internacional (1) e 2 resumos em eventos nacionais.

\subsection{Resultados e Discussão}

\subsubsection{Dados experimentais e modelagem termodinâmica do equilíbrio líquido-líquido}

A composição em ácidos graxos do óleo de farelo de arroz, utilizado para determinação dos dados de equilíbrio líquido-líquido é apresentada na Tabela 6.1.

A partir desta composição em ácidos graxos, a composição do óleo em triacilgliceróis pode ser estimada de acordo com o procedimento sugerido por Antoniosi Filho et al. (1995) (Tabela 6.2).

Na Tabela 6.2, os triacilgliceróis considerados como componentes do óleo de farelo de arroz foram aqueles de maior concentração entre todos os possíveis isômeros (com número 
igual de carbonos e de duplas ligações na molécula). Desta forma, para o ajuste dos parâmetros de interação do modelo termodinâmico, o óleo vegetal foi tratado como um triacilglicerol simples com massa molar média igual aquela estimada a partir da composição do óleo em triacilgliceróis (Tabela 6.2).

Tabela 6.1 - Composição em ácidos graxos do óleo de farelo de arroz (OFA).

\begin{tabular}{|c|c|c|c|c|c|}
\hline \multicolumn{3}{|c|}{ Ácido Graxo } & \multirow{2}{*}{$\begin{array}{c}\text { Massa } \\
\text { Molar } \\
\left(\mathbf{g} \cdot \mathbf{m o l}^{-1}\right)\end{array}$} & \multicolumn{2}{|c|}{ Composição } \\
\hline Símbolo & Nome IUPAC & $C x: y^{a}$ & & Molar (\%) & $\begin{array}{c}\text { Massa } \\
(\%)\end{array}$ \\
\hline $\mathrm{M}$ & tetradecanoico & $14: 0$ & 228,38 & 2,54 & 2,10 \\
\hline $\mathrm{P}$ & hexadecanoico & $16: 0$ & 256,43 & 20,38 & 18,94 \\
\hline $\mathrm{S}$ & octadecanoico & 18:0 & 284,49 & 1,67 & 1,72 \\
\hline $\mathrm{O}$ & cis-octadec-9-enoico & $18: 1$ & 282,47 & 36,49 & 37,36 \\
\hline $\mathrm{Li}$ & cis,cis-octadeca-9,12-dienoico & $18: 2$ & 280,45 & 35,10 & 35,68 \\
\hline Le & $\begin{array}{c}\text { all-cis-octadeca-9,12,15- } \\
\text { trienoico }\end{array}$ & $18: 3$ & 278,44 & 2,00 & 2,02 \\
\hline A & eicosanoico & 20:0 & 312,54 & 0,51 & 0,58 \\
\hline $\mathrm{Ga}$ & cis-11-eicosenoico & $20: 1$ & 310,52 & 0,36 & 0,40 \\
\hline $\mathrm{Be}$ & docosanoico & $22: 0$ & 340,59 & 0,42 & 0,52 \\
\hline & cis,cis-docosa-13, 16-dienoico & $22: 2$ & 336,56 & 0,22 & 0,27 \\
\hline $\mathrm{Lg}$ & tetracosanoico & $24: 0$ & 368,65 & 0,30 & 0,41 \\
\hline
\end{tabular}

${ }^{a} \mathrm{Cx}: \mathrm{y}, \mathrm{x}=$ número de carbonos e y=número de duplas ligações nas moléculas de ácidos graxos. 
Tabela 6.2 - Provável composição em triacilgliceróis (TAG) do óleo de farelo de arroz degomado.

\begin{tabular}{|c|c|c|c|}
\hline \multicolumn{2}{|c|}{ Triacilglicerol } & \multirow{2}{*}{ Massa Molar $\left(\mathrm{g} \cdot \mathrm{mol}^{-1}\right)$} & \multirow{2}{*}{ Composição (\% molar) } \\
\hline Símbolo $^{\mathrm{a}}$ & Notação $^{b}$ & & \\
\hline MOP & $48: 1$ & 805,32 & 1,19 \\
\hline MLiP & $48: 2$ & 803,30 & 1,15 \\
\hline POP & $50: 1$ & 833,37 & 4,90 \\
\hline PLiP & $50: 2$ & 831,35 & 5,89 \\
\hline MOLi & $50: 3$ & 829,34 & 2,53 \\
\hline LiLiM & $50: 4$ & 827,32 & 1,22 \\
\hline POS & $52: 1$ & 861,42 & 0,86 \\
\hline OOP & $52: 2$ & 859,40 & 10,22 \\
\hline PLiO & $52: 3$ & 857,39 & 18,23 \\
\hline LiLiP & $52: 4$ & 855,37 & 9,80 \\
\hline PLiLe & $52: 5$ & 853,37 & 1,00 \\
\hline OOS & $54: 2$ & 887,46 & 1,24 \\
\hline OOO & $54: 3$ & 885,44 & 6,30 \\
\hline OOLi & $54: 4$ & 883,43 & 14,19 \\
\hline $\mathrm{LiLiO}$ & $54: 5$ & 881,41 & 13,75 \\
\hline LiLiLi & $54: 6$ & 879,43 & 5,62 \\
\hline LiLiLe & $54: 7$ & 877,38 & 0,75 \\
\hline OLiA & $56: 3$ & 913,52 & 0,62 \\
\hline LiLiA & $56: 4$ & 911,50 & 0,51 \\
\hline
\end{tabular}

${ }^{a}$ Símbolos dos ácidos graxos estão especificados na Tabela 1. Grupos com composição total de triacilgliceróis (TAG) menor que $0,5 \%$ foram ignorados. ${ }^{\mathrm{b}}$ Esta notação considera somente o número de carbonos, exceto carbonos do glicerol, e o número de duplas ligações na molécula de triacilglicerol.

Os resultados mostrados nas Tabelas 6.1 e 6.2 permitiram calcular a massa molar média dos ácidos graxos livres naturalmente presentes no óleo degomado e, também, a massa molar média do óleo de farelo de arroz. De fato, foi assumido que a acidez livre apresenta a mesma composição em ácidos graxos do óleo degomado, sendo o conteúdo de acidez livre no óleo igual a 4,90 \pm 0,02\% em massa (acidez calculada de acordo com item 2.1.2.5.2, Capítulo 2). Os valores das massas molares médias e dos parâmetros de área e volume (calculados de acordo com a equação 2.36, Capítulo 2) são apresentados na Tabela 6.3. 
Tabela 6.3 - Massas molares médias e parâmetros estruturais de área $\left(q_{\mathrm{i}}^{\prime}\right)$ e volume $\left(r_{\mathbf{i}}^{\prime}\right)$.

\begin{tabular}{|c|c|c|c|}
\hline Composto & Massa Molar $\left(\mathrm{g} \cdot \mathrm{mol}^{-1}\right)$ & $r_{i}^{\prime b}$ & $q_{\mathrm{i}}^{\prime c}$ \\
\hline Óleo de farelo de arroz degomado (1) & $863,52^{a}$ & 0,04447 & 0,03606 \\
\hline Ácidos graxos livres (2) & 275,92 & 0,04504 & 0,03707 \\
\hline Etanol (3) & 46,07 & 0,05591 & 0,05618 \\
\hline Água (4) & 18,02 & 0,05107 & 0,07771 \\
\hline
\end{tabular}

${ }^{a}$ Massa molar média do óleo calculada através da composição em TAG estimada (Tabela 6.2). ${ }^{b}$ Parâmetro estrutural de volume (Magnussen et al., 1981). ${ }^{~}$ Parâmetro estrutural de área (Magnussen et al., 1981).

O óleo de farelo de arroz degomado utilizado no estudo apresentou 1,78 $\pm 0,01 \% \mathrm{em}$ massa de gama-orizanol e $0,11 \pm 0,01 \%$ em massa de tocóis (tocoferóis e tocotrienóis). As concentrações dos compostos minoritários no óleo degomado e nas fases, alcoólica e oleosa, foram determinadas de acordo com os itens 2.1.2.5.7 e 2.1.2.5.8 (Capítulo 2), respectivamente. A partição dos compostos minoritários entre as duas fases líquidas foi determinada a fim de se calcular os coeficientes de distribuição, sendo o orizanol designado como pseudo-componente 5 e os tocóis como pseudo-componente 6 . Vale ressaltar que os compostos minoritários não foram considerados no ajuste termodinâmico sendo, portanto, incorporados a fração de óleo (componente 1).

A Tabela 6.4 apresenta as composições, reportadas como porcentagens mássicas, das fases alcoólica e oleosa para os sistemas pseudo-quaternários estudados.

A Figura 6.1 apresenta os dados experimentais bem como as linhas de amarração, ou tie lines, calculadas pelo modelo UNIQUAC para os sistemas compostos por óleo de farelo de arroz degomado e solvente (i.e., etanol com 6,34 $\pm 0,03$ e 18,87 $\pm 0,07 \%$ em massa de água) a diferentes temperaturas $\left(10,0 \pm 0,1\right.$ e $\left.35,0 \pm 0,1{ }^{\circ} \mathrm{C}\right)$. Os diagramas de equilíbrio foram graficados em coordenadas retangulares e, para possibilitar a representação de um sistema pseudo-quaternário neste tipo de coordenada, etanol e água foram assumidos como solvente misto. Nestas figuras, a composição em fração mássica do óleo vegetal, em ambas as fases, pode ser obtida por diferença. 
Tabela 6.4 - Dados de equilíbrio líquido-líquido para sistemas contendo óleo de farelo de arroz degomado (1) + ácidos graxos livres (2) + etanol (3) + água (4), em diferentes temperaturas.

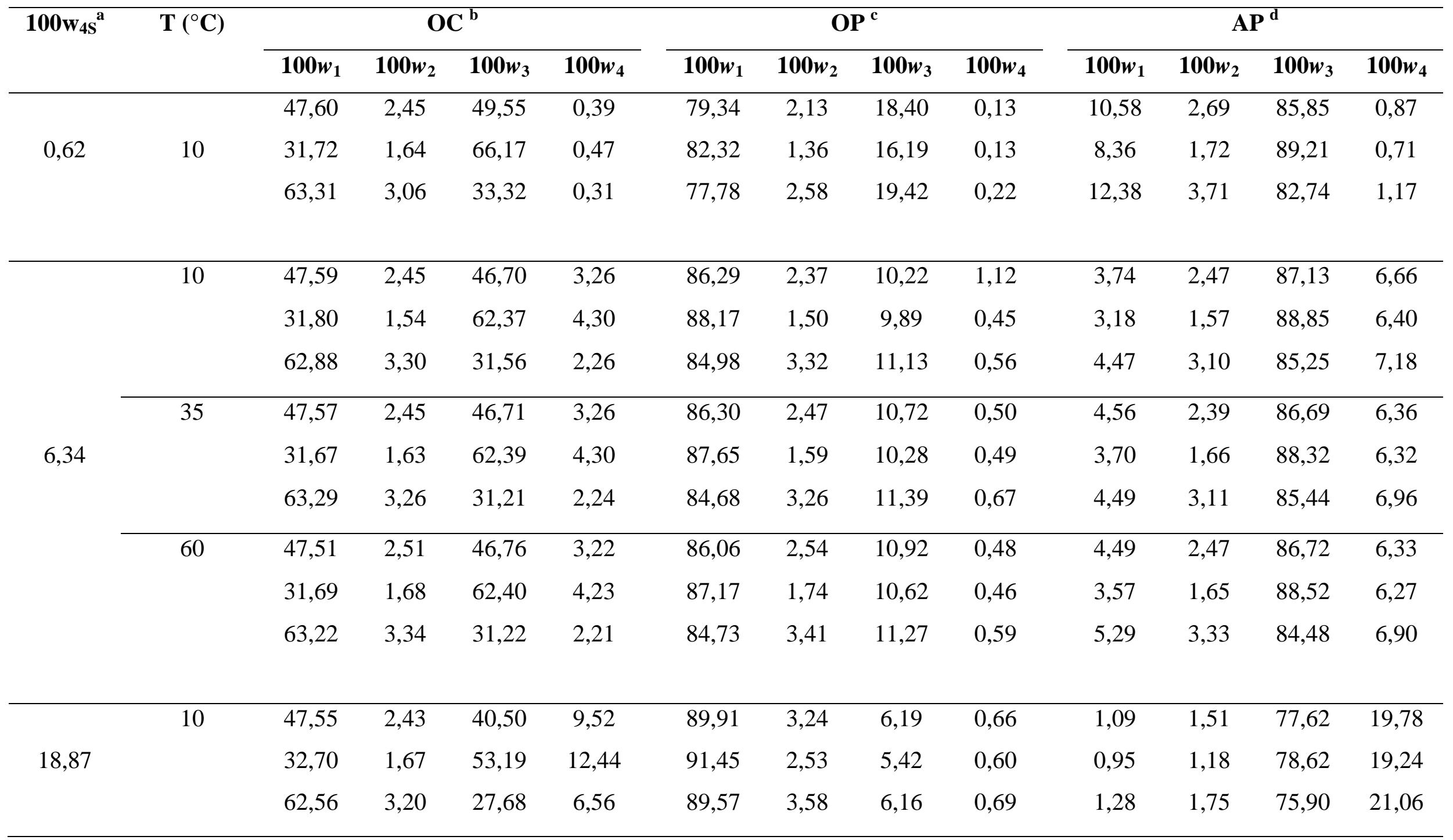


Capítulo 6 - Extração Sólido-líquido e "Flash" Líquido-líquido

\begin{tabular}{|c|c|c|c|c|c|c|c|c|c|c|c|c|c|}
\hline \multicolumn{14}{|c|}{ Tabela 6.4 (continuação) } \\
\hline \multirow[t]{2}{*}{$100 w_{45} s^{a}$} & \multirow[t]{2}{*}{$\mathbf{T}\left({ }^{\circ} \mathbf{C}\right)$} & \multicolumn{4}{|c|}{$\mathrm{OC}^{\mathrm{b}}$} & \multicolumn{4}{|c|}{$\mathbf{O P}^{\mathrm{c}}$} & \multicolumn{4}{|c|}{$\mathbf{A} \mathbf{P}^{\mathbf{d}}$} \\
\hline & & $100 w_{1}$ & $100 w_{2}$ & $100 w_{3}$ & $100 w_{4}$ & $100 w_{1}$ & $100 w_{2}$ & $100 w_{3}$ & $100 w_{4}$ & $100 w_{1}$ & $100 w_{2}$ & $100 w_{3}$ & $100 w_{4}$ \\
\hline \multirow{4}{*}{18,87} & & 31,43 & 1,52 & 54,35 & 12,70 & 90,69 & 2,34 & 6,36 & 0,62 & 1,00 & 1,08 & 79,36 & 18,56 \\
\hline & & 63,54 & 3,07 & 26,98 & 6,40 & 89,06 & 3,63 & 6,61 & 0,71 & 1,45 & 1,65 & 76,48 & 20,41 \\
\hline & & 31,81 & 1,54 & 54,02 & 12,63 & 90,21 & 2,29 & 5,94 & 1,57 & 1,13 & 1,17 & 79,27 & 18,43 \\
\hline & & 63,50 & 3,07 & 27,02 & 6,42 & 88,99 & 3,66 & 6,49 & 0,86 & 1,71 & 1,71 & 76,91 & 19,67 \\
\hline \multirow{3}{*}{28,29} & 35 & 47,57 & 2,30 & 36,32 & 13,81 & 90,54 & 3,57 & 5,25 & 0,64 & 0,51 & 0,77 & 68,99 & 29,73 \\
\hline & & 31,50 & 1,97 & 47,25 & 19,29 & 90,14 & 3,85 & 5,32 & 0,69 & 0,49 & 0,71 & 72,64 & 26,17 \\
\hline & & 63,46 & 3,19 & 23,85 & 9,49 & 90,47 & 4,22 & 4,70 & 0,60 & 0,41 & 0,88 & 67,14 & 31,57 \\
\hline
\end{tabular}

${ }^{\mathrm{a}} 100 \mathrm{w}_{4 \mathrm{~S}}=$ água no solvente (porcentagem em massa). ${ }^{\mathrm{b}} \mathrm{OC}=$ ponto de mistura. ${ }^{\mathrm{c}} \mathrm{OP}=$ fase oleosa. ${ }^{\mathrm{d}} \mathrm{AP}=$ fase alcoólica. Óleo de farelo de arroz degomado (1), Ácidos graxos livres (2), Etanol (3) e Água (4). 

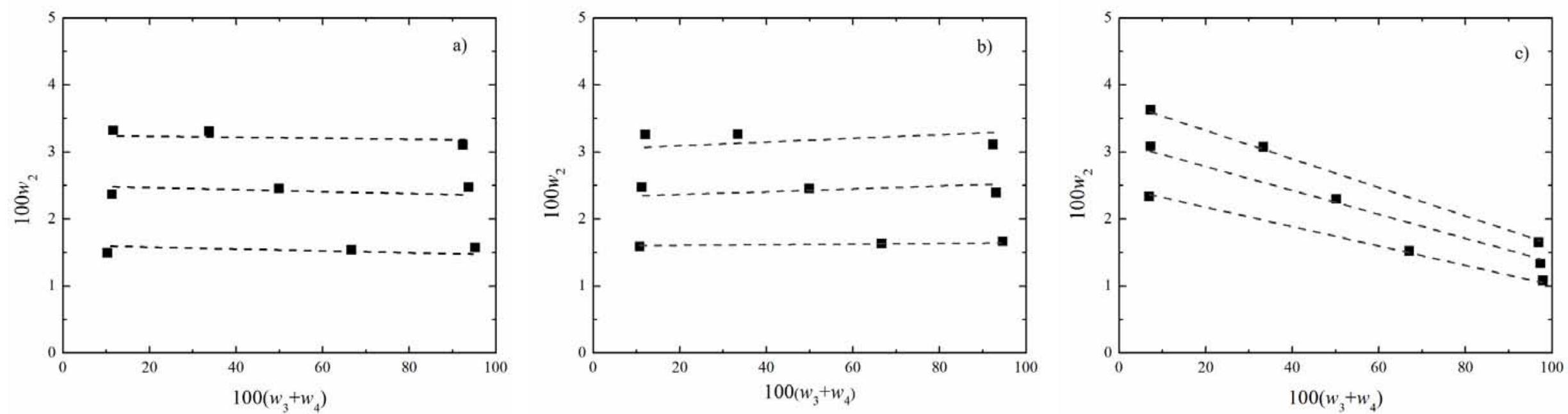

Figura 6.1 - Sistemas compostos por óleo de farelo de arroz degomado (1) + ácidos graxos livres (2) + solvente [etanol (3) + água (4)]: ( experimental; (- - ) calculado pelo modelo UNIQUAC. a) 6,34 $\pm 0,03 \%$ de água em massa, a 10,0 $\left.\pm 0,1{ }^{\circ} \mathrm{C} ; \mathrm{b}\right) 6,34 \pm 0,03 \%$ de água em massa, a 35,0 $\pm 0,1^{\circ} \mathrm{C} ;$ c) $18,87 \pm 0,07 \%$ de água em massa, a $35,0 \pm 0,1^{\circ} \mathrm{C}$. 
A análise da Figura 6.1, (a) e (b), indica que a solubilidade mútua dos compostos do sistema foi pouco afetada pela temperatura. De fato, para o sistema com etanol com $6 \%$ de água como solvente, o aumento da temperatura parece não influenciar a solubilidade do óleo na fase alcoólica e também a solubilidade do solvente na fase oleosa. Esta observação está de acordo com trabalhos prévios publicados por Chiyoda et al. (2010) e Cuevas et al. (2009) em estudos relacionados ao equilíbrio de fases de sistemas contendo óleo de soja e de semente de girassol, respectivamente.

Nestes trabalhos os autores mencionaram que os óleos vegetais, misturas de variedades de compostos apolares, podem ser solvatados via hidratação hidrofóbica em solventes com alto teor de água. Para sistemas contendo solventes hidratados, a hidratação hidrofóbica do óleo pode estar associada com o pequeno efeito da temperatura na solubilidade do óleo na fase alcoólica.

Por outro lado, a Figura 6.1 (b) e (c) mostra que a adição de água ao solvente provoca um aumento do tamanho da região bifásica, decorrente, provavelmente da redução da solubilidade entre óleo e solvente. Em outras palavras, a proporção de solvente na fase oleosa e a proporção de óleo na fase alcoólica decrescem com a adição de água ao solvente, facilitando a subsequente remoção para recuperação do solvente.

Os resultados mostrados na Figura 6.1 indicam que a adição de água reduz a capacidade do solvente de extrair ácidos graxos livres. De fato, este efeito é sugerido pela inversão das tie lines (linhas de amarração) para os sistemas com solventes com alto conteúdo de água. Em adição, pode-se inferir que o modelo termodinâmico utilizado nesta fase do estudo possibilitou uma adequada descrição da composição das fases alcoólica e oleosa dos sistemas graxos estudados.

A Figura 6.2 apresenta o coeficiente de distribuição dos ácidos graxos livres, como função da temperatura, para três diferentes valores de razão mássica óleo: solvente $(2: 1,1: 1$ e $1: 2$, respectivamente). O coeficiente de distribuição é definido como o fator de separação dos ácidos graxos livres entre as duas fases líquidas, oleosa e alcoólica, na condição de equilíbrio. Neste trabalho o coeficiente de distribuição dos ácidos graxos livres $\left(k_{2}\right)$ foi calculado utilizando as frações mássicas, de acordo com a equação 6.1, levando em conta as diferenças entre as massas molares dos compostos do sistema (Capítulo 2, item 2.1.2.10).

$k_{i}=\frac{w_{i}^{A P}}{w_{i}^{O P}}$

Onde $w$ é a fração mássica, $i$ é o componente graxo e os sobrescritos $O P$ e $A P$ representam as fases oleosa e alcoólica, respectivamente. 


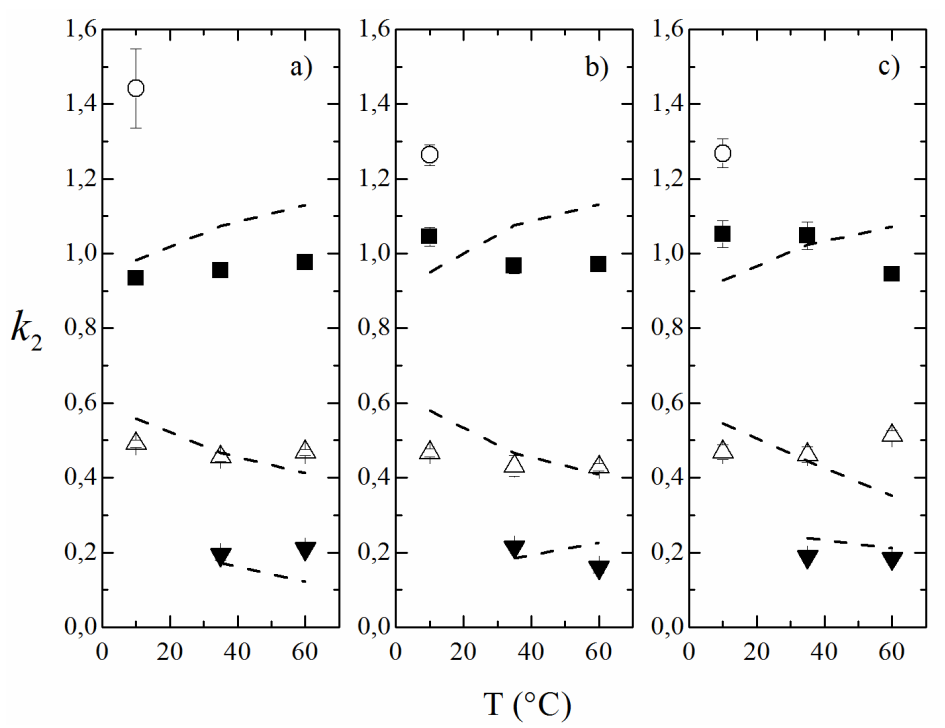

Figura 6.2 - Coeficientes de distribuição dos ácidos graxos livres $\left(k_{2}\right)$ como função da temperatura, para diferentes razões óleo: solvente: a) 2:1; b) 1:1; c) 1:2. Exp: (०) $100 w_{4 S}=0,62 \pm 0,07 \%$; (a) $100 w_{4 S}=6,34 \pm 0,03 \%$; (4) $100 w_{4 S}=18,87 \pm$ $0,07 \%$; ( V) $100 w_{4 S}=28,29 \pm 0,05 \%$; (- - ) calculado pelo modelo UNIQUAC.

Como mostrado na Figura 6.2, o aumento do conteúdo de água no solvente reduz a capacidade deste em extrair os ácidos graxos livres (veja como os valores de $k_{2}$ diminuem à medida que o teor de água no solvente aumenta). Em adição, pode-se observar que a temperatura não influencia a distribuição dos ácidos graxos livres entre as duas fases líquidas, além disso, nota-se que o coeficiente de partição não é dependente das frações mássicas de óleo e solvente nos sistemas graxos. Estas observações estão de acordo com estudo reportado por Reipert et al. (2011). Neste trabalho os autores concluem que a partição dos ácidos graxos livres entre as fases oleosa e alcoólica aumenta à medida que o comprimento da cadeia carbônica da molécula de AGL diminui, porém a distribuição pouco depende da temperatura. Na Figura 6.2 também pode ser observado que o modelo UNIQUAC descreve razoavelmente a partição dos ácidos graxos livres entre as fases alcoólica e oleosa.

Neste trabalho, a influência da temperatura e do teor de hidratação do solvente foi também avaliada sobre os coeficientes de distribuição dos compostos nutracêuticos naturalmente presentes no óleo de farelo de arroz, gama-orizanol e tocóis (tocoferóis e tocotrienóis). As Figuras 6.3 e 6.4, respectivamente, apresentam os coeficientes de distribuição do gama-orizanol e dos tocóis (calculados de acordo com a equação 6.1), como função da temperatura, para três diferentes valores de razão mássica óleo: solvente $(2: 1,1: 1$ e $1: 2$, respectivamente). 

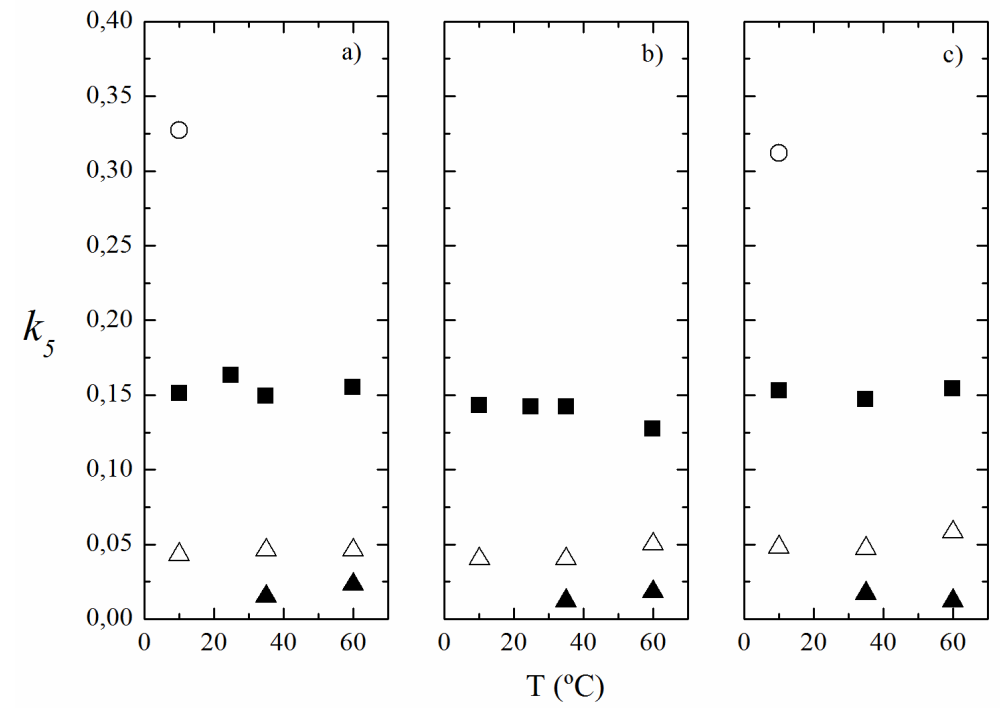

Figura 6.3 - Coeficientes de distribuição do gama-orizanol $\left(k_{5}\right)$ como função da temperatura, para diferentes razões óleo: solvente: a) 2:1; b) 1:1; c) 1:2. Exp: (0) $100 w_{4 S}=0,62 \pm 0,07 \%$; (a) $100 w_{4 S}=6,34 \pm 0,03 \%$; (4) $100 w_{4 S}=18,87 \pm$ $0,07 \% ;(\nabla) 100 w_{4 S}=28,29 \pm 0,05 \%$.
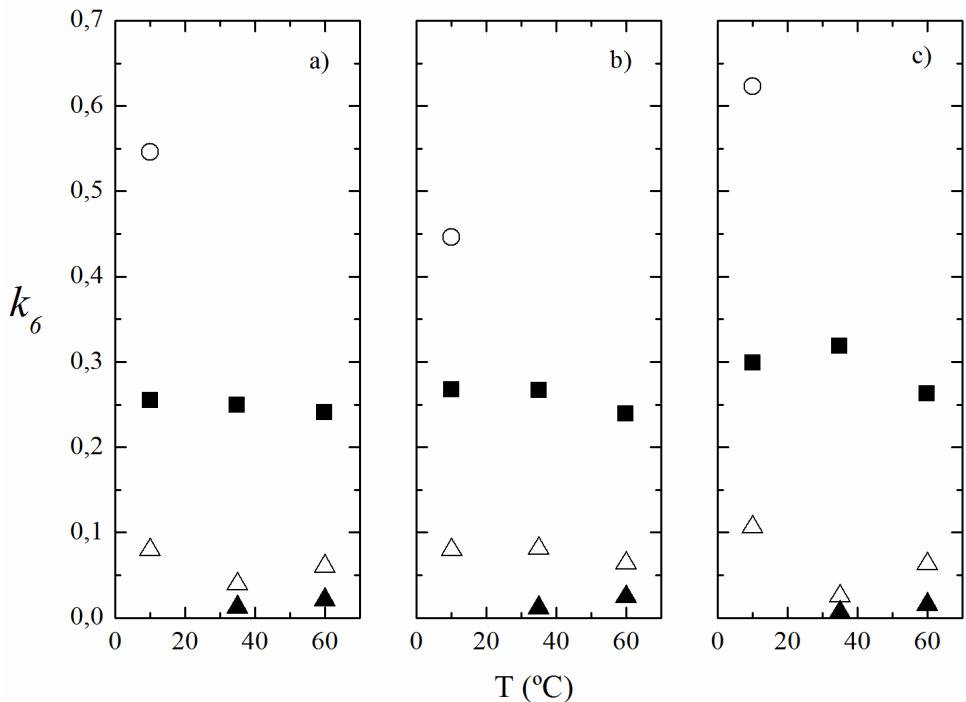

Figura 6.4 - Coeficientes de distribuição dos tocóis $\left(k_{6}\right)$ como função da temperatura, para diferentes razões óleo: solvente: a) 2:1; b) 1:1; c) 1:2. Exp: (०) $100 w_{4 S}=0,62 \pm$ $0,07 \%$; (口) $100 w_{4 S}=6,34 \pm 0,03 \%$; (4) $100 w_{4 S}=18,87 \pm 0,07 \%$; ( V) $100 w_{4 S}$ $=28,29 \pm 0,05 \%$.

Com base nos dados experimentais de partição dos compostos nutracêuticos apresentados nas Figuras 6.3 e 6.4, pode-se observar que a extração dos compostos antioxidantes é fortemente influenciada pelo teor de água no solvente. O aumento do nível de hidratação do solvente etanólico diminui a extração de ambos os tipos de compostos minoritários. 
Em a relação à temperatura, pode-se afirmar que não existe variação significativa de $k_{5}$ e $k_{6}$ com o acréscimo da temperatura em uma mesma razão de óleo e solvente e mesmo grau de hidratação do mesmo.

Os dados apresentados nas Figuras 6.3 e 6.4 mostram também que, apesar dos compostos nutracêuticos apresentarem comportamento similar frente às variações de temperatura e teor de água no solvente, de maneira geral os coeficientes de distribuição dos tocóis são maiores que os apresentados pelo gama-orizanol.

Este comportamento pode ser atribuído a diferenças estruturais entre os tipos de moléculas, como previamente observado no Capítulo 5. Os tocóis apresentam menor hidrofobicidade que o gama-orizanol devido serem compostos por moléculas menores (aproximadamente $400 \mathrm{~g} / \mathrm{gmol}$ ) que aquelas que compõem o gama-orizanol (aproximadamente $600 \mathrm{~g} / \mathrm{gmol}$ ). Além disso, as moléculas de tocóis apresentam um grande número de insaturações, principalmente os tocotrienóis, e um menor número de substituições por radicais metil que o gama-orizanol (Rodrigues et al., 2004; Abidi et al., 2002).

A Tabela 6.5 apresenta os parâmetros de interação ajustados para o modelo UNIQUAC. Os desvios entre as composições experimentais e calculadas pelo modelo, calculados de acordo com a equação 2.41 (Capítulo 2), são mostrados na Tabela 6.6.

É possível inferir que o modelo termodinâmico utilizado neste estudo possibilitou uma razoável descrição da solubilidade do solvente na fase oleosa bem como do óleo na fase rica em solvente (fase alcoólica) (vide Figura 6.1). Estes resultados estão de acordo com os baixos valores obtidos para os desvios (Tabela 6.6).

Tabela 6.5 - Parâmetros para o modelo UNIQUAC.

\begin{tabular}{ccccc}
\hline par ij $^{\mathbf{a}}$ & $A_{0, i j}(\mathbf{K})$ & $A_{0, j i}(\mathbf{K})$ & $A_{1, i j}$ & $A_{1, j i}$ \\
\hline 12 & 71,96 & $-436,21$ & $-604,07$ & 190,98 \\
13 & $-54,85$ & $-66,86$ & 301,48 & 3,96 \\
14 & $-361,58$ & 207,99 & 949,04 & $-296,04$ \\
23 & $-1759,30$ & $-843,05$ & 1930,38 & $-286,07$ \\
24 & $-2464,30$ & $-28398,0$ & 2905,21 & 47889,23 \\
34 & $-2107,90$ & $-400,44$ & 2658,26 & 8,28 \\
\hline
\end{tabular}

${ }^{a}$ Óleo de farelo de arroz degomado (1), Ácidos graxos livres (2), Etanol (3) e Água (4). ${ }^{b} A_{0, i j}$ e $A_{0, j i}$ são os parâmetros de energia expressos em Kelvin. 
Tabela 6.6 - Desvios médios nas composições das fases.

\begin{tabular}{|c|c|c|}
\hline Temperatura $\left({ }^{\circ} \mathrm{C}\right)$ & $100 w_{4 S}{ }^{a}$ & $\Delta w(\%)^{b}$ \\
\hline & 0,62 & 0,73 \\
\hline \multirow[t]{3}{*}{10} & 6,34 & 0,53 \\
\hline & 18,87 & 0,22 \\
\hline & 6,34 & 0,22 \\
\hline \multirow[t]{3}{*}{35} & 18,87 & 0,16 \\
\hline & 28,29 & 0,29 \\
\hline & 6,34 & 0,54 \\
\hline \multirow[t]{2}{*}{60} & 18,87 & 0,35 \\
\hline & 28,29 & 0,26 \\
\hline Desvio global da correlação & & 0,35 \\
\hline
\end{tabular}

${ }^{\mathrm{a}} 100 \mathrm{w}_{4 \mathrm{~S}}=$ porcentagem de água no solvente. ${ }^{\mathrm{b}}$ Desvio calculado de acordo com equação 2.41 (Capítulo 2).

\subsubsection{Simulação do Extrator Sólido-líquido}

A Figura 6.5 apresenta o número de estágios teóricos necessários para extrair o óleo de farelo de arroz da matriz sólida considerando-se uma recuperação de 97\%. Nesta figura estão apresentados resultados referentes aos solventes estudados, hexano, etanol absoluto e etanol hidratado (com 6 ou $10 \%$ de água em massa), nas temperaturas de 50 e $80{ }^{\circ} \mathrm{C}$. É importante enfatizar que os cálculos referentes ao solvente hexano foram realizados somente na temperatura de processo de $50{ }^{\circ} \mathrm{C}$.

Os cálculos realizados permitem inferir que o número de estágios necessários para a realização das extrações com etanol é maior que o número de estágios requerido para as extrações com hexano, independentemente da razão farelo: solvente. Em adição, o número necessário de estágios aumenta à medida que a hidratação do solvente etanólico aumenta e, por outro lado, o aumento da temperatura de extração resulta em uma diminuição do número de estágios teóricos. 


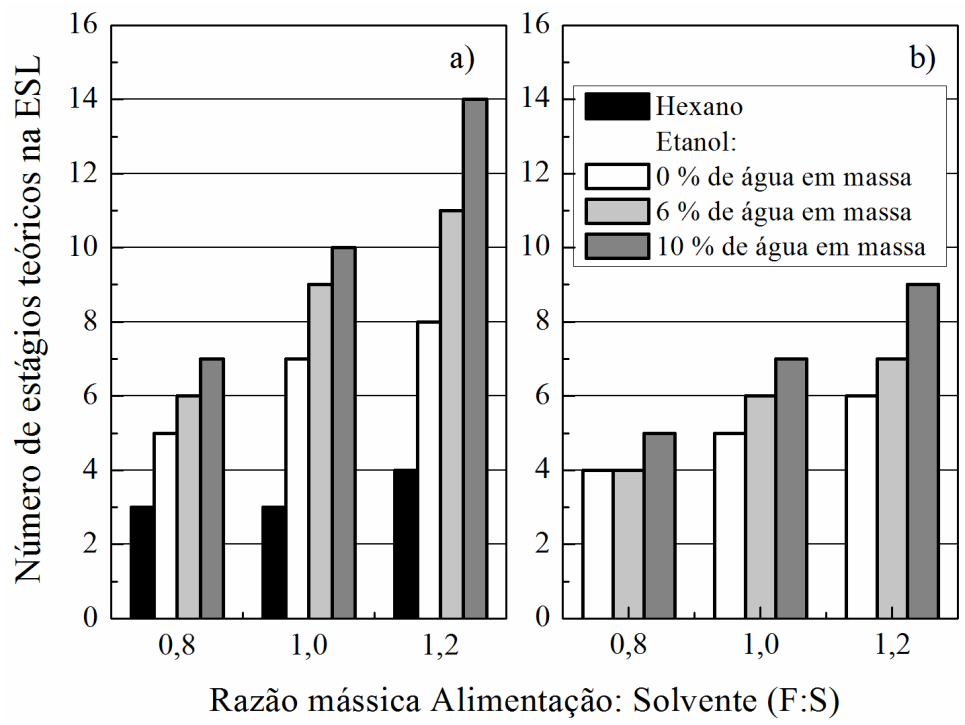

Figura 6.5 - Número de estágios teóricos na ESL como função da razão mássica entre alimentação (farelo de arroz) e solvente ( $F: S)$ e temperatura de processo: a) 50 ${ }^{\circ} \mathrm{C}$; b) $80^{\circ} \mathrm{C}$.

Os efeitos da hidratação do solvente etanólico e temperatura estão relacionados não somente com a extensão da solubilidade do óleo no solvente, mas também com a influência destas variáveis sobre o índice de retenção. Como comentado nos capítulos anteriores, este índice é uma variável de engenharia que afeta fortemente o número de estágios requeridos para a realização da extração (Kocatas and Cornell, 1954; Rittner, 1984; Wisniak et al., 1987).

Nos capítulos 3 e 4 desta tese pôde-se observar que o índice de retenção aumenta com o aumento da hidratação do solvente, sendo que a temperatura apresenta influência estatisticamente significativa sobre esta variável somente quando solventes com baixo teor de água são utilizados. Nestes casos, o índice de retenção diminui à medida que temperaturas mais elevadas (acima de $60^{\circ} \mathrm{C}$ ) são utilizadas.

Desta forma, pode-se considerar como vantajosa a utilização de temperaturas de processo mais elevadas (Figura 6.5 (b)), sendo que nesta condição o número de estágios teóricos diminui devido ao impacto da variável temperatura sobre o índice de retenção e solubilidade.

A Tabela 6.7 apresenta as composições das fases extrato $\left(\mathrm{E}_{1}\right)$ provenientes de cada extração sólido-líquido bem como as vazões mássicas de ambas as correntes de saída, extrato $\left(E_{1}\right)$ e rafinado $\left(R_{n}\right)$. Como comentado anteriormente, a fase extrato proveniente de cada processo de extração foi submetida ao resfriamento o que ocasionou a geração de duas fases líquidas, uma fase rica em óleo e outra rica em solvente. 
Tabela 6.7 - Vazões mássicas e composições das correntes de saída do extrator sólido-líquido.

\begin{tabular}{|c|c|c|c|c|c|c|c|}
\hline \multirow{2}{*}{$\begin{array}{l}\text { Temperatura } \\
\left({ }^{\circ} \mathrm{C}\right)\end{array}$} & \multirow[t]{2}{*}{ Solvente } & \multirow{2}{*}{$\begin{array}{l}\text { Razão mássica } \\
\text { alimentação: } \\
\text { solvente (F:S) }\end{array}$} & \multirow{2}{*}{$\begin{array}{l}\text { Vazão mássica } \\
\text { da fase rafinado } \\
\left(\mathbf{k g} \cdot \mathbf{h}^{-1}\right)\end{array}$} & \multirow{2}{*}{$\begin{array}{l}\text { Vazão mássica } \\
\text { da fase extrato } \\
\left(\mathrm{kg} \cdot \mathrm{h}^{-1}\right)\end{array}$} & \multicolumn{3}{|c|}{ Composição da fase extrato $^{a}$} \\
\hline & & & & & $100 w_{1}$ & $100 w_{3}$ & $100 w_{4}$ \\
\hline \multirow[t]{3}{*}{50} & hexano & 0,8 & 1112,00 & 1138,00 & 17,05 & 82,95 & - \\
\hline & & 1,0 & 1112,00 & 888,00 & 21,85 & 78,15 & - \\
\hline & & 1,2 & 1112,00 & 721,33 & 26,89 & 73,11 & - \\
\hline \multirow[t]{9}{*}{50} & etanol & 0,8 & 1408,64 & 841,36 & 23,06 & 74,37 & 2,57 \\
\hline & absoluto & 1,0 & 1408,64 & 591,36 & 32,81 & 64,62 & 2,57 \\
\hline & & 1,2 & 1408,64 & 424,69 & 45,68 & 51,75 & 2,57 \\
\hline & etanol com 6 & 0,8 & 1488,16 & 761,84 & 25,46 & 66,88 & 7,65 \\
\hline & \% de água & 1,0 & 1488,16 & 511,84 & 37,90 & 54,45 & 7,65 \\
\hline & em massa & 1,2 & 1488,16 & 345,18 & 56,20 & 36,15 & 7,65 \\
\hline & etanol com & 0,8 & 1544,00 & 706,00 & 27,48 & 61,32 & 11,20 \\
\hline & $10 \%$ de água & 1,0 & 1544,00 & 456,00 & 42,54 & 46,26 & 11,20 \\
\hline & em massa & 1,2 & 1544,00 & 289,33 & 67,05 & 21,75 & 11,20 \\
\hline \multirow[t]{9}{*}{80} & etanol & 0,8 & 1297,35 & 952,65 & 20,36 & 77,67 & 1,97 \\
\hline & absoluto & 1,0 & 1297,35 & 702,65 & 27,61 & 70,42 & 1,97 \\
\hline & & 1,2 & 1297,35 & 535,98 & 36,20 & 61,84 & 1,97 \\
\hline & etanol com 6 & 0,8 & 1351,75 & 898,25 & 21,60 & 71,53 & 6,87 \\
\hline & \% de água & 1,0 & 1351,75 & 648,25 & 29,93 & 63,20 & 6,87 \\
\hline & em massa & 1,2 & 1351,75 & 481,58 & 40,28 & 52,84 & 6,87 \\
\hline & etanol com & 0,8 & 1418,25 & 831,76 & 23,32 & 66,14 & 10,53 \\
\hline & 10 \% de água & 1,0 & 1418,25 & 581,76 & 33,35 & 56,12 & 10,53 \\
\hline & em massa & 1,2 & 1418,25 & 415,09 & 46,74 & 42,73 & 10,53 \\
\hline
\end{tabular}

${ }^{a}$ Óleo de farelo de arroz (1), Etanol (3) e Água (4). 
A Figura 6.6 (a), (b) e (c) apresenta a solubilidade do solvente (etanol e água) na fase rica em óleo $\left(100 w_{3+4}^{O P}\right)$, e a Figura 6.6 (d), (e) e (f) mostra a solubilidade do óleo na fase rica em solvente $\left(100 w_{1}^{A P}\right)$, respectivamente, como função da temperatura de resfriamento. Os dados apresentados nesta figura correspondem às operações de extração sólido-líquido realizadas a $80^{\circ} \mathrm{C}$.
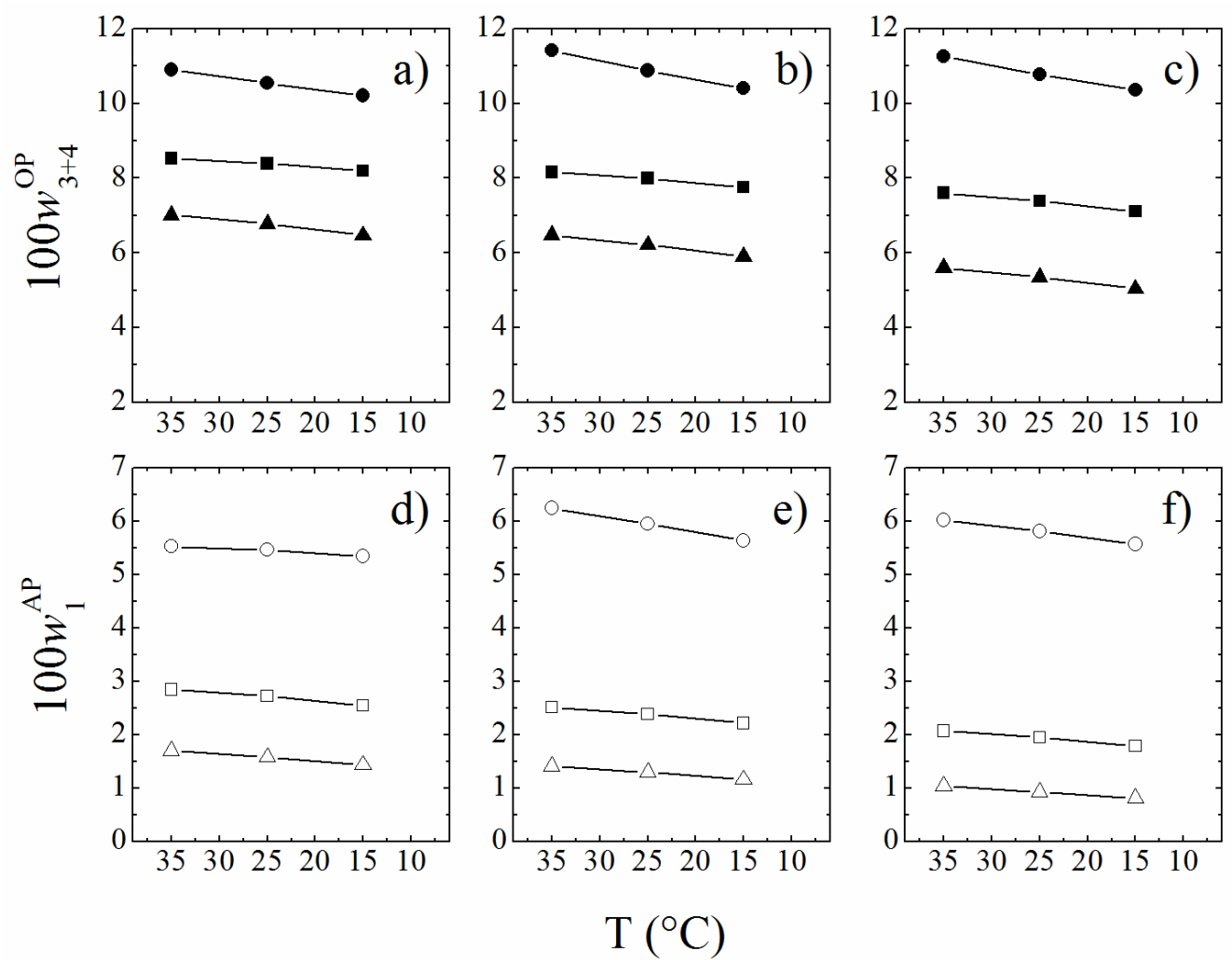

Figura 6.6 - Solubilidade do solvente na fase rica em óleo (100 $\left.w_{3+4}^{O P}\right):(-\bullet-) 100 w_{4 S}=0 \%$;

(-E) $100 w_{4 S}=6 \%$; (- $\left.\Delta-\right) 100 w_{4 S}=10 \%$; e solubilidade de óleo na fase rica em solvente (100 $\left.w_{1}^{A P}\right):(-0-) 100 w_{4 S}=0 \% ;(-\square-) 100 w_{4 S}=6 \% ;(-\Delta-) 100 w_{4 S}=$ $10 \%$, como função da temperatura de resfriamento para diferentes valores de $F: S$. (a) $e(d) F: S=0,8 ;(b) e(e) F: S=1,0 ;(c) e(f) F: S=1,2$.

De acordo com os resultados apresentados na Figura 6.6, o aumento do teor de água no solvente acarreta em uma diminuição da solubilidade mútua entre óleo e solvente, para todos os níveis de temperatura de resfriamento estudados. Nos níveis de temperatura de resfriamento mais baixos, pode-se observar uma diminuição da quantidade de solvente solubilizada na fase rica em óleo bem como uma diminuição da quantidade de óleo solubilizada na fase solvente.

As proporções de óleo e solvente dissolvidas nas respectivas fases também diminuem com o aumento dos valores da razão mássica alimentação: solvente alimentada ao extrator. 
Estes resultados mostram que a submissão da corrente $\mathrm{E}_{1}$ a um procedimento flash líquido-líquido possibilita a obtenção de uma fase rica em óleo a qual apresentará de 5 a 11\% de solvente, dependendo do tipo de solvente e temperatura de resfriamento. Em relação à fase rica em solvente, os teores de óleo dissolvido podem variar de 0,5 a $6 \%$. De fato, o procedimento de resfriamento poderá desonerar as etapas de dessolventização do óleo e recuperação do solvente.

Neste contexto, a Figura 6.7 apresenta a eficiência de recuperação do solvente após o resfriamento da corrente de processo de 50 a $25{ }^{\circ} \mathrm{C}$, Figura 6.7 (a), e de 80 a $25{ }^{\circ} \mathrm{C}$, Figura 6.7 (b), respectivamente. A eficiência de recuperação do solvente foi calculada de acordo com a equação 6.2 .

Eficiência de Recuperação $(\%)=100 \frac{w_{3+4}^{A P} \cdot M^{A P}}{w_{3+4}^{E_{1}} \cdot M^{E_{1}}}$

Onde $w$ é fração mássica, os subscritos 3 e 4 representam etanol e água, respectivamente, $\mathrm{M}$ é a vazão mássica $\left(\mathrm{kg} \cdot \mathrm{h}^{-1}\right)$ e os sobrescritos $E_{l}$ e $A P$ representam a fase extrato proveniente do extrator sólido-líquido e a fase rica em solvente proveniente do processo de resfriamento, respectivamente.

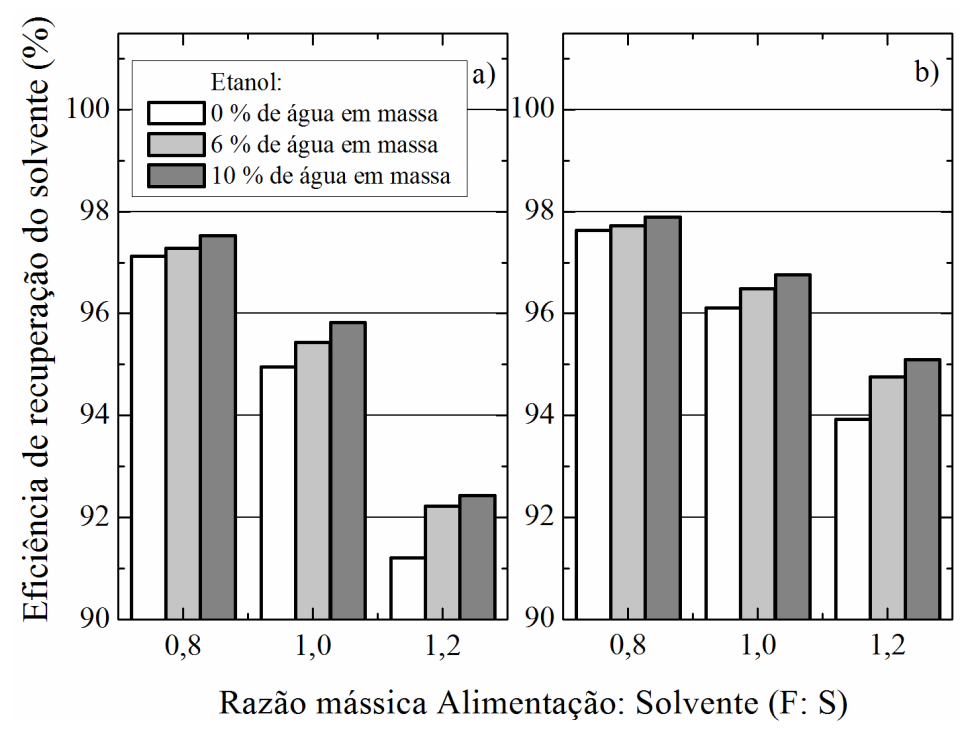

Figura 6.7 - Eficiência de recuperação do solvente (\%) como função da razão mássica alimentação: solvente $(F: S)$ e temperatura no processo de extração sólidolíquido: a) $50{ }^{\circ} \mathrm{C}$; b) $80{ }^{\circ} \mathrm{C}$.

Com relação à eficiência de recuperação do solvente, pode-se inferir que uma maior proporção de solvente em relação ao farelo de arroz, alimentados ao extrator sólido-líquido, leva ao aumento da eficiência de recuperação do solvente durante o processo de resfriamento. Em adição, processos de extração realizados a $80{ }^{\circ} \mathrm{C}$ além de permitirem a utilização de 
extratores com um número menor de estágios teóricos possibilitam, também, a obtenção de altos valores de eficiência na etapa de recuperação do solvente. Os dados apresentados na Figura 6.7 também indicam que a hidratação do solvente etanólico acarreta em uma maior eficiência de recuperação do solvente, sendo este efeito mais proeminente em situações onde maiores proporções de farelo de arroz são utilizadas em relação ao solvente.

\subsection{Conclusões}

Os resultados apresentados neste capítulo da tese contribuem para um melhor entendimento dos processos de obtenção de óleo de farelo de arroz, via extração com solvente, bem como do processo de desacidificação, ambos utilizando o solvente biorenovável, etanol. Através do conhecimento dos valores do coeficiente de distribuição dos ácidos graxos livres e dos compostos nutracêuticos, bem como da solubilidade mútua dos compostos em função da temperatura, é possível o projeto de tanques flash líquido-líquido e extratores líquido-líquido para recuperação do solvente e desacidificação do óleo, respectivamente.

As composições das fases, rica em solvente e rica em óleo, foram bem representadas através dos cálculos utilizando-se os parâmetros do modelo termodinâmico UNIQUAC, ajustados nesta fase do trabalho. Os valores calculados para o equilíbrio líquido-líquido apresentaram desvios médios menores que $0,73 \%$ quando comparados aos dados de equilíbrio determinados experimentalmente.

Os parâmetros de interação estimados neste trabalho são úteis para prever a composição das fases líquidas formadas a partir do resfriamento da corrente de extrato oriunda do extrator sólido-líquido. Foi observado que é possível recuperar o solvente com eficiência acima de $98 \%$ quando a corrente de extrato é resfriada de 80 a $25^{\circ} \mathrm{C}$.

Em relação ao processo de extração do óleo de farelo de arroz da matriz sólida utilizando o etanol como solvente, observou-se que o número de estágios teóricos para as extrações com etanol é sempre superior em relação ao número necessário quando se utiliza hexano como solvente. Além disso, o número de contatos sucessivos aumenta à medida que a hidratação do solvente etanólico aumenta. Por outro lado, o aumento da temperatura do processo de extração possibilita a obtenção de valores similares de recuperação de óleo (fixada em 97\% neste trabalho) utilizando-se um número menor de estágios teóricos no extrator sólido-líquido. 
CATÍtULO 7

\section{Conclusões Gerais}




\section{Conclusões Gerais}

A metodologia de superfície de resposta permitiu uma fácil visualização de como as variáveis independentes selecionadas - teor de água no solvente, temperatura, razão mássica sólido: solvente e velocidade de agitação - influenciam as diversas variáveis dependentes monitoradas - transferências de compostos lipídicos e água da matriz sólida para a fase extrato, viscosidade e densidade da fase extrato, índice de retenção de solução na fase sólida, entre outras. Os modelos gerados pela análise de superfície de resposta, referentes aos quatro tipos de planejamento de experimentos realizados, apresentaram baixos desvios relativos em relação aos dados experimentais.

Os resultados experimentais referentes à extração de óleo de farelo de arroz e de soja, em um estágio de equilíbrio, utilizando-se etanol com diferentes graus de hidratação como solvente (0 a 24\%, em massa) na faixa de temperatura de 40 a $90{ }^{\circ} \mathrm{C}$ mostram que, independentemente da matéria-prima, a extração de sólidos solúveis é fortemente influenciada pelo teor de água no solvente alcoólico. O aumento do teor de água no etanol suprime fortemente a extração de sólidos solúveis enquanto o aumento da temperatura somente favorece o aumento do nível de extração dos sólidos solúveis para menores teores de água no solvente.

Foi possível observar que a hidratação da fase solvente praticamente independe da temperatura, na faixa de trabalho considerada nesta tese $\left(40\right.$ a $\left.90{ }^{\circ} \mathrm{C}\right)$. De fato, observa-se que existe um equilíbrio entre a umidade do sólido e o nível de hidratação do solvente etanol.

Em relação ao índice de retenção, pode-se observar que esta variável é fortemente influenciada pelo nível de hidratação do solvente, independentemente da temperatura de trabalho. Por outro lado, o efeito da temperatura torna-se estatisticamente significativo somente para as extrações realizadas acima de $60{ }^{\circ} \mathrm{C}$. O tipo de conformação do sólido também afeta a quantidade de solução aderida ao sólido, sendo que os valores de índice de retenção para o pellet de farelo de arroz são 30 a 58\% menores que os obtidos para a soja em lâminas. Os modelos estatísticos obtidos para as respostas índice de retenção, densidade e viscosidade da fase extrato propiciaram o cálculo do índice de retenção modificado, através do qual foi possível observar que o índice de retenção aumenta com o aumento do valor da viscosidade da fase extrato. 
A análise termodinâmica do processo de extração alcoólica de óleos vegetais indicou que as mudanças de entalpia e entropia no processo de extração de óleo de soja diminuem à medida que o nível de hidratação do solvente aumenta. Em temperaturas acima de $80{ }^{\circ} \mathrm{C}$ foi possível a obtenção de valores negativos para a variação de energia livre para todos os tipos de solventes estudados. Estes resultados permitem inferir que o processo de extração usando etanol como solvente é possível e espontâneo, sendo favorecido pelo aumento da temperatura.

Em relação ao estudo do comportamento dos compostos nutracêuticos, gama-orizanol e tocóis, sob diferentes condições de processo, pode-se verificar que o nível de compostos nutracêuticos presente no óleo extraído pode ser controlado através da seleção do tipo de solvente e da temperatura do processo, sendo possível obter valores de 123 a $271 \mathrm{mg}$ de tocóis/kg de farelo de arroz e 1527 a $4164 \mathrm{mg}$ de orizanol/kg de farelo de arroz. Os resultados obtidos mostram que é possível obter óleo de farelo de arroz enriquecido com compostos nutracêuticos utilizando-se o solvente biorenovável.

Os resultados referentes ao perfil químico dos extratos indicam que o óleo extraído com etanol apresenta composição típica de óleo de farelo de arroz (Oryza sativa) independentemente das condições experimentais utilizadas. O processo de extração utilizando etanol como solvente permite a obtenção de óleo de farelo de arroz com alto valor para a razão entre ácidos graxos insaturados e saturados (acima de 4,0:1), alto valor para a razão entre ácidos linoléico e palmítico (acima de 2,7:1) além de valor de razão mássica entre o ácidos linoléico e oléico próximo a 1.

O equilíbrio líquido-líquido de sistemas graxos compostos por óleo de farelo de arroz degomado + ácidos graxos livres + etanol + água foi estudado na faixa de temperatura de $10 \mathrm{a}$ $60{ }^{\circ} \mathrm{C}$. Os dados experimentais obtidos apresentaram baixos desvios experimentais atestando a adequação da metodologia experimental adotada para obtenção das composições das fases alcoólica e oleosa. Os valores dos coeficientes de distribuição, grandezas calculadas a partir dos dados de concentração, apresentaram uma baixa dispersão, o que reforça a boa qualidade dos dados experimentais.

Os dados experimentais de equilíbrio de fases obtidos nesta tese foram correlacionados pelo modelo molecular UNIQUAC. Foram ajustados 24 parâmetros de interação entre binários, para 4 componentes, obtendo-se baixos desvios médios nas composições das fases (menores que $0,8 \%$ ). 
Os parâmetros de interação estimados neste trabalho são úteis para prever a composição das fases líquidas formadas a partir do resfriamento da corrente de extrato oriunda do extrator sólido-líquido. Foi observado que é possível recuperar o solvente com eficiência acima de $98 \%$ quando a corrente de extrato é resfriada de 80 a $25{ }^{\circ} \mathrm{C}$. Em adição, estes parâmetros também permitem a correta simulação de extratores líquido-líquido dedicados a desacidificação de óleo de farelo de arroz.

Em relação ao processo de extração do óleo de farelo de arroz da matriz sólida utilizando o etanol como solvente, observou-se que o número de estágios teóricos para as extrações com etanol é sempre superior em relação ao número necessário quando se utiliza hexano como solvente. Além disso, o número de contatos sucessivos aumenta à medida que a hidratação do solvente etanólico aumenta. Por outro lado, o aumento da temperatura do processo de extração possibilita a obtenção de valores similares de recuperação de óleo (fixada em 97\% neste trabalho) utilizando-se um número menor de estágios teóricos no extrator sólido-líquido.

De maneira geral, pode-se inferir que o nível ótimo de hidratação do solvente é cerca de $6 \%$, em massa, o que ocasiona bons valores para o rendimento de extração, em termos de óleo e compostos nutracêuticos e valores intermediários de índice de retenção. Esta condição possibilita, ainda, a realização do procedimento de extração em equipamentos de 4 a 7 estágios, na faixa de temperatura ótima ao redor de $80^{\circ} \mathrm{C}$. Em relação à etapa de recuperação do solvente, de 95 a $98 \%$ do etanol hidratado com $6 \%$ de água pode ser recuperado através de flash líquido-líquido quando o processo de resfriamento é conduzido de 80 a $25^{\circ} \mathrm{C}$.

Em adição, a escolha desta condição de operação também leva em conta a etapa de recuperação do solvente presente na fase extrato. A utilização de etanol com cerca de $6 \%$ de água como extratante possibilita a recuperação do solvente presente na fase alcoólica por destilação simples.

Os resultados apresentados nesta tese de livre docência contribuem para um melhor entendimento dos processos de obtenção de óleos vegetais, via extração com solvente, bem como do processo de desacidificação, ambos utilizando o solvente biorenovável, etanol. 


\section{CATÍtULO 8}

\section{DIRECIONAMENTO DA LINHA DE PESQUISA}




\section{Direcionamento da linha de pesquisa}

A seguir é sugerido, como direcionamento da linha de pesquisa "Extração alcoólica de óleos vegetais", o estudo dos seguintes tópicos:

$\checkmark$ Estudo da cinética de extração de óleos vegetais com monitoramento do total de compostos graxos extraídos, como função do tempo, bem como o monitoramento de compostos minoritários de interesse, tais como compostos antioxidantes e ácidos graxos livres;

$\checkmark$ Avaliação da influência das variáveis de processo na qualidade da fração protéica do farelo desengordurado obtido via extração com etanol;

$\checkmark$ Estudo a dependência do índice de retenção em relação às propriedades físicas das soluções óleo + solvente;

$\checkmark$ Realização do estudo experimental do processo de extração em equipamento contínuo multiestágios. 


\section{Referências Bibliográficas}

Abidi, S. L., Thiam, S. \& Warner, I. M. (2002). Elution behavior of unsaponifiable lipids with various capillary electrochromatographic stationary phases. Journal of Chromatography A, 949(1-2), 195-207.

Abraham, G., Hron, R.J. \& Koltun, S.P. (1988). Modeling the solvent extraction of oilseeds. Journal of the American Oil Chemists Society, 65(1), 129-135.

Abraham, G., Decossas, K. M., Hron, R. J. \& Kuk, M. S. (1991). Process engineering economic-evaluation of the ethanol extraction of cottonseed - preliminary-analysis. Journal of the American Oil Chemists Society, 68(6), 418-421.

Abraham, G., Hron, R. J., Kuk, M. S. \& Wan, P. J. (1993). Water accumulation in the Alcohol Extraction of Cottonseed. Journal of the American Oil Chemists Society, 70, 207-210.

Abrams, D. S. \& Prausnitz, J. M. (1975). Statistical thermodynamics of liquid mixtures: a new expression for the excess Gibbs energy of partly or completely miscible systems. AIChE Journal, 21, 116-128.

Almeida, R. L., Ravagnani, M. A. S. S., \& Modenes, A. N. (2010). Soybean oil extraction in belt extractors with miscella recirculation. Chemical Engineering and Processing, 49, 996-1005.

Amarasinghe, B. M. W. P. K., Kumarasiri, M. P. M. \& Gangodavilage, N. C. (2009). Effect of method of stabilization on aqueous extraction of rice bran oil. Food and Bioproducts Processing, 87, 108-114.

American Petroleum Institute (API). (1983). Neurotoxicity: n-Henane and hexane isomers. Washington: Medical Research Publications, 30-32846 e 30-32858..

Anderson, D. (2005). A Primer on Oils Processing Technology. In: F. Shahidi (editor), Bailey's Industrial Oil and Fat Products, (p 1-56). New Jersey: John Wiley and Sons.

Antoniassi, R., Esteves, W., Meirelles, A. J. A. (1998). Pretreatment of corn oil for physical refining. Journal of American Oil Chemists' Society, 75(10), 1411-1415.

Antoniosi Filho, N. R., Mendes, O. L., \& Lanças, F. M. (1995). Computer prediction of triacylglycerol composition of vegetable oils by HRGC. Chromatographia, 40(9-10), 557-562.

AOCS. (1998). Official methods and recommended practices of the American Oil Chemists' Society, Press, 3 ed., Champaign, v. 1-2.

Apelblat, A., Zaharoskin, T., Wisniak, J. \& Korngold, E. (1996). Extraction of oleic acid from soybean oil and jojoba oil - Phase diagrams. Journal of the American Oil Chemists' Society, 73(2), 239-244.

Arnold, L. K. \& Ppool, R. S. (1953). Effects of certain operating variables on the continuous solvent extraction of vegetable oils. Journal of the American Oil Chemists' Society, 30(12), 611-613.

Arnold, L. K. \& Choudhury, R. B. R. (1962). Ethanol extraction of soybean oil. Journal of the American Oil Chemists' Society, 39(8), 379.

Baker, E. C. \& Sullivan, D. A. (1983). Development of a pilot-plant process for the extraction of soy flakes with aqueous isopropyl-alcohol. Journal of the American Oil Chemists Society, 60(7), 1271-1277.

Batista, E., Monnerat, S., Kato, K., Stragevitch, L. \& Meirelles, A. J. A. (1999a). Liquid-liquid equilibrium for systems of canola oil, oleic acid and short-chain alcohols. Journal of Chemical and Engineering Data, 44(6), 1360-1364.

Batista, E., Monnerat, S., Stragevitch, L., Pina, C. G., Gonçalves, C. B. \& Meirelles, A. J. A. (1999b). Prediction of liquid-liquid equilibrium for systems of vegetable oils, fatty acids, and ethanol. Journal of Chemical and Engineering Data, 44(6), 1365-1369. 
Batista, E. A. C., Meirelles, A. J.A., Rodrigues, C. E. C. \& Gonçalves, C. B. (2009). Liquid-liquid extraction applied to the processing of vegetable oil, in: Meireles, A.J.A. (Ed.), Extracting bioactive compounds for food products. CRC Press, Florida, USA, pp. 219-267.

Beckel, A. C., Belter, P. A. \& Smith, A. K. (1946). Laboratory study of continuous vegetable oil extraction countercurrent extractor, rising-film evaporator, and oil stripper. Industrial and Engineering ChemistryAnalytical Edition, 18(1), 56-58.

Beckel, A. C., Belter, P. A. \& Smith, A. K. (1948a). The nondistillation alcohol extraction process for soybean oil. Journal of the American Oil Chemists' Society, 25(1), 10-11.

Beckel, A. C., Belter, P. A. \& Smith, A. K. (1948b). Solvent effects on the products of soybean oil extraction. Journal of the American Oil Chemists' Society, 25(1), 7-9.

Becker, W. (1978). Solvent extraction of soybeans. Journal of the American Oil Chemists' Society, 55, 754761.

Belda, R., Herraez, J. V. \& Diez, O. (2004). Rheological study and thermodynamic analysis of the binary system (water/ethanol): influence of concentration. Physics and Chemistry of Liquids, 42(5), 467-479.

Bhagya, S. \& Srinivas, H. (1992). Extraction of soybean (Glycine max.) with hexane-acetic acid: Effect on oil quality. Food Chemistry, 44, 123-125.

Bhosle, B. M. \& Subramanian, R. (2005). New approaches in deacidification of edible oils-a review. Journal of Food Engineering, 69, 481-94.

Bligh, E. G. \& Dyer, W. J. (1959). A rapid method of total lipid extraction and purification. Canadian Journal of Biochemistry and Physiology, 37, 911-917.

Box, G. E. P., Hunter, W. G. \& Hunter, J. S. (1978). Statistic for experimenters - an introduction to design, data analysis and model building. New York: John Wiley \& Sons.

Brasil. (2011a). Ministério do Desenvolvimento, Indústria e Comércio Exterior. http://www.mdic.gov.br/pdp/index.php/politica/setores/sistemaAgroindustrial/164. Acesso em 18 de setembro de 2011 .

Brasil. (2011b). Ministério da Agricultura, Pecuária e Abastecimento. http://www.agricultura.gov.br/vegetal/estatisticas. Acesso em 18 de setembro de 2011.

Brossard-González, C. O., Ferrari, R. A., Pighinellia, A. L. \& Park, K. J. (2010). Preliminary evaluation of anhydrous ethanol as a solvent in the oilseed extraction of Jatropha curcas L. Grasas y Aceites, 61(3), 295-302.

Bulley, N. R., Fattori, M., Meisen, A. \& Moyls, L. (1984). Supercritical fluid extraction of vegetable oil seeds. Journal of the American Oil Chemists' Society, 61(8), 1362-1365.

Canapi, E. C., Agustin, Y. T. V., Moro, E. A., Pedrosa Jr., E. \& Bendano, M. L. (2005). Coconut oil. In: F. Shahidi (editor), Bailey's Industrial Oil and Fat Products, (p. 123-147). New Jersey: John Wiley and Sons.

Carr, R. A. (1978). Refining and degumming systems for edible fats and oils. Journal of the American Oil Chemists' Society, 55, 765-771.

CEPEA. (2011a). PIB do agronegócio brasileiro - março de 2011. http://www.cepea.esalq.usp.br/pib/. Acesso em 31 de agosto de 2011.

CEPEA. (2011b). PIB do agronegócio brasileiro - abril de 2011. http://www.cepea.esalq.usp.br/pib/. Acesso em 31 de agosto de 2011.

Chien, J. T., Hoff, J. E., Lee, M. J., Lin, H. M., Chen, Y. J. \& Chen, L. F. (2002). Oil extraction of dried ground corn with ethanol. The Chemical Engineering Journal, 43, B103-B113. 
Chiyoda, C., Peixoto, E. C. D., Meirelles, A. J. A. \& Rodrigues, C. E. C. (2010). Liquid-liquid equilibria for systems composed of refined soybean oil, free fatty acids, ethanol, and water at different temperatures. Fluid Phase Equilibria, 299, 141-147.

Cho, S. Y., Kwon, T. W. \& Yoon, S. H. (1990). Selective removal of free fatty acids in oils using a microorganism. Journal of the American Oil Chemists' Society, 67, 558-60.

Christensen, P. L. (1983). Solvent extraction: Recent developments. Journal of the American Oil Chemists' Society, 60(2), 214-215.

Corso, M. P., Fagundes-Klen, M. R., Silva, E. A., Cardozo Filho, L., Santos, J. N., Freitas, L. S. \& Dariva, C. (2010). Extraction of sesame seed (Sesamun indicum L.) oil using compressed propane and supercritical carbon dioxide. Journal of Supercritical Fluids, 52(1), 56-61.

Coutinho, C. D., Chiu, M. C.; Basso, R. C., Ribeiro, A. P. B., Goncalves, L. A. G. \& Viotto, L. A. (2009). State of art of the application of membrane technology to vegetable oils: A review. Food Research International, 42(5-6), 536-550.

Cren, E. C. \& Meirelles, A. J. A. (2005). Adsorption isotherms for oleic acid removal from ethanol plus water solutions using the strong anion-exchange resin Amberlyst A26 OH. Journal of Chemical and Engineering Data, 50(5), 1529-1534.

Cren, E. C., Cardozo Filho, L., Silva, E. A. \& Meirelles, A. J. A. (2009). Breakthrough curves for oleic acid removal from ethanolic solutions using a strong anion exchange resin. Separation and Purification Technology, 69(1), 1-6.

Cren, E. C., Morelli, A. C., Sanches, T., Rodrigues, C. E. C. \& Meirelles, A. J. A. (2010). Adsorption isotherms for removal of linoleic acid from ethanolic solutions using the strong anion exchange resin Amberlyst A26 OH. Journal of Chemical and Engineering Data, 55(7), 2563-2566.

Cuevas, M. S., Rodrigues, C. E. C. \& Meirelles, A. J. A. (2009). Effect of solvent hydration and temperature in the deacidification process of sunflower oil using ethanol. Journal of Food Engineering, 95, 291-297.

Cuevas, M. S., Rodrigues, C. E. C., Gomes, G. B. \& Meirelles, A. J. A. (2010). Vegetable oils deacidification by solvent extraction: liquid-liquid equilibrium data for systems containing sunflower seed oil at $298.2 \mathrm{~K}$. Journal of Chemical and Engineering Data, 55, 3859-3862.

Cvengros, J. (1995). Physical refining of edible oils. Journal of the American Oil Chemists' Society, 72, 1193 1196.

Deckere, E. A. M. \& Korver, O. (1996). Minor constituents of rice bran oil as functional foods. Nutrition Reviews, 54(11), 120S-126S.

Do, L. D. \& Sabatini, D. A. (2010). Aqueous extended-surfactant based method for vegetable oil extraction: Proof of concept. Journal of the American Oil Chemists' Society, 87(10), 1211-1220.

Do, L. D. \& Sabatini, D. A. (2011). Pilot scale study of vegetable oil extraction by surfactant-assisted aqueous extraction process. Separation Science and Technology, 46(6), 978-985.

Duncan, I. J. (1948). Commercial extraction of vegetable oils by means of trichloroethylene. Journal of the American Oil Chemists' Society, 25(8), 277-278.

Dunford, N. T. \& Zhang, M. (2003). Pressurized solvent extraction of wheat germ oil. Food Research International, 36, 905-909.

Ebewele, R. O., Iyayi, A. F. \& Hymore F. K. (2010). Deacidification of high acidic rubber seed oil by reesterification with glycerol. International Journal of the Physical Sciences, 5(6), 841-846.

European Union. (2009). Extraction solvents which may be used during the processing of raw materials, of foodstuffs, of food components or of food ingredients. Official Journal of the European Union, L 141/3 - L 
141/11, 6.6.2009.

FAO. (2010). Food and Agriculture Organization of the United Nations. Food and Nutrition Paper 91 Fats and fatty acids in human nutrition - Report of an expert consultation, Rome, 2010 (E).

Farhoosh, R., Tavassoli-Kafrani, M. H. \& Sharif, A. (2011). Antioxidant activity of sesame, rice bran and bene hull oils and their unsaponifiable matters. European Journal of Lipid Science and Technology, 113, 506-512.

FDA. (2011). Food and Drug Administration. Listing of Food Additive Status Part II. http://www.fda.gov/Food/FoodIngredientsPackaging/FoodAdditives/ucm191033.htm. Acesso em 02 de outubro de 2011.

Fernandez, C. M., Ramos, M. J., Perez, A. \& Rodriguez, J. F. (2010). Production of biodiesel from winery waste: Extraction, refining and transesterification of grape seed oil. Bioresource Technology, 101(18), 70197024.

Ferreira-Dias, S., Valente, D. G. \& Abreu, J. M. F. (2003). Comparison between ethanol and hexane for oil extraction from Quercus suber L. fruits. Grasas y Aceites, 54(4), 378-383.

Firestone, D. (1999) Physical and Chemical Characteristics of Oils, Fats, and Waxes. AOCS Press. Washington D.C.

Follegatti-Romero, L. A., Lanza, M., da Silva, C. A. S., Batista, E. A. C. \& Meirelles, A. J. A. (2010). Mutual solubility of pseudobinary systems containing vegetable oils and anhydrous ethanol from (298.15 to 333.15$) \mathrm{K}$. Journal of Chemical and Engineering Data, 55(8), 2750-2756.

Fonseca, H. \& Regitano-d'Arce, M. A. B. (1993). Aflatoxin removal of peanut meals with aqueous ethanol. Scientia Agricola, 50, 154-156.

Franco, D., Sineiro, J., Pinelo, M. \& Núñez, M. J. (2007). Ethanolic extraction of rosa rubiginosa soluble substances: oil solubility equilibria and kinetic studies. Journal of Food Engineering, 79(1), 150-157.

Franco, D., Sineiro, J. \& Núñez, M. J. (2009). Analysis of variables and modeling of gevuina avellana oil extraction with ethanol near azeotrope conditions. Journal of Food Process Engineering, 32(5), 664-681.

Freitas, S. P., Freitas-Silva, O., Miranda, I. C. \& Coelho, M. A. Z. (2007). Extração e fracionamento simultâneo do óleo da castanha-do-Brasil com etanol. Ciência e Tecnologia de Alimentos, 27, 14-17.

Freitas, S. P. \& Lago, R. C. A. (2007). Equilibrium data for the extraction of coffee and sunflower oils with ethanol. Brazilian Journal of Food Technology, 10(3), 220-224.

Gandhi, A.P., Joshi, K. C., Jha, K., Parihar, V. S., Srivastav, D. C., Raghunadh, P., Kawalkar, J., Jain, S. K. \& Tripathi, R. N. (2003). Studies on alternative solvents for the extraction of oil-1 soybean. International Journal of Food Science and Technology, 38 (3), 369-375.

Gaur, R., Sharma, A., Khare, S. K. \& Gupta, M. N. (2007). A novel process for extraction of edible oils Enzyme assisted three phase partitioning (EATPP). Bioresource Technology, 98, 696-699.

Gingras, L. (2000). Refining of rice bran oil. Inform, 11, 1196-203.

Gonçalves, C. B., Batista, E. \& Meirelles, A. J. A. (2002). Liquid-liquid equilibrium data for the system corn oil + oleic acid + ethanol + water at 298.15 K. Journal of Chemical and Engineering Data, 47, 416-420.

Gonçalves, C. B. \& Meirelles, A. J. A. (2004). Liquid-liquid equilibrium data for the system palm oil plus fatty acids plus ethanol plus water at 318.2 K. Fluid Phase Equilibria, 221(1-2), 139-150.

Greenberg, J., Taylor, D. J., Bond, H. W. \& Sherman, J. F. (1959). Vegetable oil extraction - toxicity of amineextracted soybean meal. Journal of Agricultural and Food Chemistry, 7(8), 573-576.

Hamm, W. (1983). Liquid-liquid extraction in the food industry. In: Lo, T.C., Baird, M.H., Hanson, C. 
Handbook of Solvent Extraction, p.593-597, John Wiley and Sons, New York.

Hammond, E. G., Johnson, L. A., Su, C., Wang, T. \& White, P. J. (2005). Soybean Oil. In: F. Shahidi (editor), Bailey's Industrial Oil and Fat Products, (p 577-653). New Jersey: John Wiley and Sons.

Hanmoungjai, P., Pyle, D. L. \& Niranjan, K. (2002). Enzyme-assisted water-extraction of oil and protein from rice bran. Journal of Chemical Technology and Biotechnology, 77, 771-776.

Harris, W. D., Bishop, F. F., Lyman, C. M. \& Helpert, R. (1947). Isopropanol as solvent for extraction of cottonseed oil. Journal of the American Oil Chemists'Society, 24(11), 370-375.

Harris, W. D., Hayward, J. W. \& Lamb, R. A. (1949). Isopropanol as solvent for extraction of cottonseed oil. Journal of the American Oil Chemists' Society, 26(12), 719-723.

Harris, W. D. \& Hayward, J. W. (1950). Isopropanol as solvent for extraction of cottonseed oil. III. The use of recycling to effect solvent economy. Journal of the American Oil Chemists' Society, 27, 273-275.

Hartman, L. (1971). Tecnologia Moderna da indústria de óleos vegetais. Fundação Centro Tropical de Pesquisas e Tecnologia de Alimentos, 330p., Campinas.

Hierro, M. T. G. \& Santamaria, G. (1992). Supercritical fluid extraction of vegetable and animal fats with CO2 - a mini review. Food Chemistry, 45(3), 189-192.

Hron, R. J., Koltun, S. P. \& Graci Jr., A. V. (1982). Biorenewable solvents for vegetable oil extraction. Journal of the American Oil Chemists' Society, 59(9), 674A-684A.

Hron, R. J. \& Koltun, S. P. (1984). An aqueous ethanol extraction process for cottonseed oil. Journal of the American Oil Chemists' Society, 61(9), 1457-1460.

Hron, R. J. \& Kuk, M. S. (1989). Acetone extracted cottonseed meals without catty odors. Journal of Food Science, 54(4), 1088-1089.

Hron, R. J., Abraham, G., Kuk, M. S. \& Fisher, G. S. (1992). Acidic ethanol extraction of cottonseed. Journal of the American Oil Chemists' Society, 69(9), 951-952.

Hron, R. J., Kuk, M. S., Abraham, G. \& Wan, P. J. (1994). Ethanol extraction of oil, gossypol and aflatoxin from cottonseed. Journal of the American Oil Chemists' Society, 71(4), 417-421.

Hu, W., Wells, J. H., Shin, T. \& Godber, J. S. (1996). Comparison of isopropanol and hexane for extraction of vitamin E and Oryzanols from stabilized rice bran. Journal of the American Oil Chemists' Society, 73(12), 1653-1656.

Ibemesi, J. A. \& Attah, J. C. (1990). Temperature effects on the extraction of rubber and melon seed oils. Journal of the American Oil Chemists' Society, 67(7), 443-445.

IBGE. (2011a). Pesquisa de Orçamentos Familiares 2008-2009. Análise no Consumo Alimentar Pessoal no Brasil.

http://nutrociencia.com.br/upload_files/arquivos/POF_2008_2009_Consumo\%20Alimentar\%20Pessoal.pdf. Acesso em 18 de setembro de 2011.

IBGE. (2011b). Levantamento Sistemático da Produção Agrícola. Confronto das Estimativas Junho/Julho Brasil. http://www.ibge.gov.br/home/estatistica/indicadores/agropecuaria/lspa/lspa_201107_2.shtm. Acesso em 18 de setembro de 2011.

Imsanguan, P., Roaysubtawee, A., Borirak, R., Pongamphai, S., Douglas, S. \& Douglas, P. L. (2008). Extraction of alpha-tocopherol and gamma-oryzanol from rice bran. LWT--Food Science and Technology, 41(8), 1417-1424.

Institute of Medicine. (2005). National Research Council. Dietary reference intakes for energy, carbohydrate, fiber, fat, fatty acids, cholesterol, protein, and amino acids (Macronutrients). Washington, DC: The National 
Academies Press.

IUPAC. (1979). Standard methods for the analysis of oils, fats and derivatives. 6 th edition, part 1 (sections I and II). PAQUOT, C. editor, Pergamon Press.

Ixtaina, V. Y., Martínez, M. L., Spotorno, V., Mateo, C. M., Maestri, D. M., Diehl, B. W. K., Nolasco, S. M. \& Tomás, M. C. (2011). Characterization of chia seed oils obtained by pressing and solvent extraction. Journal of Food Composition and Analysis, 24, 166-174.

Jala, R. C. R., Guo, Z. \& Xu, X. (2011). Separation of FFA from partially hydrogenated soybean oil hydrolysate by means of membrane processing. Journal of the American Oil Chemists' Society, 88(7), 1053-1060.

Jamal, Y. \& Boulanger, B. O. (2010). Separation of oleic acid from soybean oil using mixed-bed resins. Journal of Chemical and Engineering Data, 55(7), 2405-2409.

Johnson, L. A. \& Lusas, E. W. (1983). Comparison of alternative solvents for oils extraction. Journal of the American Oil Chemists' Society, 60(2), 229-242.

Kahlon, T. S. (2009). Rice Bran: production, composition, functionality and food applications, physiological benefits. In: S. S. Cho, \& P. Samuel (editores), Fiber ingredients: food applications and health benefits, (p. $305-$ 321). Boca Raton : CRC Press.

Kaparthi, R. \& Chari, K. S. (1959). Laboratory investigations on the extraction of oil from vegetable oil-cakes with ethanol. Journal of the American Oil Chemists' Society, 36, 81-83.

Karnofsky, G. (1949). The theory of solvent extraction. Journal of the American Oil Chemists' Society, 26, 564569.

Kemper, T. G. (2005). Oil Extraction. In: F. Shahidi (editor), Bailey’s Industrial Oil and Fat Products, (p $57-$ 98). New Jersey: John Wiley and Sons.

Khuri, A. I. \& Cornell, J. A. (1987). Response surface design and analysis. (edited by M. Dekker). New York, USA: ASQC Quality Press.

Kim, S. K., Kim, C. J. \& Cheigh, H. S. (1985). Effect of caustic refining, solvent refining and steam refining on the deacidification and color of rice bran oil. Journal of the American Oil Chemists' Society, 62(10), 14921495 .

Kocatas, B. M., \& Cornell, D. (1954). Holdup and residual saturation of hexane in gravity-drained soybean flake beds. Industrial and Engineering Chemistry, 46(6), 1219-1224.

Krishna, A. G. G. (1993) Influence of viscosity on wax settling and refining loss in rice bran oil. Journal of the American Oil Chemists' Society, 70(9), 895-898.

Kuk, M. S. \& Dowd, M. K. (1998). Supercritical CO2 extraction of rice bran. Journal of the American Oil Chemists' Society, 75(5), 623-628.

Kuk, M. S. \& Hron, R. J. (1998). Cottonseed extraction with new solvent system: Isohexane and alcohol mixtures. Journal of the American Oil Chemists' Society, 75(8), 927-930.

Kuk, M. S., Tetlow, R. \& Dowd, M. K. (2005). Cottonseed extraction with mixtures of acetone and hexane. Journal of the American Oil Chemists' Society, 82(8), 609-612.

Kwiatkowski, J. R. \& Cheryan, M. (2002). Extraction of oil from ground corn using ethanol. Journal of the American Oil Chemists' Society, 79(8), 825-830.

Lago, R. C. A., Szpiz, R. R., Jablonka, F. H., Pereira, D. A. \& Hartman, L. (1985). Extraction and transesterification of vegetable-oils with ethanol. Oleagineux, 40(3), 147-154.

Landucci, G., Nucci, B., Pelagagge, L. \& Nicolella, C. (2011). Hazard assessment of edible oil refining: 
Formation of flammable mixtures in storage tanks. Journal of Food Engineering, 105(1), 105-111.

Latif, S. \& Anwar, F. (2009). Effect of aqueous enzymatic processes on sunflower oil quality. Journal of the American Oil Chemists' Society, 86(4), 393-400.

Leibovitz, Z. \& Ruckenstein, C. (1983). Our experiences in processing maize (corn) germ oil. Journal of the American Oil Chemists' Society, 60, 347A-351A.

Lerma-García, M. J., Herrero-Martínez, J. M., Simó-Alfonso, E. F., Mendonça, C. R. B. \& Ramis-Ramos, G. (2009). Composition, industrial processing and applications of rice bran $\gamma$-oryzanol. Food Chemistry, 115, 389404.

Li, H., Song, C., Wang, N. \& Cao, D. (2011). Optimization of the aqueous enzymatic extraction of wheat germ oil using response surface methodology. Journal of the American Oil Chemists' Society, 88, 809-817.

Liauw, M. Y., Natan, F. A., Widiyanti, P., Ikasari, D., Indraswati, N. \& Soetaredjo, F. E. (2008). Extraction of neem oil (Azadirachta indica A. Juss) using n-hexane and ethanol: studies of oil quality, kinetic and thermodynamic. ARPN Journal of Engineering and Applied Sciences, 3(3), 49-54.

Liberato, S. C. \& Pinheiro-Sant'ana, H. M. (2006). Fortification of industrialized foods with vitamins. Revista de Nutrição, 19(2), 215-231.

Liu, S. X. \& Mamidipally, P. K. (2005). Quality comparison of rice bran oil extracted with d-limonene and hexane. Cereal Chemistry, 82(2), 209-215.

Lloyd, B. J., Siebermorgan, T. J. \& Beers, K. W. (2000). Effects of commercial processing on antioxidants in rice bran. Cereal Chemistry, 77(5), 551-555.

Magne, F. C. \& Skau, E. L. (1953). Phase equilibrium data pertaining to the extraction of cottonseed oil with ethanol and 2-propanol. Journal of the American Oil Chemists'Society, 30, 288-291.

Magnussen, T., Rasmussen, P., \& Fredenslund, A. (1981). UNIFAC parameter table for prediction of liquidliquid equilibria. Industrial and Engineering Chemistry Process Design and Development, 20(2), 331-339.

Mamidipally, P. K. \& Liu, S. X. (2004). First approach on rice bran oil extraction using Limonene. European Journal of Lipid Science and Technology, 106(2), 122-125.

Manan, Z. A., Siang, L. C. \& Mustapa, A. N. (2009). Development of a new process for palm oil refining based on supercritical fluid extraction technology. Industrial \& Engineering Chemistry Research, 48(11), 5420-5426.

Manic, M. S., Najdanovic-Visak, V., da Ponte, M. N. \& Visak, Z. P. (2011). Extraction of free fatty acids from soybean oil using ionic liquids or poly(ethyleneglycol)s. AICHE Journal, 57(5), 1344-1355.

Marcilla, A., Ruiz, F. \& García, A. N. (1975). Liquid-liquid-solid equilibria of the quaternary system waterethanol-acetone-sodium chloride at $25^{\circ} \mathrm{C}$. Fluid Phase Equilibria, 112, 273-289.

McCaskill, D. \& Zhang, F. (1999). Use of rice bran oil in foods. Food Technology, 53(2), 50-52.

Meirelles, A. J. A., Rodrigues, C. E. C., Gonçalves, C. B., Batista, E. A. C. \& Katekawa, M. E. (2009). Processo de Desacidificação de Óleos e Gorduras por Extração Líquido-Líquido e Processo de Purificação de Biodiesel e de Tratamento do Reagente Alcoólico. Patente de Invenção, PI0900869-1A2.

Meziane, S. \& Kadi, H. (2008). Kinetics and thermodynamics of oil extraction from olive cake. Journal of the American Oil Chemists' Society, 85(4), 391-396.

Mishra, A., Gopalakrishna, A.G. \& Prabhakar, J.V. (1988). Factors affecting refining losses in rice (Oryza sativa L.) bran oil. Journal of the American Oil Chemists' Society, 65(10), 1605-1609.

Mohsen-Nia M. \& Khodayari, A. (2008). De-acidification of sunflower oil by solvent extraction: (Liquid plus liquid) equilibrium data at $\mathrm{T}=(303.15$ and 313.15) K. Journal of Chemical Thermodynamics, 40(8), 1325- 
1329.

Mohsen-Nia M., Modarress, H. \& Nabavi, H. R. (2008). Measuring and modeling liquid-liquid equilibria for a soybean oil, oleic acid, ethanol, and water system. Source: Journal of the American Oil Chemists' Society, 85(10), 973-978.

Mohsen-Nia M., Nabavi, H. R. \& Modarress, H. (2007). Liquid-liquid equilibrium for system corn oil plus oleic acid plus ethanol plus water. Physics and Chemistry of Liquids, 45(6), 623-629.

Mohsen-Nia, M. \& Dargahi, M. (2007). Liquid-liquid equilibrium for systems of (corn oil plus oleic acid plus methanol or ethanol) at (303.15 and 313.15) K. Journal of Chemical and Engineering Data, 52(3), 910-914.

Monsoor, M. A., Proctor, A. \& Howard, L. R. (2003). Aqueous extraction, composition, and functional properties of rice bran emulsion. Journal of the American Oil Chemists'Society, 80, 361-365.

Monsoor, M.A. \& Proctor, A. (2005). Tocopherol, tocotrienol, and oryzanol content of rice bran aqueous extracts. Journal of the American Oil Chemists' Society, 82(6), 463-464.

Moreau, R. A. (2005). Corn oil. In: F. Shahidi (editor), Bailey’s Industrial Oil and Fat Products, (p. 149-172). New Jersey: John Wiley and Sons.

Oh, C. H., Kwon, Y. K., Jang, Y. M., Lee, D. S. \& Park, J. S. (2005). Headspace analysis for residual hexane in vegetable oil. Food Science and Biotechnology, 14(4), 456-460.

Oishi, T. \& Prausnitz, J. M. (1978). Estimation of solvent activities in polymer solutions using a groupcontribution method. Industrial \& Engineering Chemistry Process Design and Development, 17(3), 333-339.

Okamoto, K., Hirota, N. \& Terazima, M. (1998). Diffusion of photochemically generated intermediate radicals in water-ethanol mixed solvents. The Journal of Physical Chemistry A, 102, 3447-3454.

Olicer Cereales. (2011). http://www.olicer.com.ar/areacultivos/BR_soja.asp. Acesso em 18 de setembro de 2011.

OMS - Organização Mundial da Saúde. (2010). Population nutrient intake goals for preventing diet-related chronic diseases, Geneva, Switzerland. Disponível em: www.who.int. Acesso em 5 Julho de 2010.

Orthoefer, F. T. (1996). Rice Bran oil: Healthy Lipid Source. Food Technology. 50(12), 62-64.

Orthoefer, F. T. (2005). Rice bran oil. In: F. Shahidi (editor), Bailey’s Industrial Oil and Fat Products, (p. 465 488). New Jersey: John Wiley and Sons.

Ozkal, S. G., Salgin, U. \& Yener, M. E. (2005).Supercritical carbon dioxide extraction of hazelnut oil. Journal of Food Engineering, 69(2), 217-223.

Parrish, D. B. (1980). Determination of vitamin E in foods - a review. CRC Critical Reviews in Food Science and Nutrition, 13(2), 161-187.

Patel, M. \& Naik, S. N. (2004). Gamma-oryzanol from rice bran oil - A review. Journal of Scientific \& Industrial Research, 63, 569-578.

Pina, C. G. \& Meirelles, A. J. A. (2000). Deacidification of corn oil by solvent extraction in a perforated rotating disc column. Journal of the American Oil Chemists' Society, 77(5), 553-559.

Pirola, C., Bianchi, C. L., Boffito, D. C., Carvoli, G. \& Ragaini, V. (2010). Vegetable oil deacidification by amberlyst: study of the catalyst lifetime and a suitable reactor configuration. Industrial \& Engineering Chemistry Research, 49(10), 4601-4606.

Poling, B. E., Prausnitz, J. M. \& O’Connell, J. P. (2001). The Properties of Gases and Liquids. New York: McGraw-Hill.

Proctor, A., Jackson, V. M., Scott, M. \& Clark, P. K. (1994). Rapid equilibrium extraction of rice bran oil at 
ambient-temperature. Journal of the American Oil Chemists Society, 71(11), 1295-1296.

Proctor, A. \& Bowen, D. J. (1996). Ambient-temperature extraction of rice bran oil with hexane and isopropanol. Journal of the American Oil Chemists' Society, 73(6), 811-813.

Przybylski, R. (2005). Flax oil and High linoleic oils. In: F. Shahidi (editor), Bailey's Industrial Oil and Fat Products, (p. 281-301). New Jersey: John Wiley and Sons.

Przybylski, R., Mag, T., Eskin, N. A. M. \& McDonald, B. E. (2005). Canola oil. In: F. Shahidi (editor), Bailey's Industrial Oil and Fat Products, (p. 61-121). New Jersey: John Wiley and Sons.

Rao, R. K.; Krishna, M. G., Zaheer, S. H. \& Arnold, L. K. (1955). Alcoholic extraction of vegetable oils. I. Solubilities of cottonseed, peanut, sesame, and soybean oils in aqueous ethanol. Journal of the American Oil Chemists' Society, 32, 420-423.

Rao, R. K. \& Arnold, L. K. (1956a). Alcoholic extraction of vegetable oils. II. Solubilities of corn, linseed, and tung oils in aqueous ethanol. Journal of the American Oil Chemists' Society, 33, 82-84.

Rao, R. K. \& Arnold, L. K. (1956b). Alcoholic extraction of vegetable oils. III. Solubilities of babassu, coconut, olive, palm, rapessed, and sunflower seed oils in aqueous ethanol. Journal of the American Oil Chemists' Society, 33, 389-391.

Rao, R. K. \& Arnold, L. K. (1957). Alcoholic extraction of vegetable oils .IV. Solubilities of vegetable oils in aqueous 2-propanol. Journal of the American Oil Chemists' Society, 34(8), 401-404.

Rao, R. K. \& Arnold, L. K. (1958). Alcoholic extraction of vegetable oils. V. Pilot plant extraction of cottonseed by aqueous ethanol. Journal of the American Oil Chemists' Society, 35, 277-281.

Regitano-d'Arce, M. A. B. (1985). Ensaios de Extração de Óleo de Girassol (Helianthus annus L.) com Álcool Etílico. Piracicaba, 133 p. Dissertação (Mestre em Ciência e Tecnologia de Alimentos). Escola Superior de Agricultura "Luiz de Queiroz”, Universidade de São Paulo (USP).

Regitano-d'Arce, M. A. B. (1991). Extração de Óleo de Girassol com Etanol: Cinética, ácido clorogênico, Fração insaponificável. São Paulo, 145 p. Tese (Doutor em Ciências dos Alimentos). Faculdade de Ciências Farmacêuticas, Universidade de São Paulo (USP).

Regitano-d'arce, M. A. B., Assis, R. P. \& Lima, U. A. (1994). Functional properties of sunflower seed meal obtained by ethanol extraction. Archivos Latinoamericanos de Nutricion, 44(1), 29-32.

Reipert, E. C. D., Rodrigues, C. E. C. \& Meirelles, A. J. A. (2011). Phase equilibria study of systems composed of refined babassu oil, lauric acid, ethanol, and water at 303.2K. Journal of Chemical Thermodynamics, 43(12), 1784-1790.

Riaz, M. N. (2005). Extrusion processing of oilseed meals for food and feed production. In: F. Shahidi (editor), Bailey's Industrial Oil and Fat Products, (p. 533-572). New Jersey: John Wiley and Sons.

Ribeiro, B. D., Nascimento, R. F., Barreto, D. W., Coelho, M. A. Z. \& Freitas, S. P. (2010). An ethanol-based process to simultaneously extract and fractionate carotenoids from mauritia flexuosa pulp. Revista Brasileira de Fruticultura, 32(3), 657-663.

Rittner, H. (1984). Conditioning of oil-bearing materials for solvent extraction by extrusion. Journal of the American Oil Chemist's Society, 61(7), 1200-1203.

Rittner, H. (1992). Extraction of vegetable oils with ethyl alcohol. Oléagineux, 47(1), 29-42.

Rodrigues, C. E. C, Antoniassi, R. \& Meirelles, A. J. A. (2003). Equilibrium data for the system rice bran oil + fatty acids + ethanol + water at 298.2 K. Journal of Chemical Engineering Data, 48, 367-373.

Rodrigues, C. E. C. (2004). Desacidificação do Óleo de Farelo de Arroz por Extração Líquido-líquido. Campinas, 221 p. Tese (Doutor em Engenharia de Alimentos). Faculdade de Engenharia de Alimentos, 
Universidade Estadual de Campinas (UNICAMP).

Rodrigues, C. E. C., Pessoa Filho, P. A. \& Meirelles, A. J. A. (2004). Phase equilibrium for the system rice bran oil + fatty acids + ethanol + water + gamma-oryzanol + tocols. Fluid Phase Equilibria, 216, 271-283.

Rodrigues, C. E. C., Reipert, E. C. C. D., Souza, A. F., Pessoa Filho, P. A. \& Meirelles, A. J. A. (2005a). Equilibrium data for systems composed by cottonseed oil + commercial linoleic acid + ethanol + water + tocopherols at 298.2 K. Fluid Phase Equilibria, 238(2), 193-203.

Rodrigues, C. E. C., Silva, F. A., Marsaioli Jr., A. \& Meirelles, A. J. A. (2005b). Deacidification of Brazil nut and macadamia nut oils by solvent extraction-liquid-liquid equilibrium data at $298.2 \mathrm{~K}$. Journal of Chemical Engineering Data, 50, 517-523.

Rodrigues, C. E. C., Filipini, A. \& Meirelles, A. J. A. (2006a). Phase equilibrium for systems composed by high unsaturated vegetable oils + linoleic acid + ethanol + water at 298.2 K. Journal of Chemical and Engineering Data, 51, 15-21.

Rodrigues, C. E. C., Onoyama, M. M. \& Meirelles, A. J. A. (2006b). Optimization of the rice bran oil deacidification process by liquid - liquid extraction. Journal of Food Engineering, 73, 370-378.

Rodrigues, C. E. C., Gonçalves, C. B., Batista, E. A. C., Meirelles, A. J. A. (2007a). Deacidification of vegetable oils by solvent extraction. Recent patents in engineering, 1, 95-102.

Rodrigues, C. E. C., Peixoto, E. C. D. \& Meirelles, A. J. A. (2007b). Phase equilibrium for systems composed by refined soybean oil + commercial linoleic acid + ethanol +water, at 323.2K. Fluid Phase Equilibria, 261, $122-128$.

Rodrigues, C. E. C. \& Meirelles, A. J. A. (2008). Extraction of free fatty acids from peanut oil and avocado seed oil: Liquid-liquid equilibrium data at 298.2 K. Journal of Chemical and Engineering Data, 53(8), 16981704.

Rosenthal, A., Pyle, D. L. \& Niranjan, K. (1996). Aqueous and enzymatic processes for edible oil extraction. Enzyme and Microbial Technology, 19, 402-420.

Sanaiotti, G., Coimbra, J. S. R., Gomes, J. C. \& Minim, L. A. (2008). Liquid-liquid equilibrium for systems composed of grape seed oil plus oleic acid plus ethanol plus water at (283.2, 290. 7, and 298.2) K. Journal of Chemical and Engineering Data, 53(7), 1492-1497.

Sanaiotti, G., da Silva, C. A. S., Parreira, A. G., Totola, M. R., Meirelles, A. J. A. \& Batista, E. A. C. (2010). Densities, viscosities, interfacial tensions, and liquid-liquid equilibrium data for systems composed of soybean oil plus commercial linoleic acid plus ethanol + water at 298.2 K. Journal of Chemical and Engineering Data, 55(11), 5237-5245.

Sato, M. \& Ito, C. (1932). Method of Extracting Fatty Oil. Patente americana 1892366.

Saxena, D. K., Shrama, S. K. \& Sambi, S. S. (2011). Kinetics and thermodynamics of cottonseed oil extraction. Grasas y Aceites, 62(2), 198-205.

Seetharamaiah, G. S. \& Prabhakar, J. V. (1986). $\gamma$-Orizanol content of indian rice bran oil and its extraction from soapstock. Journal of Food Science and Technology, 23, 270-273.

Sengupta, R. \& Bhattacharyya, D. K. (1996). A comparative study between biorefining combined with other processes and physical. Journal of the American Oil Chemists' Society, 69, 1146-1149.

Seth, S., Agrawal, Y. C., Ghosh, P. K. \& Jayas, D. S. (2010). Effect of moisture content on the quality of soybean oil and meal extracted by isopropyl alcohol and hexane. Food and Bioprocess Technology, 3, 121-127.

Shen, Z. P., Palmer, M. V., Ting, S. S. T. \& Fairclough, R. J. (1996). Pilot scale extraction of rice bran oil with dense carbon dioxide. Journal of Agricultural and Food Chemistry, 44(10), 3033-3039.

Silva, A. E., Lanza, M., Batista, E. A. C., Rodrigues, A. M. C., Meirelles, A. J. A. \& Silva, L. H. M. (2011). 
Liquid-liquid equilibrium data for systems containing palm oil fractions plus fatty acids plus ethanol plus water. Journal of Chemical and Engineering Data, 56(5), 1892-1898.

Silva, C. A. S., Sanaiotti, G., Lanza, M., Follegatti-Romero, L. A., Meirelles, A. J. A. \& Batista, E. A. C. (2010a). Mutual solubility for systems composed of vegetable oil + ethanol + water at different temperatures. Journal of Chemical and Engineering Data, 55, 440-447.

Silva, C. A. S., Sanaiotti, G., Lanza, M., Meirelles, A. J. A. \& Batista, E. A. C. (2010b). Liquid-liquid equilibrium data for systems containing Jatropha curcas oil plus oleic acid plus anhydrous ethanol plus water at (288.15 to 318.15) K. Journal of Chemical and Engineering Data, 55, 2416-2423.

Silva, L. H. M., Coimbra, J. S. R. \& Meirelles, A. J. A. (1997). Equilibrium phase behavior of poly(ethylene glycol $)+$ potassium phosphate + water two-phase systems at various $\mathrm{pH}$ and temperatures. Journal of Chemical and Engineering Data, 42, 398-401.

Silva, M. T. C., Turatti, J. M. (1991). Extração de óleo de soja com etanol. Coletânea Ital, 21(1), 73-89.

Sineiro, J., Domínguez, H., Núñez, M. J. \& Lema, J. M. (1998). Ethanolic extraction of sunflower oil in a pulsing extractor. Journal of the American Oil Chemists' Society, 75(6), 753-754.

Sookwong, P., Nakagawa, K., Yamaguchi, Y., Miyazawa, T., Kato, S., Kimura, F. \& Miyazawa, T. (2010). Tocotrienol distribution in foods: estimation of daily tocotrienol intake of japanese population. Journal of Agricultural and Food Chemistry, 58, 3350-3355.

Sovová, H., Zarevúcka, M., Vacek, M. \& Stránský, K. (2001). Solubility of two vegetable oils in supercritical CO2. Journal of Supercritical Fluids, 20, 15-28.

Soystats. (2011). http://www.soystats.com/2011/Default-frames.htm. Acesso em 23 de setembro de 2011.

Stahl, E., Schutz, E. \& Mangold, H. K. (1980). Extraction of seed oils with liquid and supercritical CO2. Journal of Agricultural and Food Chemistry, 28, 1153.

Stragevitch, L. \& d'Avila, S. G. (1997). Application of a generalized maximum likelihood method in the reduction of multicomponent liquid- liquid equilibrium data. Brazilian Journal of Chemical Engineering, 14, 41-52.

Survase, S. A., Jurgens, G., van Heiningen, A. \& Granstrom, T. (2011). Continuous production of isopropanol and butanol using Clostridium beijerinckii DSM 6423. Applied Microbiology and Biotechnology, 91(5), 13051313.

Swern, D. (1964). Bailey’s Industrial Oil and Fat products. John Wiley and Sons. Terceira edição.

Takeuchi, T. M., Pereira, C. G., Braga, M. E. M., Maróstica, M. R., Leal, P. F. \& Meireles, M. A. A. (2009). Low-pressure solvent extraction (Solid-liquid extraction, microwave assisted, and Ultrasound assisted) from Condimentary plants. Extracting Bioactive Compounds for Food Products. Meireles, M. A. A. (Ed.). Boca Raton: CRC Press.

Taniguki, M., Tsuji, T., Shibata, M. \& Kobayashi, T. (1985). Extraction of wheat germ with supercritical carbon dioxide. Agricultural Biological Chemistry, 49, 2367.

Thomopoulos, C. (1971). Méthode de desacidification des huiles par solvant sélectif. Revue Française des Corps Gras, 18(3), 143-150.

Tominaga, T. \& Matsumoto, S. (1990). Diffusion of polar and nonpolar molecules in water and ethanol. Bulletin of the Chemical Society of Japan, 63, 533-537.

Topallar, H. \& Geçgel, U. (2000). Kinetics and thermodynamics of oil extraction from sunflower seeds in the presence of aqueous acidic hexane solutions. Turkish Journal of Chemistry, 24(3), 247-253.

UFRGS. (2011). Universidade Federal do Rio Grande do Sul. 
http://www.ufrgs.br/alimentus/terradearroz/grao/gr_divisao.htm). Acesso em 23 de setembro de 2011.

UNICA. (2011). União da Indústria de Cana-de-açúcar. http://www.unica.com.br/dadosCotacao/estatistica/. Acesso em 12 de setembro de 2011.

USDA. (2011a). United States Department of Agriculture. Foreign Agricultural Service. Table 09: Soybean Oil: World Supply and Distribution. 9/12/2011. http://www.fas.usda.gov/wap/current/default.asp. Acesso em 12 de setembro de 2011.

USDA. (2011b). United States Department of Agriculture. Foreign Agricultural Service. Table 09 Rice Area, Yield, and Production. World and Selected Countries and Regions. 9/12/2011. http://www.fas.usda.gov/wap/current/default.asp. Acesso em 12 de setembro de 2011.

Vaccarino, C., Vaccarino, G. \& Marina, V. (1961). A new industrial process for cottonseed. Journal of the American Oil Chemists' Society, 38(3), 143-147.

Van Hoed, V., Ali, C. B., Slah, M. \& Verhe', R. (2010). Quality differences between pre-pressed and solvent extracted rapeseed oil. European Journal of Lipid Science and Technology, 112, 1241-1247.

Vaszquez L., Hurtado-Benavides, A. M., Reglero, G., Fornari, T., Ibanez, E. \& Senorans, F. J. (2009). Deacidification of olive oil by countercurrent supercritical carbon dioxide extraction: Experimental and thermodynamic modeling. Journal of Food Engineering, 90(4), 463-470.

Velásquez-Meléndez, G., Martins, I. S., Cervato, A. M., Fornés, N. S. \& Marucci, M. F. N. (1997). Consumo alimentar de vitaminas e minerais em adultos residentes em área metropolitana de São Paulo, Brasil. Journal of Public Health, 31(2), 157-162.

Wakelyn, P. J. \& Wan, P. J. (2006). Solvent extraction to obtain edible oil products. In: C. C. Akoh (editor), Handbook of Functional Lipids, (p. 89-131). Boca Raton: CRC Press.

Wan, P. J., Hron, R. J., Dowd, M. K., Kuk, M. S. \& Conkerton, E. J. (1995). Alternative hydrocarbon solvents for cottonseed extraction - plant trials. Journal of the American Oil Chemists' Society, 72(6), 661-664.

Wang, Y., Wang, Z., Cheng, S. \& Han, F. (2008). Aqueous enzymatic extraction of oil and protein hydrolysates from peanut. Food Science and Technology Research, 14(6), 533 - 540.

Williams, M. A. (2005). Recovery of oils and fats from oilseeds and fatty materials. In: F. Shahidi (editor), Bailey's Industrial Oil and Fat Products, (p. 99-189). New Jersey: John Wiley and Sons.

Wisniak, J., Hillet, J. \& Katz, O. (1987). Hold-up and extraction characteristics of jojoba meal. Journal of the American Oil Chemists' Society, 64(9), 1352-1354.

Xu, Z. \& Godber, J. S. (2000). Comparison of supercritical fluid and solvent extraction methods in extracting $\gamma$ oryzanol from rice bran. Journal of the American Oil Chemists' Society, 77(5), 547-551.

Zhang, F., Rhee, K. C. \& Koseoglu, S. S. (2002a). Isopropyl alcohol extraction of cottonseed collets: Efficiency and performance. Journal of Food Lipids, 9(2), 147-160.

Zhang, F., Rhee, K. C. \& Koseoglu, S. S. (2002b). Isopropyl alcohol extraction of cottonseed collets: Crude oil composition. Journal of Food Lipids, 9(2), 161-173.

Zhang, S. B., Lu, Q. Y., Yang, H. \& Shuai Wang, Y. L. (2011). Aqueous enzymatic extraction of oil and protein hydrolysates from roasted peanut seeds. Journal of the American Oil Chemists' Society, 88, 727-732.

Zigoneanu, I. G., Wilhams, L., Xu, Z. \& Sabliov, C. M. (2008). Determination of antioxidant components in rice bran oil extracted by microwave-assisted method. Bioresource Technology, 99(11), 4910-4918. 